

\section{vegetação, \\ temperatura de superfície e morfologia urbana um retrato da região metropolitana de São Paulo}

Tese apresentada à Faculdade de Arquitetura e Urbanismo da Universidade de São Paulo para obtenção do título de Doutor em Arquitetura e Urbanismo 
AUTORIZO A REPRODUÇÃO E DIVULGAÇÃO TOTAL OU PARCIAL DESTE TRABALHO, POR QUALQUER MEIO CONVENCIONAL OU ELETRÔNICO, PARA FINS DE ESTUDO E PESQUISA, DESDE QUE CITADA A FONTE.

email: luciana.swf@gmail.com

EXEMPLAR REVISADO E ALTERADO EM RELAÇÃO À VERSÃO ORIGINAL, SOB RESPONSABILIDADE DO AUTOR E ANUÊNCIA DO ORIENTADOR.

O original se encontra disponível na sede do programa.

São Paulo, 24 de Julho de 2019.

Catalogação na Publicação

Serviço Técnico de Biblioteca

Faculdade de Arquitetura e Urbanismo da Universidade de São Paulo

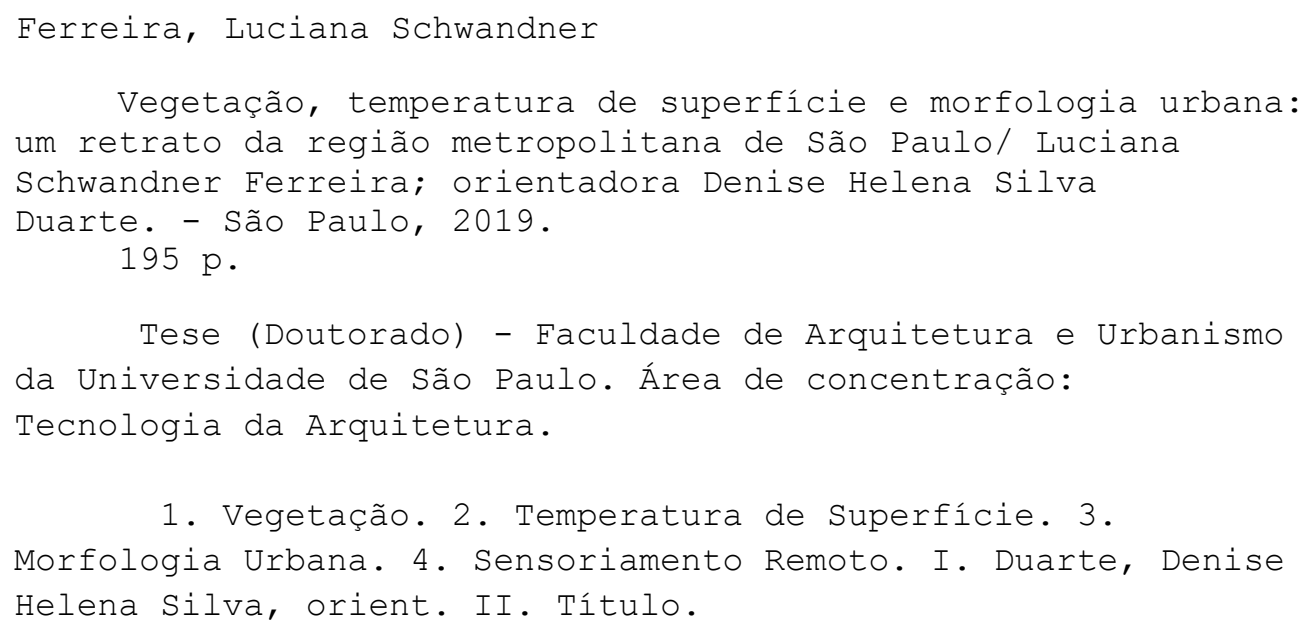

Elaborada eletronicamente através do formulário disponível em: 〈http://www.fau.usp.br/fichacatalografica/〉 
FERREIRA, Luciana Schwandner. Vegetação, temperatura de superfície e morfologia urbana: um retrato da região metropolitana de São Paulo. 2019. 195p. Tese (Doutorado) - Faculdade de Arquitetura e Urbanismo, Universidade de São Paulo, São Paulo, 2019.

Banca examinadora

Prof. Dr.

Instituição:

Julgamento

Prof. Dr.

Instituição:

Julgamento

Prof. Dr.

Instituição:

Julgamento

Prof. Dr.

Instituição:

Julgamento

Prof. Dr.

Instituição:

Julgamento

Aprovado em: 



\section{Agradecimentos}

A realização de uma tese é fruto da colaboração direta e indireta de muitas pessoas e instituições.

Primeiramente agradeço à Fundação de Amparo à Pesquisa do Estado de São Paulo (FAPESP) pelo apoio financeiro (2015/17360-5), sem o qual este trabalho não seria possível.

À Universidade de São Paulo, que nos últimos dezessete anos, proporcionou-me o convívio com professores, colegas e funcionários do mais alto nível intelectual e humano, que me moldaram como profissional e como pessoa.

À minha orientadora, professora Denise Duarte, pela orientação cuidadosa e carinhosa, pela confiança em mim depositada e pelo seu exemplo de ética, seriedade e amor à pesquisa e ao ensino.

Aos professores Humberto Ribeiro da Rocha e Teodoro Isnard Ribeiro de Almeida pelas valiosas contribuições na banca de qualificação e em diversos momentos deste trabalho.

Aos professores Demóstenes Ferreira da Silva Filho, Marcelo Giacaglia, Humberto Ribeiro da Rocha, Maria Lúcia Refinetti, Eugênio Queiroga, Alessandra Prata-Shimomura e Anderson Targino, pelas contribuições durante as disciplinas cursadas e no desenvolvimento deste trabalho.

À Seção Técnica de Geoinformação e Produção de Bases Digitais (CESAD-FAUUSP), em especial ao Ricardo Nader e ao Laboratório de Informática Geológica do Instituto de Geociências (IGC-USP), pelo suporte técnico, especialmente no início da pesquisa.

Ao Centro de Estatística Aplicada (CEA-IME-USP), à Professora Dra Chang Chiann e ao Vinícius Soares Martins Alves pelo suporte estatístico.

Ao Fabien Wagner, do Instituto Nacional de Pesquisas Espaciais (INPE), pelas orientações em relação à utilização do programa $R$.

Ao Dr. lain Stewart, do Global Cities Institute, da Universidade de Toronto, pelas ricas contribuições com a classificação Local Climate Zones. 
À Helia Pereira, à Rosélia Ikeda e à Priscilla Cerqueira, da Secretaria do Verde e do Meio Ambiente do Município de São Paulo e ao Roberto Rüsche, da Empresa Paulista de Planejamento Metropolitano (EMPLASA), pela cessão de informações.

Aos professores e colegas da FAU e do LABAUT, em especial à Alessandra Prata, Leonardo Monteiro, Ranny Michalsky, Ranieri Higa, Carolina Alves, Carolina Gusson, Cida Ghosn, Fernanda Tsuda, Paula Shinzato, Martina Pacifici, Mayumi Hirye e às alunas de graduação Alice Schiavinato, Bianca Bonachela e Caroline Viana, pela convivência, pela amizade e pelas contribuições diretas e indiretas a este trabalho.

Aos amigos que acompanharam o desenvolvimento deste trabalho, em especial ao Diego, Alessandra, Clarissa, Giovanna e Thais. E à Aninha e à Biju que mesmo longe estiveram perto.

À Oficinalab por me acolher nas últimas semanas de elaboração desta tese.

À minha família, pelo apoio e carinho. Em especial aos meus pais, Ubiratã e Maria do Carmo, pelo amor, amizade, suporte e incentivos constantes. Ao meu irmão, João Paulo, pelo apoio e por seu maior presente, o Vicente. À Zazinha pelo carinho. Ao meu tio, Ubirajara, pela ajuda estatística. Novamente à minha mãe, pela ajuda na revisão da tese. $\mathrm{E}$ ao Alex, pela elaboração da capa, pela companhia de vida, pela amizade, carinho e paciência e por estar ao meu lado em todos os momentos. 


\section{Resumo}

O objetivo desta pesquisa é examinar a relação entre vegetação, temperatura de superfície e morfologia urbana na Região Metropolitana de São Paulo, tanto espacial quanto temporalmente. Para tanto utilizam-se índices de vegetação e imagens termais diurnas e noturnas do satélite Aqua-MODIS de 2002 a 2017, além de mapeamento da morfologia urbana de acordo com o conceito de local climate zones. As hipóteses que norteiam o trabalho são as de que áreas com a presença de vegetação apresentam menor temperatura superficial ao longo de todo o ano e que a supressão da vegetação acarreta aumento de temperatura superficial. Os resultados evidenciam que as áreas mais urbanizadas apresentam temperatura de superfície diurna e noturna superior às áreas menos urbanizadas, sendo que a área urbanizada não se apresenta homogênea: áreas com maiores índices de vegetação e/ou edifícios mais altos apresentam temperatura de superfície inferior a outras tipologias urbanas no período diurno e áreas com edifícios altos e índices de vegetação baixos apresentam temperatura superficial noturna mais elevada, característica compatível com o padrão de ilha de calor de superfície. As áreas que apresentaram perdas extensas de vegetação e intervenções urbanas, como a implantação de pavimentação, apresentaram aumento de temperatura superficial, sendo os resultados temporais fortemente dependentes da escala de análise. A correlação entre a temperatura de superfície e os índices de vegetação é alta e negativa para todo o período analisado, mantendo-se elevada tanto nas estações com temperaturas superficiais acima da média do período como naquelas com precipitação abaixo da média do período, indicando o papel da vegetação tanto na atenuação das temperaturas

superficiais na RMSP quanto sua possível resiliência às situações extremas de temperaturas elevadas e baixa precipitação.

Palavras-chave: Vegetação; Temperatura de Superfície, Morfologia Urbana; Sensoriamento Remoto. 


\section{Abstract}

VEGETATION, SURFACE TEMPERATURE AND URBAN MORPHOLOGY. A PORTRAIT OF THE SÃO PAULO METROPOLITAN REGION.

The objective of this research is to examine the relationship between vegetation, surface temperature and urban morphology in the Metropolitan Region of São Paulo (MRSP), both in space and time. Vegetation indices and daytime and nighttime thermal images of the Aqua-MODIS satellite from 2002 to 2017 are used, as well as mapping of urban morphology according to the local climate zones concept. The hypotheses that guide this research are that areas with the presence of vegetation present a lower surface temperature throughout the year and that the suppression of vegetation leads to an increase in surface temperature. Results show higher daytime and nighttime surface temperature at the urbanized areas, compared to their less urbanized surroundings, however, the urbanized area is not homogeneous: Areas with higher vegetation indexes and / or higher buildings have lower surface temperatures compared to other urban typologies in the daytime period, and areas with high buildings and low vegetation indexes have higher nighttime surface temperature, a feature compatible with the surface heat island pattern. The areas that presented extensive vegetation losses and urban interventions, such as pavement, showed an increase in surface temperature, with temporal results strongly depending on the scale of analysis. The correlation between surface temperature and vegetation indices is high and negative for the whole period analyzed. The correlation remains high in seasons with surface temperatures above the average and those with precipitation below the average, indicating the role of vegetation in the attenuation of the surface temperatures in the MRSP and also its possible resilience to extreme events of high temperatures and low precipitation.

Key-words: Vegetation; Surface Temperature, Urban Morphology; Remote sensing. 


\section{Lista de figuras}

Figura 1. Escalas climáticas e camadas verticais em áreas urbanas. $P B L, U B L$ e $U C L$

Figura 2. Descrição esquemática da variação das temperaturas do $\operatorname{ar}\left(T_{a}\right)$ e da superfície $\left(T_{0}\right)$ em uma cidade plana. (a) mapa de isotermas mostrando padrões típicos da ilha de calor urbana. (b) variação diurna e noturna das temperaturas do $\operatorname{ar}\left(\mathrm{T}_{\mathrm{a}}\right)$ e da superfície $\left(\mathrm{T}_{0}\right)$ ao longo da seção $\mathrm{A}-\mathrm{B}$............................................. 32

Figura 3. Relação entre a média da $T_{\text {sup }}$ e FVC para o dia 07/Agosto/2013. ................................................... 34

Figura 4. Relação entre a média da $T_{\text {sup }}$ e FVC para o dia 24/Setembro/2013 …........................................... 34

Figura 5. Interações radiativas e energéticas do microclima urbano diurnas ( $A$ e B) e noturnas (C e D) para uma rua sem vegetação ( $A$ e C) e com vegetação (B e D).

Figura 6. Parque do Trote, São Paulo. Raleamento das copas do conjunto arbóreo localizado à direita da imagem devido à implantação de piso ao redor das árvores

Figura 7. Imagem termal do Parque Tenente Siqueira Campos - Trianon (São Paulo) em primeiro plano e edifícios ao fundo. Câmera termográfica digital FLIR i40.

Figura 8. Imagem termal de um veículo estacionado na Rua Peixoto Gomide (São Paulo). Câmera termográfica digital FLIR i40

Figura 9. Imagem termal de alta resolução captada por sensor acoplado em aeronave. Resolução espacial $0,5 \mathrm{~m}$

Figura 10. Imagem termal da RMSP captada pelo sensor MODIS acoplado ao satélite Aqua. Resolução espaciall 250m.

Figura 11. Espectro eletromagnético

Figura 12. Interação da radiação medida por um satélite com diferentes materiais e com a atmosfera durante o dia.......

Figura 13. Interação da radiação medida por um satélite com diferentes materiais e com a atmosfera durante a noite.

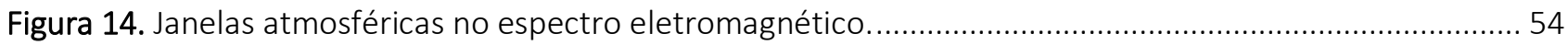

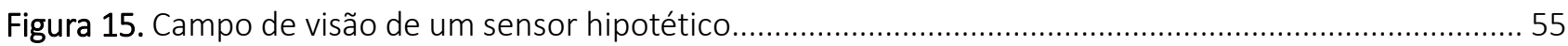

Figura 16. Percentual de refletância de diferentes materiais urbanos medidas em laboratório ...................... 60

Figura 17. Curva espectral típica de uma folha verde

Figura 18. Refletância espectral de quatro folhas diferentes obtidas de uma mesma árvore sadia (Liquidambar styraciflua $L$ )

Figura 19. Influência da umidade na refletância espectral de uma folha de milho .......................................... 61

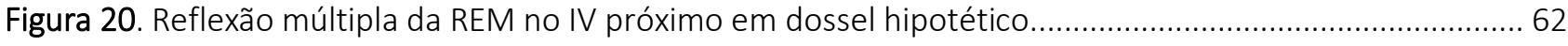

Figura 21. Fatores de refletância em dosséis hipotéticos vs. camadas de folhas......

Figura 22. Relação entre a refletância do IV próximo e do vermelho para (a) diferentes áreas de uma zona agrícola e (b) para diferentes fases do ciclo fenológico

Figura 23. Mapas de UOS e LCZ da RMSP. [1] Mapa LCZ [2] Mapa QUAPA [3] Mapa EMPLASA

Figura 24. Comparação entre os mapas. Bairro do Pacaembu, São Paulo. [1] Imagem Google Earth [2] Mapa LCZ [3] Mapa QUAPA [4] Mapa EMPLASA.

Figura 25. Comparação entre os mapas. Bairro de Pinheiros, São Paulo. [1] Imagem Google Earth [2] Mapa LCZ [3] Mapa QUAPA [4] Mapa EMPLASA. 
Figura 26. Comparação entre os mapas. Município de Suzano. [1] Imagem Google Earth [2] Mapa LCZ [3]

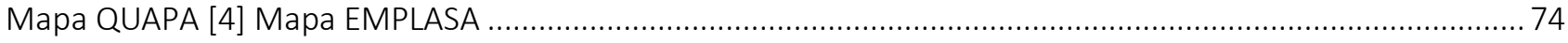

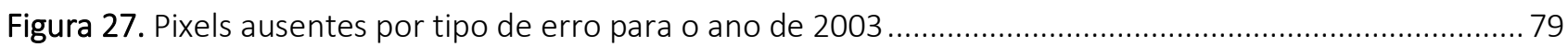

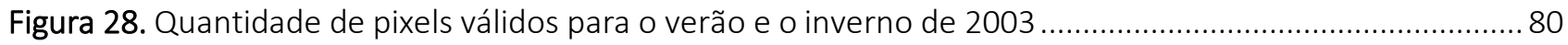

Figura 29. Divisão das estações seca e chuvosa de acordo com o dia do ano (DOY)........................................ 82

Figura 30. Cenas com 90\% (1), 70\% (2) e 50\% (3) de dados válidos para dias distintos................................ 82

Figura 31. T Tup diurna média da estação chuvosa 2003/04 considerando-se apenas pixels com mais de $50 \%$ de

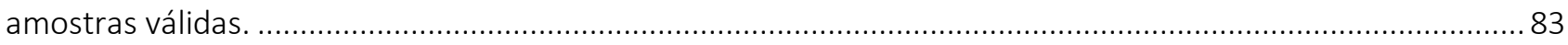

Figura 32. Esquema do processamento executado para o produto termal (MYD11A2) .............................. 85

Figura 33. Esquema do processamento executado para o produto índices de vegetação (MYD13Q1)............ 85

Figura 34. Diagrama do processamento executado. Análise espacial, imagens médias. ............................... 89

Figura 35. Diagrama do processamento executado. Análise espacial, imagens médias e LCZ.........................90

Figura 36. Análise de tendência. Diagrama explicativo: ajuste da reta de regressão linear..............................92

Figura 37. Análise de tendência. Diagrama explicativo: intervalo de confiança (significância estatística)......... 93

Figura 38. Análise de tendência. Diagrama explicativo: significância prática................................................. 94

Figura 39. Divisão Político Administrativa da Região Metropolitana de São Paulo e área urbanizada ................96

Figura 40. Mapa com a classificação LCZ de 2002. Resolução espacial: 100m ..............................................98

Figura 41. Rodovia Castello Branco e trecho Oeste do Rodoanel Mario Covas em obras. 1) Imagem IKONOS

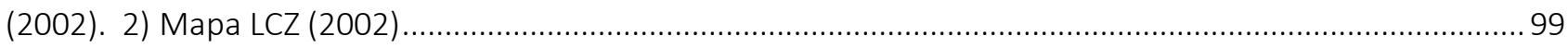

Figura 42. Mapa com a classificação LCZ de 2010. Resolução espacial: 100m ............................................100

Figura 43. 1) Imagem Ortorretificada (2010/2011). 2) Mapa LCZ (2010). Marginal Pinheiros e bairros da zona

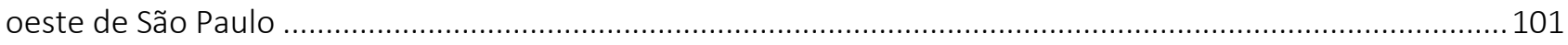

Figura 44. 1) Imagem Ortorretificada (2010/2011). 2) Mapa LCZ (2010). Salesópolis ................................... 101

Figura 45. Mapa com a classificação LCZ de 2017. Resolução espacial: 100m ...............................................102

Figura 46. 1) Imagem Google Earth (2017). 2) Mapa LCZ (2017). Trecho das Marginais Tietê e Pinheiros ..... 103

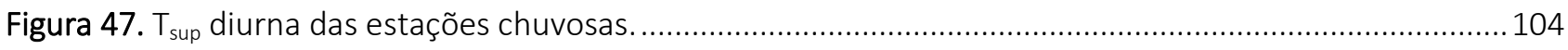

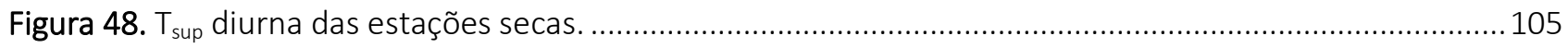

Figura 49. Áreas urbanizadas com $T_{\text {sup }}$ diurna inferior ao entorno. Estação Seca 2017. ............................... 107

Figura 50. Diferença da $T_{\text {sup }}$ diurna de cada pixel em relação à temperatura média da RMSP. Estação chuvosa.

Figura 51. Diferença da $T_{\text {sup }}$ diurna de cada pixel em relação à temperatura média da RMSP. Estação Seca. 109

Figura 52. Sobreposição da imagem de diferença da $T_{\text {sup }}$ diurna de cada pixel em relação à temperatura média da RMSP na Estação Seca 2017 com o mapa LCZ 2017.........................................................................110

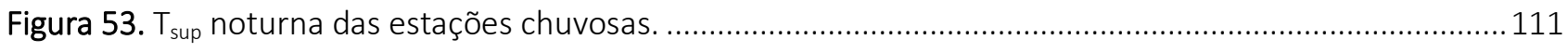

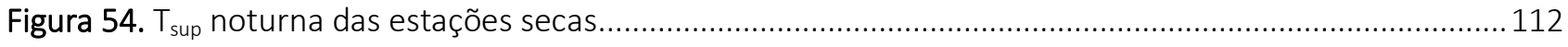

Figura 55. Sobreposição do mapa de $T_{\text {sup }}$ noturna da estação seca de 2017 com o mapa LCZ 2017...............113

Figura 56. Diferença da $T_{\text {sup }}$ noturna de cada pixel em relação à temperatura média da RMSP. Estação

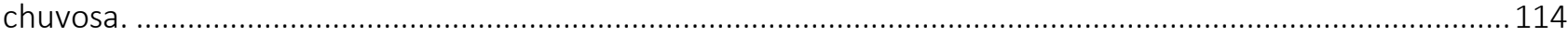

Figura 57. Diferença da $T_{\text {sup }}$ noturna de cada pixel em relação à temperatura média da RMSP. Estação Seca.

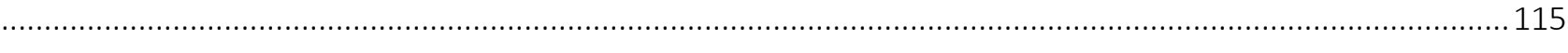

Figura 58. Imagem média diurna de todas as estações chuvosas................................................................... 116

Figura 59. Imagem média diurna de todas as estações secas ........................................................................ 117 
Figura 60. Imagem média noturna de todas as estações chuvosas............................................................ 117

Figura 61. Imagem média noturna de todas as estações secas .................................................................... 118

Figura 62. $T_{\text {sup }}$ diurna e noturna por LCZ 2002. Estação Chuvosa 2002/2003 ….......................................... 120

Figura 63. $T_{\text {sup }}$ diurna e noturna por LCZ 2002. Estação Seca 2003 …............................................................ 120

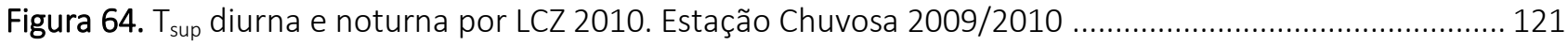

Figura 65. Tsup diurna e noturna por LCZ 2010. Estação Seca 2010 …........................................................... 121

Figura 66. Tsup diurna e noturna por LCZ 2017. Estação Chuvosa 2016/2017 ….......................................... 122

Figura 67. Tsup diurna e noturna por LCZ 2017. Estação Seca 2017........................................................... 122

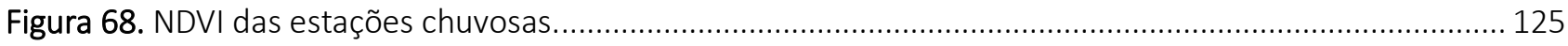

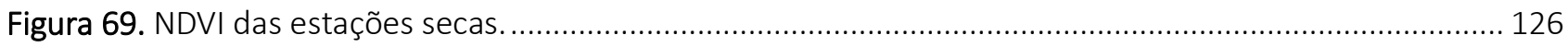

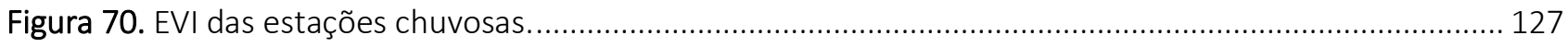

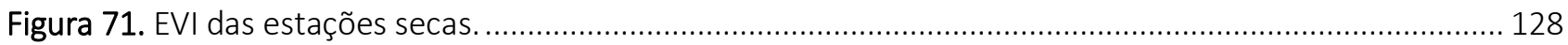

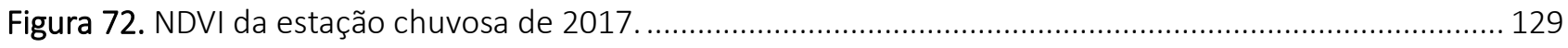

Figura 73. NDVI da estação chuvosa de 2017 sobre mapa LCZ de 2017................................................... 130

Figura 74. NDVI por LCZ 2002. Estação Chuvosa 2002/2003................................................................... 131

Figura 75. NDVI por LCZ 2002. Estação Seca 2003. ............................................................................. 131

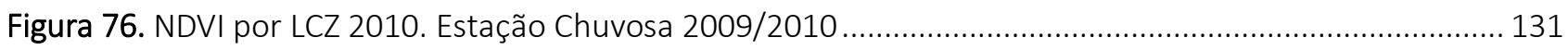

Figura 77. NDVI por LCZ 2010. Estação Seca 2010. ............................................................................. 131

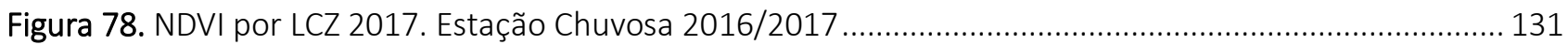

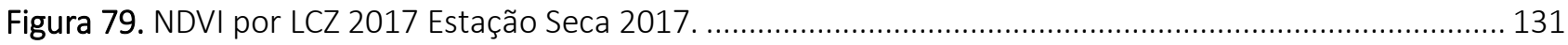

Figura 80. EVI por LCZ 2002. Estação Chuvosa 2002/2003.......................................................................... 132

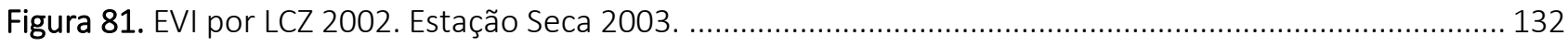

Figura 82. EVI por LCZ 2010. Estação Chuvosa 2009/2010 …....................................................................... 132

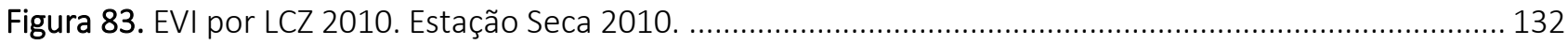

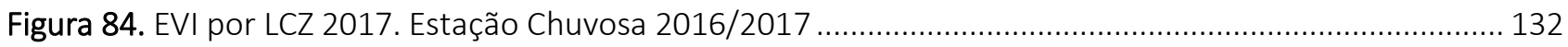

Figura 85. EVI por LCZ 2017 Estação Seca 2017. ................................................................................. 132

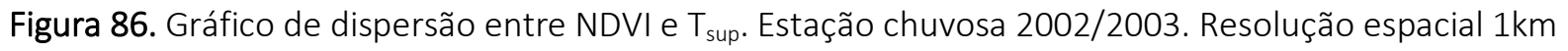
utilizando todos os dados disponíveis. A) Temperatura superficial diurna. B) Temperatura superficial noturna.

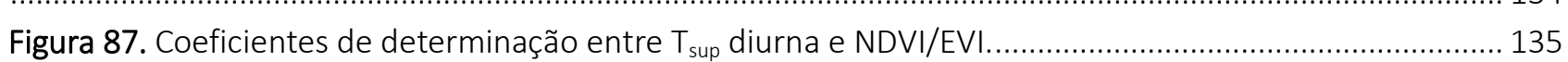

Figura 88. Coeficientes de determinação entre $T_{\text {sup }}$ noturna e NDVI/EVI. ....................................................... 135

Figura 89. Alterações de vegetação entre 2002 e 2010 ................................................................................ 137

Figura 90. Ganho de vegetação entre 2002 e 2010 em Guararema. 1) Mapa de detecção de mudanças. 2) Imagem IKONOS 2002. 3) Ortofoto 2010/2011.................................................................................... 138

Figura 91. Perda de vegetação entre 2002 e 2010 em Cajamar e Caieiras. 1) Mapa de detecção de mudanças.

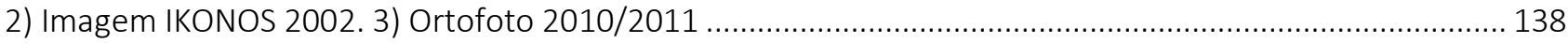

Figura 92. Alterações de vegetação entre 2002 e 2010 na zona sul de São Paulo. 1) Mapa de detecção de mudanças. 2) Imagem IKONOS 2002. 3) Ortofoto 2010/2011 .................................................................. 139

Figura 93. Alterações de vegetação entre 2010 e 2017 ................................................................................ 140

Figura 94. Perda de vegetação entre 2010 e 2017 em Cajamar. 1) Mapa de deteç̧ão de mudanças. 2) Ortofoto 2010/11. 3) Imagem Google Earth 2017 
Figura 95. Alterações de vegetação entre 2010 e 2017 em Guararema. 1) Mapa de detecção de mudanças. 2)

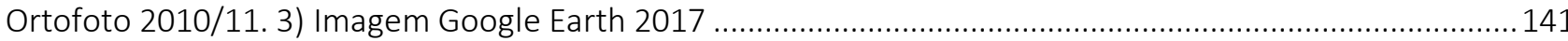

Figura 96. Alterações de vegetação entre 2010 e 2017 em Guarulhos e Arujá. 1) Mapa de detecção de mudanças. 2) Ortofoto 2010/11. 3) Imagem Google Earth 2017 ...............................................................141

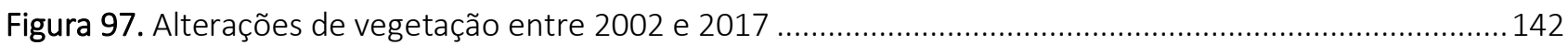

Figura 98. Análise de tendência da $T_{\text {sup }}$ diurna. Sem significância estatística ou prática................................ 143

Figura 99. Análise de tendência da $T_{\text {sup }}$ diurna. Com significância estatística, sem significância prática. ........143

Figura 100. Análise de tendência da $T_{\text {sup }}$ diurna. Com significância estatística e significância prática. ............143

Figura 101. Identificação de tendência. T sup diurna. Identificação de alteração. .............................................. 144

Figura 102. Identificação de tendência. $T_{\text {sup }}$ diurna. Intensidade da alteração............................................. 144

Figura 103. Identificação de tendência. Tsup diurna. Ano de alteração. Redução. .......................................... 145

Figura 104. Identificação de tendência. $T_{\text {sup }}$ diurna. Ano de alteração. Aumento. .......................................... 145

Figura 105. Área com redução significativa de $T_{\text {sup }}$ diurna entre 2003 a 2008/2012 sobre imagem IKONOS de

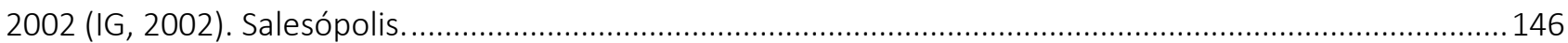

Figura 106. Área com redução significativa de $T_{\text {sup }}$ diurna entre 2003 a 2008/2012 sobre ortofoto 2010

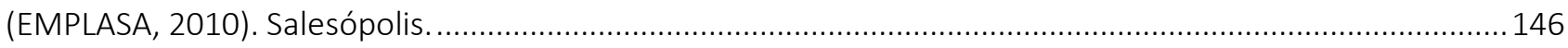

Figura 107. Área com aumento significativo de $T_{\text {sup }}$ diurna na região de Itaquaquecetuba. 1) Mapa de deteç̧ão de mudança. 2) Imagem IKONOS 2002. 3) Imagem Google Earth 2017 147

Figura 108. Área com aumento significativo de $T_{\text {sup }}$ em Ferraz de Vasconcelos. 1) Mapa de detecção de mudança. 2) Imagem IKONOS 2002. 3) Imagem Google Earth 2017

Figura 109. Área com aumento significativo de $T_{\text {sup }}$ diurna na região de Vargem Grande Paulista e Cotia. 1) Mapa de detecção de mudança. 2) Imagem IKONOS 2002. 3) Imagem Google Earth 2017 ...........................148

Figura 110. Área com aumento significativo de $T_{\text {sup }}$ em Cajamar. 1) Mapa de detecção de mudança. 2)

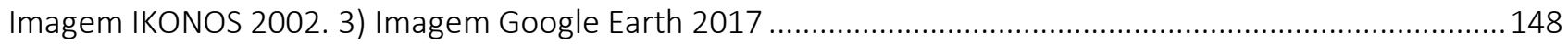

Figura 111. Identificação de tendência. T sup noturna. Identificação de alteração. ......................................... 149

Figura 112. Identificação de tendência. NDVI. Identificação de alteração..................................................... 151

Figura 113. Identificação de tendência. NDVI. Intensidade da alteração.................................................... 151

Figura 114. Identificação de tendência. NDVI. Ano de alteração. Redução. .................................................. 152

Figura 115. Identificação de tendência. NDVI. Ano de alteração. Aumento. ................................................. 152

Figura 116. Identificação de tendência. EVI. Identificação de alteração. ...................................................... 153

Figura 117. Identificação de tendência. EVI. Intensidade da alteração. .........................................................153

Figura 118. Identificação de tendência. EVI. Ano de alteração. Redução. .....................................................154

Figura 119. Identificação de tendência. EVI. Ano de alteração. Aumento. .................................................... 154

Figura 120. Padrões de alteração dos índices de vegetação. ...................................................................... 155

Figura 121. Cruzamento entre tendências: NDVI e T sup diurna. Resolução: 1 km ........................................... 157

Figura 122. Cruzamento entre tendências: NDVI e T sup diurna. Resolução: 250m ...................................... 158

Figura 123. Alterações de vegetação entre 2002 e 2017. Trecho Norte do Rodoanel Mario Covas em

Guarulhos. 1) Mapa de deteç̧ão de mudanças. 2) Imagem IKONOS 2002. 3) Imagem Google Earth 2017 ... 159

Figura 124. $T_{\text {sup }}$ a partir de dados termais do satélite Landsat 7-ETM+ (2002). Resolução espacial 60m. .......159

Figura 125. $T_{\text {sup }}$ a partir de dados termais do satélite Landsat 8-OLI-TIRS (2019). Resolução espacial 100m. 159

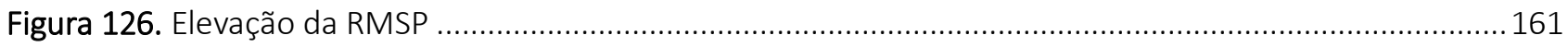

Figura 127. Correlação entre elevação e $T_{\text {sup }}$ diurna das estações chuvosas. Resolução: 250m. .....................161 
Figura 128. Correlação entre elevação e $T_{\text {sup }}$ diurna das estações secas. Resolução: $250 \mathrm{~m}$. 161

Figura 129. Correlação entre elevação e $T_{\text {sup }}$ noturna das estações chuvosas. Resolução: $250 \mathrm{~m}$. 162

Figura 130. Correlação entre elevação e $T_{\text {sup }}$ noturna das estações seca. Resolução: $250 \mathrm{~m}$. 162

Figura 131. Pontos de interesse para estudo de sazonalidade dos índices de vegetação 163

Figura 132. Tipo de ocupação dos pontos de interess 164

Figura 133. Variação do NDVI. Parque da Cantareira, Parque Fontes do Ipiranga, Reserva Morro Grande e Parque do Ibirapuera.

Figura 134. Variação do NDVI. Área que sofreu processo de urbanização em Cajamar, áreas de pasto em Santa Isabel e área de cultivo de eucalipto em Guararema. 165

Figura 135. Variação do EVI. Parque da Cantareira, Parque Fontes do Ipiranga, Reserva Morro Grande e Parque do Ibirapuera.

Figura 136. Variação do EVI. Área que sofreu processo de urbanização em Cajamar, áreas de pasto em Santa Isabel e área de cultivo de eucalipto em Guararema.

Figura 137. A) Área de ponderação do CENSO IBGE 2010 (vermelho). B) UITs EMPLASA 2010 (amarelo). Município de Biritiba Mirim (RMSP) 168

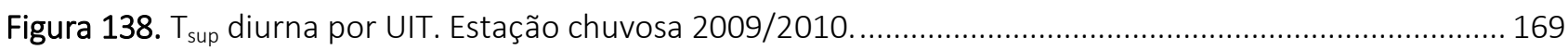

Figura 139. Tsup noturna por UIT. Estação chuvosa 2009/2010................................................................ 169

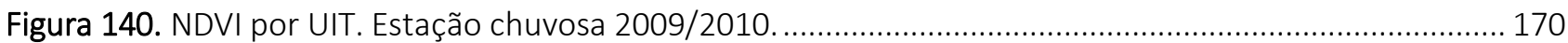

Figura 141. Percentual de pessoas responsáveis pelo domicílio com renda superior a 5 salários mínimos.... 170 Figura 142. A) Mapa de cobertura arbórea. B) Mapa de $T_{\text {sup }}$ diurna. C) Índice de prioridade para plantio. Região Metropolitana de Toronto, Canadá 176

Figura 143. A) Vista aérea e B) Calçada com dimensões insuficientes e vegetação inadequada. Vila Andrade São Paulo. Imagens da autora. 


\section{Lista de tabelas}

Tabela 1. Emissividade, temperatura radiante e verdadeira de diferentes materiais.....................................53

Tabela 2. Síntese dos estudos com aplicação do SR do IVT em pesquisas sobre clima urbano......................... 57

Tabela 3. Síntese dos estudos com aplicação do SR da vegetação com ênfase em pesquisas sobre clima. ...... 68

Tabela 4. Local Climate Zones (LCZ). Tipologias construídas. Adaptado de Stewart e Oke (2012)................... 71

Tabela 5. Local Climate Zones (LCZ). Tipologias de cobertura do solo. Adaptado de Stewart e Oke (2012)...... 72

Tabela 6. Cenas com pixels corrompidos após aplicação da banda de qualidade. ........................................... 78

Tabela 7. Análise do percentual de dados válidos para a RMSP (2003 a 2005) .............................................. 82

Tabela 8. Cenas dos satélites Landsat utilizadas para a elaboração dos mapas LCZ. .................................... 87

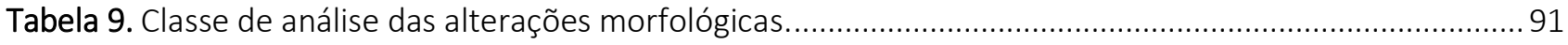

Tabela 10. Diferença entre temperaturas superficiais máximas e mínimas observadas em uma mesma data para a RMSP 119

Tabela 11. Divisões territoriais estudadas.

\section{Lista de equações}

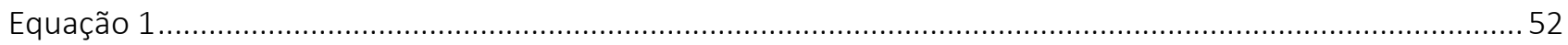

Equação 2

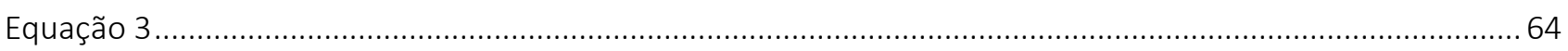




\section{Lista de siglas e abreviaturas}

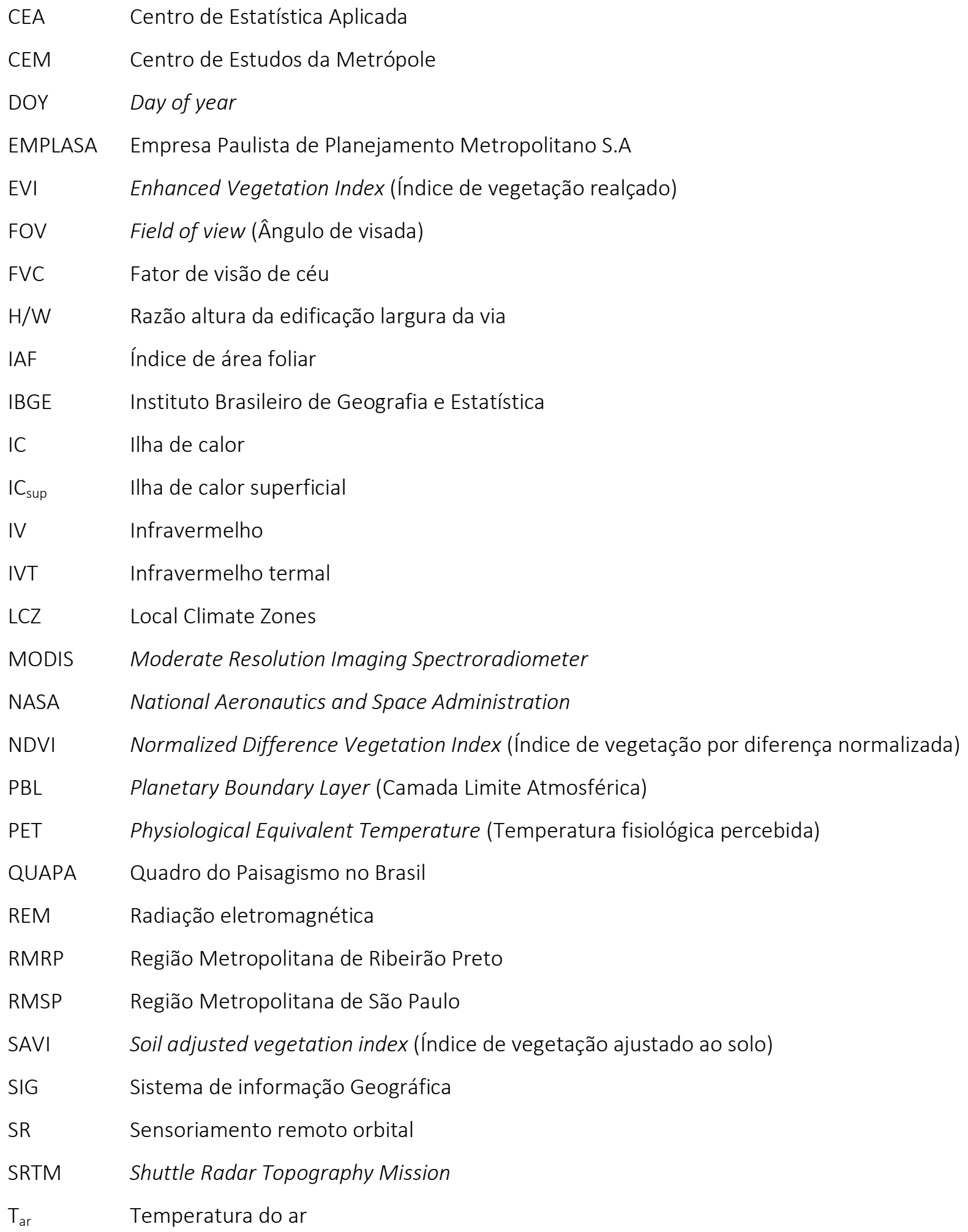


TEP Temperatura equivalente percebida

$\mathrm{T}_{\mathrm{rad}} \quad$ Temperatura radiante

$\operatorname{Tr}_{\text {eal }} \quad$ Temperatura real

$\mathrm{T}_{\text {sup }} \quad$ Temperatura de superfícies

UBL Urban Boundary Layer (Camada Limite Urbana)

UCL Urban Canopy Layer (Camada ao nível das coberturas)

UIT Unidade de informação territorializada

UOS Uso e ocupação do solo

VANT Veículo aéreo não transportado

WUDAPT World Urban Database and Access Portal Tool 


\section{Sumário}

INTRODUÇÃ

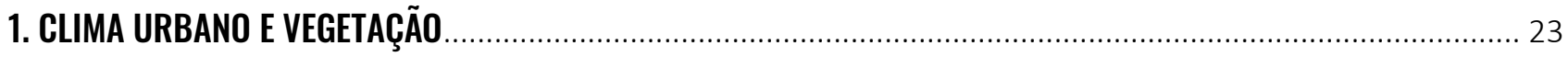

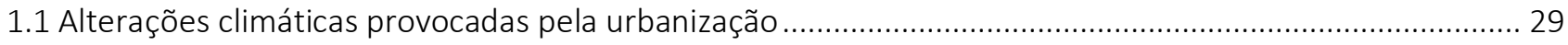

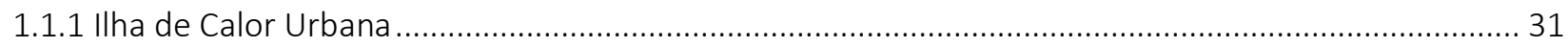

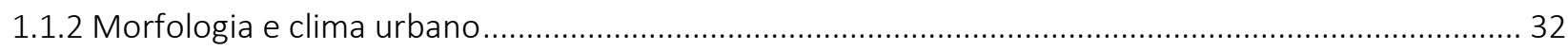

1.1.3 A utilização dos termos 'urbano' e 'rural' em estudos de clima urbano ............................................. 36

1.1.4 Mitigação e adaptação aos efeitos de aquecimento urbano ............................................................. 36

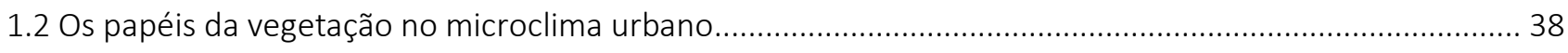

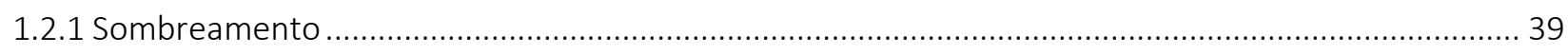

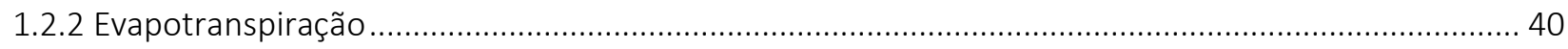

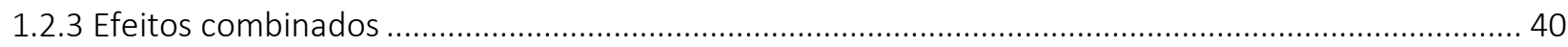

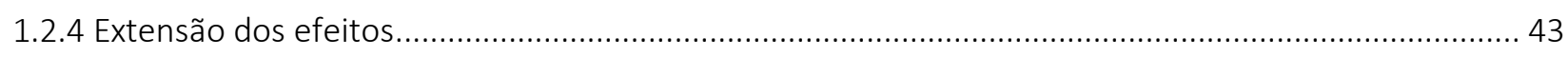

1.2.5 Desafios para sobrevivência da vegetação em área urbana ............................................................. 45

2. TÉCNICAS PARA A OBSERVAÇÃO DA SUPERFíCIE URBANA ................................................................. 47

2.1. Técnicas para observação da temperatura de superfície .................................................................... 47

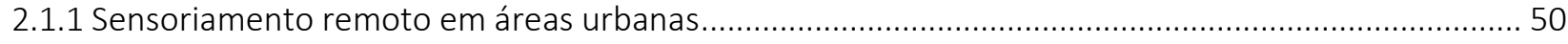

2.1.2 Observação da temperatura de superfície por sensores termais remotos........................................ 51

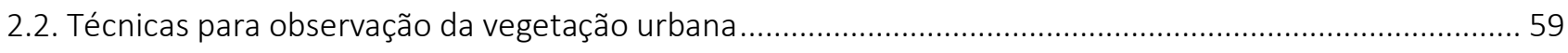

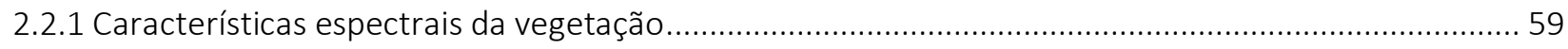

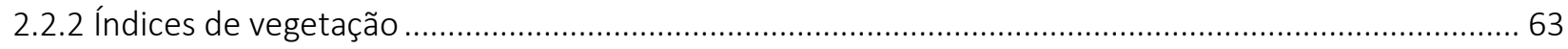

2.2.3 Aplicações do sensoriamento remoto da vegetação com ênfase em análises climáticas ................... 65

2.3. Técnicas para descrição da morfologia urbana .............................................................................. 70

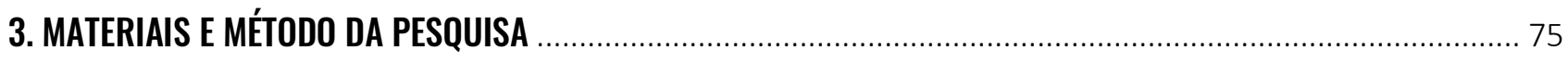

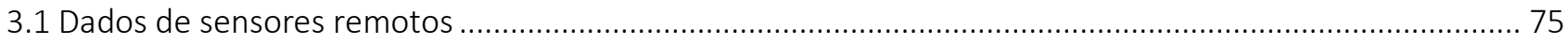

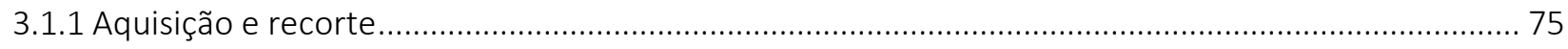

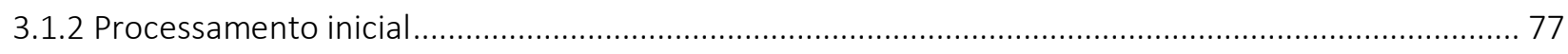

3.1.2.1 Análise da qualidade das imagens e dados ausentes.............................................................. 77

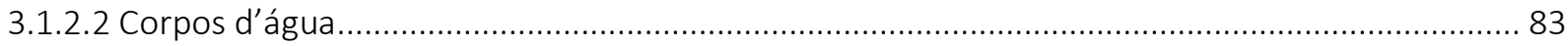


3.1.2.3 Resolução espacial das imagens termais e dos índices de vegetação .......................................... 84

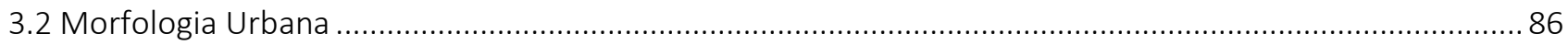

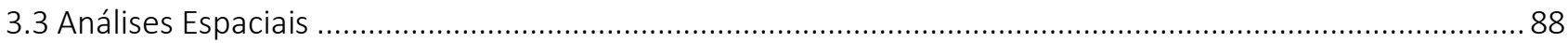

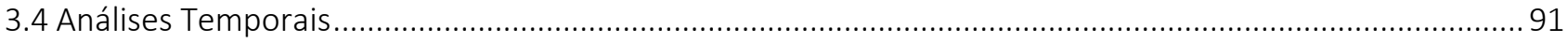

3.4.1 Análise de mudanças na morfologia urbana ................................................................................... 91

3.4.2 Análise de tendência para a temperatura e superfície e índices de vegetação ................................... 92

4. Caracterização espaço-temporal da morfologia, da temperatura de superfície e da vegetação ...................... 95

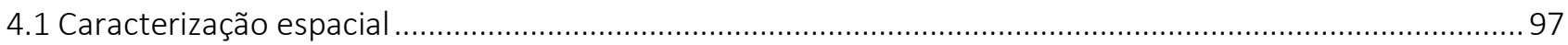

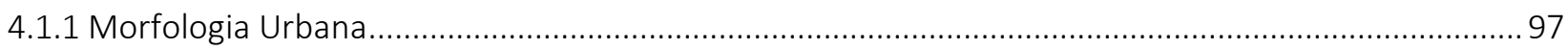

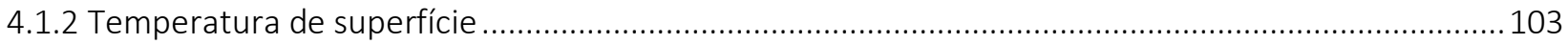

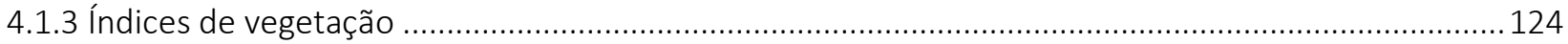

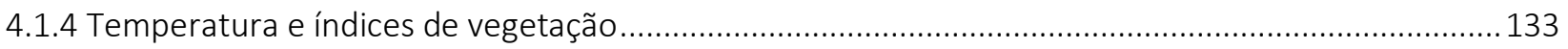

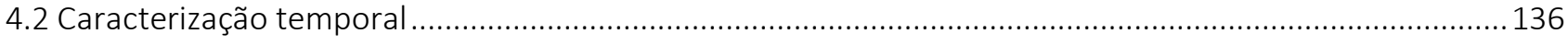

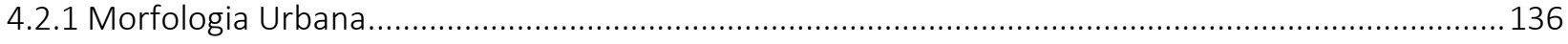

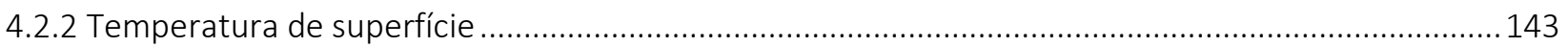

4.2.3 Caracterização temporal dos índices de vegetação .........................................................................150

4.2.4 Tendências de temperatura superficial e índices de vegetação.......................................................157

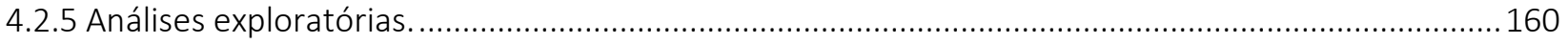

4.2.5.1 Análises exploratórias: temperatura superficial e topografia ...................................................160

4.2.5.2 Análises exploratórias: Índices de vegetação ......................................................................... 162

4.2.5.3 Análises exploratórias: temperatura superficial, vegetação e renda ........................................167

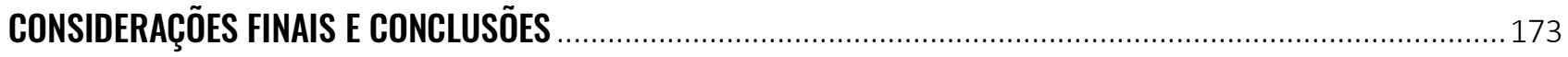

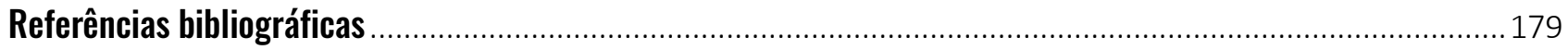

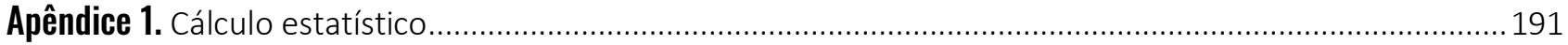

Apêndice 2. Correlações entre índices de vegetação e temperatura de superfície ..........................................195 


\section{INTRODUÇÃO}

Observadas há quase duzentos anos, as alterações provocadas pela urbanização no clima foram sistematizadas apenas recentemente pela climatologia urbana e ainda carecem de incorporação ampla no planejamento das cidades.

Seja por meio de modificações de relevo, das condições da flora e da fauna, do tipo de cobertura do solo ou pelas mudanças das características do regime hídrico, todas as cidades experimentam, em maior ou menor grau, alterações climáticas decorrentes da urbanização.

Característica compartilhada por quase todas as áreas urbanas, a substituição da cobertura vegetal por materiais como pedra e asfalto altera as propriedades físicas das superfícies, diminuindo as taxas de infiltração e de evapotranspiração e alterando seu campo térmico, fatores que aliados à poluição do ar, da água e do solo alteram as condições microclimáticas e hídricas agravando os problemas socioambientais urbanos (OKE et al., 2017; SOUSA; FERREIRA, 2012; VOOGT; OKE, 2003; WENG, 2009; WONG; CHEN, 2009).

O impacto da supressão da vegetação no clima é reportado desde o século XIX. O geógrafo e naturalista prussiano Alexander von Humboldt, em publicações datadas de 1831 e $1843^{1}$, cita três maneiras pelas quais a espécie humana estava afetando o clima: desmatamento, irrigação "inclemente" e a produção pelos centros industriais de "grandes massas de vapor e gás" (WULF, 2016, p.308).

Aumentar a arborização com o objetivo de influenciar o clima local tem sido uma estratégia recomendada por pesquisadores (ALEXANDER et al., 2017; COUTTS, 2015; COUTTS et al., 2016; STONE; VARGO; HABEEB, 2012; WONG; CHEN, 2009) e adotada por algumas cidades, ainda que muitas vezes faltem estudos aprofundados sobre estratégias para a implementação da vegetação, especialmente em cidades com verões quentes (BOWLER et al., 2010).

\footnotetext{
${ }^{1}$ Fragments de géologie et climatologie asiatiques, de 1831 e Asie centrale, recherches sur lês chaînes de montagnes et la climatologie comparée, de 1843 (WULF, 2016).
} 
Em um cenário de mudanças climáticas, onde se prevê que o número de eventos extremos de altas temperaturas e chuvas intensas irá aumentar, estratégias para compatibilizar a existência de vegetação nas áreas densamente construídas tornam-se ainda mais importantes (IPCC, 2014).

A Região Metropolitana de São Paulo (RMSP) insere-se nesse contexto como a quarta maior região metropolitana do mundo (UN/DESA, 2014), que enfrenta graves problemas socioambientais consequentes de um processo de urbanização alheio às limitações naturais impostas pelo território. A população de baixa renda sem alternativa de moradia ocupou áreas ambientalmente frágeis, tanto nas periferias dos municípios como nas áreas mais centrais, muitas delas legalmente protegidas por uma normativa que pretendia restringir a ocupação e assegurar sua preservação, como as Áreas de Preservação Permanente de rios e córregos. Por sua vez, a ocupação formal do território também alterou as características naturais, suprimiu morros, retificou rios e eliminou sistematicamente a cobertura arbórea dando lugar a uma ocupação fragmentada, dispersa e demograficamente pouco densa, ditada pelo capital imobiliário especulativo e muitas vezes amparada pela legislação vigente (FERREIRA, 2012).

O esforço empreendido pelo poder público municipal em criar indicadores e normativas que orientem as ações em relação à vegetação, estabelecendo programas, procedimentos e leis para o corte da vegetação e para a compensação aos danos causados, para o plantio de novas mudas e para a implantação de novas áreas verdes carece de embasamento científico que considere o papel socioambiental da vegetação urbana. A ausência de parâmetros científicos nos procedimentos referentes à definição da compensação ambiental por corte de vegetação na cidade de São Paulo manifestou-se durante minha pesquisa de mestrado.

O trabalho, concluído em 2012, apontou a necessidade prévia de delimitação dos efeitos da perda de cobertura vegetal sobre o meio ambiente e a qualidade de vida da população, para o estabelecimento de compensações ambientais que efetivamente estivessem relacionadas com os papéis da vegetação na cidade de São Paulo, contribuindo assim com a gestão da vegetação urbana (FERREIRA, 2012). 
Sendo assim, o presente trabalho nasce como consequência e evolução da pesquisa do mestrado. O tema inicialmente escolhido para desenvolvimento no doutorado foi o impacto da supressão da vegetação no clima local. Durante o desenvolvimento do trabalho duas escalas de análise delinearam-se: uma temporal, que buscou avaliar as consequências da supressão da vegetação, e outra espacial que buscou avaliar as consequências da presença da vegetação. Assim, não só a perda, mas também a existência da vegetação são consideradas.

O limitado acesso às informações sobre o clima local na RMSP, dada a inexistência de uma rede abrangente de estações de monitoramento microclimático confiável para aferição dos parâmetros necessários para caracterizar o clima local, apontou logo de início, para a utilização do sensoriamento remoto como fonte de informações na escala de trabalho desejada.

A definição do sensoriamento remoto como ferramenta principal para a aquisição dos dados da pesquisa delimitou seus objetos de estudo: a temperatura de superfície, diurna e noturna, a vegetação, indicada pelos índices NDVI e EVI² e a morfologia urbana.

Realizou-se a análise espacial e temporal dos objetos, na escala da RMSP, entre 2002 e 2017. Espacialmente o objetivo consiste em delimitar a relação entre a vegetação, temperatura de superfície e morfologia urbana com a hipótese de que áreas com a presença de vegetação apresentam menor temperatura superficial ao longo de todo o ano. Temporalmente o objetivo é verificar o comportamento da temperatura superficial em áreas com supressão da cobertura vegetal, com a hipótese de que a supressão da vegetação acarreta aumento de temperatura superficial.

O presente trabalho organiza-se em quatro capítulos, além desta introdução e das considerações finais. Os primeiros dois capítulos apresentam a revisão de literatura, sendo o primeiro dedicado às questões do clima urbano e da vegetação e o segundo às técnicas para a observação da superfície urbana. O terceiro capítulo apresenta os materiais e o método adotado na pesquisa, descrevendo o tratamento inicial das imagens

\footnotetext{
${ }^{2}$ NDVI: normalized difference vegetation index, ou índice de vegetação por diferença normalizada. EVI: enhanced vegetation index, ou índice de vegetação melhorado.
} 
de satélite e todo o procedimento para a elaboração das análises espaciais e temporais apresentadas no quarto capítulo.

De caráter interdisciplinar, o presente trabalho utiliza técnicas e processamentos pouco usuais na arquitetura e no urbanismo, como o uso de sensoriamento remoto termal e da vegetação, procedimentos estatísticos e análise de grande quantidade de dados por meio da elaboração de rotinas de programação em linguagem R. Utiliza banco de dados públicos de livre acesso e programas gratuitos, para que a reprodução do que aqui será apresentado não seja por isso um empecilho.

O trabalho aqui apresentado espera contribuir para a melhor compreensão do papel da vegetação no clima urbano e consequentemente para o melhor planejamento da vegetação urbana, tanto daquela que ainda virá a existir, quanto e, sobretudo, daquela existente. 


\section{CLIMA URBANO E VEGETAÇÃO}

Embora as alterações produzidas pelas áreas urbanas no clima sejam observadas há quase 200 anos, foi apenas recentemente que a climatologia urbana, área do conhecimento dedicada ao estudo dos efeitos urbanos na atmosfera, conseguiu organizar o conhecimento acumulado, desenvolvendo metodologias de observação e modelagem climáticas aplicáveis em diferentes regiões do planeta (MILLS, 2014).

Considerado o primeiro a reconhecer a influência das áreas urbanas nos elementos do clima, Luke Howard conduziu estudos comparativos entre o clima da cidade de Londres, Inglaterra, e seus arredores não urbanizados durante 26 anos. Os registros diários de variáveis como temperatura do ar $\left(T_{\text {ar }}\right)$, pressão, precipitação etc. foram publicados inicialmente em 1818 no documento intitulado "The Climate of London" e expandidos em uma segunda edição publicada em 1833 (OKE et al., 2017). Howard identificou que as temperaturas do ar eram mais altas na estação meteorológica localizada no centro de Londres, fenômeno que mais tarde seria denominado como ilha de calor urbana (EMMANUEL, 2005; MILLS, 2014; OKE et al., 2017). Além de descrever o fenômeno observado, Howard especulou as causas deste fenômeno, identificando corretamente a maioria delas: existência de múltiplas reflexões da radiação solar incidente, presença de calor antropogênico, falta de evapotranspiração pela menor presença de vegetação e menor velocidade do vento (DUARTE, 2015; MILLS, 2014).

O maior aquecimento das cidades em relação a seu entorno não urbanizado já havia sido reportado por Noah Webster em 1799 quando registrou a formação de gelo em áreas rurais ao mesmo tempo em que a cidade de Nova lorque registrava $T_{\text {ar }}$ de $4,4^{\circ} \mathrm{C}$, acima do ponto de congelamento. Howard, no entanto, foi o primeiro a documentar cientificamente este fenômeno, sendo considerado o precursor da climatologia urbana (OKE et al., 2017)

No início do século XX o número de estudos sobre clima urbano se expandiu, sendo que vários métodos de observação foram estabelecidos nessa época, sobretudo na Europa Central. Porém, as especificidades destes estudos ao seu local de observação dificultavam a generalização dos procedimentos e uma abordagem sistemática, tarefa alcançada a 
partir dos estudos de Oke nos anos 1970 (MILLS, 2014). É importante ressaltar que os estudos para cidades tropicais permanecem quase inexistentes até os trabalhos de Ernesto Jáuregui para a Cidade do México, publicados em 1973 (OKE et al., 2017).

A partir da década de 1970 a abordagem observacional deu lugar à quantitativa e as pesquisas deixaram de apenas descrever os fenômenos observados e passaram a quantificá-los e relacioná-los com base no princípio do balanço de energia (DUARTE, 2015; MILLS, 2014). Nessa mesma época Oke apresenta uma distinção entre as escalas dos processos climáticos urbanos, mostrada na Figura 1. São detalhadas as diferentes camadas do Planetary Boundary Layer (PBL), ou camada limite atmosférica: O Urban Boundary Layer (UBL), ou camada limite urbana e o Urban Canopy Layer (UCL), ou camada ao nível das coberturas, a camada mais baixa do PBL (ERELL; PEARLMUTTER; WILLIAMSON, 2011; MILLS, 2014).
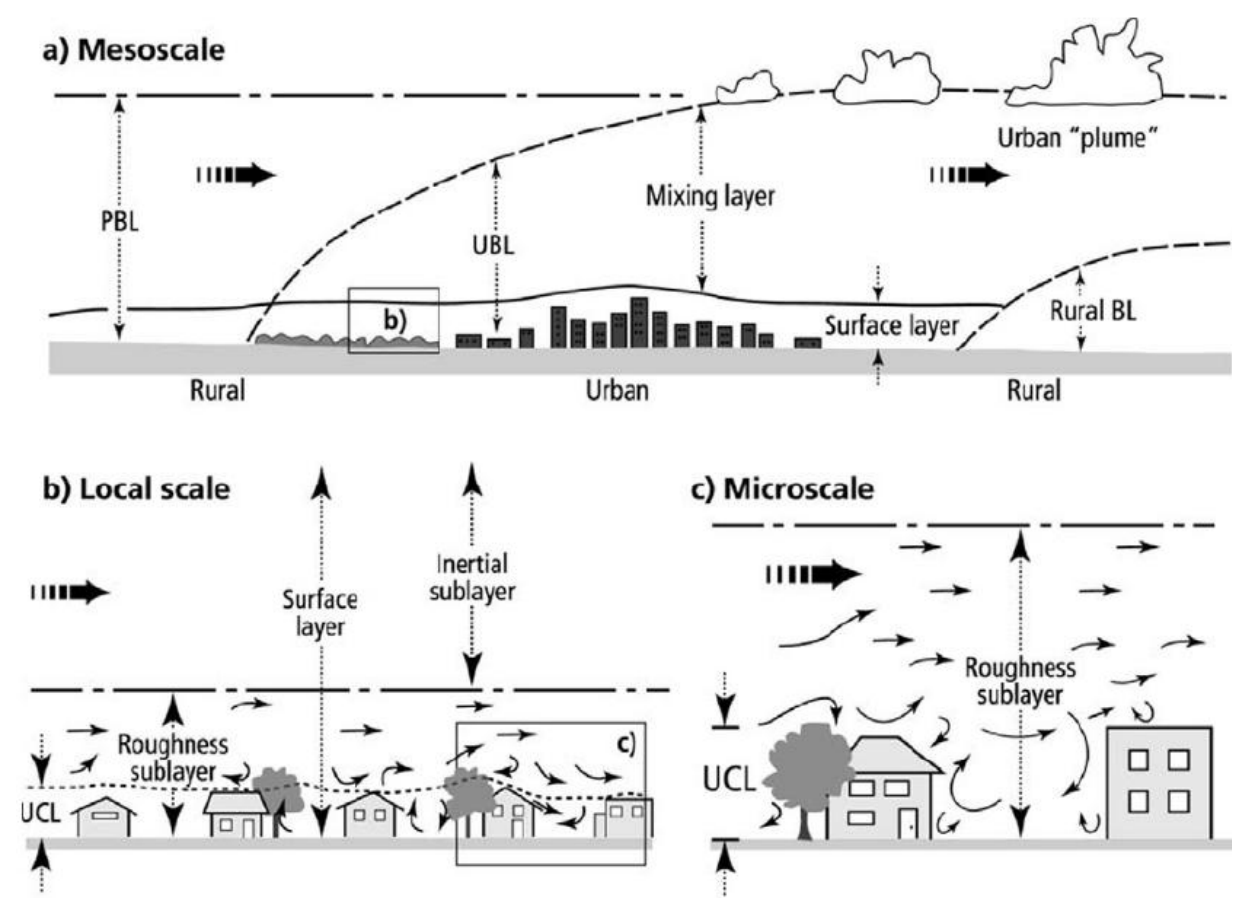

Figura 1. Escalas climáticas e camadas verticais em áreas urbanas. PBL, UBL e UCL.

Fonte: OKE, 2004

Inicialmente, as generalizações promovidas por Oke nos anos 1970 baseavam-se na relação entre a ilha de calor urbana e o tamanho da cidade, descrito por sua população. A aquisição de informação sobre a forma e a função das cidades baseada em seu número de habitantes mostrou-se insuficiente e no início dos anos 1980 Oke passa a utilizar a 
geometria determinada pela via e seus edifícios adjacentes para explicar a combinação dos fenômenos termais e radiativos responsáveis pela magnitude da ilha de calor urbana. Tal geometria passa a ser denominada "cânion urbano", sendo aferida pela relação entre a altura dos edifícios em relação à largura da via (H/W) ou pelo fator de visão de céu (FVC) (Mills 2014; OKE et al., 2017).

É apenas nos anos 1980, porém, que as relações entre formas urbanas reais e efeitos climáticos são evidenciadas. Os avanços computacionais permitiram uma modelagem numérica do ambiente urbano mais detalhada e sofisticada, possibilitando a incorporação de parâmetros mais realistas dos materiais e da morfologia urbana, bem como do calor antropogênico produzido nas cidades (Mills 2014).

A pesquisa sobre clima urbano em áreas tropicais, praticamente inexistente até os anos 1970, progrediu intensamente a partir dos anos 1980. Em levantamento feito por Jáuregui (1999) constatou-se que a produção sobre clima tropicais dobrou entre os anos 1980 e 1990, no entanto, representava apenas $20 \%$ da produção sobre as latitudes médias. Assis (2005) acrescenta que, apesar de seu relevante crescimento até os anos 2000, a pesquisa produzida sobre climas tropicais ainda centrava-se na descrição dos fenômenos de aquecimento e de poluição atmosférica, a despeito da modelagem e do desenvolvimento de aplicações para o planejamento urbano com base no balanço energético.

A necessidade de maior integração entre a climatologia urbana e o planejamento urbano, apontada desde o início dos anos 2000 (ASSIS, 2005; JÁUREGUI, 1999; MILLS, 1999) continua sendo evidenciada em trabalhos mais recentes (DUARTE, 2015; ERELL, 2008; KATZSCHNER, 2010; MILLS, 2014). Estes, porém, salientam a necessidade da transferência de conhecimento de forma acessível, aplicável e com foco na qualidade de vida dos habitantes das cidades.

A importância das questões ambientais e climáticas no desenho dos assentamentos humanos é reconhecida no Oriente há mais de 3.500 anos com a aplicação dos conceitos do "Feng-Shui" no desenho das cidades e dos edifícios na China (ZHAO et al., 2011). No Ocidente, tais questões estão presentes desde os tempos Romanos, conforme indicado no livro I de Vitrúvio, publicado no século I A.C (ERELL, 2008; EMMANUEL, 2005). Vitrúvio 
tece diversas considerações acerca da localização ideal das cidades do ponto de vista da salubridade em relação às características do clima local:

“[...] primeiramente, a escolha de um lugar salubérrimo, que fosse elevado, livre de neblina e de geadas, voltado para regiões do céu não muito quentes nem muito frias, mas temperadas, evitando-se depois a vizinhança dos pântanos. Pois as brisas da manhã, chegando à cidade com o sol nascente, e as brumas delas originadas, acrescidas das exalações venenosas dos animais dos pântanos, espalham-se com um sopro pelos corpos dos habitantes tornando o lugar infecto [...]" (POLIÃO, 1999, p.57).

Mais recentemente o tema aparece em diversos trabalhos que tratam de arquitetura bioclimática, cujos precursores foram Olgyay, com Design with Climate. Bioclimatic Approach to Architectural Regionalism, e Givoni, Man, Climate and Architecture, ambos publicados na década de 1960 (ERELL, 2008; DUARTE, 2015).

A incorporação dos conhecimentos de clima urbano no planejamento das cidades de forma consistente é bastante recente e ainda restrita. As dificuldades de comunicação entre a climatologia e o planejamento urbano, que por muito tempo dificultaram a incorporação do conhecimento climáticos nos mecanismos de tomada de decisão, foram exploradas por diversos pesquisadores. Apesar de parcialmente superadas em algumas partes do mundo, tais dificuldades ainda estão presentes na realidade brasileira.

Mills (2014) atribuiu a falta de integração entre estas áreas a diversos fatores: à falta de treinamento de arquitetos e urbanistas em ciências atmosféricas, que os impede de julgar a aplicabilidade da pesquisa sobre o clima urbano; à diferença de objetivos das pesquisas: enquanto climatologistas urbanos centram-se nas alterações que as áreas urbanas provocam nas propriedades atmosféricas, arquitetos e urbanistas buscam diretrizes de 
projetos que atendam determinadas situações $^{3}$ e à dificuldade dos climatologistas em comunicar seus resultados de forma mais acessível aos arquitetos e urbanistas.

Apesar das divergências, o autor aponta alguns temas de interesse comum às duas áreas, entre eles a pesquisa empírica sobre os efeitos urbanos em áreas tropicais, onde há tanto um imperativo de planejamento quanto uma carência de conhecimento. Esse tipo de pesquisa possibilitaria que os modelos baseados em processos desenvolvidos pela climatologia urbana para latitudes médias pudessem ser aplicados em áreas tropicais. Outro tema de interesse seria a relação entre formas urbanas reais e clima. A climatologia normalmente trabalha com morfologias genéricas, enquanto a literatura em arquitetura e urbanismo refere-se, sobretudo, às formas urbanas tradicionais, ou primitivas, para ilustrar a integração entre ocupação urbana e clima. Examinar formas urbanas reais conectaria as duas áreas e poderia fornecer informação sobre a relação entre projeto e clima.

Para Assis (2005) a dificuldade de aplicação da climatologia urbana no planejamento deve-se à falta de modelos que embasem estudos exploratórios para a tomada de decisão. Apesar de avanços na abordagem preditiva da influência da geometria urbana na temperatura e umidade do ar, na ventilação e no conforto humano em áreas externas, muitos desses modelos são empíricos, ou muito simples, o que restringe sua ampla aplicação. Outro fator limitante é que a maior parte dos trabalhos é descritiva, sendo seus resultados restritos à área em estudo.

Erell (2008) aponta duas razões para que, apesar de reconhecidas, as questões climáticas não tenham sido incorporadas no planejamento das cidades. A primeira é o automóvel, que segundo o autor substituiu o ser humano como foco de atenção do projeto dos espaços abertos e a segunda é o avanço tecnológico dos sistemas de aquecimento e resfriamento artificial, que permitiram aos arquitetos evitar algumas das consequências negativas de se projetar edifícios sem considerar as questões ambientais.

Mills (2014) acrescenta que parte do problema deve-se à importância dada às questões climáticas frente a outras questões do planejamento urbano. No entanto, essa afirmação

\footnotetext{
${ }^{3}$ Mills (2014) destaca a falta de parâmetros de conforto para áreas externas em comparação com áreas internas.
} 
não é universal, uma vez que a cidade de Stuttgart, por exemplo, possui um departamento de climatologia urbana desde o final dos anos 1930 (HEBBERT, 2014; MILLS, 2014)

Hebbert e Jankovic (2011) consideram que estamos em uma nova fase da relação entre a climatologia urbana e suas aplicações na vida urbana cotidiana, marcada, em parte, pelas alterações climáticas globais ${ }^{4}$ e pelo crescente papel das cidades na mitigação das causas e adaptação a esse fenômeno. Além disso, essa nova fase se deve ainda à combinação de diversas inovações técnicas, que reduziram o custo da observação meteorológica, e grandes avanços no poder computacional para modelagem da dinâmica de fluidos, incluindo dados numéricos sofisticados porém acessíveis, além de programas de modelagem como o ENVI-met ${ }^{5}$. Todos esses fatores, segundo os autores, deixam pouca margem para que os problemas do aquecimento provocados pelo ambiente urbano não sejam considerados.

Wang, Zhan e Guo, (2016) destacam a questão da escala como uma barreira entre os dois campos. Segundo os autores as pesquisas sobre os padrões termais urbanos focaram, por muitos anos, na escala da cidade, com comparações entre cidade e campo. As conclusões obtidas com esse tipo de análise não captam a diversidade local, sendo de difícil utilização para o planejamento urbano, cuja escala de atuação e tomada de decisão em relação às medidas de mitigação dos fenômenos de aquecimento é local.

A ligação entre planejamento, arquitetura e clima com aplicações práticas no desenho das cidades, pode ser reconhecida, porém, apenas em algumas cidades do mundo, com destaque para as cidades alemãs de Stuttgart, Berlim e Freiburg (DUARTE, 2015; MILLS, 2014) e mais recentemente em Barcelona, Nova lorque, Toronto, Sydney, Melbourne, Singapura, Londres, Paris, Copenhagen e em Hong Kong e Lisboa com a aplicação de mapas climáticos urbanos ${ }^{6}$ nas normativas de desenho das cidades (NG, REN e KATZSCHEBER, 2011).

\footnotetext{
${ }^{4}$ Mudanças que provocaram ondas de calor na Holanda em 2003 e 2006, com diversos óbitos associados, impulsionaram a retomada da pesquisa sobre fenômenos de aquecimento no país (HEBBERT; JANKOVIC, 2011).

${ }^{5}$ O programa encontra-se atualmente em sua quarta versão e está disponível em: https://www.envi-met.com/.

${ }^{6}$ O mapa climático urbano é uma ferramenta para análise e avaliação climática em planejamento urbano que apresenta os fenômenos e problemas climáticos em formato bidimensional (KATZSCHNER, 2010; REN, 2015).
} 
A falta de integração entre clima e desenho urbano é especialmente preocupante nas mega cidades localizadas nas regiões menos desenvolvidas do planeta, que nas últimas décadas apresentaram elevados índices de crescimento populacional, associados a sérias degradações ambientais (ROTH, 2007). Outro fator preocupante é que, apesar de muitas destas cidades estarem localizadas em áreas tropicais (latitudes entre $23,5^{\circ}$ Sul e $23,5^{\circ}$ Norte) e subtropicais (latitudes entre $23,5^{\circ}$ e $35^{\circ}$ Sul e Norte), a maior parte dos estudos existentes sobre clima urbano trata das áreas temperadas do planeta, sendo estes alguns dos fatos que apontam a urgência de estudos que associem clima e planejamento urbano em regiões tropicais (EMMANUEL, 2011; MILLS, 2014; ROTH, 2007).

\subsection{Alterações climáticas provocadas pela urbanização}

Efeitos urbanos no ambiente estão presentes em maior ou menor grau em todas as cidades (OKE et al., 2017). De maneira geral, as cidades modificam as configurações de relevo, as condições da flora e da fauna, as características do regime hídrico e climático, alterando os fluxos de energia e o ciclo de nutrientes, produzindo um ecossistema muito diferente daquele que existia antes de seu estabelecimento (SPIRN, 1995; ALBERTI, 2009; WENG, 2009). Uma das consequências verificadas na maioria dos processos de urbanização é a substituição da cobertura vegetal por materiais como pedra e asfalto. Esta substituição altera as propriedades físicas das superfícies, diminuindo as taxas de evapotranspiração e alterando seu campo térmico, fatores que aliados à poluição do ar, da água e do solo alteram as condições microclimáticas, hídricas, de permeabilidade etc., agravando os problemas socioambientais como enchentes e deslizamentos e impactando a qualidade de vida nos centros urbanos (OKE et al., 2017; SOUSA; FERREIRA, 2012; VOOGT; OKE, 2003; WENG, 2009; WONG; CHEN, 2009).

As razões que distinguem o clima da cidade do verificado nas áreas não urbanizadas estão relacionadas às propriedades radiativas, térmicas, aerodinâmicas e de umidade dos materiais constituintes das áreas urbanas. As propriedades radiativas incluem as características geométricas, de absorção, refletividade, transmissividade e emissividade dos materiais constituintes do tecido urbano. As propriedades termais incluem o calor 
específico, a capacidade térmica, a condutibilidade térmica e a admitância ${ }^{7}$ desses materiais. As características aerodinâmicas dizem respeito à rugosidade e porosidade do tecido urbano e as propriedades de umidade englobam a capacidade de interceptação e armazenamento de água, permeabilidade dos materiais e características estomatais da vegetação (OKE et al., 2017).

Dessa forma, as diferentes morfologias urbanas, por apresentarem geometrias e revestimentos distintos, influenciam de maneira particular o clima. A escala de análise dos fenômenos climáticos urbanos é importante para a delimitação dessas influências, sendo que a homogeneidade em uma escala pode representar heterogeneidade em outras (OKE et al., 2017). O clima urbano se diferencia do clima em áreas não urbanas, mas o clima não é homogêneo em toda a área urbana. Um bairro bem arborizado não apresenta as mesmas características climáticas de outro densamente construído e sem vegetação. Em um mesmo bairro poderão ser encontradas distinções entre áreas abaixo do dossel vegetal e áreas expostas à radiação solar direta, mesmo que tais áreas sejam adjacentes.

Áreas urbanas compostas por materiais artificiais, duros e impermeáveis, proporcionam maior armazenamento de calor e diminuição das taxas de evaporação. A presença de edificações aumenta a rugosidade e provoca a diminuição da velocidade dos ventos. Esses fatores alteram o balanço entre a energia solar, usada para aumentar a $T_{\text {ar }}$ (processo de aquecimento), e a energia usada no processo de evaporação (processo de resfriamento) (KATZSCHNER, 2010; OKE et al., 2017) fazendo com que os padrões de temperatura e de velocidade do vento no nível do pedestre sejam diferentes dos verificados nas áreas não urbanizadas (GIVONI, 1998).

Em média, as temperaturas do ar nas áreas construídas mais densas são maiores do que no entorno menos urbanizado da cidade, sendo que esta diferença é mais acentuada em noites claras e sem vento. A essa diferença noturna da temperatura nas áreas mais densamente edificadas dá-se o nome de ilha de calor, termo cunhado pela primeira vez nos anos 1940 (STEWART; OKE, 2012), mas observada há mais de 200 anos por Luke Howard em medições realizadas na cidade de Londres (OKE et al., 2017)

\footnotetext{
${ }^{7}$ Admitânica térmica ou inércia térmica é uma propriedade dos materiais que descreve sua capacidade de acumular ou perder calor. É medida em $\mathrm{W} / \mathrm{m}^{20} \mathrm{C}$. (OKE et al, 2017).
} 


\subsubsection{Ilha de Calor Urbana}

As ilhas de calor ocorrem em quase todas as áreas urbanas, independente de seu tamanho ou clima (ROTH, 2007). Estudos recentes constataram que sua intensidade pode ser inferior nas cidades localizadas em áreas tropicais e subtropicais, onde o fenômeno pode ser mais intenso durante o dia (ROTH, 2007), ainda que este entendimento não seja consensual até o momento. Tradicionalmente é descrita como a diferença entre a $T_{a r}$ medida a uma altura do solo entre 1 e 2 metros, em duas ou mais estações meteorológicas localizadas em áreas classificadas como urbanas e rurais, no período noturno (STEWARD; OKE, 2012).

A ilha de calor observada na atmosfera pode ser subdividida em ilha de calor da camada limite urbana e ilha de calor da camada ao nível das coberturas. Também é possível observar a ilha de calor na superfície, nesse caso ela é denominada ilha de calor superficial (ERELL; PEARLMUTTER; WILLIAMSON, 2011).

A ilha de calor da camada ao nível das coberturas, ou apenas ilha de calor urbana, é observada na camada de ar próxima às superfícies urbanas (Figura 1-C). É tipicamente observada à noite, sob condições de pouca nebulosidade e ausência de vento. A ilha de calor da camada limite urbana (Figura 1-A) configura-se como uma camada de ar quente acima da cidade que pode estender-se horizontalmente por um ou mais quilômetros (ERELL; PEARLMUTTER; WILLIAMSON, 2011; OKE et al., 2017).

A ilha de calor de superfície acontece quando as temperaturas das superfícies urbanas são maiores do que as de seu entorno. Isso ocorre quando o entorno é coberto por vegetação ou solo úmido, que apresentam temperaturas superficiais inferiores às dos materiais urbanos, o que não pode ser verificado, porém, em cidades com entorno desértico ou com terreno rochoso. Apresenta maior intensidade durante o dia, especialmente naqueles ensolarados e com pouco vento (ERELL; PEARLMUTTER; WILLIAMSON, 2011). A Figura 2 apresenta uma descrição esquemática da variação de temperaturas do ar e de superfície, diurnas e noturnas em uma cidade plana. 

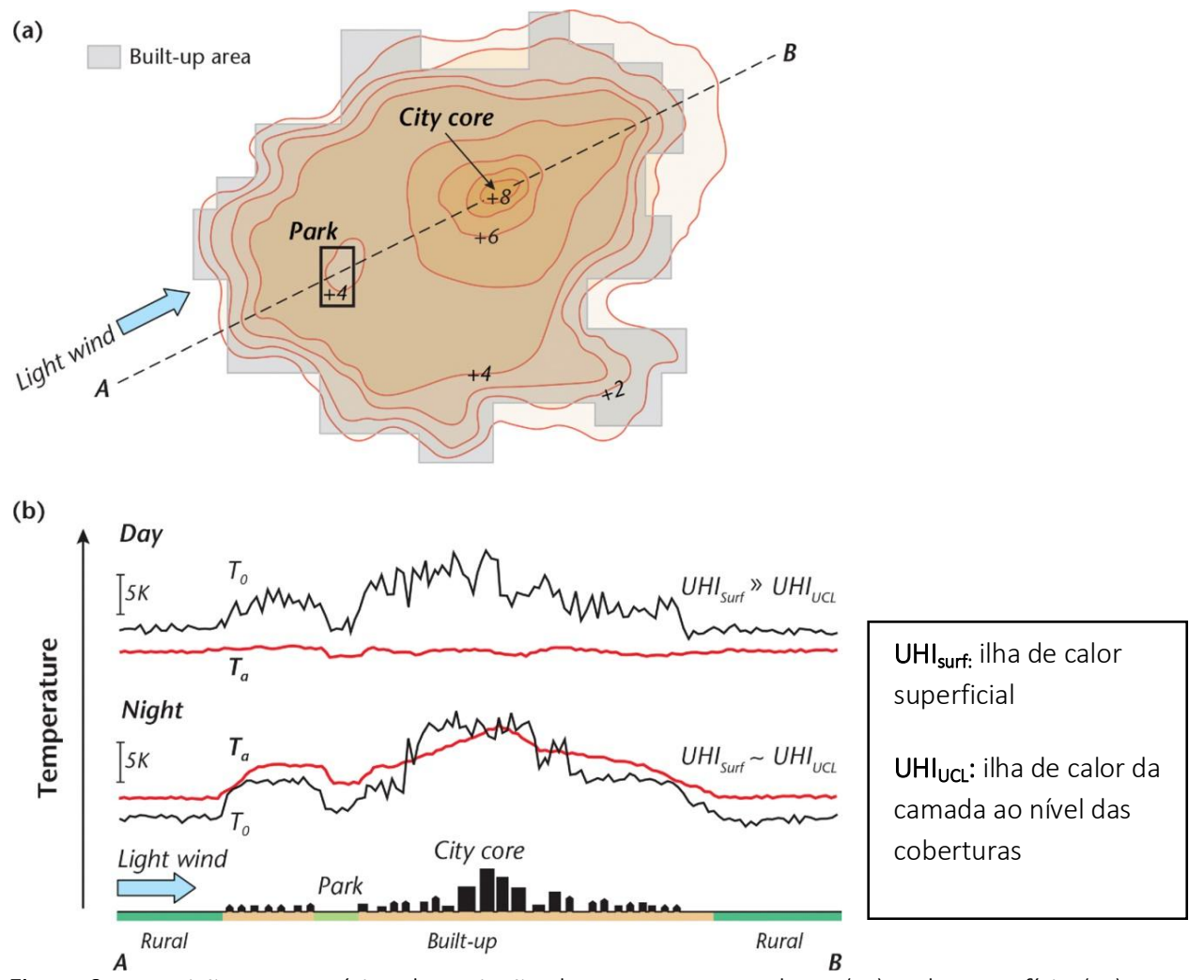

Figura 2. Descrição esquemática da variação das temperaturas do $\operatorname{ar}\left(T_{a}\right)$ e da superfície $\left(T_{0}\right)$ em uma cidade plana. (a) mapa de isotermas mostrando padrões típicos da ilha de calor urbana. (b) variação diurna e noturna das temperaturas do $\operatorname{ar}\left(T_{a}\right)$ e da superfície $\left(T_{0}\right)$ ao longo da seção A-B. Fonte: OKE et al, 2017.

\subsubsection{Morfologia e clima urbano}

As causas para os fenômenos de aquecimento urbano são complexas e possuem relação com a estrutura das áreas urbanas e com o tipo de cobertura do solo (STEWART, OKE, 2012; DUARTE, 2015). Dentre as causas apontadas por diferentes autores (EMMANUEL, 2005, 2011; IMHOFF et al., 2010; OKE et al., 2017; TAHA, 1997) destacam-se:

- Características da estrutura ${ }^{8}$ das áreas urbanas. A geometria urbana é caracterizada pela repetição de cânions urbanos que restringem a visão do céu, caracterizado pelo FVC, provocando múltiplas reflexões da radiação solar. Estas múltiplas reflexões da radiação aumentam a absorção de calor pelas superfícies do cânion, quando comparadas com uma superfície plana. Além disso, a

\footnotetext{
${ }^{8}$ A estrutura das áreas urbanas pode ser entendida como a configuração tridimensional dos elementos urbanos: a dimensão dos edifícios e o espaço livre entre eles (OKE et al., 2017).
} 
movimentação de ar normalmente é restrita, o que reduz as trocas convectivas turbulentas e diminui a capacidade de perda de calor pela ventilação. A pouca visão de céu restringe ainda a perda de radiação de onda longa, dificultando o arrefecimento das superfícies;

- Propriedades das superfícies. Os baixos albedos e altas admitâncias proporcionam maior armazenamento de calor. As superfícies urbanas se aquecem durante o dia e, pelo princípio do equilíbrio térmico, liberam o calor acumulado durante a noite, contribuindo para o aquecimento do ar;

- Ausência de vegetação. A substituição das áreas naturais com vegetação por edificações e áreas pavimentadas faz com que a maior parte da radiação solar incidente seja convertida em calor sensível, ao invés de calor latente. Isso se deve às propriedades dos materiais urbanos. Ademais, a falta de sombreamento proporcionado pelas árvores urbanas contribui com o maior aquecimento das superfícies. O papel da vegetação no clima urbano será discutido em detalhes no item 1.2.

- Calor antropogênico, água e poluentes. Grandes quantidades de calor sensível são liberadas pelos processos industriais, pelo resfriamento e aquecimento de espaços internos e na queima de combustíveis fósseis usados no transporte urbano. As áreas urbanas também eliminam na atmosfera água em estado líquido e gasoso, oriunda de processos industriais, de processos de condicionamento do ar interno e irrigação de áreas verdes. Também são eliminadas grandes quantidades de poluentes particulados e gasosos. Tais emissões, de calor, água e poluentes, variam conforme a hora do dia e da semana.

A maior parte das variáveis descritas acima está diretamente relacionada com o desenho da cidade, com sua forma de ocupação e com a escolha dos materiais. Stone, Vargo e Habeeb (2012) reportam que as alterações no uso do solo e a substituição da cobertura natural por materiais de construção desempenham papel mais significativo na intensidade da ilha de calor urbana do que os gases de efeito estufa. 
Uma avaliação empírica dos efeitos da morfologia urbana no clima local de Beijing, China, durante o período de verão, feita por Zhao et al. (2011), constatou que três indicadores usados em planejamento urbano podem explicar de 99,49\% a 99,69\% das diferenças microclimáticas locais nas temperaturas de superfície, nos picos de temperatura e no horário de ocorrência dos picos de temperatura. Os três indicadores levantados foram: densidade construída, altura das edificações e cobertura vegetal, sendo a última o indicador mais significativo. De acordo com Emmanuel (2011) é provável que a manipulação desses três indicadores possa reduzir significativamente o aquecimento em cidades quentes e úmidas.

Isolar as causas dos fenômenos de aquecimento urbano é complexo, uma vez que alterações em uma característica do sistema urbano frequentemente provocam modificações em mais de um processo (OKE et al., 2017).

Scarano e Sobrino (2015) avaliaram a relação entre a geometria urbana descrita pelo FVC e a temperatura de superfície ( $\left.T_{\text {sup }}\right)$ diurna e noturna da cidade de Bari, Itália. Os autores utilizaram imagens de sensoriamento remoto para obtenção da $T_{\text {sup }}$ e um modelo 3D da cidade para calcular o FVC. Os resultados para diferentes datas ao longo dos anos de 2013 e 2014 mostraram que existe correlação positiva entre as duas variáveis, ou seja, a $T_{\text {sup }}$ aumenta proporcionalmente ao FVC, conforme Figura 3 e Figura 4.

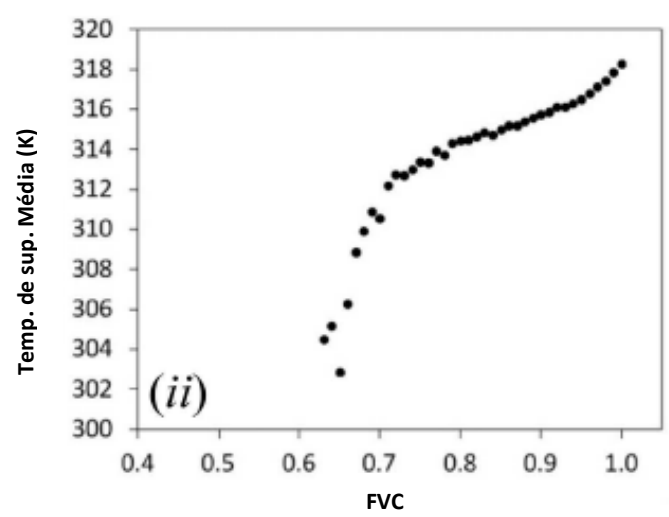

Figura 3. Relação entre a média da $T_{\text {sup }}$ e FVC para o dia 07/Agosto/2013. Fonte: Scarano e Sobrino (2015).

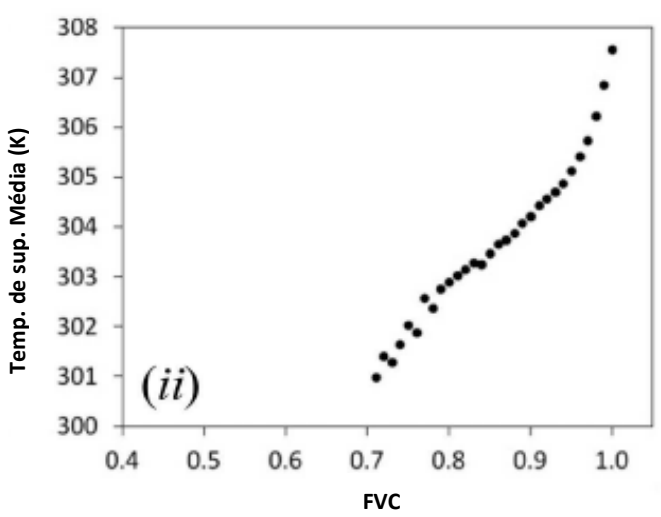

Figura 4. Relação entre a média da $T_{\text {sup }}$ e FVC para o dia 24/Setembro/2013. Fonte: Scarano e Sobrino (2015).

Segundo este estudo, durante o dia a $\mathrm{T}_{\text {sup }}$ está fortemente relacionada à exposição solar das superfícies. Aquelas localizadas nas áreas mais verticalizadas da cidade, e que 
possuem baixo FVC, se aquecem mais lentamente durante o dia por conta do sombreamento dos edifícios. As superfícies com alto FVC, portanto mais expostas, se aquecem rapidamente durante o dia. Durante a noite as superfícies localizadas em ruas estreitas com edifícios altos apresentam resfriamento lento, uma vez que as trocas de radiação de onda longa com a atmosfera são restritas. Já as superfícies com maior FVC perdem o calor acumulado durante o dia com mais facilidade e velocidade, pois estão mais expostas às trocas radiativas (SCARANO; SOBRINO, 2015).

Em estudo realizado para a cidade de Colombo, Sri Lanka, Johansson e Emmanuel (2006) avaliaram o conforto de cinco áreas diferentes da cidade por meio do cálculo da temperatura fisiológica equivalente (PET) a partir de dados microclimáticos medidos na estação quente. Os autores verificaram os menores níveis de conforto em ruas largas com edifícios baixos, ou seja, com FVC alto e H/W baixo. As situações mais confortáveis foram encontradas em ruas estreitas, com edifícios altos, especialmente nas que possuíam vegetação arbórea. Em regiões de baixas latitudes o sombreamento proporcionado por edifícios altos nos horários próximos ao meio-dia solar é limitado. Assim, é necessário que o desenho urbano utilize outras estratégias de sombreamento do espaço livre, sendo o uso da vegetação arbórea uma das estratégias recomendada pelos autores.

Cânions com alto H/W podem interferir negativamente na ventilação caso o arranjo dos edifícios e o desenho do embasamento não tenham sido pensados para tal. Este tipo de configuração urbana também terá efeito negativo à noite, uma vez que o baixo FVC dificulta a perda de calor para a atmosfera (JOHANSSON; EMMANUEL, 2006), conforme será discutido no item 1.2.

Resultados semelhantes à Colombo foram encontrados por Krüger, Minella e Rasia (2011) para a cidade de Curitiba. Nesse caso, altos valores de FVC proporcionaram maior desconforto em dias quentes, porém maior conforto em dias frios.

Sendo as alterações de uso do solo controladas pelo planejamento e projeto urbano pode-se considerar possível modificar o clima urbano por meio de políticas públicas que promovam um desenho urbano climaticamente responsável, que contribua para o conforto dos habitantes nos espaços abertos e no interior dos edifícios, reduza a 
demanda de energia das edificações para aquecimento e/ou resfriamento (GIVONI, 1998) e diminua as diferenças de $T_{\text {ar }}$ entre as áreas urbanas e rurais.

\subsubsection{A utilização dos termos 'urbano' e 'rural' em estudos de clima urbano}

Stewart e Oke (2012) questionam a adoção dos termos 'urbano' e 'rural' para caracterizar ocupação do solo e descrever a ilha de calor. Apesar de serem conceitos bastante simples e conhecidos, essa classificação dicotômica não apresenta significado objetivo do ponto de vista climático. Ao analisarem diferentes estudos sobre ilhas de calor, os autores verificaram uma grande variedade de paisagens urbanas e rurais em diferentes cidades do mundo, dificultando a comparação dos dados entre elas. Para sanar tais deficiências propuseram uma nova classificação das áreas urbanas e rurais baseadas em suas características climáticas. O método visa ser universalmente aplicável para, de forma relativamente simples, permitir uma melhor comparação entre os estudos de diferentes cidades.

A classificação proposta por Stewart e Oke (2012)denominada Local Climate Zones (LCZ), parametriza regiões com a mesma cobertura do solo, estrutura, materiais e atividades humanas. Estas regiões mais ou menos uniformes podem estender-se por centenas de metros ou quilômetros. A proposta objetiva extrair a magnitude da ilha de calor não mais pela diferença de $T_{a r}$ entre a área urbana e a rural, mas por meio da diferença entre as LCZs, dessa forma evitam-se confusões sobre o que é urbano e rural e obtém-se uma classificação que proporciona a análise dos fenômenos de aquecimento, pois apresenta características físicas das superfícies que incluem aspectos morfológicos e materiais. Esta metodologia será detalhada no Capítulo 2, item 2.3.

\subsubsection{Mitigação e adaptação aos efeitos de aquecimento urbano}

Mitigar os efeitos da ilha de calor urbana, principalmente onde eles são indesejados, como nas cidades de clima quente ou com verões quentes, deve ser uma das prioridades dos planejadores urbanos, arquitetos e empreendedores, pois as altas temperaturas, além de aumentarem a demanda de energia para resfriamento das edificações (TAHA; AKBARI; ROSENFELD, 1991; YENNETI et al., 2017) estão diretamente relacionadas à saúde da população e aos índices de mortalidade (KATZSCHNER, 2010). 
A correlação entre altas temperaturas e aumento da mortalidade das populações urbanas, especialmente em eventos extremos de onda de calor, tem sido relatada por pesquisadores de diferentes cidades do mundo (ADAMS; SMITH, 2014; BOWLER et al., 2010; DOUSSET et al., 2011; ROTH, 2007; SALATA et al., 2017; SANTAMOURIS; KOLOKOTSA, 2016). Ainda que mais aclimatadas às altas temperaturas, as populações urbanas de cidades tropicais e subtropicais também estão vulneráveis. Centenas de pessoas morreram na Índia e no Paquistão durante uma forte onda de calor em 1995 e 1998 (WMO; WHO, 2015), em Brisbane, Austrália ${ }^{9}$, entre 1996 e 2004 (WANG et al., 2012) e em Vitória, também na Austrália, em 2009 e 2014 (YENNETI et al., 2017). As projeções indicam que no Brasil também haverá aumento das mortes ligadas ao calor (GUO et al., 2018). O aquecimento urbano intensifica os impactos de eventos extremos (BOWLER et al., 2010; DUARTE et al., 2015; YENNETI et al., 2017), porém dados sobre a influência dos efeitos da ilha de calor na associação entre onda de calor e mortalidade ainda não estão disponíveis (GUO et al., 2018).

Os mais vulneráveis aos efeitos das altas temperaturas na saúde são os idosos, as crianças pequenas, as pessoas com alguma doença crônica, a população de baixa renda e as pessoas que trabalham ao ar livre (YENNETI et al., 2017).

As cidades podem se preparar para eventos extremos de calor, desenvolvendo planos emergenciais e criando "cooling places", locais de acesso público, dotados ou não de ar condicionado que recebem a população em situações de emergência por calor. No entanto, é necessário que também adotem medidas de longo prazo, com o uso de vegetação e água no ambiente urbano, e diferentes materiais de revestimento, utilizando soluções naturais ou tecnológicas, para de fato diminuírem as temperaturas urbanas e assim o uso de energia para resfriamento das edificações e os gastos com saúde (YENNETI et al., 2017), além de proporcionar um ambiente urbano de melhor qualidade para as pessoas.

De forma genérica, as estratégias para mitigação dos efeitos do aquecimento urbano poderiam ser divididas em dois grupos: estratégias para diminuir o ganho de calor e

\footnotetext{
9 Na Austrália estima-se que eventos extremos de calor tenham matado mais pessoas do que qualquer outro evento climático extremo (Coates et al., 2014, apud Yenneti et al., 2017).
} 
estratégias para aumentar as perdas. O primeiro grupo inclui o uso de materiais mais reflexivos e estratégias de sombreamento. O segundo grupo inclui estratégias de aumento da evapotranspiração e da ventilação.

O uso de vegetação para diminuir as temperaturas urbanas é proposto por diversos pesquisadores e adotado por várias cidades como estratégia efetiva, simples e barata para diminuir as temperaturas urbanas (ADAMS; SMITH, 2014; KATZSCHNER, 2010; SANTAMOURIS; KOLOKOTSA, 2016; STONE; VARGO; HABEEB, 2012; TAHA, 1997; TAHA et al., 2014; YENNETI et al., 2017). O aumento da cobertura arbórea também é relatado como medida de adaptação a eventos extremos de calor (GUO et al., 2018). Estratégias que utilizam vegetação poderiam ser incluídas nos dois grupos de estratégias de mitigação, uma vez que o sombreamento proporcionado pela cobertura arbórea diminui a incidência de radiação solar direta nos materiais urbanos, evitando que estes se aqueçam, além de contribuir com o aumento da evapotranspiração, questões que serão detalhadas a seguir.

\subsection{Os papéis da vegetação no microclima urbano}

A presença de vegetação nas áreas urbanas exerce influência sobre diversas variáveis ambientais, tais como: $T_{\text {sup }}$ umidade e $T_{\text {ar, }}$, ventilação, poluição atmosférica, poluição da água e do solo, drenagem, estabilidade dos solos e biodiversidade, além de impactar diretamente a saúde e o bem-estar humano (GIVONI, 1998; HOUGH, 1998; LOMBARDO et al., 2012; NOWAK, 1994; ULRICH et al., 1991; WONG; CHEN, 2009).

A influência da vegetação nas variáveis citadas acima é complexa (ERELL; PEARLMUTTER; WILLIAMSON, 2011) e varia de acordo com a escala de análise (COUTTS, 2015). Em estudo global realizado com imagens de satélite, Li et al. (2015) verificaram que florestas tropicais possuem forte efeito no resfriamento do clima local durante todo o ano, florestas temperadas possuem efeito moderado no resfriamento do clima local durante o verão e no aquecimento do clima local durante o inverno, já as florestas boreais possuem forte efeito de aquecimento do clima local durante o inverno e efeito moderado no 
resfriamento durante o verão. Os parâmetros que mais influenciaram os resultados nesta escala foram o albedo e a evapotranspiração.

Na escala microclimática os efeitos da vegetação dependem da densidade das folhas, dos tipos de folhas e galhos (e.g. folhas pilosas ou lisas, grandes ou pequenas etc.), do porte da vegetação, da disponibilidade de água no solo e de sua localização. Essas características variam conforme as interações solo/vegetação/atmosfera, a idade da planta, a espécie e a época do ano, apresentando interações complexas com a $T_{\text {sup }}$ e a $T_{\text {ar, }}$, estando ligadas fundamentalmente a dois mecanismos: o sombreamento e a evapotranspiração (ADAMS; SMITH, 2014; FERREIRA, 2012; OKE et al., 2017; WONG; CHEN, 2009).

\subsubsection{Sombreamento}

A interceptação da radiação solar pela vegetação, especialmente pela vegetação arbórea, pode ser considerada o principal papel da vegetação na atenuação das temperaturas das superfícies e do ar (ERELL et al., 2011; SHASHUA-BAR e HOFFMAN, 2000). A interceptação da radiação solar evita que esta incida e aqueça as superfícies urbanas. Menos aquecidas, as superfícies liberam menor quantidade de radiação de onda longa, diminuindo o aquecimento do ar (QIU et al., 2013).

A magnitude do sombreamento pode ser determinada pela estrutura do dossel vegetal, seu índice de área foliar (IAF) e a forma como estão distribuídas as aberturas geométricas das copas, ou gap fraction (SHINZATO, 2014).

É importante ressaltar que em pequenos dosséis vegetais ou em situações de velocidade do vento elevadas, é possível que a $T_{\text {ar }}$ medida abaixo do dossel seja representativa da área adjacente, não sendo possível, portanto, perceber os efeitos da vegetação na $T_{a r}$. Nesses casos, em situações urbanas, o maior impacto dar-se-ia pelo sombreamento das superfícies e do corpo dos pedestres, o que eliminaria a principal fonte de ganho de calor do corpo humano em áreas abertas, contribuindo substancialmente para o conforto térmico (ERELL et al., 2011). 


\subsubsection{Evapotranspiração}

A perda de água para a atmosfera sob a forma de vapor consome a maior parte da radiação absorvida pelas folhas, aumentando o calor latente ao invés do calor sensível. Nesse processo, ocorre o resfriamento das folhas e do ar ao redor delas (GIVONI, 1998; BOWLER et al., 2010). A intensidade da evapotranspiração está diretamente relacionada à disponibilidade de água no solo (ERELL et al., 2011; SHINZATO, 2014). Na presença de água irrestrita este processo pode provocar um resfriamento significativo, porém, em áreas urbanas, não raro o suprimento de água para o sistema radicular é restrito, os estômatos estão bloqueados por partículas de poluição, ou a carga de calor é excessivamente alta, o que provoca o fechamento dos estômatos, fatores que reduzem ou inibem a evapotranspiração (ERELL et al., 2011).

De acordo com Erell et al. (2011) diversas pesquisas relatam a redução da $T_{\text {ar }}$ em seu entorno, o que com frequência é atribuído diretamente à evapotranspiração das folhas do dossel. Porém, o autor alerta para o fato de que a fotossíntese ocorre principalmente nas folhas expostas à radiação solar direta, localizadas no topo do dossel, sendo assim, boa parte da transferência de vapor ocorre acima das árvores, tendo pouca interferência no ar próximo à superfície. Abaixo do dossel haverá influência da evaporação do solo. Em simulações microclimáticas com o software ENVI-met, Shinzato (2014) verificou que o efeito conjunto do sombreamento das copas e da evaporação do solo bem irrigado (umidade de $90 \%$ na camada superficial) resultou em diferenças de até $23,8^{\circ} \mathrm{C}$ na $\mathrm{T}_{\text {sup }}$ quando comparada com a temperatura do asfalto sombreado pelo mesmo dossel vegetal na cidade de São Paulo.

\subsubsection{Efeitos combinados}

Bowler et al. (2010), ao compilarem diferentes estudos sobre a influência de intervenções como plantio de árvores e criação de parques nas temperaturas do ar das áreas urbanas, verificaram que a maioria dos estudos confirma que locais dotados de vegetação podem apresentar temperaturas menores do que locais não arborizados. A sombra gerada pelas árvores demonstrou ser um fator importante na redução das temperaturas do ar; entretanto, também foram verificadas temperaturas menores em áreas com vegetação de pequeno porte (arbustiva e herbácea), o que sugere que o resfriamento evaporativo 
pode desempenhar papel significativo em alguns casos. A vantagem da vegetação arbórea em relação à arbustiva e herbácea, além do sombreamento, é que suas raízes conseguem acessar água em camadas mais profundas do solo (COUTTS, 2015), o que em ambientes com pouca disponibilidade hídrica, contribui tanto com a saúde da vegetação, quanto com uma maior evapotranspiração.

Em determinadas situações urbanas, devido à compacidade do subsolo, à existência de infraestruturas como rede de drenagem, subsolos de edificações etc., as raízes da vegetação arbórea podem ser superficiais, o que compromete não apenas sua capacidade de evapotranspiração como também sua estabilidade.

Além do sombreamento e da evapotranspiração, a vegetação também intercepta a radiação de onda longa emitida pelas superfícies urbanas e pela atmosfera, fatores que em conjunto contribuem para que o ar abaixo do dossel não se aqueça com a mesma magnitude do que em áreas sem a cobertura vegetal (ERELL et al., 2011; DUARTE, 2015).

A proximidade da vegetação com as edificações também pode diminuir a incidência de radiação solar direta nas fachadas, além dos efeitos na $T_{\text {ar }}$ descritos acima, reduzindo o consumo de energia para resfriamento (GIVONI, 1998). Deve-se atentar, porém, para que o arranjo de plantio não impeça a adequada circulação dos ventos e, em climas frios, não obstrua totalmente o acesso à radiação solar permitindo o aquecimento passivo da edificação.

A Figura 5 mostra as interações radiativas e energéticas de um cânion urbano com e sem vegetação, de dia e à noite. Durante o dia, o balanço de energia é governado pela radiação solar. A reflexão ou a absorção da radiação incidente e seu armazenamento, dependerá das características de cada superfície. Na situação sem vegetação (Figura 5A) o fluxo de calor latente é nulo, assim, toda radiação incidente será absorvida ou refletida pelas superfícies. Neste esquema as coberturas possuem admitâncias mais baixas que as paredes e o solo pavimentado, por isso o calor armazenado é menor, porém o fluxo de calor sensível durante o dia é maior uma vez que estas se aquecem com maior facilidade. Dentro do cânion ocorrem múltiplas reflexões da radiação solar direta, o que aumenta a absorção geral da radiação pelas faces do cânion (quando comparadas com superfícies isoladas), incluindo superfícies sombreadas pelos edifícios. Na situação com vegetação 
(Figura 5B) a incidência da radiação solar diretamente sobre paredes e pavimento é bloqueada pela vegetação, diminuindo, portanto, os fluxos de calor sensível. A radiação incidente na vegetação é usada pelas plantas no processo de fotossíntese, que insere o fluxo de calor latente no balanço por meio da evapotranspiração. Este processo diminui o aquecimento do ar abaixo do dossel (Figura 5B). À noite (Figura 5C e D), as coberturas esfriam com maior rapidez do que as demais superfícies, tanto pelo fato do estoque de calor acumulado ser menor, quanto pelo maior FVC. Paredes e piso perdem o calor acumulado durante o dia, aquecendo o ar a seu redor. A presença de vegetação pode dificultar a perda de calor das superfícies durante a noite pela menor visão do céu e pela diminuição da velocidade do ar, fazendo com que a $T_{a r}$ abaixo do dossel não caia tanto, diminuindo a amplitude térmica em relação à situação sem vegetação (COUTTS, 2015; OKE et al., 2017).

A redução dos ganhos de calor pelas paredes e coberturas não sombreadas pela vegetação arbórea poderia ser conseguida por meio da utilização de tetos e paredes verdes.
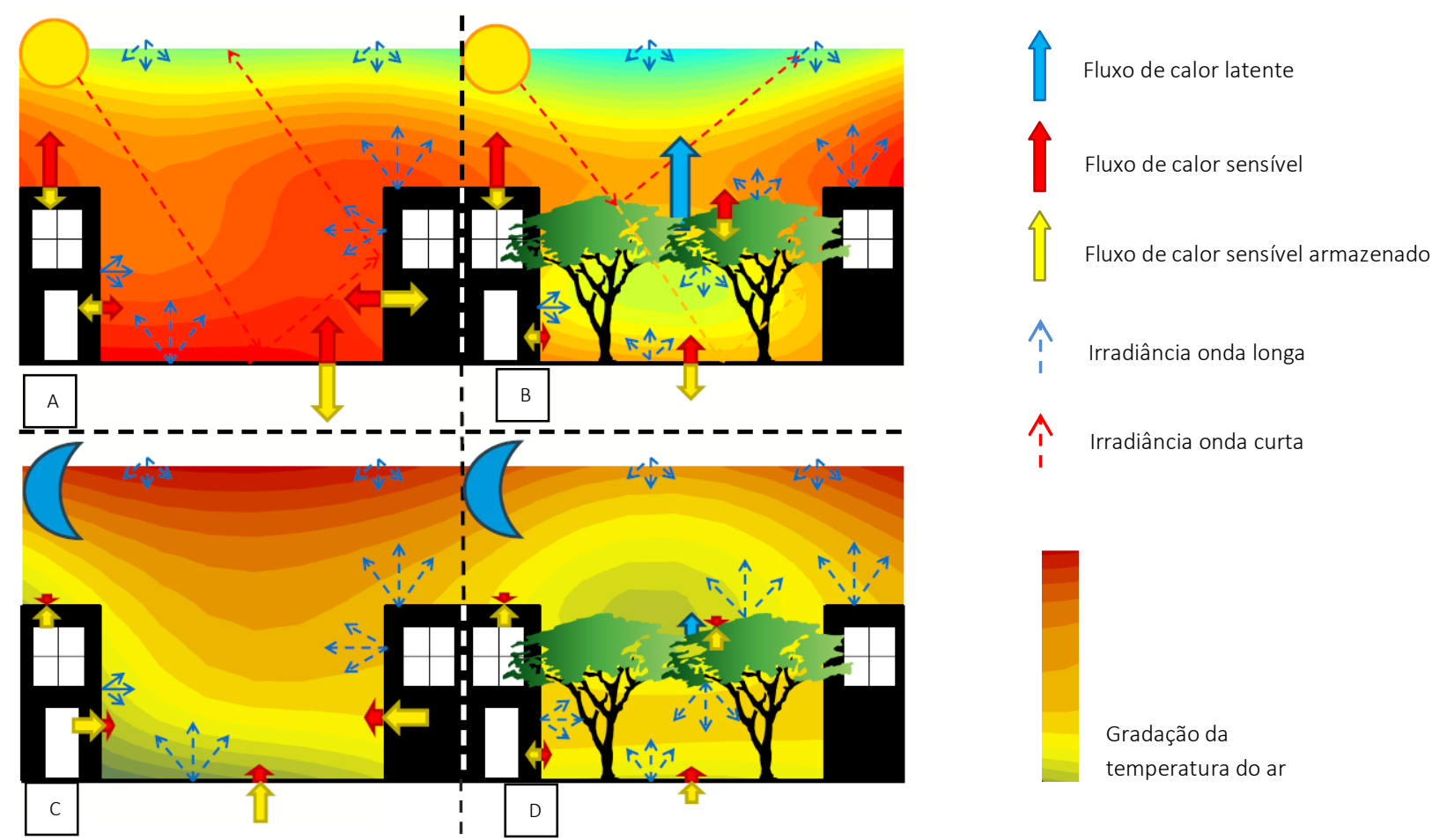

Figura 5. Interações radiativas e energéticas do microclima urbano diurnas ( $A$ e $B$ ) e noturnas ( $C$ e $D$ ) para uma rua sem vegetação (A e C) e com vegetação (B e D). Fonte: Adaptado de Coutts (2015) e Oke et al. (2017). 


\subsubsection{Extensão dos efeitos}

A relação entre a extensão dos efeitos da vegetação para além da área abaixo do dossel tem sido objeto de investigação de diferentes pesquisadores (BOWLER et al., 2010; GIVONI, 1998; HONJO; TAKAKURA, 1990; MENDES, 2012; SHASHUA-BAR; HOFFMAN, 2000; SHINZATO, 2014). Givoni (1998), em medições realizadas em um parque na cidade de Haifa, Israel, verificou redução de $1,5^{\circ} \mathrm{C}$ na $T_{\text {ar }}$ com extensão desses efeitos por, no máximo, 150m. Honjo e Takakura (1990) verificaram extensão de 300 a 400m no sentido do vento. Shashua-Bar e Hoffman (2000) verificaram extensão de 110m em Tel-Aviv e Shinzato (2014) verificou extensão de $5 \mathrm{~m}$, sob condições de baixa velocidade do vento $(1 \mathrm{~m} / \mathrm{s})$, em simulações paramétricas com diferentes dosséis vegetais para a cidade de São Paulo. Todos os resultados foram obtidos para alturas entre 1 e $2 \mathrm{~m}$ acima do solo.

Apesar da variação dos resultados encontrados em relação à extensão dos efeitos das áreas verdes urbanas, que também dependerão da velocidade e direção do vento, podese dizer que estes efeitos são locais.

Assim, é mais significativo para o clima das áreas urbanas um maior número de áreas verdes com dimensões reduzidas do que poucas áreas verdes de grandes dimensões. Wong e Chen (2009) salientam que, do ponto de vista do planejamento, pode-se considerar que pequenas áreas verdes estrategicamente implantadas ao redor das edificações devem ser largamente incentivadas, o que não significa que grandes parques não sejam efetivos em termos de melhora do microclima urbano, mas em ambientes densamente ocupados, grandes áreas verdes podem ser consideradas um luxo, especialmente em locais de rápida expansão urbana.

O efeito da vegetação no clima das áreas urbanas depende ainda da relação entre a área construída e área coberta por vegetação, pública ou privada. Em cidades com alta densidade construída, com altas taxas de impermeabilização e consequentemente com pouco espaço disponível para a vegetação, o efeito das plantas na $T_{a r}$ pode ser pequeno (GIVONI, 1998). Giridharan et al. (2008), ao investigarem a influência da vegetação no arrefecimento da $T_{a r}$ na cidade de Hong Kong, concluíram que a mera introdução de vegetação em uma cidade com alta densidade construída e composta de edifícios altos não gera reduções significativas na $T_{a r}$ externa, sendo necessário considerar outras 
variáveis, tais como fator de visão de céu e altitude do ponto avaliado para que resultados mais tangíveis sejam alcançados. Ng et al. (2012) verificaram, também para Hong Kong, que seria necessário que $33 \%$ da área urbana da cidade fosse coberta por vegetação arbórea para que a $T_{\text {ar }}$ na altura do pedestre fosse reduzida em $1^{\circ} \mathrm{C}$.

Apesar da pequena redução na $T_{\text {ar }}$ em regiões muito adensadas, pode haver significativa redução da $T_{\text {sup }}$ o que diminui a emissão de radiação de onda longa e melhora o conforto do pedestre. Em simulações computacionais com o software ENVI-met para a cidade de São Paulo, Duarte (2016) verificou que a introdução de vegetação em um cânion urbano teve efeito limitado na redução da $T_{\text {ar }}$ (até $1,1^{\circ} \mathrm{C}$ ), porém significativo efeito na redução da $\mathrm{T}_{\text {sup }}$ (até $12^{\circ} \mathrm{C}$ ). O mesmo tipo de estudo para a cidade de Thessaloniki, Grécia, mostrou reduções de menos de $1^{\circ} \mathrm{C}$ na $T_{\text {ar }}$, porém de até $20^{\circ} \mathrm{C}$ na $T_{\text {sup }}$ (CHATZIDIMITRIOU; CHRISSOMALLIDOU; YANNAS, 2005).

De acordo com Duarte (2016) diferenças dessa magnitude tanto na $T_{\text {ar }}$ como na $T_{\text {sup }}$ são percebidas pelo corpo humano, podendo afetar a sensação de conforto térmico, expressas por índices como PET e ou TEP - Temperatura Equivalente Percebida (MONTEIRO; ALUCCI, 2011), que podem apresentar redução de $10^{\circ} \mathrm{C}$ sob a sombra do dossel vegetal. Assim, pode-se concluir que, apesar de aparentemente pequenos, os efeitos da vegetação no microclima urbano e no conforto humano são significativos.

Além dos benefícios microclimáticos e de conforto humano, áreas dotadas de vegetação como parques e praças, desempenham importante papel social e psicológico, favorecendo a prática de atividades físicas, o contato com a natureza e o convívio social (BILIBIO, 2011; GIVONI, 1998; LOUV, 2006; ULRICH et al., 1991).

O papel das áreas verde urbanas é também relevante para a diminuição dos poluentes atmosféricos (NOWAK, 1994), remoção ou imobilização de contaminantes presentes no solo (MORINAGA, 2007), retenção e infiltração da água de chuva (MAGNOLI, 1982), diminuição da velocidade do escoamento superficial (EPA 2003) e como suporte para a biodiversidade. 


\subsubsection{Desafios para sobrevivência da vegetação em área urbana}

A vegetação urbana está exposta a pressões biológicas, físicas e químicas que dificultam seu crescimento e sobrevivência no ambiente urbano (SPIRN, 1995). Frequentemente a vegetação arbórea urbana não consegue viver o tempo necessário para que atinja o porte capaz de propiciar os benefícios citados anteriormente.

Árvores urbanas, especialmente as isoladas, podem estar expostas à intensa radiação de onda curta, direta e refletida pelas superfícies, e de onda longa, devido à emissão das superfícies impermeáveis, sobretudo asfalto e concreto. Altas cargas de calor precisariam ser dissipadas pela árvore, e caso haja limitação da água disponível no solo, esse processo ficará prejudicado, interferindo em sua saúde. Em outros casos a quantidade de radiação pode ser insuficiente devido à sombra dos edifícios (COUTTS, 2015).

A concentração de materiais particulados $\left(\mathrm{PM}_{10}\right)$, por exemplo, é um dos fatores que dificulta o crescimento das árvores. Em estudo realizado com a espécie Tipuana tipu na cidade de São Paulo Locosselli et al. (2018) verificaram que árvores expostas a altas concentrações de $\mathrm{PM}_{10}\left(0.60-0.80 \mu \mathrm{g} / \mathrm{m}^{3}\right)$ apresentaram taxa de crescimento menor do que as expostas a médias e baixas concentrações. Já a concentração de $\mathrm{CO}_{2}$ pode beneficiar o crescimento da vegetação (COUTTS, 2015).

A Figura 6 exemplifica outro tipo de interferência de áreas construídas na vegetação. Após oito anos da inauguração do Parque do Trote ${ }^{10}$, em São Paulo, pôde-se perceber o raleamento das copas do conjunto arbóreo localizado à direita da imagem. Ambos os conjuntos assinalados possuem a mesma idade, porém, durante a implantação do Parque foi executado pavimento ao redor das árvores do conjunto à direita. O conjunto à esquerda permaneceu com o entorno completamente permeável. A diminuição da área de infiltração deixou as árvores mais vulneráveis ao ataque de pragas e doenças, tendo sido constatada alta incidência de mosca branca, que provocou intenso desfolhamento e posteriormente a queda de galhos secos (informação verbal) ${ }^{11}$.

\footnotetext{
${ }^{10}$ O Parque foi inaugurado em 2006 e a imagem adquirida em 2014.

11 Informação fornecida via email por Priscilla Cerqueira, engenheira agrônoma, funcionária da Secretaria do Verde e do Meio Ambiente da Prefeitura de São Paulo em 15/10/2018.
} 


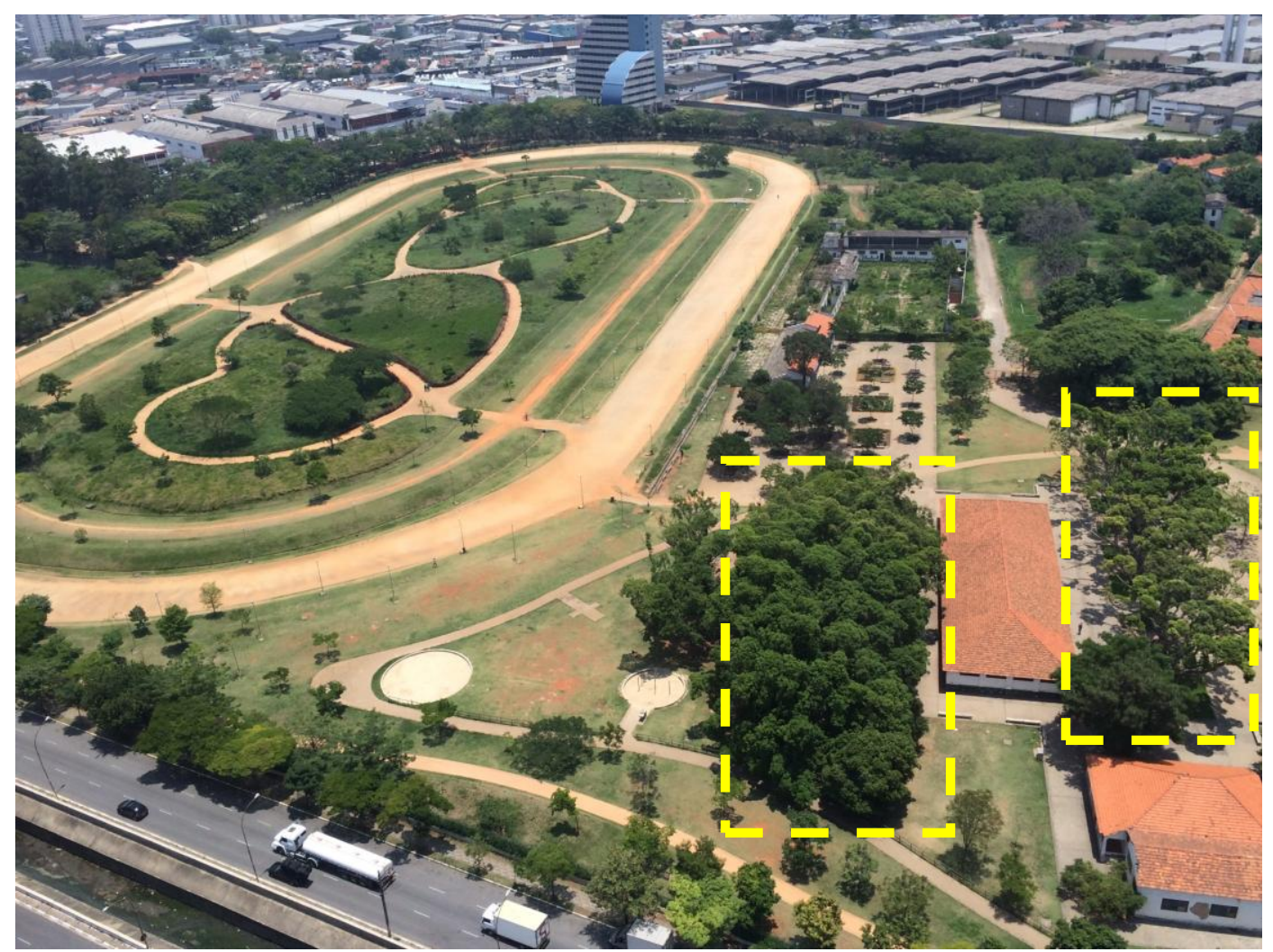

Figura 6. Parque do Trote, São Paulo. Raleamento das copas do conjunto arbóreo localizado à direita da imagem devido à implantação de piso ao redor das árvores. Fonte: Banco de imagens Depave-5 SVMA.

A vegetação urbana também pode ser vulnerável às alterações provocadas pelas mudanças climáticas globais, tais como: alterações nas temperaturas, na quantidade e regularidade de chuvas, na ocorrência dos períodos secos e chuvosos, nos eventos de cheias, na salinidade da água e do solo devido ao aumento do nível do mar, na concentração de poluentes, na quantidade de insetos e de espécies invasoras etc. (ORDÓÑEZ; DUINKER, 2014).

Dessa forma, melhorar o microclima urbano por meio do aumento da cobertura vegetal exigirá também a criação de condições para que a vegetação se desenvolva plenamente e tenha acesso à água e aos nutrientes necessários para tal no clima urbano atual e futuro. 


\section{TÉCNICAS PARA A OBSERVAÇÃO DA SUPERFÍCIE URBANA}

Este capítulo apresenta as técnicas de observação e descrição da temperatura de superfície $\left(T_{\text {sup }}\right)$, da vegetação e da morfologia urbana na escala de análise da pesquisa, a escala local. São apresentados também resultados de outros trabalhos que utilizaram técnicas semelhantes para posterior comparação com os resultados desta pesquisa.

\subsection{Técnicas para observação da temperatura de superfície}

A forma de aferição das variáveis que caracterizam o clima urbano depende em grande medida da escala de análise. Na escala de análise microclimática as variáveis comumente abordadas ( $T_{a r}$, umidade relativa do ar, velocidade dos ventos etc.), são medidas por estações meteorológicas fixas ou com o uso de transectos. Na escala local, a utilização das mesmas variáveis usadas na escala microclimática dependeria de uma rede densa de estações com as mesmas características e equipamentos, o que não se configura como realidade para muitas áreas urbanas, especialmente as localizadas em países em desenvolvimento.

Diante da dificuldade de usar a $T_{\text {ar }}$ muitos trabalhos utilizam a $T_{\text {sup }}$ como variável climática a ser estudada, impulsionados também pelas possibilidades de medição com o uso de sensores remotos que conseguem captar simultaneamente áreas de estudo de grandes dimensões e pelas melhores correlações que esta variável apresenta com diferentes usos do solo (HU; JIA, 2010; WENG, 2009).

A $T_{\text {sup }}$ é uma variável importante nos estudos de climatologia urbana, pois: modula a $T_{\text {ar }}$ das camadas mais baixas da atmosfera, é central para o balanço de energia das superfícies, ajuda a determinar a temperatura interna das edificações e afeta as trocas de energia que interferem no conforto da população urbana (VOOGT; OKE, 2003).

O estudo da $T_{\text {sup }}$ pode ser realizado por meio de sensores termais portáteis ou remotos, acoplados em aeronaves ou em satélites. Sensores portáteis fornecem melhor resolução espacial, porém com menor área de abrangência. Permitem escolher a superfície a ser 
estudada uma vez que o ângulo de visada do sensor é determinado pelo usuário, em que pesem as alterações na resposta termal provocadas pelo ângulo de visão e que serão abordadas neste capítulo. A Figura 7 e a Figura 8 exemplificam o tipo de imagem obtida com um sensor termal portátil. Tais figuras são apresentadas apenas com objetivo ilustrativo. A utilização de imagens termais de alta resolução é complexa e demanda precisa definição da emissividade dos alvos imageados.

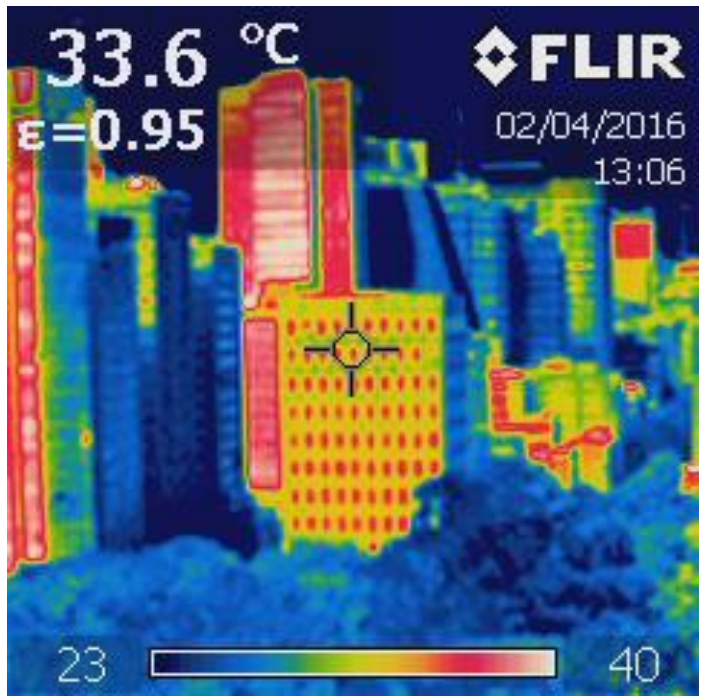

Figura 7. Imagem termal do Parque Tenente Siqueira Campos - Trianon (São Paulo) em primeiro plano e edifícios ao fundo. Câmera termográfica digital FLIR i40. Fonte: imagem da autora.

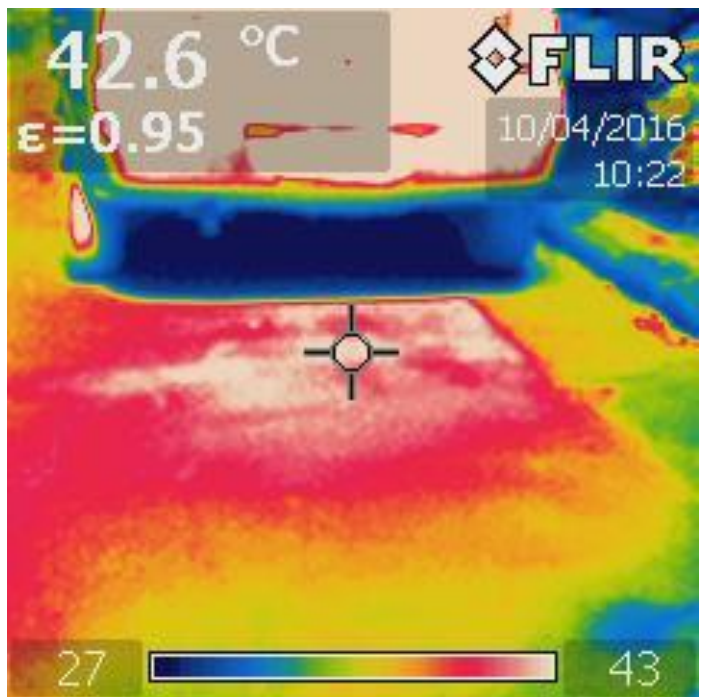

Figura 8. Imagem termal de um veículo estacionado na Rua Peixoto Gomide (São Paulo). Câmera termográfica digital FLIR i40. Fonte: imagem da autora.

O avanço das tecnologias de sensoriamento remoto $(S R)^{12}$ permitiu ser possível a observação da $T_{\text {sup }}$ a partir de aeronaves e satélite. Esse tipo de imagem termal apresenta menor resolução espacial, porém maior área de abrangência, permitindo a aferição da $T_{\text {sup }}$ simultaneamente em um grande número de superfícies (Figura 9 e Figura 10).

\footnotetext{
${ }^{12}$ Nesse trabalho as menções ao termo Sensoriamento Remoto (SR) referem-se ao sensoriamento remoto orbital, ou seja, aquele que utiliza sensores acoplados a satélites.
} 


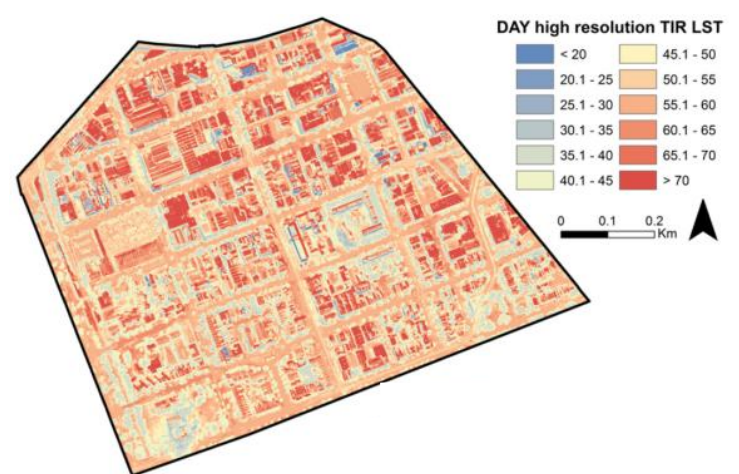

Figura 9. Imagem termal de alta resolução captada por sensor acoplado em aeronave. Resolução espacial 0,5m. Fonte: Coutts et al. (2016)

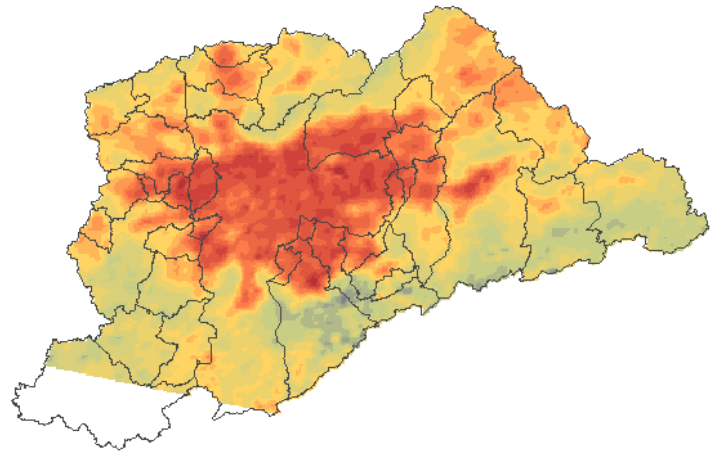

Figura 10. Imagem termal da RMSP captada pelo sensol MODIS $^{13}$ acoplado ao satélite Aqua. Resolução espacial $250 \mathrm{~m}^{14}$. Fonte: Ferreira e Duarte (2018).

Em estudo realizado na região de Melbourne, Austrália, Coutts et al. (2016) avaliaram a capacidade de identificação de áreas com altas temperaturas do ar (hotspots) por meio de imagens de $T_{\text {sup }}$ obtidas com sensores de altíssima resolução espacial, ou VHR, com 0,5m de resolução, acoplados em aeronaves. O objetivo da avaliação era informar o planejamento urbano local sobre a adequação desse método para a identificação de hotspots. Apesar de conseguirem captar locais com alta $\mathrm{T}_{\text {sup }}$ com bastante precisão, os autores obtiveram melhor correlação entre a $T_{\text {sup }}$ e a $T_{\text {ar }}$ quando o dado de alta resolução foi agregado, "piorando" a resolução da imagem. Assim, concluíram que para estudos urbanos em escala local as imagens termais de resolução maiores que $30 \mathrm{~m}$ são mais indicadas para a definição das áreas com maiores $T_{\text {ar }}$ que necessitam de intervenção por parte do planejamento urbano local.

Para Li et al. (2013) o SR termal feito a partir de satélites configura-se como a única opção para aferição da $T_{\text {sup }}$ de forma global, com resolução temporal suficientemente alta, apresentando ainda a possibilidade de trabalhar com valores médios ao invés de medidas pontuais.

\footnotetext{
${ }^{13}$ MODIS: Moderate Resolution Imaging Spectroradiometer

${ }^{14}$ Dados MODIS originalmente adquiridos com resolução espacial de $1 \mathrm{~km}$ e reamostrados para $250 \mathrm{~m}$.
} 


\subsubsection{Sensoriamento remoto em áreas urbanas}

O SR terrestre tem sido tradicionalmente utilizado pelas áreas militares e das ciências da terra (eg. Agronomia, Geologia, Ciências Florestais etc.), sendo que a utilização para estudos urbanos é recente; fóruns acadêmicos sobre o tema tiveram início apenas em 1995. Estudos de geometria e morfologia urbana, de ocupação do solo e de dinâmicas e consequências da urbanização para as alterações climáticas globais estão entre os mais recorrentes na área (YANG, 2011).

Dentre as vantagens para utilização do SR em áreas urbanas destacam-se: a possibilidade de estudar simultaneamente grandes áreas a um custo baixo, oferecendo uma alternativa à coleta de dados em solo que normalmente é muito custosa ou impraticável para grandes áreas de estudo; o fornecimento de informações de faixas do espetro eletromagnético não visível, acrescentando importantes informações ao levantamento de campo de estudos urbanos que normalmente são bastante focados em interpretações visuais da realidade; a disponibilidade de utilização de dados passados e a confecção de séries temporais, que oferece uma perspectiva histórica dos processos ou atributos urbanos; a abrangência global das imagens e a grande variedade de resoluções espaciais e temporais, que abrange as diferentes escalas de trabalho dos pesquisadores e planejadores urbanos (desde a escala local, com imagens de resolução espacial de frações de metros, até escalas regionais, com imagens de resolução espacial de quilômetros); a possibilidade de integração com sistemas de informações geográficas (SIG) e o cruzamento com dados de população, ocupação, renda etc. (FLORENZANO, 2007; JENSEN, 2009; YANG, 2011).

As limitações associadas à utilização de SR em áreas urbanas englobam: a dificuldade de interpretação das imagens devido à complexidade do ambiente urbano, que mescla áreas pavimentadas de diferentes materiais com edificações de diversas alturas e coberturas vegetais de diferentes tipos e densidades e a possibilidade de introdução de erro humano, uma vez que as imagens devem ser tratadas e processadas para interpretação, o que também acontece com dados levantados em campo (FLORENZANO, 2007; JENSEN, 2009; YANG, 2011). Soma-se a estes fatores a dificuldade no tratamento das imagens, que 
muitas vezes não é trivial, principalmente para arquitetos e planejadores urbanos que não possuem esse tipo de formação acadêmica em sua grade curricular padrão.

\subsubsection{Observação da temperatura de superfície por sensores termais remotos}

A observação da $T_{\text {sup }}$ por sensores termais baseia-se na medição da radiação eletromagnética (REM) emitida por corpos e superfícies.

A REM é gerada por diferentes mecanismos: alterações nos níveis de energia de elétrons, aceleração de cargas elétricas, diminuição de substâncias radioativas e movimento térmico de átomos e moléculas. As reações nucleares que ocorrem no Sol, por exemplo, produzem um espectro completo da $\operatorname{REM}^{15}$ (Figura 11) que é transmitida até a atmosfera terrestre sem sofrer alterações significativas. A partir de então ocorrem uma série de interações da REM com a atmosfera terrestre (reflexões, absorções, espalhamentos etc.) até que esta incida sobre objetos na superfície (CAMPBELL; WYNNE, 2011).

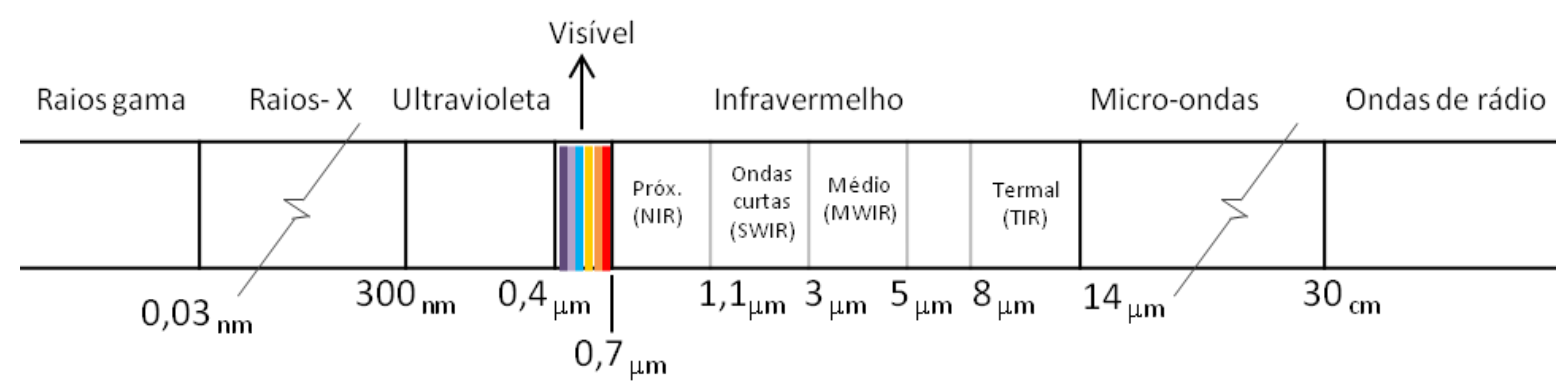

Figura 11. Espectro eletromagnético. Fonte: Adaptado de Campbell e Wynne (2011) e Schowengerdt (2007).

A interação entre a REM incidente e os objetos dependerá das propriedades destes, conforme discutido no capítulo 1 para o caso de um cânion urbano, porém, independente de suas características todos os objetos, naturais ou artificiais, com temperatura acima do zero absoluto (OK ou $-273,15^{\circ} \mathrm{C}$ ) emitem REM em função de sua temperatura (CAMPBELL; WYNNE, 2011; JENSEN, 2009).

A REM emitida por um objeto é denominada fluxo radiante, sendo a intensidade desse fluxo a temperatura radiante $\left(T_{\text {rad }}\right)$. A correlação entre a temperatura real ( $\left.T_{\text {real }}\right)$ de um objeto e a $T_{\text {rad }}$ usualmente é alta e positiva ${ }^{16}$, o que permite a utilização de radiômetros

\footnotetext{
${ }^{15}$ Os limites das divisões do espectro da REM não são consensuais e diferenças de valores podem ser encontradas dependendo da referência adotada, especialmente em relação aos intervalos do infravermelho.

16 Exceto para objetos compostos por vidro e metal.
} 
remotos para medir a $T_{\text {rad }}$ e obter a $T_{\text {real. }}$ Apesar de alta, esta correlação não é perfeita, visto que objetos distintos emitem radiação de forma distinta, sendo a $T_{\text {rad }}$ sempre um pouco inferior à $T_{\text {real. }}$ (JENSEN, 2009).

O coeficiente que descreve a forma como um corpo emite radiação é a emissividade $(\varepsilon)$. Dois objetos com a mesma $T_{\text {rad }}$ podem apresentar $T_{\text {real }}$ distinta devido à emissividade, que é influenciada, segundo Jensen (2009) pelos seguintes fatores: $\operatorname{cor}^{17}$, composição química, rugosidade superficial, umidade $^{18}$, compactação (que pode afetar a umidade), campo de visada do sensor, ângulo de visada do sensor e comprimento de onda.

Em imagens do infravermelho termal (IVT) obtidas por sensores remotos, objetos com emissividades baixas, como coberturas metálicas, aparecerão com $T_{\text {rad }}$ também baixa, o que não significa que sua $T_{\text {real }}$ também seja baixa, como verificado por Sousa e Ferreira (2012) em estudo realizado na cidade de Goiânia. Assim, a emissividade deve ser considerada para que equívocos de interpretação não ocorram.

A relação entre $T_{\text {rad }}$ e $T_{\text {real }}$ é dada pela seguinte equação (SABINS, 1996):

$\mathrm{T}_{\mathrm{rad}}=\varepsilon^{1 / 4} \mathrm{~T}_{\text {real }}$ Equação 1

A Tabela 1 exemplifica o impacto da emissividade nas temperaturas radiantes e reais.

17 Objetos escuros absorvem mais energia e pelo equilíbrio térmico emitem mais energia, apresentando, portanto, maior emissividade do que objetos claros.

18 Quanto maior a umidade, maior a capacidade de absorver e emitir energia.

\section{2}


Tabela 1. Emissividade, temperatura radiante e verdadeira de diferentes materiais. Fonte: Adaptado de Jensen (2009) e Frota e Schiffer (2001).

\begin{tabular}{l|l|l|l} 
Material & Emissividade $(\varepsilon)$ & $\mathrm{T}_{\text {rad }}\left({ }^{\circ} \mathrm{C}\right)$ & $\mathrm{T}_{\text {real }}\left({ }^{\circ} \mathrm{C}\right)$ \\
\hline Corpo negro teórico & 1,00 & 27 & 27 \\
\hline Água destilada & 0,99 & 26,2 & 27 \\
\hline Vegetação & 0,98 & 25,5 & 27 \\
\hline Tijolo/Telha cerâmica & 0,95 & 23,2 & 27 \\
\hline
\end{tabular}

Além da emissividade, as interações da REM emitida pelos objetos terrestres com a atmosfera (Figura 12 e Figura 13) também deve ser considerada quando utilizadas medições via satélites (WAN, 1999). Satélites que já disponibilizam os dados de $T_{\text {sup }}$ em produtos específicos, como o Terra-MODIS e o Aqua-MODIS, utilizam dados de emissividade, absorção e dispersão da radiação pela atmosfera e quantidade de radiação solar para calcular a $\mathrm{T}_{\text {sup }}(\mathrm{WAN}, 1999)$.

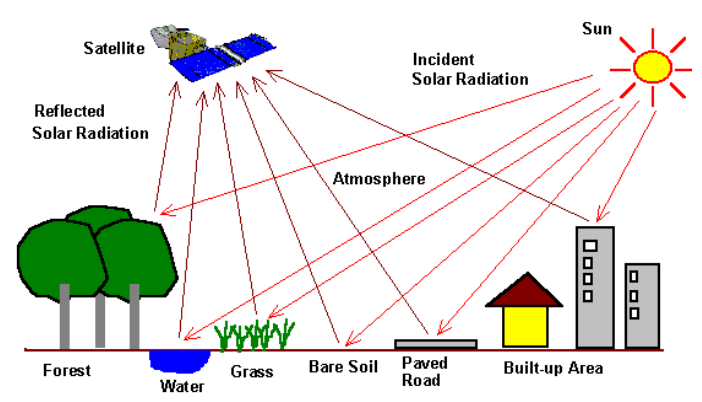

Figura 12. Interação da radiação medida por um satélite com diferentes materiais e com a atmosfera durante o dia. Fonte: CRISP [s.d]

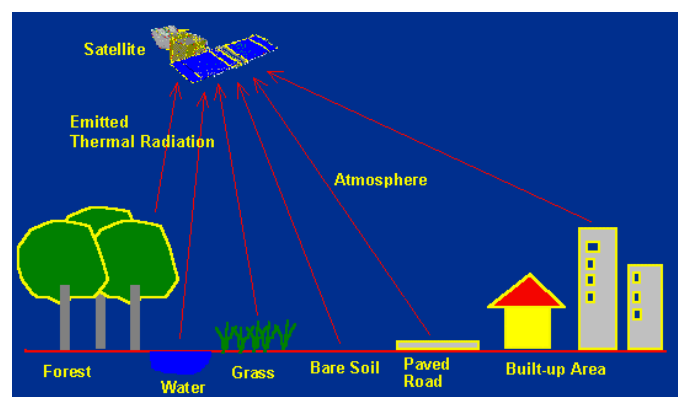

Figura 13. Interação da radiação medida por um satélite com diferentes materiais e com a atmosfera durante a noite. Fonte: CRISP [s.d]

Os satélites conseguem captar a REM do IVT pois esta é apenas parcialmente absorvida pela atmosfera. Pode-se dizer que a atmosfera é "transparente" para este tipo de radiação, ou que existem janelas atmosféricas (Figura 14) que permitem a passagem de determinados comprimentos de onda. Normalmente sensores termais acoplados em satélites registram dados na região do espectro compreendida entre 10,5 e 12,5 $\mu \mathrm{m}$ (JENSEN, 2009). Sensores termais acoplados em aeronaves podem registrar toda a região compreendida entre 8 e 14 um pois não são afetados pela absorção da camada de ozônio que ocorre entre 9 e $10 \mu \mathrm{m}$ (SABINS, 1996). 


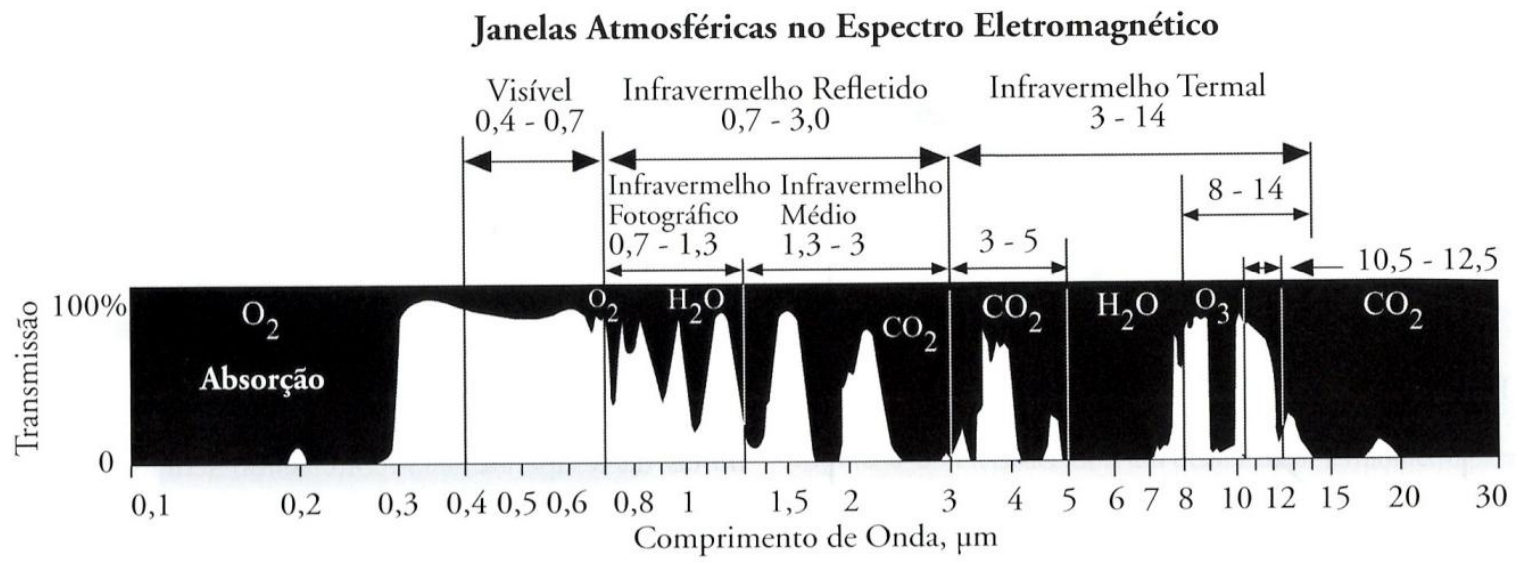

Figura 14. Janelas atmosféricas no espectro eletromagnético. Fonte: JENSEN, 2009.

Além dos fatores mencionados de importância para o cálculo da $T_{\text {sup }}$ a partir da REM do IVT captada pelos sensores remotos, a interpretação das imagens termais também deve levar em conta alguns fatores. As medidas de $T_{\text {sup }}$ incorporam os efeitos das propriedades radiativas e termodinâmicas da superfície, incluindo umidade, admitância e emissividade, além da intensidade da radiação direta e difusa incidente na superfície e os efeitos atmosféricos locais ${ }^{19}$ nas trocas térmicas da superfície (VOOGT; OKE, 2003).

Em áreas urbanas, a heterogeneidade e a estrutura tridimensional tornam o uso do SR termal mais complexo. As superfícies urbanas possuem diferentes orientações, o que influi tanto no ganho quanto na perda de calor, além disso, o ângulo de visão do sensor termal também pode influenciar nos resultados. A esta dependência direcional da medida dá-se o nome de anisotropia (OKE et al., 2017; VOOGT; OKE, 2003). A Figura 15 ilustra o campo de visão de um sensor hipotético. Nesse caso o sensor capta respostas de faces verticais e horizontais em proporções que dependem do ângulo de visada (Field of view FOV) e do ângulo solar.

\footnotetext{
${ }^{19}$ Voogt e Oke (2003) alertam para o fato de que, apesar das correções para os efeitos atmosféricos estarem bem estabelecidas, existe pouca informação disponível para o papel que variações de transmissividade atmosférica podem influenciar no cálculo da TS, fato que poderia impactar sobretudo os estudos de Ilha de calor superficial.
} 


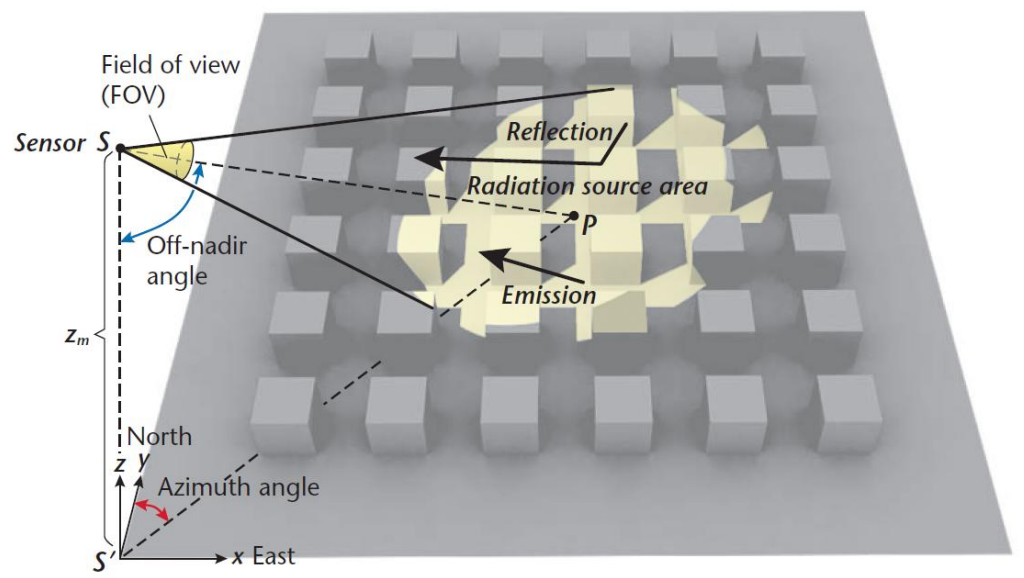

Figura 15. Campo de visão de um sensor hipotético. Fonte: OKE et al., (2017)

O SR do IVT tem sido largamente utilizado como ferramenta para obtenção da $T_{\text {sup }}$ e estudos da ilha de calor urbana (WENG, 2009). O trabalho de Rao (1972) foi o primeiro a avaliar a possibilidade de deteç̧ão desse fenômeno por meio de imagens de satélite. Desde então, diversos trabalhos têm explorado essa possibilidade utilizando diferentes sensores termais para estudos urbanos. Roth, Oke e Emery (1989) e Voogt e Oke (2003) produziram levantamentos sobre o estado da arte de estudos de clima urbano realizados com SR.

A revisão bibliográfica realizada pelo presente trabalho levantou estudos com aplicações práticas em áreas urbanas cujo objetivo fosse examinar correlações entre $T_{\text {sup }}$ e padrões de ocupação urbana e/ou entre $T_{\text {sup }}$ e presença de vegetação ${ }^{20}$.

De maneira geral, a maior parte dos estudos levantados que utilizam SR do IVT para estudos de clima urbano o faz para estudar a ilha de calor superficial baseando-se nas diferenças de temperatura entre áreas urbanas centrais e áreas não urbanizadas adjacentes (FUCKNER; MORAES; FLORENZANO, 2009; ROTH; OKE; EMERY, 1989; SIDIQUI; HUETE; DEVADAS, 2016; SOUSA; FERREIRA, 2012). Alguns estudos exploram o papel de certas características urbanas, como percentual de área impermeável, fator de visão de céu e cobertura arbórea nas respostas termais (HU; JIA, 2010; IMHOFF et al., 2010; SCARANO; SOBRINO, 2015; ZHOU et al., 2014). Mais recentemente, a adoção do conceito de Local Climate Zones (LCZ) (STEWART; OKE, 2012) por parcela significativa dos

\footnotetext{
${ }^{20}$ Os estudos sobre vegetação serão apresentados no item 2.2.
} 
climatologistas urbanos impulsionou estudos que se aprofundam nas diferenças de $T_{\text {sup }}$ das diferentes LCZs de uma mesma cidade (ALEXANDER et al., 2017; CAl et al., 2018; GELETIČ; LEHNERT; DOBROVOLNÝ, 2016). Apesar da existência de séries temporais longas de imagens termais, poucos estudos se dedicaram a explorar tendências temporais da $T_{\text {sup }}$ em áreas urbanas (ALEXANDER et al., 2017).

Os estudos analisados por esta pesquisa apresentam diversos resultados convergentes. De maneira geral, e a despeito do local de análise e do satélite utilizados, a Ilha de calor superficial apresenta maior intensidade no período diurno do verão (IMHOFF et al., 2010; ROTH; OKE; EMERY, 1989; SIDIQUI; HUETE; DEVADAS, 2016; ZHOU et al., 2014). Em cidades com entorno desértico, porém, a llha de calor superficial diurna pode ser negativa (IMHOFF et al., 2010). As $T_{\text {sup }}$ diurnas são maiores em áreas com grande porcentagem de solo ocupada por construções ou impermeabilizado (BARROS; LOMBARDO, 2016; FUCKNER; MORAES; FLORENZANO, 2009; IMHOFF et al., 2010; ROTH; OKE; EMERY, 1989), porém áreas verticalizadas apresentam $\mathrm{T}_{\text {sup }}$ mais amena durante o dia (FUCKNER; MORAES; FLORENZANO, 2009; ROTH; OKE; EMERY, 1989; SOUSA; FERREIRA, 2012), assim como áreas com vegetação arbórea (ALEXANDER et al., 2017; BARROS; LOMBARDO, 2016; COUTTS et al., 2016; FUCKNER; MORAES; FLORENZANO, 2009; HU; JIA, 2010; ROTH; OKE; EMERY, 1989; SOUSA; FERREIRA, 2012; ZHOU et al., 2014).

No Brasil merece destaque o trabalho pioneiro de Lombardo (1985) sobre a ilha de calor na Região Metropolitana de São Paulo. Mais recentemente verificam-se outros trabalhos da mesma autora (BARROS; LOMBARDO, 2016) e estudos para Goiânia (SOUSA; FERREIRA, 2012), além de trabalhos que abordam simultaneamente as cidades do Rio de Janeiro e de São Paulo (FLORES R.; PEREIRA FILHO; KARAM, 2016; FUCKNER; MORAES; FLORENZANO, 2009).

A Tabela 2 sintetiza as principais características e conclusões dos estudos levantados por este trabalho sobre a aplicação do SR do IVT em pesquisas sobre clima urbano. 
Tabela 2. Síntese dos estudos com aplicação do SR do IVT em pesquisas sobre clima urbano.

\begin{tabular}{|c|c|c|c|c|c|c|}
\hline Autores (ano) & $\begin{array}{l}\text { Período } \\
\text { analisado }\end{array}$ & Objeto de estudo & $\begin{array}{l}\text { Local do } \\
\text { estudo }\end{array}$ & Dados utilizados & $\begin{array}{l}\text { Qtde de cenas orbitais } \\
\text { usadas }\end{array}$ & Principais conclusões \\
\hline $\begin{array}{l}\text { Lombardo } \\
\text { (1985) }\end{array}$ & $1980-1982$ & $\begin{array}{l}\text { Ilha de calor (IC) e } \\
\text { Ilha de calor } \\
\text { superficial (IC sup) }\end{array}$ & $\begin{array}{l}\text { Região } \\
\text { Metropolitana } \\
\text { de São Paulo }\end{array}$ & $\begin{array}{l}\text { TIROS e NOAA + } 45 \\
\text { pontos de medição } \\
\text { em solo + mapa de } \\
\text { uso e ocupação do } \\
\text { solo }\end{array}$ & $\begin{array}{l}8 \text { cenas (1: 1980, } \\
3: 1981 \text { e } 4: 1982)\end{array}$ & $\begin{array}{l}\text { Em todas as situações analisadas a IC e a I } C_{\text {sup }} \text { em SP coincidem (na sua conformação) com a definição } \\
\text { proposta por Oke em } 1978 \text { (maiores temperaturas no centro urbano). Intensidade da I } C_{\text {sup }} \text { superior a } 10^{\circ} \mathrm{C} \text {. } \\
\text { Verificou a influência do vento e da concentração de poluentes nesse fenômeno e sua maior intensidade no } \\
\text { período diurno. } T_{\text {sup }} \text { mais altas associadas às áreas densamente construídas e verticalizadas com pouca } \\
\text { cobertura arbórea. Temperaturas mais amenas associadas às áreas arborizadas e próximas a reservatórios } \\
\text { de água. }\end{array}$ \\
\hline $\begin{array}{l}\text { Roth et al. } \\
\text { (1989) }\end{array}$ & $1983-1986$ & $\mathrm{IC}_{\text {sup }}$ & $\begin{array}{l}\text { Vancouver } \\
\text { (Canadá), } \\
\text { Seatle e Los } \\
\text { Angeles } \\
\text { (E.U.A) }\end{array}$ & NOAA AVHRR & 11 cenas & $\begin{array}{l}\mathrm{I} \mathrm{C}_{\text {sup }} \text { mais intensa durante o dia no verão. } T_{\text {sup }} \text { maior em áreas mais densamente construídas com maior } \\
\text { quantidade de pavimentos impermeáveis. } T_{\text {sup }} \text { de áreas verticalizadas mais amena. } T_{\text {sup }} \text { de áreas mais } \\
\text { arborizadas mais amena. } I \mathrm{C}_{\text {sup }} \text { diurna apresenta melhor correlação com ocupação do solo do que noturna. }\end{array}$ \\
\hline $\begin{array}{l}\text { Fuckner et al } \\
\text { (2009) }\end{array}$ & $\begin{array}{l}2002 \text { e } 2006 \\
\text { (SP) } 2003 \text { e } \\
2004 \text { (RJ) }\end{array}$ & $\mathrm{IC}_{\text {sup }}$ & $\begin{array}{l}\text { São Paulo e } \\
\text { Rio de Janeiro } \\
\text { (Brasil) }\end{array}$ & ASTER & 2 cenas/cidade & $\begin{array}{l}\text { SP: Áreas arborizadas apresentam T } T_{\text {sup }} \text { mais amenas. Áreas verticalizadas mais amenas. RJ: Afloramentos } \\
\text { rochosos mais aquecidos, assim como grandes eixos viários. No Rio há forte influência da topografia. }\end{array}$ \\
\hline $\begin{array}{l}\text { Imhoff et al. } \\
\text { (2010) }\end{array}$ & $2003-2005$ & $\begin{array}{l}\text { IC } C_{\text {sup vs. área }} \\
\text { impermeável vs. } \\
\text { NDVI }\end{array}$ & $\begin{array}{l}38 \text { cidades } \\
\text { E.U.A }\end{array}$ & $\begin{array}{l}\text { Aqua MODIS, Landsat } \\
\text { ETM+ e IKONOS }\end{array}$ & Todas as cenas & $\begin{array}{l}\text { IC } C_{\text {sup }} \text { mais intensa durante o dia no verão. E mais intensa em cidades com entorno arborizado. Cidades com } \\
\text { entornos desérticos podem apresentar } I_{\text {sup }} \text { negativas. } T_{\text {sup }} \text { diurnas do verão para todas as cidades mostram } \\
\text { correlação positiva com a área impermeável (exceto deserto). }\end{array}$ \\
\hline $\begin{array}{l}\text { Hu e Jia } \\
(2010)\end{array}$ & $\begin{array}{l}\text { 1979, } 1990, \\
2000,2007\end{array}$ & $\begin{array}{l}\text { Tsup vs. ocupação } \\
\text { do solo }\end{array}$ & $\begin{array}{l}\text { Guangzhou } \\
\text { (China) }\end{array}$ & $\begin{array}{l}\text { Landsat MSS (1979), } \\
\text { TM (1990), ETM+ } \\
\text { (2000) e MODIS } \\
\text { (2007) + dados } \\
\text { microcimáticos e } \\
\text { dados do censo. }\end{array}$ & $\begin{array}{l}4 \text { cenas, uma para } \\
\text { cada ano }\end{array}$ & $\begin{array}{l}\text { A fração de cobertura verde apresentou correlação negativa com a } \mathrm{T}_{\text {sup. }} \text { Decréscimo de } 16,2 \% \text { na cobertura } \\
\text { arbórea correspondeu a um aumento de } 2,48 \% \text { na } \mathrm{T}_{\text {sup. Distribuição da }} \mathrm{T}_{\text {sup }} \text { é heterogenia e possui } \\
\text { correlação com a qtde de área construída e com as características sociais dos bairros. }\end{array}$ \\
\hline $\begin{array}{l}\text { Mildrexler et } \\
\text { al (2011) }\end{array}$ & $\begin{array}{l}2002-2006+ \\
2009\end{array}$ & $\begin{array}{l}\text { Tsup_max vs. } \\
\text { Tar_max }\end{array}$ & Global & $\begin{array}{l}\text { Aqua MODIS T } \\
(5 \mathrm{Km})+\text { estap̧ões } \\
\text { meteorológicas WMO } \\
\text { que possuem Tar_max }\end{array}$ & $\begin{array}{l}\text { Todas as cenas } \\
\text { (valores máximos } \\
\text { anuais) }\end{array}$ & $\begin{array}{l}\text { Correlação positiva entre } T_{\text {sup _max e Tar_max em todos os tipos de cobertura do solo. A correlação é }} \\
\text { dependente do tipo de solo e varia com a temperatura. Nas temperaturas mais altas as diferenças entre as } \\
\text { duas variáveis superam } 20 \text {. Nas temperaturas mais baixas as duas variáveis são bastante próximas para } \\
\text { todos os tipos de solo. As áreas florestais são as únicas que mantém relação próxima e estável entre as duas } \\
\text { variáveis mesmo em altas temperaturas por acessarem águas subterrâneas profundas mantendo a } \\
\text { evapotranspiração. Áreas florestais são importantes para o clima global, regional e local. T } T_{\text {sup }} \text { é mais sensivel } \\
\text { que a Tar às mudanças de densidade de vegetação. }\end{array}$ \\
\hline $\begin{array}{l}\text { Sousa e } \\
\text { Ferreira } \\
\text { (2012) }\end{array}$ & 2002 e 2011 & $\begin{array}{l}I C_{\text {sup }} \text { e anomalias } \\
\text { termais }\end{array}$ & $\begin{array}{l}\text { Goiânia } \\
\text { (Brasil) }\end{array}$ & Landsat TM e ETM+ & 2 cenas & $\begin{array}{l}\text { Tsup diurnas mais altas na área urbanizada, sendo as áreas verticalizadas mais amenas que as não } \\
\text { verticalizadas e temperaturas mais amenas nas áreas arborizadas. Não foi possível estabelecer tendência das } \\
\text { temperaturas apenas com } 2 \text { imagens. Recomendam abordagem temporal maior. }\end{array}$ \\
\hline
\end{tabular}




\begin{tabular}{|c|c|c|c|c|c|c|}
\hline $\begin{array}{l}\text { Zhou et al. } \\
\text { (2014) }\end{array}$ & $2003-2011$ & $\begin{array}{l}\text { IC } \mathrm{S}_{\text {sup }} \text { e fatores que } \\
\text { influenciam }\end{array}$ & $\begin{array}{l}32 \text { cidades na } \\
\text { China }\end{array}$ & Aqua MODIS & Todas as cenas & $\begin{array}{l}\text { IC } C_{\text {sup }} \text { mais intensa durante o dia no verão e durante a noite no inverno. IC } C_{\text {sup }} \text { diurna apresenta correlação } \\
\text { com EVI (verão), com o calor antropogênico e com a intensidade construtiva. No inverno, apresenta } \\
\text { correlação positiva com Tar e com a precipitação. IC sup noturna apresentou correlação com calor } \\
\text { antropogênico, com a intensidade construtiva, com a Tar, com a precipitação e com o albedo. Diferença } \\
\text { entre as } 32 \text { cidades é melhor explicada pelas diferenças de clima entre elas. Não foram encontradas } \\
\text { correlaçães significativas com o relevo nem com o tamanho das cidades. Confirmam importância da } \\
\text { vegetação para a IC } \mathrm{C}_{\text {sup diurna. }}\end{array}$ \\
\hline $\begin{array}{l}\text { Scarano e } \\
\text { Sobrino } \\
\text { (2015) }\end{array}$ & $\begin{array}{l}2013 \text { e } 2014 \\
\text { (dia) } 2001 \\
2003 \text { e } 2008 \\
\text { (noite) }\end{array}$ & $\begin{array}{l}T_{\text {sup vs. morfologia }} \\
\text { urbana }(F V C)\end{array}$ & Bari (Italia) & $\begin{array}{l}\text { Landsat ETM+ e TIRS + } \\
\text { Mapa 3D da cidade }\end{array}$ & $\begin{array}{l}4 \text { cenas diurnas e } 5 \\
\text { cenas noturnas }\end{array}$ & $\begin{array}{l}\text { Correlação positiva entre } \mathrm{T}_{\text {sup }} \text { e o FVC. Não foram encontradas interferências da sazonalidade nessa } \\
\text { correlação, porém os comportamentos diurnos e noturnos diferem. }\end{array}$ \\
\hline $\begin{array}{l}\text { Barros e } \\
\text { Lombardo } \\
(2016)\end{array}$ & 2011 & $\begin{array}{l}T_{\text {sup }} \text { vs. IAF vs. } \\
\text { ocupação do solo }\end{array}$ & São Paulo & Landsat TM & 1 cena diurna & $\begin{array}{l}\text { Autores identificaram a ausência de vegetação como sendo a principal causa da intensidade da } I C_{\text {sup }} \text {. } O \text { uso } \\
\text { predominante nas áreas de maior intensidade da } I C_{\text {sup }} \text { é o industrial, com grandes áreas impermeabilizadas. }\end{array}$ \\
\hline $\begin{array}{l}\text { Coutts et al. } \\
(2016)\end{array}$ & $\begin{array}{l}2012 \\
\text { (fevereiro, } \\
\text { durante } \\
\text { onda de } \\
\text { calor) }\end{array}$ & $\begin{array}{l}\text { Hotspots de Tar } \\
\text { via SR de alta } \\
\text { resolução }\end{array}$ & $\begin{array}{l}\text { Melbourne } \\
\text { (Australia) }\end{array}$ & $\begin{array}{l}\text { VHR }(0,5 \mathrm{~m}) \text { acoplado } \\
\text { em aeronave }\end{array}$ & $\begin{array}{l}1 \text { cena diurna e outra } \\
\text { notura de } 25 / \text { fev/2012 }\end{array}$ & $\begin{array}{l}\text { Altíssima resolução não correlacionou bem com Tar, melhor correlação foi encontrada com 30m de } \\
\text { resolução. Maior proporção de vegetação foi associada à menores valores de } T_{\text {sup }} \text { de dia e de noite. }\end{array}$ \\
\hline $\begin{array}{l}\text { Flores et al. } \\
\text { (2016) }\end{array}$ & 2001-2014 & $\begin{array}{l}\text { IC } \text { sup Vs. NDVI e } \\
\text { EVI }\end{array}$ & $\begin{array}{l}\text { São Paulo e } \\
\text { Rio de Janeiro } \\
\text { (Brasil) }\end{array}$ & $\begin{array}{l}\text { Aque e Terra MODIS } \\
\text { (reamostrado para } \\
5,6 \mathrm{~km} \text { ) }\end{array}$ & Todas as cenas & $\begin{array}{l}\text { A partir das médias mensais para todo o período analisado, verificaram: a sazonalidade da } I C_{\text {sup, }} \text { sua maior } \\
\text { intensidade em } \mathrm{SP} \text { e para o período diurno (Máxima diurna em Novembro, } 10,4^{\circ} \mathrm{C} \text {. Máxima noturna em } \\
\text { Setembro, com } 3,8^{\circ} \mathrm{C} \text { ). As áreas urbanas das duas cidades apresentaram correlação negativa com os IVs. }\end{array}$ \\
\hline $\begin{array}{l}\text { Sidiqui et al. } \\
\text { (2016) }\end{array}$ & $2003-2015$ & I $\mathrm{C}_{\text {sup }}$ & $\begin{array}{l}\text { Sydney } \\
\text { (Australia) }\end{array}$ & $\begin{array}{l}\text { Aqua e Terra MODIS } \\
\text { Landsat 8-TIRS }\end{array}$ & Todas as cenas & $\begin{array}{l}\text { IC } \mathrm{C}_{\text {sup }} \mathrm{S} \text { mais intensa durante o dia no verão. Não observaram tendência nos dados diurnos ou noturnos com } \\
\text { significância estatística. }\end{array}$ \\
\hline $\begin{array}{l}\text { Alexander et } \\
\text { al. (2017) }\end{array}$ & $2002-2014$ & $\begin{array}{l}\text { T sup vs. ocupação } \\
\text { do solo }\end{array}$ & $\begin{array}{l}\text { Dublin } \\
\text { (Irlanda) }\end{array}$ & $\begin{array}{l}\text { Terra MODIS + mapa } \\
\text { LCZ }\end{array}$ & Todas as cenas & $\begin{array}{l}50 \% \text { da variação da } T_{\text {sup }} \text { em Dublin pode ser explicada pela variação da fração de solo ocupado com } \\
\text { edificações ou com árvores. Aumentar a cobertura arbórea reduz a } T_{\text {sup }} \text {. Baseado no modelo de regressão } \\
\text { linear múltipla desenvolvido pelos autores com base na definição de um ano climatológico tipo para a } T_{\text {sup }} \text {, } \\
\text { prevê-se que aumentar a cobertura arbórea de } 10 \text { para } 40 \% \text { em uma área com } 33 \% \text { de solo ocupado por } \\
\text { edificações reduz a } T_{\text {sup }} \text { média anual em aproximadamente } 1,5 \mathrm{C} \text {. }\end{array}$ \\
\hline
\end{tabular}




\subsection{Técnicas para observação da vegetação urbana}

As técnicas de observação da vegetação, assim como as de observação da temperatura de superfície, também se relacionam diretamente com a escala da análise, podendo centrarse em análises de uma única folha, ou conjunto de folhas, e análises de áreas vegetadas ou dosséis. Trabalhos que, como este, se propõem a analisar o papel da vegetação no clima (urbano ou não) trabalham com análises focadas em áreas e dosséis vegetais.

A influência da vegetação no clima é frequentemente abordada por meio de modelos numéricos. A escala desses modelos e sua resolução espacial são limitadas a recursos computacionais (LI et al., 2015). Assim, estudos de grande escala espacial muitas vezes apresentam pouco detalhamento dos fenômenos na escala local. Já modelos mais detalhados centram-se em fenômenos microclimáticos como, por exemplo, a influência de um parque ou de um conjunto de árvores em seu entorno imediato. Dessa forma estudos sobre a influência da vegetação em bairros ou cidade apoiam-se com mais frequência em técnicas observacionais.

Em estudos que utilizam técnicas observacionais de análise da vegetação no clima local o uso do SR como ferramenta é bastante recorrente. Historicamente, porém, o uso de SR para estudos da vegetação é mais frequente em trabalhos sobre a distribuição da vegetação em áreas florestais ou agrícolas, estudos sobre o ciclo fenológico, alterações fisiológicas em áreas agrícolas, desmatamento de áreas florestais etc. O uso do SR para estudos de vegetação intra-urbana é mais recente e ainda menos frequente que os estudos rurais e florestais.

\subsubsection{Características espectrais da vegetação}

O comportamento espectral da vegetação é distinto do comportamento dos demais materiais que compõem o ambiente urbano (Figura 16). A vegetação apresenta baixa refletância da REM na região do vermelho, porém alta na região do infravermelho (IV) próximo, enquanto materiais como concreto, asfalto, telhas etc. refletem altas parcelas da REM na região do verde, vermelho e infravermelho próximo (JENSEN, 2009). 
A Figura 17 apresenta o comportamento espectral típico para uma folha verde saudável. Os pigmentos presentes na vegetação verde sadia (especialmente as clorofilas) absorvem a REM na região do visível (principalmente nas regiões do azul e do vermelho) de forma eficaz, uma vez que estas regiões espectrais são necessárias para a fotossíntese. Na região do IV próximo, porém, a estrutura interna das folhas determina grande parte do espalhamento e da reflexão nesse comprimento de onda, que se absorvido pela vegetação provocaria aquecimento danificando suas proteínas. Já na região do IV médio, o conteúdo de água foliar determina a absorção da REM de forma que quanto maior a presença de água na folha, maior será a absorção nessa região do espectro (JENSEN, 2009; PONZONI; SHIMABUKURO; KUPLICH, 2012).
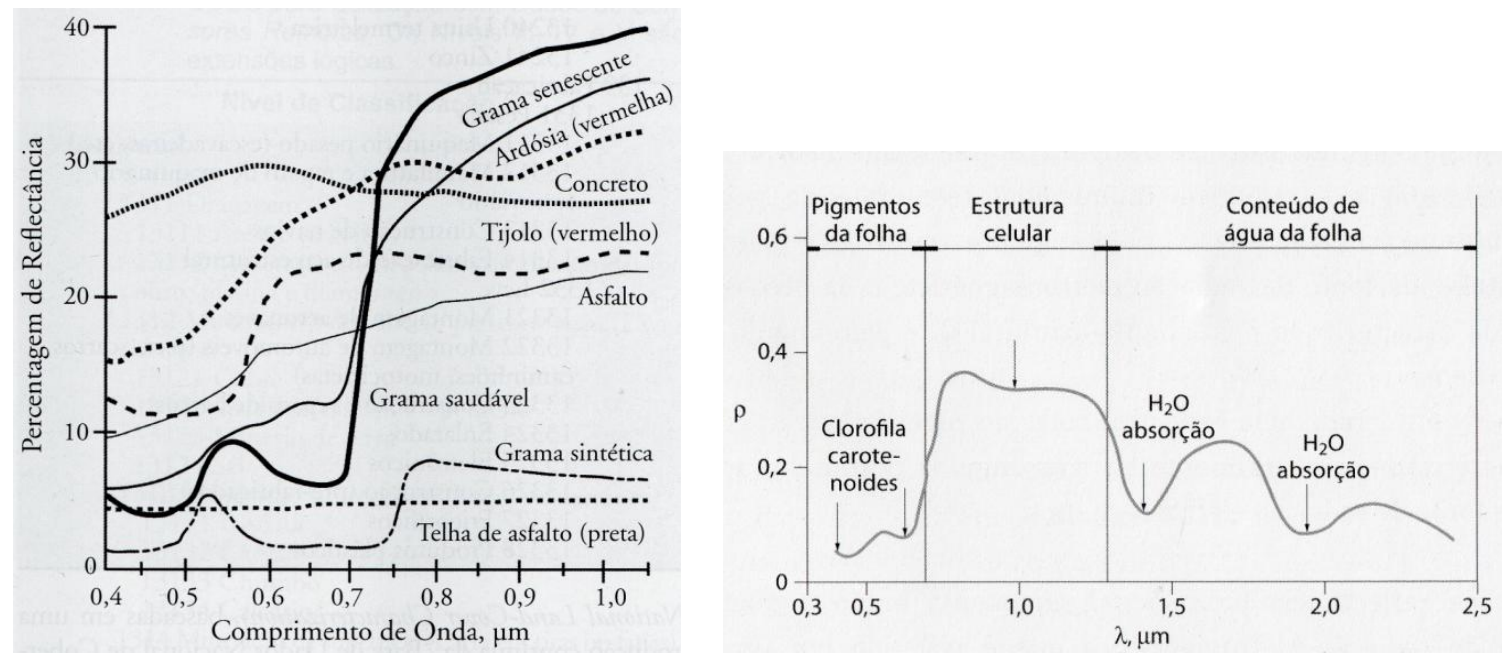

Figura 16. Percentual de refletância de diferentes Figura 17. Curva espectral típica de uma folha verde. Fonte: materiais urbanos medidas em laboratório. Fonte: Novo (1989) ${ }^{21}$ apud Ponzoni; Shimabukuro; Kuplich, (2012). Jensen, 2009.

As quantidades de REM absorvidas e refletidas nas regiões do visível e do IV próximo podem variar de acordo com fatores ambientais e patogênicos que interfiram na composição química ou estrutural das folhas. A Figura 18 e a Figura 19 mostram o comportamento de folhas de uma mesma planta, porém em estágios de senescência diferentes (Figura 18) e com umidades distintas (Figura 19). O estudo de faixas específicas do espectro eletromagnético permite verificar tais características.

${ }^{21}$ Novo, E. M. L. M. Sensoriamento Remoto: princípios e aplicações. São Paulo: Blüncher, 1989. 


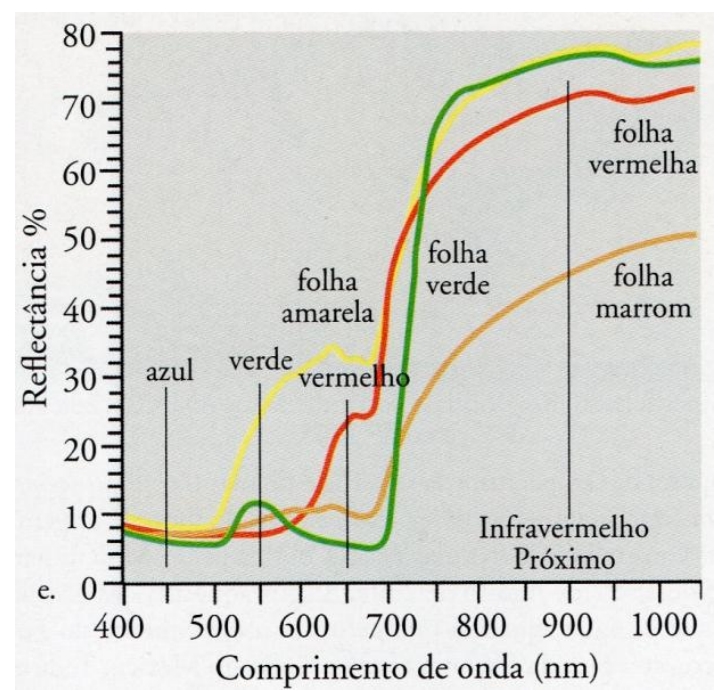

Figura 18. Refletância espectral de quatro folhas diferentes obtidas de uma mesma árvore sadia (Liquidambar styraciflua L). Fonte: Jensen, 2009.

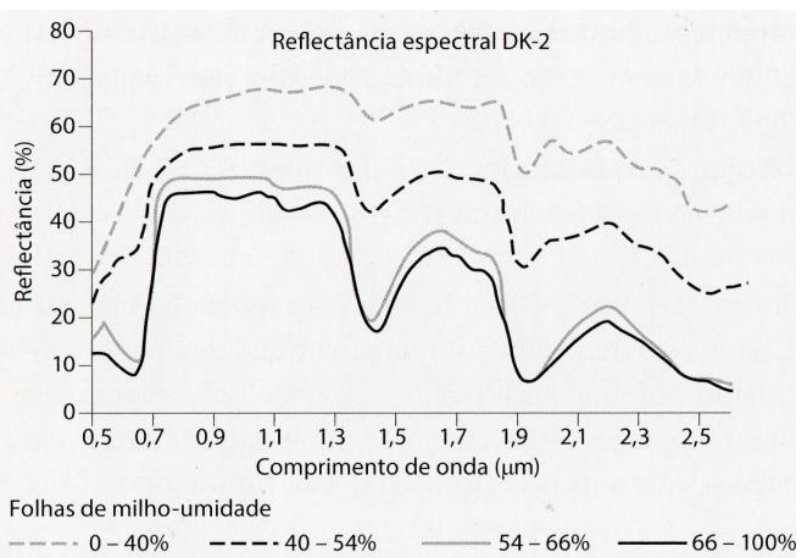

Figura 19. Influência da umidade na refletância espectral de uma folha de milho. Fonte: Kumar $(1974)^{22}$ apud Ponzoni; Shimabukuro; Kuplich, (2012).

De acordo com Ponzoni; Shimabukuro e Kuplich, (2012), dosséis vegetais apresentam comportamento semelhante ao descrito para as folhas, porém com efeito de absorção e espalhamento aditivos proporcionado pelas várias camadas de folha que formam um dossel. Considerando-se um dossel hipotético, formado apenas por folhas dispostas horizontalmente umas sobre as outras e considerando que a vegetação não é totalmente opaca à REM, espera-se que a adição de folhas aumente a quantidade de pigmentos que absorvem a REM na região do visível e aumente também a quantidade de REM refletida na região do IV próximo, conforme esquema da Figura 20. Assim, quanto mais camadas um dossel possuir, maior será a absorção esperada na região do visível e maior a reflexão esperada na região do IV próximo. Contudo, esse comportamento não é linear, apresentando pontos de saturação distintos, como mostra a Figura 21.

Dosséis reais, no entanto, apresentam outras características que interferem na resposta radiométrica. A arquitetura do dossel, a angulação das folhas e a quantidade de REM refletida pelo solo abaixo do dossel, são fatores que interferem na quantidade de REM refletida (PONZONI; SHIMABUKURO; KUPLICH, 2012). Apesar das interferências e limitações mencionadas, as respostas do IV e do vermelho são indicativos significativos sobre a quantidade de biomassa de um dossel (JENSEN, 2009).

\footnotetext{
${ }^{22}$ KUMAR, R. Radiation from plants-reflection and emission: a review. Purdue Research Foundation, 1974.
} 


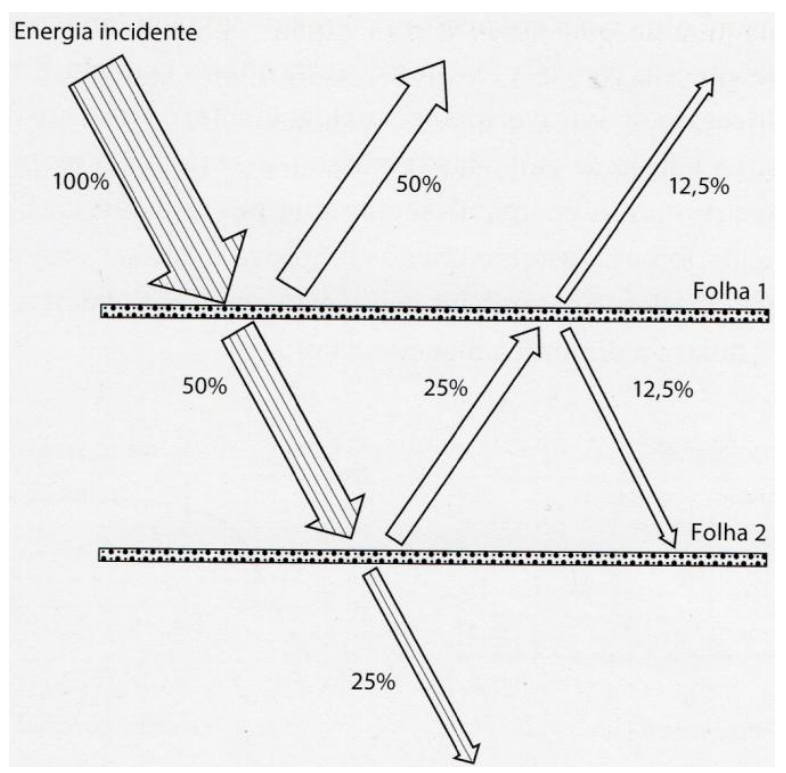

Figura 20. Reflexão múltipla da REM no IV próximo em dossel hipotético.
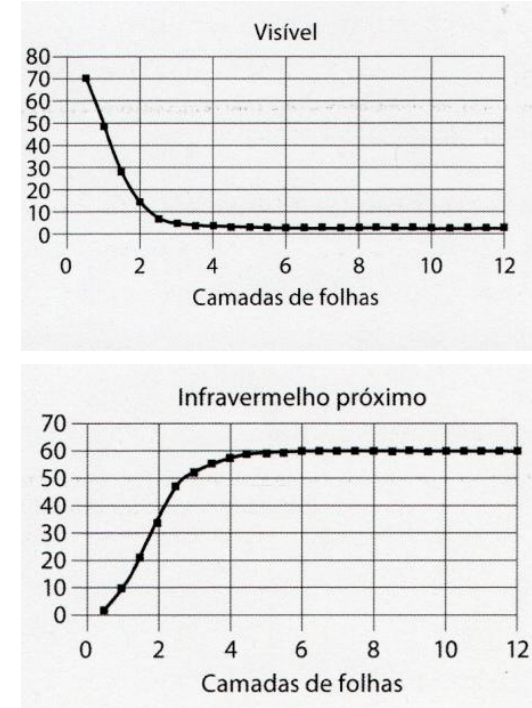

Figura 21. Fatores de refletância em dosséis hipotéticos vs. camadas de folhas.

Fonte: Ponzoni; Shimabukuro; Kuplich, (2012).

A relação entre as refletâncias do vermelho e do IV próximo para diferentes áreas de uma zona agrícola pode ser vista na Figura 22a. A Figura 22b apresenta a mesma relação para um pixel também agrícola, porém em várias fases do ciclo fenológico.

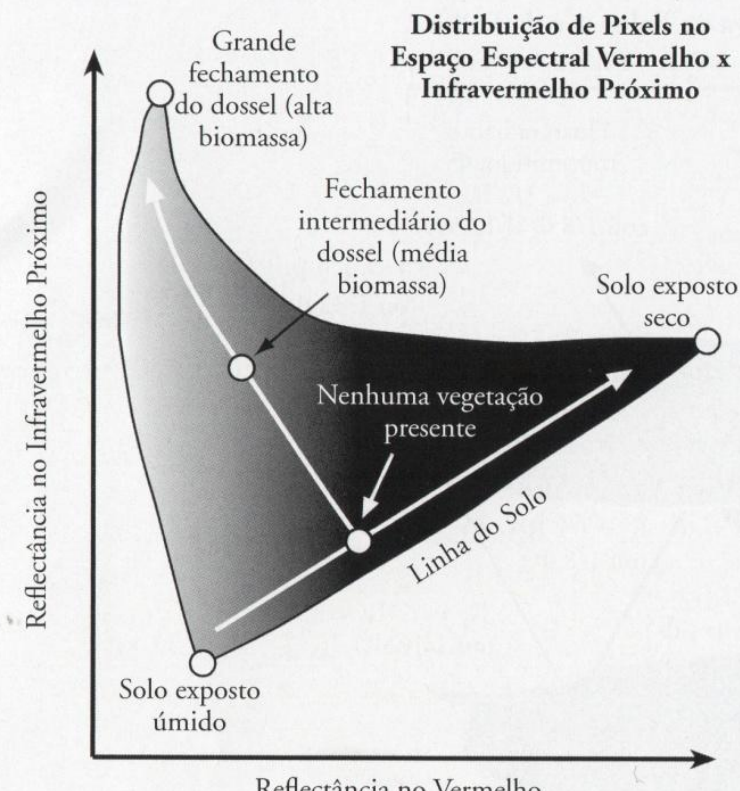

Reflectância no Vermelho

a.

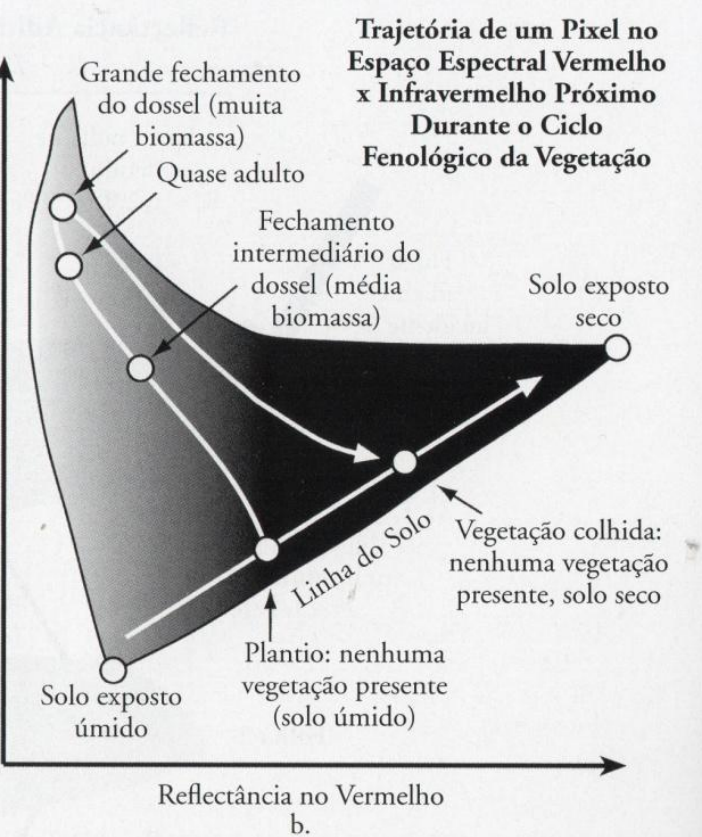

Figura 22. Relação entre a refletância do IV próximo e do vermelho para (a) diferentes áreas de uma zona agrícola e (b) para diferentes fases do ciclo fenológico. Fonte: Jensen, 2009. 
Nessas imagens é possível verificar que quanto maior a quantidade de biomassa maior a refletância no IV próximo e menor no vermelho. Para quantidades menores de biomassa, a refletância no IV próximo diminui e, no vermelho, aumenta.

\subsection{2 Índices de vegetação}

Baseado no comportamento espectral da vegetação nessas duas faixas do espectro eletromagnético diversos índices de vegetação (IVs) foram desenvolvidos com o objetivo de avaliar qualitativa e quantitativamente a cobertura vegetal, indicando a abundância relativa e a atividade fotossintética da vegetação verde, ao mesmo tempo em que minimizam os efeitos de iluminação, declividade, geometria etc. (JENSEN, 2009; PONZONI; SHIMABUKURO; KUPLICH, 2012). Tais índices são transformações espectrais de duas ou mais bandas que buscam ressaltar as propriedades da vegetação, permitindo comparações espaciais e temporais (HUETE et al., 2002a).

Existem diversos IVs e uma analise comparativa entre eles pode ser encontrada em Silleos et al. (2006) e Jensen (2009). Neste trabalho foram utilizados os dois índices de vegetação produzidos pelo Moderate Resolution Imaging Spectroradiometer (MODIS), a bordo do satélite Aqua: o Índice de Vegetação por Diferença Normalizada (Normalized Difference Vegetation Index- NDVI) e o Índice de Vegetação Realçado (Enhanced Vegetation Index $\mathrm{EVI})$.

O NDVI foi desenvolvido por Rouse et al. em 1974 com o objetivo de separar a vegetação do brilho do solo usando dados do Landsat MSS (SILLEOS et al., 2006). Sua aplicação permite monitorar alterações sazonais e interanuais no desenvolvimento e atividade da vegetação, reduzindo diferenças de incidência da radiação solar, sombras de nuvens e variações topográficas (HUETE et al., 2002a; JENSEN, 2009). Apesar da ampla utilização do

NDVI por pesquisadores das mais diversas áreas, a interpretação desse índice deve considerar, segundo Ponzoni, Shimabukuro e Kuplich (2012) e Jensen (2009), as seguintes limitações: a) o NDVI é altamente correlacionado com a densidade da vegetação; porém, para determinadas densidades pode ocorrer uma saturação do NDVI, alterando o comportamento esperado deste índice; b) o NDVI apresenta sensibilidade às variações de substrato do dossel. Com substratos mais escuros, o NDVI pode ser mais alto, assim, 
alterações de pavimento sob o dossel podem provocar alterações no NDVI sem que a quantidade de biomassa tenha sido alterada.

O NDVI é definido pela seguinte equação:

$$
N D V I=\frac{\rho_{N I R}-\rho_{R E D}}{\rho_{N I R}+\rho_{R E D}}
$$

(Equação 2)

Onde: $\rho_{N I R}$ é o fluxo radiante no IV próximo e $\rho_{R E D}$ o fluxo radiante no vermelho.

O NDVI pode variar de -1 a 1 . Valores negativos são atribuídos a superfícies não vegetadas, como corpos d'água, valores próximos de 1 a áreas com grandes quantidades de biomassa e valores próximos a zero a áreas sem vegetação (SILLEOS et al., 2006). Para Sau et al. (2016) valores abaixo de 0,2 geralmente correspondem a áreas não vegetadas e, valores acima de 0,3 , a superfícies com cobertura vegetal.

O Índice de Vegetação Realçado (EVI) foi desenvolvido pelo MODIS Land Discipline Group para ser usado com dados deste sensor ${ }^{23}$ com o objetivo de melhorar a sensibilidade em regiões de alta biomassa por meio do desacoplamento do sinal de fundo do dossel e uma redução nas influências atmosféricas (HUETE et al., 2002a), sendo definido pela seguinte equação:

$$
E V I=G \frac{\rho_{N I R}-\rho_{R E D}}{\rho_{N I R}+C_{1} * \rho_{R E D}-C_{2} * \rho_{B L U E}+L}(1+L) \quad \text { (Equação 3) }
$$

Onde $L$ é o fator de ajuste para o solo, $C_{1}$ e $C_{2}$ são coeficientes determinados empiricamente que descrevem o uso da banda azul para correção do espalhamento atmosférico da banda vermelha por aerossóis e $G$ é um fator de escala. Os valores

\footnotetext{
${ }^{23}$ O sensor MODIS (Moderate Resolution Imaging Spectroradiometer) encontra-se a bordo dos satélites Terra e Aqua. Juntos estes satélites produzem quatro imagens diárias, ou a cada dois dias, de todo o planeta. As passagens do Terra ocorrem às $10 \mathrm{~h} 30$ e às $22 \mathrm{~h} 30$ e as do Aqua às $13 \mathrm{~h} 30$ e $1 \mathrm{~h} 30$ LST - Local Standard Time.
} 
empiricamente determinados para os coeficientes são: $L=1, C_{1}=6, C_{2}=7,5$ e $G=2,5$ (DIDAN; MUNOZ; HUETE, 2015).

Os fatores de ajuste presentes no EVI fazem com que este apresente valores sempre menores que o NDVI, evitando a saturação em áreas de grande quantidade de biomassa. Porém, a variação sazonal entre as estações secas e chuvosas para os dois índices é semelhante (HUETE et al., 2002a).

Em levantamento realizado com os doze primeiros meses dos IVs gerados pelo TerraMODIS em quatro biomas diferentes, Huete et al. (2002a) verificaram que os dois índices apresentaram boa sensibilidade para variações sazonais e biofísicas da vegetação. Os valores medidos de NDVI variaram de 0,05 a 0,9, enquanto os valores de EVI variaram de 0,05 a 0,65, evidenciando a habilidade deste último de não saturação em áreas de grande biomassa, como a Floresta Nacional do Tapajós, no Pará.

\subsubsection{Aplicações do sensoriamento remoto da vegetação com ênfase em análises climáticas}

Diversas são as possibilidades de aplicação do SR para estudos das relações entre vegetação e clima. Existem estudos que abordam variáveis específicas de árvores isoladas, como a temperatura da copa (LEUZINGER; VOGT; KÖRNER, 2010), estudos que trabalham com a relação entre a vegetação urbana e a $T_{\text {sup }}$ para cidades e regiões específicas (ACERO; GONZÁLEZ-ASENSIO, 2018; ADAMS; SMITH, 2014; ALAVIPANAH et al., 2015; HANG; RAHMAN, 2018; JENERETTE et al., 2007; WENG; LU; SCHUBRING, 2004) e análises de tendência global para diferentes índices de vegetação e para variáveis climáticas, como $T_{\text {sup, }} T_{\text {ar }}$ ou precipitação (ECKERT et al., 2015; SOBRINO; JULIEN, 2013).

De maneira geral, os resultados das pesquisas que buscam relacionar a vegetação urbana, indicada pela abundância de vegetação e descrita por diferentes IVs, com a $T_{\text {sup }}$ indicam a existência de uma correlação negativa entre as duas grandezas. Acero e González-Asensio (2018) e Hang e Rahman (2018) verificaram forte correlação negativa entre a $T_{\text {sup }}$ e o NDVI respectivamente em San Salvador e na região de Nova Deli (Índia), similar aos resultados de Weng, Lu e Schubring (2004) para a cidade de Indianápolis usando o NDVI e a fração de vegetação verde. Resultados semelhantes também foram verificados por Adams e Smith 
(2014) para Sydney, onde tanto a presença de vegetação quanto a distância da costa influenciam a $\mathrm{T}_{\text {sup. }}$. Para o levantamento realizado entre 2000 e 2011 os autores verificaram que a vegetação arbórea possui maior influência na $T_{\text {sup }}$ do que a vegetação não arbórea. Em Phoenix, Jenerette et al. (2007) constataram, além da forte correlação negativa entre a $T_{\text {sup }}$ e o índice de vegetação SAVI (Soil Adjusted Vegetation Index), a influência de padrões socioeconômicos, como a renda média do responsável pelo domicílio e a porcentagem de população hispânica. Os autores concluiram que a condição sócio econômica influencia a quantidade e qualidade da vegetação, que por sua vez influencia a $T_{\text {sup }}$. Entre os setores censitários de menor renda e os de maior renda foi observada uma diferença de $\mathrm{T}_{\text {sup }}$ de $1,4^{\circ} \mathrm{C}$. Em Munique (Alemanha), Alavipanah et al. (2015) verificaram que a relação entre a vegetação e a $T_{\text {sup }}$ não é linear, sendo os efeitos do resfriamento mais pronunciados quando a cobertura encontra-se entre 70 e $80 \%$. Tais resultados diferem dos anteriormente apresentados, uma vez que não atribuem a menor

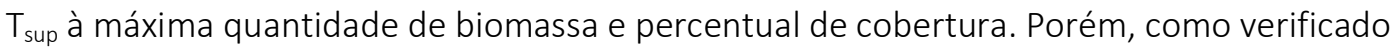
por Leuzinger, Vogt e Körner (2010) a $\mathrm{T}_{\text {sup }}$ do topo da copa (área lida pelo SR) depende da espécie e da localização da árvore. Além disso, uma área parcialmente coberta por vegetação apresentaria uma resposta termal composta pela temperatura do dossel e do solo exposto entre o dossel (WENG; LU; SCHUBRING, 2004). Caso o solo exposto apresente-se úmido e sombreado, este poderia apresentar $T_{\text {sup }}$ menor que a da copa das árvores, fazendo com que um pixel parcialmente coberto por vegetação apresentasse $T_{\text {sup }}$ menor que um pixel totalmente coberto. Outros estudos seriam necessários para corroborar a não linearidade entre $T_{\text {sup }}$ e o percentual de cobertura arbórea.

O uso de índices de vegetação combinados com informações sobre $T_{\text {sup }}$ adquiridas por SR é considerado uma importante ferramenta para o planejamento urbano e regional (HANG; RAHMAN, 2018) e para o planejamento e projeto da vegetação urbana como estratégia de mitigação dos efeitos da ilha de calor, especialmente em áreas tropicais (ACERO; GONZÁLEZ-ASENSIO, 2018).

Os estudos que utilizam análises de tendência empregam séries temporais elaboradas a partir de dados de SR de alta resolução temporal, como os produzidos pelo MODIS (com dados diários). Dada a ausência de dados decorrente da presença de nuvens, as séries temporais comumente são reconstruídas, por meio do preenchimento dos dados 66 
faltantes com valores de pixels vizinhos ou com valores médios de toda a série para o pixel faltante. O exame de séries temporais emprega análises estatísticas sofisticadas.

Em estudo global realizado por Sobrino e Julien (2013) foi verificado aumento da $T_{\text {sup }}$ mínima em todos os continentes, sendo o aumento verificado no sul da região amazônica atribuido ao desmatamento. Fato semelhante foi verificado por Esau et al. (2016) em estudo para 28 cidades na Sibéria, atribuindo as diminuições mais drásticas do NDVI ao desmatamento decorrente do avanço da ocupação urbana. Aumentos do NDVI em áreas urbanas também foram verificados, o que, segundo os autores, pode ser atribuído tanto às políticas de arborização urbana quanto às mudanças climáticas que, ao aumentarem as temperaturas, proporcionam maior desenvolvimento da vegetação nessa área. Eckert et al. (2015) analisaram 11 anos de dados Terra-MODIS NDVI para a Mongolia e constataram que as áreas com alteração de cobertura do solo corresponderam às áreas com alteração de NDVI.

A Tabela 3 sintetiza as principais características e conclusões dos estudos sobre a aplicação do SR da vegetação, principalmente em estudos de clima, levantados pelo presente trabalho. 
Tabela 3. Síntese dos estudos com aplicação do SR da vegetação com ênfase em pesquisas sobre clima.

\begin{tabular}{|c|c|c|c|c|c|c|}
\hline $\begin{array}{l}\text { Autores } \\
\text { (ano) }\end{array}$ & $\begin{array}{l}\text { Período } \\
\text { analisado }\end{array}$ & Objeto de estudo & $\begin{array}{l}\text { Local } \\
\text { estudo }\end{array}$ & Dados utilizados & $\begin{array}{l}\text { Qtde de cenas } \\
\text { orbitais usadas }\end{array}$ & Principais conclusões \\
\hline $\begin{array}{l}\text { Huete et al. } \\
\text { (2002a) }\end{array}$ & 2000 & NDVI e EVI & $\begin{array}{l}4 \quad \text { biomas } \\
\text { diferentes }\end{array}$ & $\begin{array}{l}\text { Terra MODIS vs. Landsat } \\
\text { ETM+ / NOAA-14 AVHRR / } \\
\text { medidas radiométricas de } \\
\text { avião e medidas de solo }\end{array}$ & $\begin{array}{l}\text { Todas as cenas } \\
\text { com boa } \\
\text { qualidade }\end{array}$ & $\begin{array}{l}\text { Todas as medidas mostraram boa correspondência com os IVs do MODIS. Resultados MODIS mostraram-se } \\
\text { mais sensíveis e precisos que os do NOAA. Os dois índices mostraram-se capazes de captar alterações } \\
\text { sazonais e espaciais em diferentes biomas. NDVI apresenta saturação em biomas com grande quantidade de } \\
\text { biomassa, enquanto o EVI mostrou-se mais sensível nessas regiões. }\end{array}$ \\
\hline $\begin{array}{l}\text { Weng et al. } \\
\text { (2004) }\end{array}$ & 2002 & $\mathrm{~T}_{\text {sup }}$ vs. FVV e NDVI & $\begin{array}{l}\text { Indianápolis } \\
\text { (EUA) }\end{array}$ & Landsat ETM+ & 1 & $\begin{array}{l}\text { Comparam a } T_{\text {sup }} \text { com } 2 \text { indicadores da abundância da vegetação: NDVI e Fração de Vegetação Verde (FVV) } \\
\text { Ambos mostraram forte correlação negativa com a } T_{\text {sup, }} \text { portanto quanto maior a abundância de vegetação } \\
\text { em uma área, menor sua temperatura (correlação com FVV é ligeiramente maior que com o NDVI). }\end{array}$ \\
\hline $\begin{array}{l}\text { Jenerette et } \\
\text { al. (2007) }\end{array}$ & 2000 & $\begin{array}{l}\mathrm{T}_{\text {sup }} \text { vs. SAVI vs. } \\
\text { dados do Censo }\end{array}$ & Phoenix (EUA) & Landsat ETM+ & 1 & $\begin{array}{l}\text { A } T_{\text {sup }} \text { apresentou correlação negativa com o SAVI, correlação positiva com a renda média do responsável e } \\
\text { correlação negativa com a porcentagem de população hispânica. A condição socioeconômica influencia a } \\
\text { quantidade e a qualidade da vegetação, que influencia a } T_{\text {sup. }} \text {. Bairros mais pobres apresentaram } T_{\text {sup }} 1,4 C \\
\text { acima dos bairros mais ricos. Espera-se maior impacto a noite. }\end{array}$ \\
\hline $\begin{array}{l}\text { Leuzinger et } \\
\text { al. (2010) }\end{array}$ & 2004 & $\begin{array}{l}T_{\text {sup }} \text { copa e folha } \\
\text { vs. Tar }\end{array}$ & Basel (Suíça) & $\begin{array}{l}\text { Câmera termal de alta } \\
\text { resolução }(0,7 \mathrm{~m})\end{array}$ & 1 & $\begin{array}{l}\text { Temperatura da copa depende da espécie, da localização da árvore, do tamanho da folha e da condutividade } \\
\text { estomatal. Árvores de rua apresentam temperatura } 1 \mathrm{~K} \text { mais alta que as de parques (por conta da maior } \\
\text { incidência de radiação de onda curta e longa refletida e emitida pelas superfícies do entorno). Árvores de } \\
\text { folhas pequenas tem menor temperatura que as de folha grande. Em condições extremas (tar>40C) } \\
\text { temperatura da folha de algumas espécies aumenta exponencialmente e podem ficar } 10 \mathrm{~K} \text { acima da } \\
\text { temperatura ambiente. Espécies de folha pequena permanecem menos aquecidas nessas condições. }\end{array}$ \\
\hline $\begin{array}{l}\text { Sobrino e } \\
\text { Julien (2013) }\end{array}$ & $2000-2011$ & $\begin{array}{lr}\text { Análise } & \text { de } \\
\text { tendência } & \text { NDVI, } \\
\text { EVI e } T_{\text {sup }}\end{array}$ & Global & $\begin{array}{l}\text { Terra MODIS Tsup e IVs } \\
\text { (mensal) }\end{array}$ & $\begin{array}{l}\text { Série temporal } \\
\text { completa } \\
\text { (reconstruída) }\end{array}$ & $\begin{array}{l}\text { Aumento acentuado da } T_{\text {sup }} \text { mínima em todos os continentes, especialmente nas áreas boreais. Aumento da } \\
T_{\text {sup }} \text { no sul da Amazônia pode ser atribuído ao desmatamento, verificado por alterações em parâmetros do } \\
\text { YLCD (yearly land cover dynamics): aumento do angulo da reta de regressão ( } T_{\text {sup }} \text { vs.IVs) maior amplitude } \\
\text { sazonal, etc. }\end{array}$ \\
\hline $\begin{array}{l}\text { Adams e } \\
\text { Smith (2014) }\end{array}$ & $\begin{array}{l}\text { 2000-2011 } \\
\text { (Dez-Fev) }\end{array}$ & $\begin{array}{l}T_{\text {sup }} \text { vs. CVM vs. } \\
\text { CAb }\end{array}$ & $\begin{array}{l}\text { Sydney } \\
\text { (Austrália) }\end{array}$ & $\begin{array}{l}\text { Terra MODIS } \mathrm{T}_{\text {sup }}+\mathrm{DEM}+ \\
\text { FPAR MODIS + outros } \\
\text { índices }\end{array}$ & $\begin{array}{l}\text { Todas as cenas } \\
\text { (imagem média } \\
\text { do período) }\end{array}$ & $\begin{array}{l}\text { Compara a relação entre } T_{\text {sup }} \text { (ajustada para a elevação) e cobertura de vegetação mista (CVM) e cobertura } \\
\text { arbórea (CAb). A } T_{\text {sup }} \text { é influenciada pela presença de vegetação e distância da costa. O aumento da } \\
\text { densidade de cobertura vegetal diminui a } T_{\text {sup }} \text {. A vegetação arbórea tem maior influência na } T_{\text {sup }} \text { do que a a } a \text { aspecto nas } T_{\text {sup. (relação é quadrática) }}\end{array}$ \\
\hline $\begin{array}{l}\text { Alavipanah } \\
\text { et al. (2015) }\end{array}$ & $\begin{array}{l}\text { 2002-2012 } \\
\text { (Junho, Julho, } \\
\text { Agosto) }\end{array}$ & $\begin{array}{l}\text { Superfície } \\
\text { impermeável vs. } \\
\text { vegetação vs. } T_{\text {sup }}\end{array}$ & $\begin{array}{l}\text { Munique } \\
\text { (Alemanha) }\end{array}$ & $\begin{array}{l}\text { Aqua MODIS } T_{\text {sup }} \text { (média } \\
\text { mensal) }+ \text { Corine Land } \\
\text { Cover }(2 \text { classes })\end{array}$ & $\begin{array}{l}\text { Todas as cenas } \\
\text { (média anual) }\end{array}$ & $\begin{array}{l}T_{\text {sup }} \text { mais altas em áreas nas áreas urbanas densamente ocupadas. } 2003 \text { foi o ano mais quente e } 2005 \text { o ano } \\
\text { mais frio. Efeito de resfriamento da vegetação não é linear, sendo mais pronunciado quando cobertura está } \\
\text { entre } 70 \text { e } 80 \% \text {. }\end{array}$ \\
\hline $\begin{array}{l}\text { Eckert et al. } \\
(2015)\end{array}$ & 2001-2011 & $\begin{array}{l}\text { Análise de } \\
\text { tendência NDVI vs. } \\
\text { precipitação e Tar }\end{array}$ & Mongólia & $\begin{array}{l}\text { Terra MODIS land cover + } \\
\text { IVS + dados climáticos }\end{array}$ & $\begin{array}{l}\text { Série temporal } \\
\text { completa } \\
\text { (reconstruída) }\end{array}$ & $\begin{array}{l}\text { O produto MODIS de cobertura do solo mostrou-se adequado para identificação de alterações na cobertura } \\
\text { vegetal. As áreas com alteração de cobertura do solo correspondem às áreas com alteração de NDVI. } \\
\text { Alterações na precipitação podem ter influenciado as alterações de NDVI, já que há coincidência entre as } \\
\text { tendências. Não foram observadas tendências na Tar. A análise de pontos de controle mostrou que a } \\
\text { adequação das } T_{\text {sup }} \text { do MODIS NDVI para detectar áreas de mudança de vegetação em grande e pequena } \\
\text { escala. }\end{array}$ \\
\hline
\end{tabular}




\begin{tabular}{|c|c|c|c|c|c|c|}
\hline $\begin{array}{l}\text { Esau et al. } \\
\text { (2016) }\end{array}$ & $\begin{array}{l}2000- \\
2014\end{array}$ & $\begin{array}{l}\text { Análise de } \\
\text { tendência } \\
\text { NDVI_max }\end{array}$ & $\begin{array}{l}28 \text { cidades na } \\
\text { Sibéria } \\
\text { (Rússia) }\end{array}$ & $\begin{array}{l}\text { Terra MODIS (Junho, } \\
\text { Julho e Agosto) }\end{array}$ & $\begin{array}{l}\text { Todas as } \\
\text { cenas } \\
\text { (máximos do } \\
\text { verão) }\end{array}$ & $\begin{array}{l}\text { Áreas ao norte apresentaram aumento de NDVI e áreas ao sul apresentaram diminuição do NDVI. As diminuições mais } \\
\text { drásticas foram verificadas em áreas de desenvolvimento urbano. Várias cidades apresentaram aumento de NDVI em } \\
\text { sua área urbana, o que pode ser explicado tanto por aumento das políticas de arborização, como pelas mudanças } \\
\text { climáticas que aumentam as temperaturas e proporcionam o aumento de produtividade de gramíneas e arbustos. }\end{array}$ \\
\hline $\begin{array}{l}\text { Acero e } \\
\text { González- } \\
\text { Asensio (2018) }\end{array}$ & $\begin{array}{l}2000 \text { e } \\
2015\end{array}$ & $\begin{array}{l}\mathrm{T}_{\text {sup }} \text { e NDVI } \\
\text { (anomalias) }\end{array}$ & $\begin{array}{l}\text { Região } \\
\text { Metropolitana } \\
\text { de San } \\
\text { Salvador (El } \\
\text { Salvador) }\end{array}$ & Landsat TM e TIRS & $\begin{array}{l}16 \text { cenas (4 } \\
\text { por estação } \\
\text { seca e } \\
\text { chuvosa por } \\
\text { ano) }\end{array}$ & $\begin{array}{l}\text { Forte correlação entre valores médios de NDVI por bairro e } T_{\text {sup. }} \text {. } \\
\text { Áreas com as maiores anomalias positivas de } T_{\text {sup }} \text { correspondem às áreas mais urbanizadas e áreas com maiores } \\
\text { anomalias negativas de } T_{\text {sup }} \text { correspondem àquelas com maior presença de vegetação. Alterações na } T_{\text {sup }} \text { entre } 2000 \text { e } \\
2015 \text { podem ser atribuídas à substituição da vegetação arbórea densa por processos de urbanização (Aumento de } 0,5^{\circ} \mathrm{C} \\
\text { na anomalia de } T_{\text {sup }} \text { ). } \\
\text { Altitude também influenciou a } T_{\text {sup }} \text { em alguns bairros. }\end{array}$ \\
\hline $\begin{array}{l}\text { Hang e } \\
\text { Rahman } \\
\text { (2018) }\end{array}$ & 2014 & $\begin{array}{l}T_{\text {sup }} \text { Vs. NDVI vs. } \\
\text { uso e ocupação } \\
\text { do solo }\end{array}$ & $\begin{array}{l}\text { National } \\
\text { Capital } \\
\text { Region, Índia }\end{array}$ & Landsat TIRS & 1 cena (Maio) & $\begin{array}{l}\text { As maiores } T_{\text {sup }} \text { foram observadas sem áreas de solo exposto, seguidas por áreas densamente urbanizadas. Áreas } \\
\text { urbanizadas sem planejamento apresentam } T_{\text {sup }} \text { bastante elevadas. Forte correlação linear negativa entre } T_{\text {sup }} \text { e NDVI. O } \\
\text { SR pode ser usado de forma eficaz para a análise do comportamento térmico de diferentes classes de uso e ocupação do } \\
\text { solo, fornecendo subsídios para o planejamento urbano, juntamente com os importantes efeitos da vegetação na } \\
\text { diminuição das } T_{\text {sup }}\end{array}$ \\
\hline
\end{tabular}




\subsection{Técnicas para descrição da morfologia urbana}

As características do tecido urbano são de interesse recorrente em trabalhos da Arquitetura e Urbanismo, sendo comumente estudados por meio de classificações de uso e ocupação do solo (UOS). Porém, a utilização desse tipo de classificação em estudos de clima urbano apresenta limitações. As classes tradicionalmente usadas nos mapas de UOS, apesar de apresentarem boa correspondência com a $T_{\text {sup }}$ (WENG, 2001), não apresentam detalhamento das propriedades das superfícies (STEWART; OKE, 2012), sendo que a maioria das classificações apresenta poucas classes para descrever as áreas urbanas, e não raro apresentam apenas uma classe.

Em estudos de clima urbano, sobretudo nos que visam subsidiar decisões em planejamento, é importante diferenciar a resposta climática das diferentes estruturas urbanas (por exemplo, prédios altos versus prédios baixos, formas compactas versus formas esparsas, cobertura verde densa versus cobertura verde esparsa) para considerálas nos planos e regulamentos urbanos (WICKI; PARLOW, 2017).

A classificação proposta por Stewart e Oke (2012) denominada Local Climate Zones (LCZ), objetiva detalhar as respostas climáticas de diferentes estruturas urbanas e extrair a magnitude da ilha de calor pela diferença entre essas estruturas, e não apenas pela diferença entre áreas urbanas e rurais.

As LCZs são definidas como regiões com cobertura uniforme do solo, estrutura, materiais e atividades humanas, que se estendem por centenas de metros ou quilômetros. Cada LCZ tem um regime de $T_{\text {ar }}$ característico que é mais evidente sobre superfícies secas, em noites claras com pouco vento e em áreas de relevo simples (STEWART; OKE, 2012). Apesar da caracterização das LCZs ser, por definição, realizada por meio do contraste entre a $T_{\text {ar }}$ de cada classe, a falta de uma densa e confiável rede de monitoramento levou à utilização da $T_{\text {sup }}$ obtida via SR como alternativa (CAl et al., 2018; GELETIČ; LEHNERT; DOBROVOLNÝ, 2016; LIN; XU, 2016; ZHAO, 2018).

Cada LCZ possui ainda diferentes características, como densidade, porcentagem de área impermeável, rugosidade, fator de visão de céu, materiais de revestimento etc., além de comportamento termal característico. O esquema de classificação propõe 17 zonas, 
sendo 10 utilizadas para definir as tipologias de edificação (Tabela 4), e 7 para definir as coberturas do solo Tabela 5 .

Tabela 4. Local Climate Zones (LCZ). Tipologias construídas. Adaptado de Stewart e Oke (2012).

\begin{tabular}{ll}
\hline Tipologia Construtiva & Definição \\
\hline LCZ 1. Alto-compacto & $\begin{array}{l}\text { Edifícios altos em arranjo compacto. Áreas densamente construídas, com edifícios com mais de } 10 \\
\text { pavimentos. Cobertura do solo predominantemente impermeável, com pouca ou nenhuma } \\
\text { vegetação. Materiais predominantes: concreto, aço, pedras e vidros. }\end{array}$ \\
\hline LCZ 2. Médio-compacto & $\begin{array}{l}\text { Edifícios de altura média em arranjo compacto. Áreas densamente construídas, com edifícios de } 3 \\
\text { a pavimentos. Cobertura do solo predominantemente impermeável, com pouca ou nenhuma } \\
\text { vegetação. Materiais predominantes: concreto, pedras, tijolos e materiais cerâmicos. }\end{array}$ \\
\hline LCZ 3. Baixo-compacto & $\begin{array}{l}\text { Edifícios baixos em arranjo compacto. Áreas densamente construídas, com edifícios de } 1 \text { a } 3 \\
\text { pavimentos. Cobertura do solo predominantemente impermeável, com pouca ou nenhuma } \\
\text { vegetação. Materiais predominantes: concreto, pedras, tijolos e materiais cerâmicos. }\end{array}$ \\
Edifícios altos em arranjo aberto. Áreas de menor adensamento, com edifícios com mais de 10 \\
pavimentos. Abundância de áreas permeáveis (com vegetação herbácea, arbustiva ou arbórea \\
esparsa). Materiais predominantes: concreto, aço, pedras e vidros.
\end{tabular}

Edifícios de altura média em arranjo aberto. Áreas de menor adensamento, com edifícios de 3 a 9
pavimentos. . Abundância de áreas permeáveis (com vegetação herbácea, arbustiva ou arbórea
esparsa). Materiais predominantes: concreto, aço, pedras e vidros.

$\begin{array}{ll}\text { LCZ 6. Baixo-aberto } & \text { Edifícios baixos em arranjo aberto. Áreas de menor adensamento, com edifícios de } 1 \text { a } 3 \\ \text { pavimentos. Abundância de áreas permeáveis (com vegetação herbácea, arbustiva ou arbórea } \\ \text { esparsa). Materiais predominantes: concreto, pedras, tijolos, madeira e materiais cerâmicos. }\end{array}$

\begin{tabular}{ll}
\hline LCZ 7. Baixo-precário & $\begin{array}{l}\text { Edifícios baixos e leves, com pouca inércia térmica. Áreas densamente construídas, pouco } \\
\text { consolidadas, com edifícios de } 1 \text { pavimento. Pouca ou nenhuma vegetação arbórea. Cobertura do } \\
\text { solo predominantemente compacta. Materiais predominantes: madeira, palha e metal corrugado. }\end{array}$ \\
\hline LCZ 8. Baixo-grande & $\begin{array}{l}\text { Grandes construções de baixa altura em arranjos abertos. Edifícios de } 1 \text { a } 3 \text { pavimentos, com } \\
\text { cobertura do solo predominantemente impermeável. Materiais predominantes: aço, concreto, } \\
\text { metal ou pedra. }\end{array}$
\end{tabular}

\begin{tabular}{l}
\hline LCZ 9. Ocupação esparsa \\
arranjos esparsos de edifícios de baixa ou média altura em ambientes naturais. Abundância de \\
\hline LCZ 10. Indústria pesada
\end{tabular}


Tabela 5. Local Climate Zones (LCZ). Tipologias de cobertura do solo. Adaptado de Stewart e Oke (2012).

\section{Tipologia de cobertura do solo Definição}

LCZ A. Veg. Arbórea densa

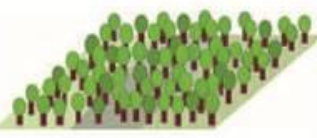

Áreas densamente cobertas por vegetação arbórea decídua e/ou perene. Cobertura de solo predominantemente permeável, com vegetação herbácea. Exemplos: florestas naturais ou cultivadas, parques urbanos.

LCZ B. Veg. Arbórea esparsa

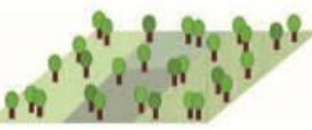

Áreas cobertas por vegetação arbórea esparsa decídua e/ou perene. Cobertura de solo predominantemente permeável, com vegetação herbácea. Exemplos: florestas naturais ou cultivadas, parques urbanos.

LCZ C. Veg. arbustiva

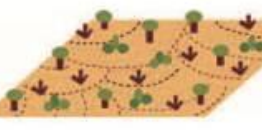

LCZ D. Veg. herbácea

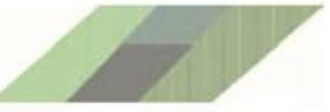

LCZ E. Rocha ou pavimento

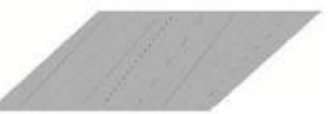

LCZ F. Solo exposto

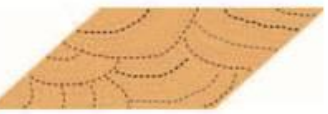

LCZ G. Água

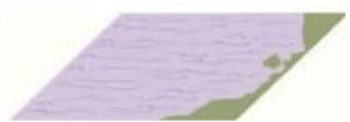

Áreas cobertas por esparsa vegetação arbustiva e vegetação arbórea de pequeno porte. Cobertura de solo predominantemente permeável (solo exposto ou areia). Exemplo: áreas arbustivas naturais ou áreas de cultivo agrícola.

Áreas cobertas por vegetação herbácea. Exemplo: pastagens naturais ou cultivadas, áreas agrícolas ou parques urbanos.

Áreas cobertas por rochas ou pavimentos impermeáveis. Pouca ou nenhuma vegetação.

Exemplo: rochas expostas e áreas destinadas a transporte.

Áreas cobertas por solo exposto ou areia. Pouca ou nenhuma vegetação. Exemplo: desertos ou áreas agrícolas.

Corpos d'água: oceanos, lagos, rios, represas e lagoas.

A classificação das cidades em LCZs tem sido adotada por vários trabalhos, tanto aqueles produzidos por climatologistas e geógrafos, quanto os produzidos por arquitetos urbanistas (BECHTEL et al., 2015; CAl et al., 2018; GELETIC; DOBROVOLNY; LEHNERT, 2017; GELETIČ; LEHNERT; DOBROVOLNÝ, 2016; MASSON et al., 2015; PERERA; EMMANUEL, 2015; REN et al., 2016; ZHENG et al., 2018). A grande difusão da metodologia entre os pesquisadores de clima urbano possibilita a comparação entre as cidades que adotaram a metodologia. 
Existem diferentes formas para a elaboração de um mapa LCZ, que variam desde um mapeamento manual até classificações automáticas de grandes regiões. Uma das metodologias mais difundidas é a proposta por Bechtel et al. (2015) adotada pelo World Urban Database and Access Portal Tool (WUDAPT) ${ }^{24}$. Esta metodologia consiste em gerar um mapa de LCZs a partir da classificação automática de imagens do satélite LANDSAT, usando áreas de treinamento definidas pelo usuário no software Google Earth. A partir das áreas de treinamento escolhidas (no mínimo cinco amostras de cada classe, cada uma com área superior a $100 \mathrm{~m}^{2}$ ), o classificador Local Climate Zones Classification, presente na versão 2.2.0 do software SAGA GIS, executa a classificação para toda a área escolhida.

Com o intuito de avaliar as vantagens da adoção da classificação LCZ para a RMSP, Ferreira et al. (2017) compararam dois mapas de UOS existentes para a RMSP e o mapa de LCZ produzido pelos autores, de acordo com a metodologia proposta por Bechtel et al. (2015)e adotada pelo WUDAPT.

Os mapas de UOS existentes para a RMSP foram produzidos pela Empresa de Planejamento Metropolitano de São Paulo (EMPLASA) em 2002/03 e pelo Laboratório QUAPA (Quadro do Paisagismo no Brasil da Faculdade de Arquitetura e Urbanismo da Universidade de São Paulo) em 2015. Ambos possuem classes diferentes, o que desafia a comparação entre eles, que foi realizada visualmente a partir do agrupamento das classes de UOS em classes semelhantes ou equivalentes às classes LCZ e da atribuição das mesmas cores. O mapa da EMPLASA possui apenas quatro classes para descrever a área construída e as classes do mapa produzido pelo QUAPA não consideram a vegetação das ruas e dos jardins privados e não abrangem a área total da RMSP. Apesar da metodologia usada para gerar os mapas de UOS terem uma alta precisão, o tempo para sua produção é alto, o que torna sua atualização contínua bastante improvável (FERREIRA et al., 2017).

A comparação realizada entre os três mapas (Figura 23 à Figura 26) identificou que, apesar da menor precisão do mapa LCZ na escala da quadra, foi possível identificar os padrões morfológicos urbanos da RMSP. Portanto, os autores concluíram que tal metodologia oferece uma combinação de precisão satisfatória em escala local, baixo

\footnotetext{
${ }^{24}$ O World Urban Database and Access Portal Tools é uma iniciativa para a coleta de dados sobre diferentes cidades do mundo utilizando uma metodologia comum, com o objetivo de fornecer subsídios para estudos de clima presente e futuro.
} 
tempo e custo de produção, o que permite sua atualização de forma relativamente simples.
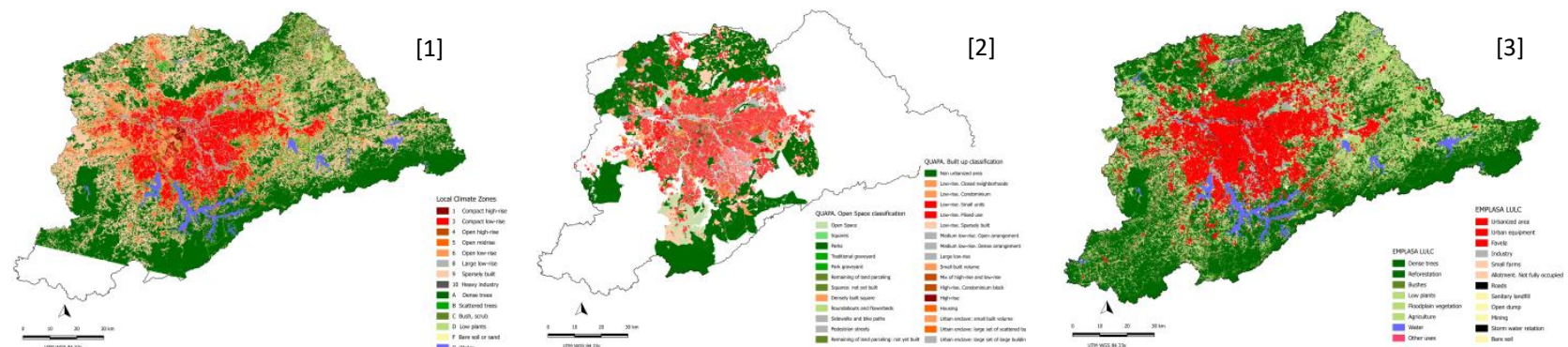

Figura 23. Mapas de UOS e LCZ da RMSP. [1] Mapa LCZ [2] Mapa QUAPA [3] Mapa EMPLASA. Fonte: Ferreira et al. (2017)
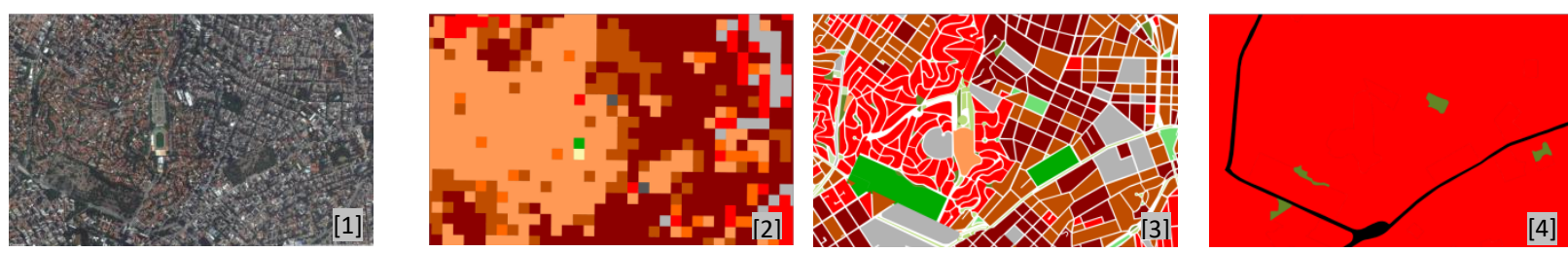

Figura 24. Comparação entre os mapas. Bairro do Pacaembu, São Paulo. [1] Imagem Google Earth [2] Mapa LCZ [3] Mapa QUAPA

[4] Mapa EMPLASA. Fonte: Ferreira et al. (2017).
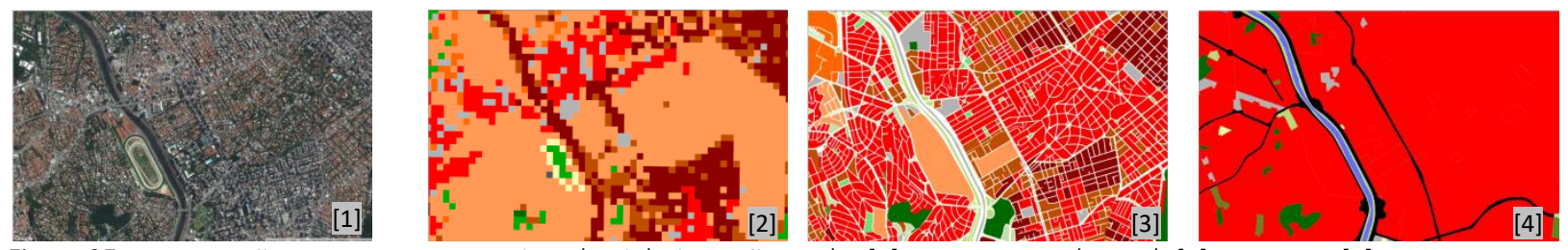

Figura 25. Comparação entre os mapas. Bairro de Pinheiros, São Paulo. [1] Imagem Google Earth [2] Mapa LCZ [3] Mapa QUAPA

[4] Mapa EMPLASA. Fonte: Ferreira et al. (2017).
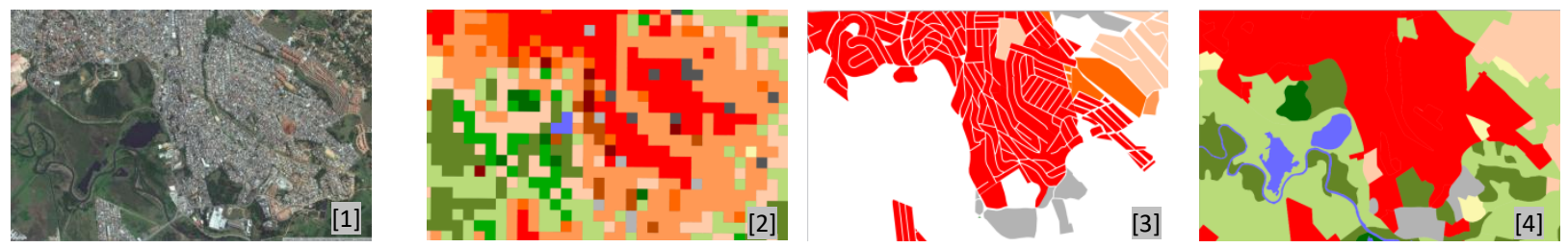

Figura 26. Comparação entre os mapas. Município de Suzano. [1] Imagem Google Earth [2] Mapa LCZ [3] Mapa QUAPA [4] Mapa EMPLASA. Fonte: Ferreira et al. (2017). 


\section{MATERIAIS E MÉTODO DA PESQUISA}

Este capítulo apresenta os materiais e o método utilizados na pesquisa. São apresentadas as formas de aquisição dos dados, os processamentos executados e modelos utilizados.

O impacto da vegetação e da morfologia urbana nas temperaturas de superfície diurnas e noturnas foi abordado espacial e temporalmente. Em termos espaciais buscou-se verificar as diferentes respostas termais em áreas com coberturas vegetais e morfologias distintas em um dado instante. A análise temporal buscou verificar a tendência de comportamento da temperatura de superfície $\left(T_{\text {sup }}\right)$ e dos índices de vegetação entre 2003 e 2017, verificando as relações entre alterações de vegetação e temperatura. Foram realizadas análises de tendência para os dois índices de vegetação considerados, NDVI e EVI, e para a $T_{\text {sup }}$ diurna e noturna. As alterações morfológicas foram analisadas por meio da detecção de alterações nos mapas de morfologia elaborados para os anos de 2003, 2010 e 2017.

\subsection{Dados de sensores remotos}

\subsubsection{Aquisição e recorte}

Conforme descrito no Capítulo 2, O SR apresenta diversas vantagens para estudos climáticos e de vegetação urbana na escala local. A escolha do sensor utilizado na pesquisa considerou a resolução temporal, a disponibilidade de imagens noturnas e a disponibilidade gratuita de dados. A disponibilidade de dados noturnos configura fator relevante, uma vez que estes são de grande interesse para análises dos padrões de ocupação urbana e sua relação com fenômenos de aquecimento.

A resolução temporal mostrou-se especialmente importante para os estudos de $T_{\text {sup. }}$. De acordo com Sousa e Ferreira, (2012), por ser a $T_{\text {sup }}$ uma variável dinâmica, é necessária a utilização de grande quantidade de informações para que se possa confirmar ou descartar tendências. De fato, a utilização de poucas imagens termais pode produzir equívocos de 
análise, caso os dias escolhidos para o estudo não sejam dias típicos e de estabilidade atmosférica.

O sensor que melhor atendeu os critérios estabelecidos foi o MODIS (Moderate Resolution Imaging Spectroradiometer), que se encontra a bordo dos satélites Terra e Aqua. Ambos fornecem imagens de toda a superfície terrestre com intervalo de 1 a 2 dias, sendo as imagens do satélite Terra adquiridas aproximadamente às $10 \mathrm{~h} 30$ e às $22 \mathrm{~h} 30$ e as imagens do satélite Aqua às $13 \mathrm{~h} 30$ e à $1 \mathrm{~h} 30$ (hora solar). Esta pesquisa utilizou dados do satélite Aqua por seu horário de passagem diurno ser mais próximo ao horário de máxima $T_{a r}$ e seu horário de passagem noturno ser mais próximo ao horário de mínima $T_{a r}$.

Foram utilizados os produtos AQUA MODIS de $\mathrm{T}_{\text {sup }}$ e índices de vegetação: produto MYD11A2 (MODIS/Aqua LST/Emissivity 8-Day L3 Global 1 km SIN Grid V006, resolução espacial de $1 \mathrm{~km}$ ) e produto MYD13Q1 (MODIS/Aqua Vegetation Indices 16-Day L3 Global 250m SIN Grid V006, resolução espacial de 250m).

O produto de $T_{\text {sup }}$ apresenta a média da $T_{\text {sup }}$ em um intervalo de oito dias para cada pixel da imagem, já o produto de índices de vegetação apresenta a melhor resposta obtida para cada pixel em um intervalo de 16 dias.

Todas as imagens entre 22/setembro/2002 e 06/setembro/2017 foram adquiridas gratuitamente na plataforma Earth Data do National Aeronautics and Space Administration (NASA) <https://search.earthdata.nasa.gov/search>, compreendendo 46 imagens por período (diurno e noturno) por ano para o produto de $\mathrm{T}_{\text {sup }}$ e 23 imagens por índice (NDVI e EVI) por ano para o produto de índices de vegetação, totalizando respectivamente 1380 e 690 imagens. Após alguns testes com diferentes métodos para obtenção das imagens $^{25}$, estas foram adquiridas em formato Geotiff na projeção sinusoida $\left.\right|^{26}$.

\footnotetext{
${ }^{25}$ No início da pesquisa as imagens foram adquiridas por meio do pacote MODISTOOL para execução direta no programa R; porém, além de não funcionar adequadamente com a versão mais recente dos dados MODIS (V006), o pacote foi descontinuado temporariamente. Assim, optou-se pela aquisição das imagens diretamente da plataforma MODIS/VIIRS Subsets <https://modis.ornl.gov/>. Todas as imagens foram adquiridas no formato Geotiff e na projeção LAT/LONG Datum WGS84; porém verificou-se posteriormente que as imagens nessa projeção apresentavam discordância entre os dados de temperatura e a banda de qualidade correspondente, ou seja, pixels com dados contaminados com nuvens apresentavam índice de qualidade alto e vice-versa. Em contato com a equipe técnica do site constatou-se que o problema possivelmente ocorria no processo de reprojeção executado pelo próprio site, no qual valores dos pixels são interpolados com os de seus vizinhos, fazendo com que pixels com temperatura negativa "contaminem" pixels contíguos. O mesmo não ocorria com os valores da banda de qualidade, uma vez que estes são todos
} 
Após a aquisição as imagens foram recortadas de acordo com os limites da RMSP, obtidos em arquivo vetorial em formato Esri Shapefile junto ao Centro de Estudos da Metrópole $\left(\mathrm{CEM}^{27}\right)$.

\subsubsection{Processamento inicial}

\subsubsection{Análise da qualidade das imagens e dados ausentes}

Após o download, todas as imagens foram filtradas pela banda de qualidade (quality control ou QC) fornecida junto com os produtos MODIS. Essa banda fornece informações sobre a qualidade do dado, pixel a pixel. No produto de $T_{\text {sup }}$ foram excluídos pixels contaminados por nuvens e com erro igual ou superior a 3K, por decisão desta pesquisa. No produto índices de vegetação foram excluídos pixels não processados ou contaminados por nuvens. Todo o procedimento foi executado no programa $R$ ( $R$ CORE TEAM, 2018) ${ }^{28}$.

Mesmo após a aplicação de filtro pela banda de qualidade foram identificadas temperaturas abaixo de $273,15 \mathrm{~K}\left(0^{\circ} \mathrm{C}\right)$ no produto de $\mathrm{T}_{\text {sup }}$ em três cenas diurnas e seis cenas noturnas, evidenciando erro, dado que não ocorrem temperaturas superficiais dessa ordem na área de estudo. Ao examinar o dado de qualidade associado aos pixels com tais temperaturas observou-se que todos possuíam boa qualidade, evidenciando erro na banda de qualidade fornecida pelo próprio MODIS. As cenas corrompidas correspondem a $0,65 \%$ do total de cenas utilizadas nesta pesquisa e o número de pixels afetado em cada uma das cenas corrompidas corresponde, em média, a 0,042\% da cena, não ultrapassando 0,3\%. Dada a pequena quantidade de imagens afetadas e o baixo percentual corrompido em cada cena, pode-se considerar que não há comprometimento do processo de filtragem pela banda de qualidade utilizado nessa pesquisa.

\footnotetext{
valores positivos. Todas as imagens foram novamente adquiridas, desta vez da plataforma Earth Data, no formato Geotiff e na projeção sinusoidal. Todos os processamentos e cálculos realizados no decorrer da pesquisa foram executados em projeção sinusoidal para evitar problemas de interpolação. Nos procedimentos que envolviam arquivos vetoriais no formato Esri shapefile, estes arquivos foram convertidos para a projeção sinusoidal. Com os cálculos já concluídos, os mapas foram então reprojetados para a projeção Universal Transversa de Mercator (UTM), fuso 23 Sul, datum horizontal SIRGAS2000.

26 Projeção padrão de aquisição dos dados MODIS.

${ }^{27}$ http://web.fflch.usp.br/centrodametropole/

${ }^{28} \mathrm{R}$ é um programa, mas também uma linguagem de programação, que incorpora processamentos gráficos e estatísticos. Disponível em: https://www.r-project.org/
} 
A Tabela 6 identifica as cenas nas quais este erro foi observado, a quantidade de pixels corrompidos e o percentual de erro na cena.

Tabela 6. Cenas com pixels corrompidos após aplicação da banda de qualidade.

\begin{tabular}{|c|c|c|}
\hline Cena (ano/DOY ${ }^{29}$ ) & Quantidade de pixels corrompidos & Percentual da cena corrompida \\
\hline 2013/009 (diurno) & 3 & $0,006 \%$ \\
\hline 2013/033 (diurno) & 14 & $0,027 \%$ \\
\hline 2016/353 (diurno) & 4 & $0,008 \%$ \\
\hline 2003/241 (noturno) & 2 & $0,004 \%$ \\
\hline 2004/153 (noturno) & 4 & $0,008 \%$ \\
\hline 2004/161 (noturno) & 7 & $0,013 \%$ \\
\hline 2007/209 (noturno) & 3 & $0,006 \%$ \\
\hline 2009/145 (noturno) & 4 & $0,008 \%$ \\
\hline 2012/265 (noturno) & 157 & $0,299 \%$ \\
\hline
\end{tabular}

As cenas corrompidas foram tratadas individualmente e os pixels com temperaturas abaixo de $273,5 \mathrm{~K}\left(0^{\circ} \mathrm{C}\right)$ foram excluídos.

O procedimento de filtragem dos dados, apesar de necessário, exclui informações. Na área de estudo desta pesquisa, a presença de nuvens é maior durante os meses de verão e primavera. Já os erros acima de 3Ksão mais frequentes na área urbanizada.

De acordo com Wan (1999), a $\mathrm{T}_{\text {sup }}$ calculada a partir dos dados MODIS, utiliza o algoritmo "split-window". Esse algoritmo usa as bandas 31 (faixa espectral $10.780-11.280 \mu \mathrm{m}$ ) e 32 (faixa espectral 11.770 - $12.270 \mu \mathrm{m}$ ), três coeficientes que são dependentes do ângulo de visão do sensor, da coluna de vapor d'água e do intervalo de $\mathrm{T}_{\mathrm{ar}}{ }^{30}$. Diferenças entre as respostas das bandas 31 e 32 pode provocar erro, porém não é especificado a partir de qual diferença esse erro poderia ocorrer. Erros podem ser provocados ainda pela quantidade de vapor de água na atmosfera e pelos seguintes fatores:

- Variações espaciais nas temperaturas dentro de um mesmo pixel. Isso significa que pixels mais heterogêneos, com maiores contrastes de temperatura no "sub-pixel" poderiam apresentar maior erro, bem como pixels com grandes áreas sombreadas e, portanto maior contraste de temperatura;

${ }^{29}$ O DOY - Day of Year, enumera os dias do ano em ordem sequencial. Os produtos MODIS são nomeados pelo primeiro dia do intervalo de 8 ou 16 dias que representam.

${ }^{30}$ A documentação técnica do MODIS não apresenta detalhes sobre a aquisição dos dados de $T_{a r}$. 
- Efeito de cirrus;

- A confiança na classificação da cobertura da Terra (que é dada em outro produto MODIS).

A ausência de dados nas imagens termais foi objeto de análise em diferentes fases da pesquisa. Inicialmente o ano de 2003 foi escolhido para uma análise detalhada dos tipos de erros presentes nas imagens. A Figura 27 exemplifica o tipo de análise efetuado. Cada imagem corresponde a um intervalo de 8 dias (determinado pelo DOY) e apresenta os dados aceitos e os excluídos por tipo de erro, se erros por presença de nuvens ou erros de temperatura e emissividade.

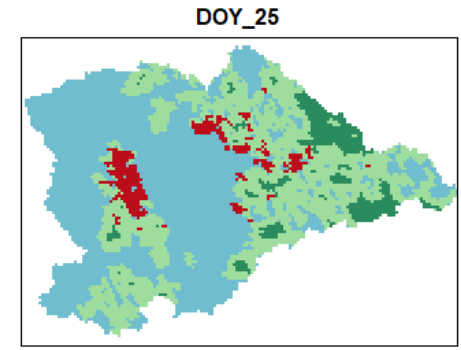

$\square 0 \quad \square 2 \quad \square \quad 17 \quad \square \quad 33 \quad \square 65$ DOY_41

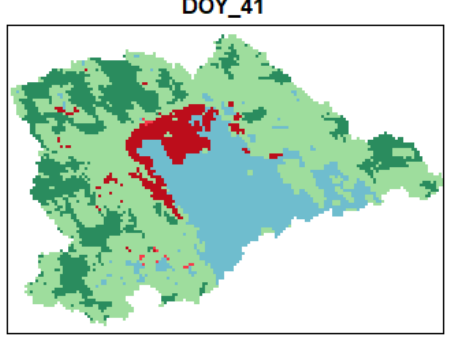

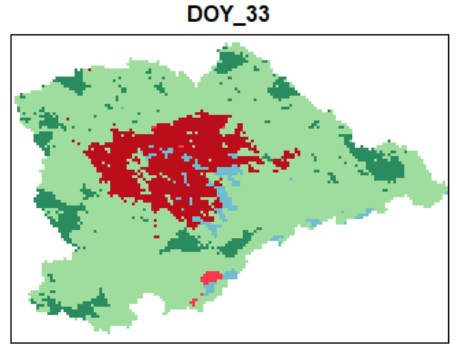

$\square 81$

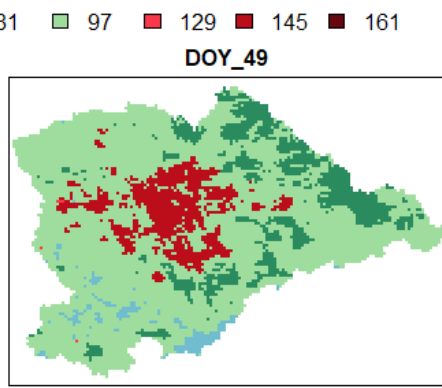

QUALITY (from QC layer)

0 - LST produced, good quality, not necessary to examine more detailed

2 - LST not produced due to cloud effects | DATA EXCLUDED

17:97 - Good data, emissivity error $<=0.01$ and $<=0.02$, LST error $<=2 \mathrm{~K}$

129 - Good data, emissivity error $<=0.01$, LST error $<=3 \mathrm{~K} \mid$ DATA EXCLUDED

145 - Good data, emissivity error $145-$ Good data, emissivity error
$<=0.02$, LST error $<=3$ K $\mid$ DATA EXCLUDED

161 - Good data, emissivity error $<=0.04$, LST error $<=3$ K $\mid$ DATA
EXCLUDED

Figura 27. Pixels ausentes por tipo de erro para o ano de 2003. Fonte: elaboração própria

Foi realiza ainda uma análise sobre a quantidade de dados ausentes por estação do ano.

As imagens médias, mostradas na Figura 28, para o verão e o inverno de 2003, foram compostas por 12 imagens cada. É possível verificar que no verão a imagem média é calculada com um número menor de dados do que no inverno, pelas razões já explicadas anteriormente neste capítulo. 

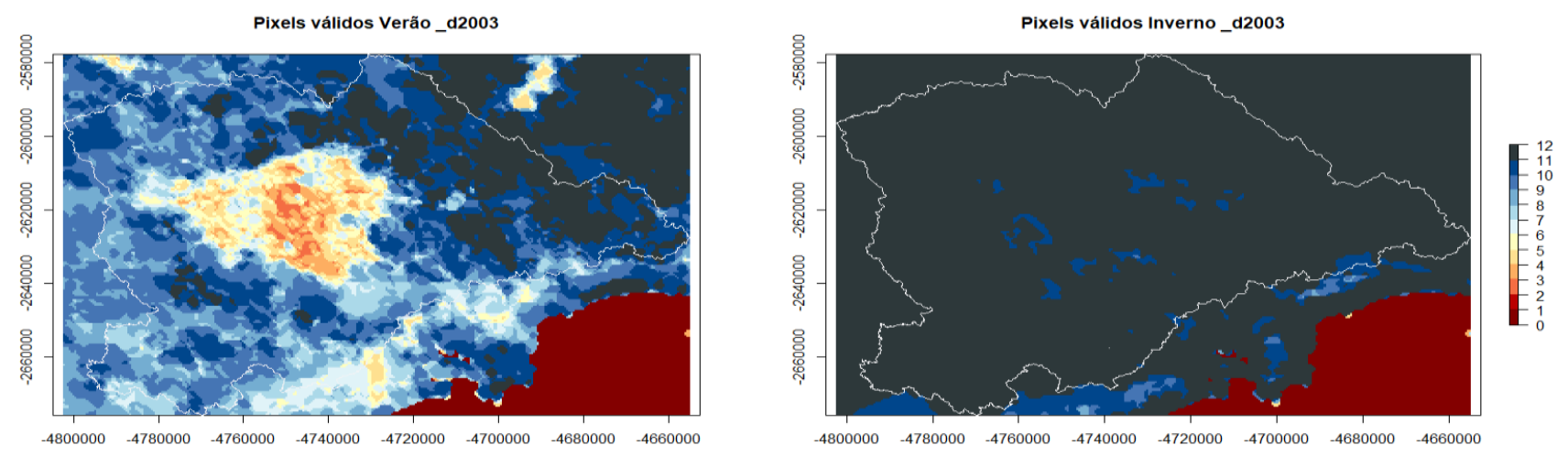

Figura 28. Quantidade de pixels válidos para o verão e o inverno de 2003. Fonte: elaboração própria

As análises realizadas para o ano de 2003 evidenciaram que:

- A área urbana não apresenta erro menor que $2 \mathrm{~K}$ em nenhuma imagem. Áreas de cobertura arbórea mais densa, ao contrário, apresentam dados com qualidade máxima de forma recorrente, sugerindo que incertezas na $T_{\text {sup }}$ são inerentes às áreas urbanas da RMSP;

- O erro mais recursivo é o descrito pelo valor $\mathrm{QC}=145$ - Good data, emissivity error $<=0.02$, LST error $<=3 \mathrm{~K}$;

- O inverno é a estação que apresenta menor erro.

Utilizando o mesmo procedimento feito para o ano de 2003, a quantidade de dados ausentes foi calculada para toda a série temporal:

Total de pixels (soma de todos os pixels de todas as imagens): 6.510 .348

Pixels excluídos por nuvens: $871.128(13,38 \%)$

Pixels excluídos por erros: 367.479 (5,64\%)

Total de pixels excluídos (nuvens e erros): 19,03\%

Os resultados para toda a série temporal indicaram que a maior causa de perda de dados são as nuvens. A ocorrência de nuvens, ao contrário dos erros, não possui um padrão espacial, por isso, apesar de representar a maior causa de contaminação dos dados, não impacta a análise tanto quanto os erros, que ocorrem de forma recorrente sobre a área urbana. 
Este tipo de ausência de dados é comum em trabalhos que utilizam sensores remotos. O preenchimento de dados ausentes na série temporal utilizando técnicas de gap filling, apesar de bastante comum no âmbito da análise da vegetação, não o é nas análises de $\mathrm{T}_{\text {sup. }}$ O preenchimento dos dados é complexo. Pode-se utilizar o valor de um pixel vizinho, do próprio pixel em outra data, a média do valor do pixel para toda a série temporal, entre outros. A primeira opção certamente imputaria erros dada a heterogeneidade da área de estudo. Já a segunda opção poderia dificultar a análise de áreas que sofreram alterações bruscas de temperatura. Assim, o preenchimento das séries foi descartado e optou-se por trabalhar com as séries temporais incompletas.

Para os estudos temporais, a incompletude da série dificultou a aplicação de análises estatísticas típicas para séries temporais. A solução encontrada, em conjunto com pesquisadores do Centro de Estatística Aplicada do Instituto de Matemática da Universidade de São Paulo (CEA IME/USP) foi trabalhar com a análise de regressão, ajustando a reta de regressão para cada pixel da imagem com o objetivo de capturar a tendência dos dados. Este procedimento será descrito no item 3.4.

Visando minimizar o impacto da ausência de dados nas análises espaciais optou-se por agrupar os dados em médias por estação seca e estação chuvosa, aumentando o número de amostras válidas por período em comparação à análise por média mensal ou sazonal considerando quatro estações. Assim, a estação chuvosa corresponde à primavera e ao verão e a estação seca, ao outono e ao inverno, sendo as datas de início e término das estações adequadas para as datas dos dados MODIS. Dessa forma a primeira estação chuvosa da série temporal analisada considerou os dados de 22 de setembro (DOY265) de 2002 a 28 de março (DOY88) de 2003 e assim sucessivamente, conforme a Figura 29. A última estação considerada foi a estação seca de 2017. 


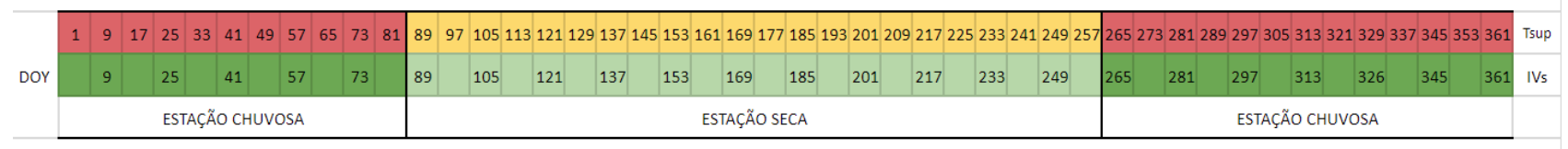

Figura 29. Divisão das estações seca e chuvosa de acordo com o dia do ano (DOY).

Após o agrupamento das imagens por estação seca e chuvosa a quantidade de dados faltantes foi ainda examinada de duas formas: pelo percentual de dados ausentes em uma cena e pelo percentual de dados utilizados para compor a média de cada pixel. Novamente a análise foi executada para um período teste (2003 a 2005). Para cada estação calculou-se o número de imagens com 90\%, 70\% e 50\% de informação válida. A Figura 30 exemplifica os três percentuais, obtidos em cenas de dias distintos, e a Tabela 7 apresenta os resultados da análise por percentual de dados válidos por cena para a RMSP.

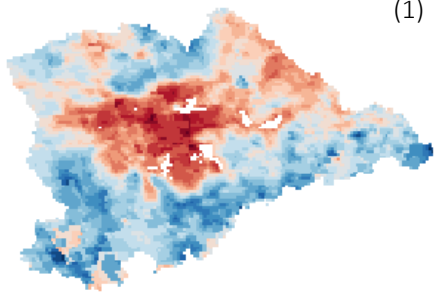
(1) Cena com $90 \%$ de dados válidos

(2) Cena com $70 \%$ de dados válidos

(2)
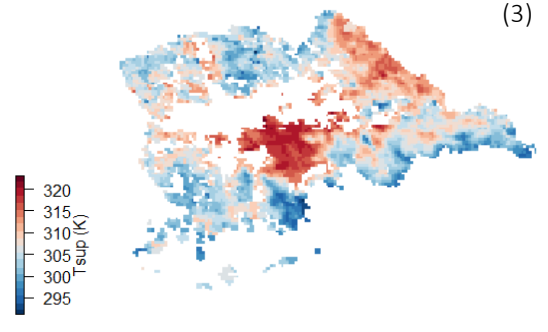

(3) Cena com $50 \%$ de dados válidos

(3)

Tabela 7. Análise do percentual de dados válidos para a RMSP (2003 a 2005).

\begin{tabular}{llll} 
& \multicolumn{2}{l}{ Quantidade de cenas existentes por percentual de dados válidos } \\
\hline & $90 \%$ & $70 \%$ & $50 \%$ \\
\hline Estação Seca 2003 & 18 cenas & 22 cenas & 22 cenas \\
(22 cenas) & $(82 \%)$ & $(100 \%)$ & $(100 \%)$ \\
\hline Estação Chuvosa 2003/04 & 4 cenas & 14 cenas & 22 cenas \\
(24 cenas) & $(17 \%)$ & $(58 \%)$ & $(92 \%)$ \\
\hline Estação Seca 2004 & 20 cenas & 22 cenas & 22 cenas \\
(22 cenas) & $(91 \%)$ & $(100 \%)$ & $(100 \%)$ \\
\hline Estação Chuvosa 2004/05 & 4 cenas & 14 cenas & 19 cenas \\
(24 cenas) & $(17 \%)$ & $(58 \%)$ & $(79 \%)$ \\
\hline
\end{tabular}

Em seguida, a mesma análise por percentual foi executada para cada pixel da imagem. Foram verificados quais pixels possuíam 90\%, 70\% e 50\% de amostras válidas para cada estação. Assim, para a estação chuvosa de 2003/04, por exemplo, para que um pixel apresente 90\% de amostras válidas são necessários 22 dados, para que apresente $70 \%$ são necessários 17 dados e para que apresente 50\%, 12. Porém, conforme mencionado 
anteriormente a ausência de dados nas áreas mais urbanizadas é maior do que nas áreas não urbanizadas, fazendo com que a exclusão de pixels com menos de um certo percentual de dados prejudique sobretudo as áreas mais centrais da RMSP, conforme ilustrado na Figura 31 que mostra a $T_{\text {sup }}$ média diurna para a estação chuvosa de 2003/04 calculada apenas com pixels que apresentaram mais de 12 ocorrências (50\%).

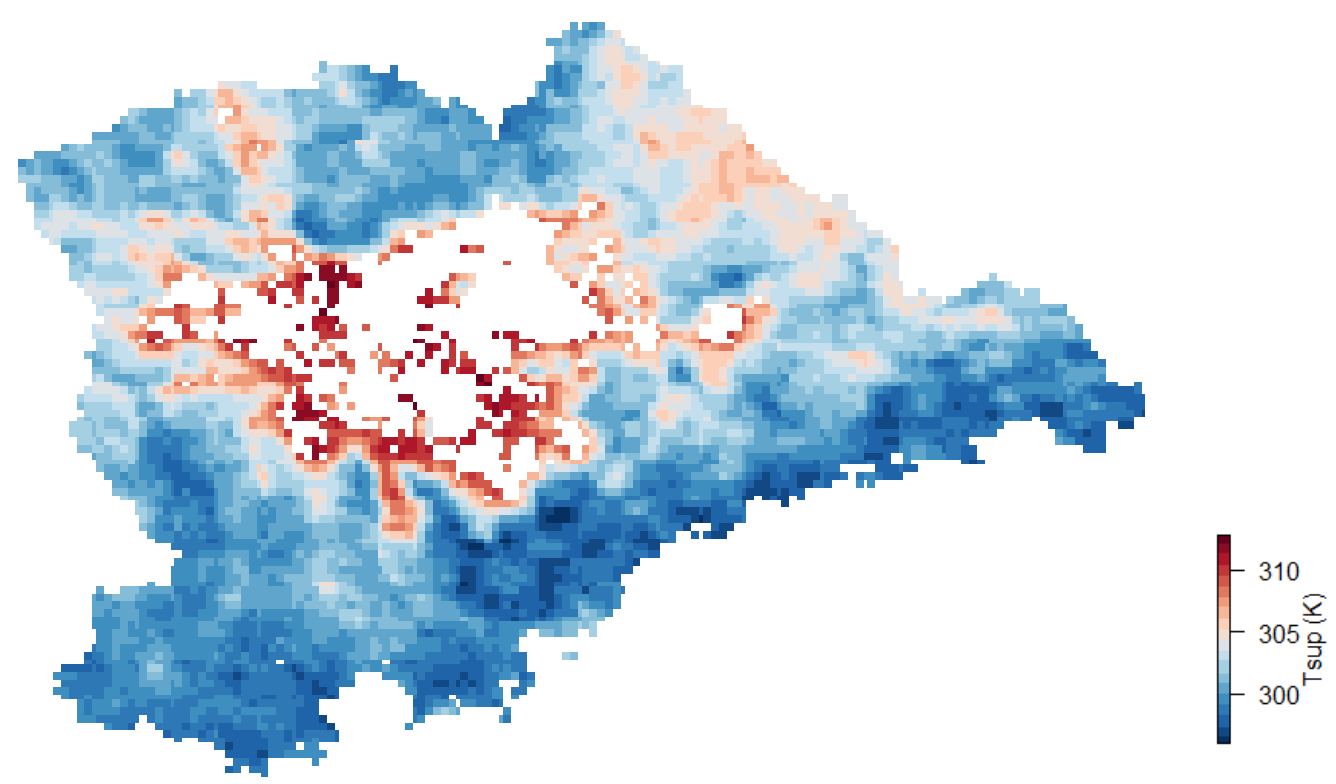

Figura 31. T Tup diurna média da estação chuvosa 2003/04 considerando-se apenas pixels com mais de 50\% de amostras válidas.

Após os testes descritos, optou-se pela utilização das cenas com mais de $50 \%$ de pixels válidos a fim de assegurar que cenas com poucos pixels (tanto por conta de grande cobertura de nuvens quanto por conta de baixa qualidade de dados) não fossem utilizadas para cálculo das imagens médias, sem com isso comprometer uma área geográfica específica, como acontece com a análise por pixel ilustrada na Figura 31.

\subsubsection{Corpos d'água}

Os principais corpos d'água da RMSP foram excluídos em todas as análises. Tendo em vista o comportamento característico da água, que se apresenta mais fria do que as superfícies construídas nas imagens termais diurnas, porém mais quente nas imagens noturnas, devido à sua capacidade térmica, optou-se pela exclusão dessas áreas a fim de centrar a análise nas superfícies secas, vegetadas e não vegetadas. 
Um arquivo vetorial em formato shapefile foi elaborado sobre imagem aérea de 2017 do programa Google Earth contendo o contorno dos rios Tietê e Pinheiros e das principais represas e lagos da RMSP. Dada a sazonalidade dos limites dos corpos d'água, algumas imprecisões nos limites foram verificadas e serão discutidas na análise dos resultados no Capítulo 4.

\subsubsection{Resolução espacial das imagens termais e dos índices de vegetação}

O produto MODIS termal e o produto índice de vegetação não possuem a mesma resolução espacial, a comparação entre essas duas imagens, por exemplo, por meio da análise de dispersão entre os dados, só é possível caso estas possuam a mesma resolução espacial. Assim, de acordo com a análise executada a resolução de um dos produtos teve de ser alterada, aumentado-a ou diminuindo-a.

A resolução das imagens de $T_{\text {sup }}$ foi alterada de $1 \mathrm{~km}$ para $250 \mathrm{~m}$ por meio da função resample do pacote raster do programa R (HIJMANS, 2018). O método utilizado para a reamostragem dos pixels foi a interpolação bilinear. A resolução das imagens dos índices de vegetação foi alterada de $250 \mathrm{~m}$ para $1 \mathrm{~km}$ por meio da função aggregate do pacote raster do programa R (HIJMANS, 2018) ${ }^{31}$. A função utilizada no processo de agregação foi a média simples.

A RMSP possui 9.274 pixels nas imagens com resolução espacial de $1 \mathrm{~km}$ e 148.396 pixels nas imagens com resolução espacial de $250 \mathrm{~m}$.

A Figura 32 e a Figura 33 apresentam, esquematicamente, o procedimento executado para as imagens do produto termal dos índices de vegetação do MODIS.

\footnotetext{
${ }^{31}$ O produto MYD13A3 também fornecido pelo Aqua MODIS apresenta os índices de vegetação já na resolução espacial de 1 km porém com dados médios mensais e por este motivo não foi utilizado nesta pesquisa.
} 


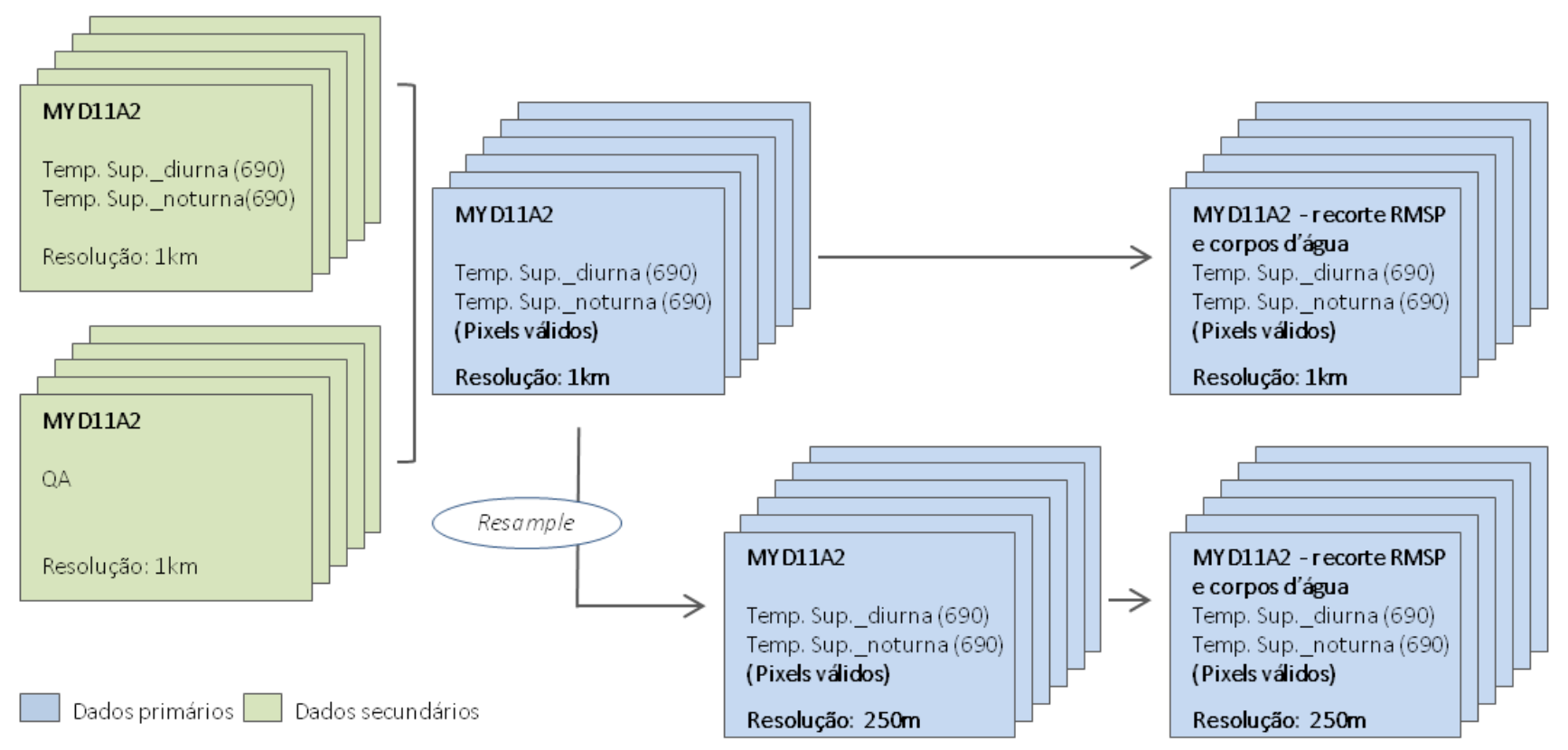

FunçãoR

Figura 32. Esquema do processamento executado para o produto termal (MYD11A2).

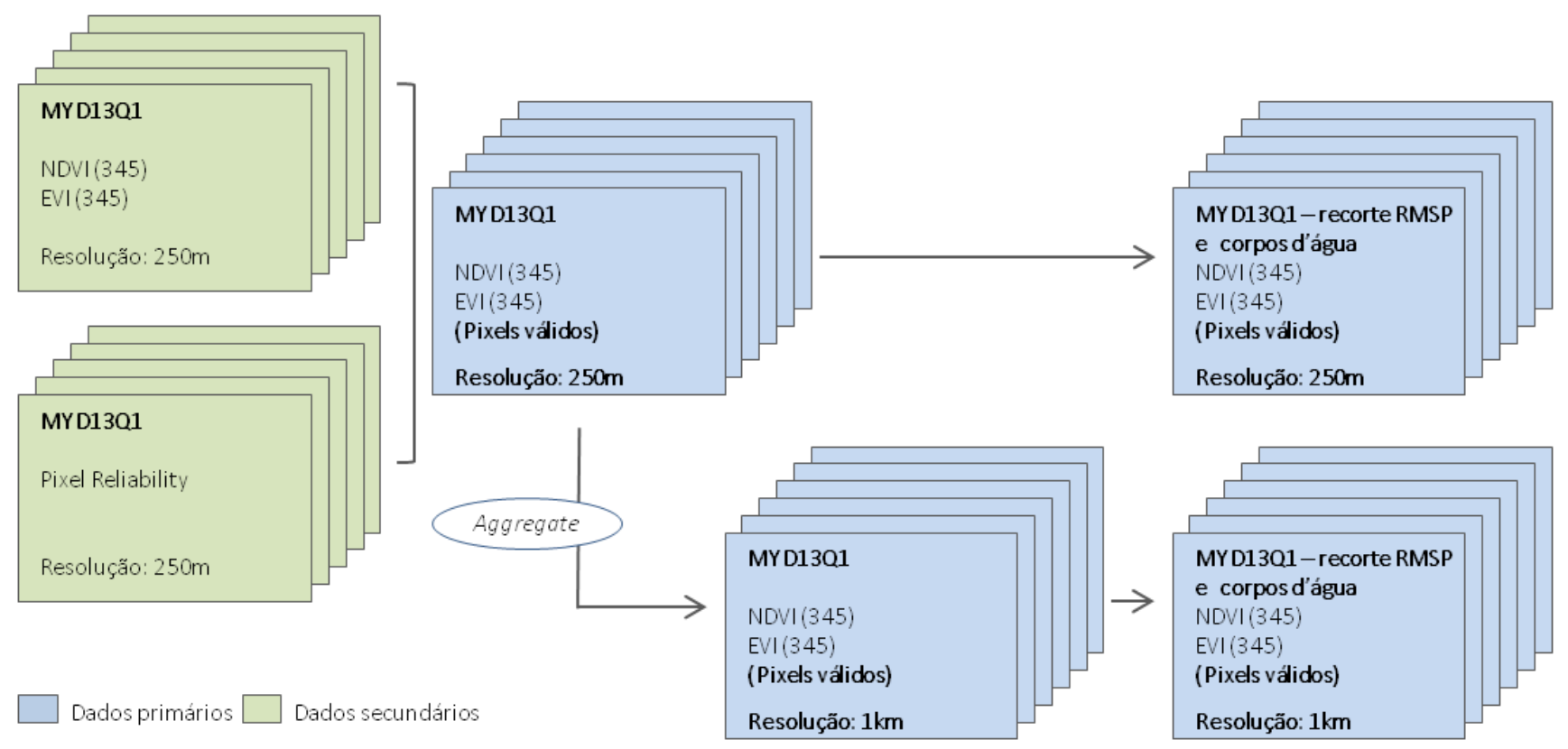

FunçãoR

Figura 33. Esquema do processamento executado para o produto índices de vegetação (MYD13Q1). 


\subsection{Morfologia Urbana}

A morfologia urbana foi analisada por meio da classificação da RMSP em local climate zones (LCZ), descrita no item 2.3 do presente trabalho. A elaboração dos mapas baseou-se no método proposto por Bechtel et al. (2015). Foram elaborados mapas para 2002, 2010 e 2017. Estes anos foram escolhidos, pois além de configurarem as extremidades e o centro da série temporal, possuem imagens de alta resolução, disponíveis em portais públicos, e que foram fundamentais para complementar as informações disponíveis no programa Google Earth durante o processo de seleção de áreas de treinamento e verificação da confiabilidade do mapa. Além disso, o ano de 2010 apresenta dados censitários que também foram utilizados no trabalho.

As áreas de treinamento para a classificação foram selecionadas no programa Google Earth, de modo que cada classe possui no mínimo cinco amostras de dimensão mínima de $100 \mathrm{~m}^{2}$. A classe 7 (Ocupação horizontal precária) e a classe 10 (Indústria pesada) não foram consideradas por não atenderem ao critério de quantidade e/ou tamanho das amostras na RMSP. Apesar do esquema de classificação das LCZ proposto por Stewart e Oke (2012) prever subclasses, compostas por duas classes "puras", nesta pesquisa foram usadas apenas as classes originalmente propostas pelos autores (Tabelas 4 e 5 Capítulo 2), tendo em vista ser esta a forma mais utilizada de classificação.

O primeiro mapa a ser elaborado foi o de 2017. As áreas de treinamento foram mantidas, sempre que possível, em todos os mapas. Para os anos de 2003 e 2010 foi utilizado o recurso de imagens históricas do Google Earth. Complementarmente às imagens do Google Earth foram usadas imagens IKONOS de 2002/2003 e imagem Ortorretificada 2010/2011 ambas disponibilizadas pela Secretaria do Meio Ambiente do Estado de São Paulo (SMA) no portal DataGEO ${ }^{32}$.

A classificação das imagens foi executada com o classificador Local Climate Zones Classification, presente na versão 2.2.0 do programa SAGA GIS. A classificação utilizou as

\footnotetext{
${ }^{32}$ As imagens IKONOS foram adquiridas pelo Instituto Geológico (IG-SMA) e as imagens ortorretificadas pela Empresa Paulista de Planejamento Metropolitano S.A (EMPLASA). Ambas possuem resolução espacial de $1 \mathrm{~m}$ e estão disponíveis em http://datageo.ambiente.sp.gov.br.
} 
cenas do satélite Landsat, descritas na Tabela 8 (path 219 rows 76 e 77). Para cada data utilizaram-se duas cenas contíguas devido à extensão da RMSP; assim, antes da classificação, foi necessário unir as cenas. Este procedimento foi executado separadamente para cada uma das bandas do Landsat no programa QGIS 2.14.18 e reamostradas para a resolução espacial de $100 \mathrm{~m}$ conforme sugerido por Bechtel et al. (2015). Este último procedimento é realizado durante o carregamento das imagens no programa SAGA GIS.

Tabela 8. Cenas dos satélites Landsat utilizadas para a elaboração dos mapas LCZ.

\begin{tabular}{lll} 
Ano & Satélite-Sensor & Datas \\
\hline 2017 & Landsat 8-OLI TIRS & 26 de Julho e 15 de Novembro \\
\hline 2010 & Landsat 5-TM & 18 de Abril e 5 de Maio \\
\hline 2002 & Landsat7-ETM+ & 20 de Abril e 7 de Junho \\
\hline
\end{tabular}

Apesar da metodologia proposta por Bechtel et al. (2015) recomendar a utilização de diversas cenas de épocas do ano distintas (cinco cenas para Landsat 8 e seis para Landsat 5), a disponibilidade de imagens da RMSP sem nuvens é bastante limitada, visto que a resolução temporal deste satélite é de 16 dias.

Conforme verificado por Prata-Shimomura e Ferreira (2018) para a Região Metropolitana de Ribeirão Preto (RMRP), a utilização de várias cenas Landsat para produção de mapas LCZ pode ocasionar problemas de classificação em áreas agrícolas, devido possivelmente à sazonalidade das culturas. Ao longo do ano uma mesma área pode ser classificada como vegetação arbustiva ou herbácea e, meses depois, como solo exposto. Os autores verificaram melhores resultados para a classificação da RMRP utilizando apenas uma cena.

Esta pesquisa testou, para o ano de 2017, a classificação usando uma, duas ou três cenas. Os melhores resultados para áreas urbanas e não urbanas foram obtidos utilizando-se duas cenas. A combinação de cenas também foi verificada. Foram usadas cenas de Julho, Setembro e Novembro. O melhor resultado foi obtido com as cenas de Julho e Novembro. Para os demais anos este teste não foi possível dada a inexistência de mais de duas cenas sem nuvens para toda a RMSP. As classificações também foram testadas usando-se diferentes áreas de treinamento. Cada mapa foi executado aproximadamente cinco vezes até a obtenção de um resultado aceitável. Os mapas foram confrontados visualmente 
com as imagens do Google Earth (2017), IKONOS (2002) ou imagens ortorretificadas (2010) usadas nas escolhas das áreas de treinamento e foram considerados aceitáveis quando a morfologia dos bairros e áreas verdes pôde ser representada na escala de interesse deste trabalho.

Vale destacar que o método de mapeamento em LCZ objetiva representar as morfologias predominantes na escala do bairro e que a resolução espacial das imagens Landsat é de $30 \mathrm{~m}$, reamostradas para $100 \mathrm{~m}$ de acordo com o método proposto para o WUDAPT, portanto, algumas limitações na classificação são esperadas.

Foram produzidos mapas LCZ com resolução espacial de $100 \mathrm{~m}$ e de $250 \mathrm{~m}$ Os primeiros foram utilizados para a caracterização espacial da morfologia urbana e para a verificação de alterações morfológicas entre os anos analisados: 2002 a 2010, 2010 a 2017 e 2002 a 2017.

Os mapas de $250 \mathrm{~m}$ de resolução espacial foram utilizados para as análises combinadas com a $T_{\text {sup }}$ e com os índices de vegetação. Inicialmente foram elaboradas análises com imagens de temperatura e índices de vegetação reamostrados para $100 \mathrm{~m}$, porém os resultados com as imagens de $250 \mathrm{~m}$ mostraram-se mais precisos.

\subsection{Análises Espaciais}

As análises espaciais tiveram por objetivo caracterizar a RMSP de acordo com as variáveis analisadas e verificar sua relação, como por exemplo as diferentes respostas termais diurnas e noturnas em áreas com diferentes índices de vegetação e morfologias. Para tanto, as temperaturas médias por estação seca e chuvosa foram confrontadas com os índices de vegetação médios por estação para todos os anos de analise, utilizando-se imagens com resolução espacial de $1 \mathrm{~km}$ e de $250 \mathrm{~m}$ e considerando-se todas as imagens ou apenas aquelas com mais de $50 \%$ de dados válidos, conforme descrito no item 3.1, para comparação dos resultados. Foram elaborados gráficos de dispersão, e também foram calculados o correspondente coeficiente de determinação, para as 30 estações analisadas (estação chuvosa 2002/2003 a estação seca 2017) com o objetivo de verificar 
tanto a natureza da relação entre temperatura e vegetação quanto se tal relação apresentou alteração durante o período de análise, especialmente nas estações com maiores temperaturas médias. A Figura 34 e a Figura 35 apresentam, esquematicamente, os procedimentos executados para as análises espaciais.

Para os anos de 2002, 2010 e 2017, foram computadas as $T_{\text {sup }}$ e os IVs para cada classe dos mapas de morfologia urbana, utilizando-se dados com resolução espacial de $250 \mathrm{~m}$.
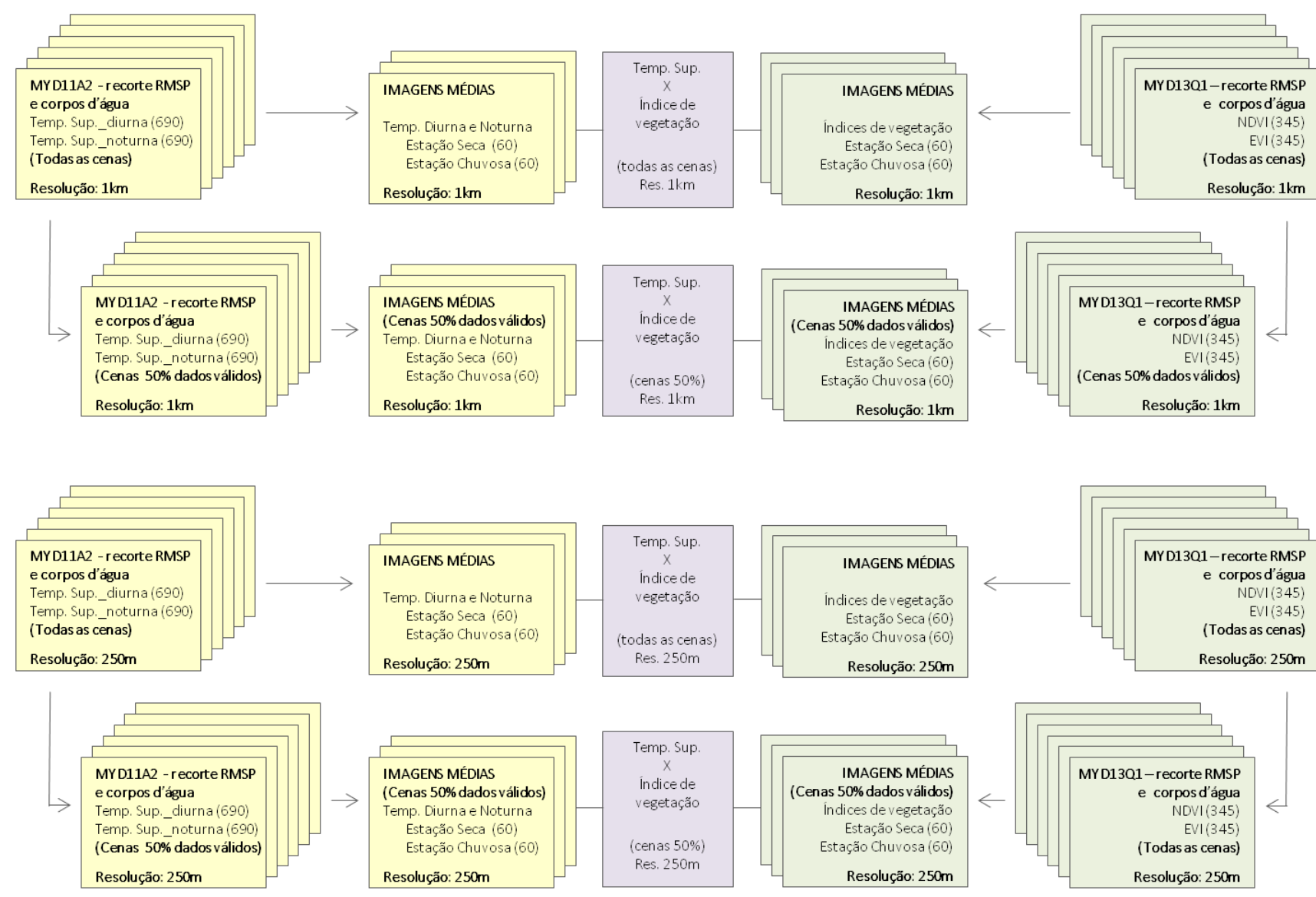

Figura 34. Diagrama do processamento executado. Análise espacial, imagens médias. 


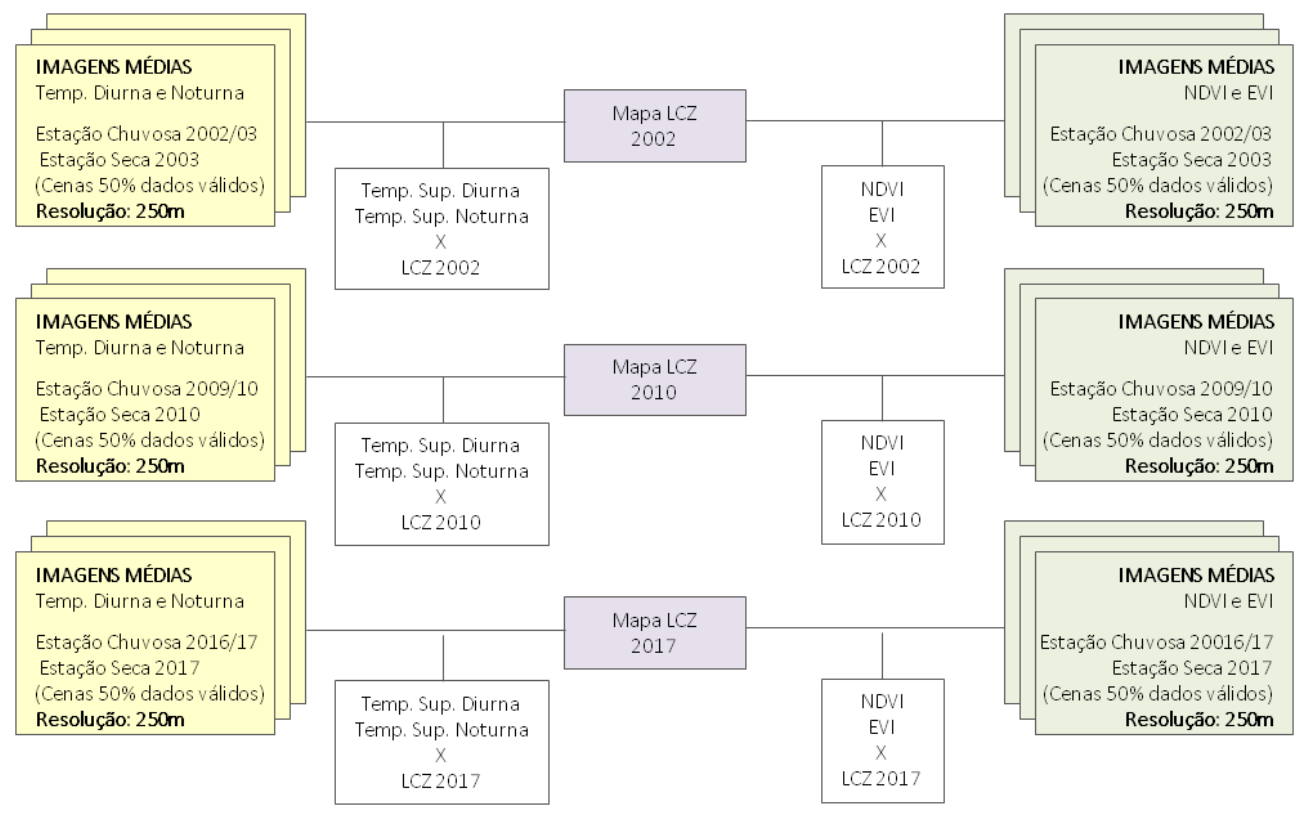

Figura 35. Diagrama do processamento executado. Análise espacial, imagens médias e LCZ.

A partir da $T_{\text {sup }}$ média calculada para toda a RMSP, foram identificados pixels com $T_{\text {sup }}$ acima e abaixo da média, buscando-se localizar áreas com comportamentos extremos. 


\subsection{Análises Temporais}

\subsubsection{Análise de mudanças na morfologia urbana}

Visando identificar alterações na morfologia urbana a partir dos três mapas LCZ elaborados, foram analisadas todas as possibilidades de alteração de classes para o período estudado que representassem alterações de vegetação.

Para tanto, foi considerada a quantidade de vegetação e espaço livre presente em cada classe, independente da altura das edificações, assim, uma área classificada como LCZ A (Vegetação Arbórea densa) que passa a ser classificada como LCZ 3 (Baixo-compacto) ou como LCZ 9 (Ocupação esparsa), ou ainda qualquer outra classe com menor quantidade de cobertura arbórea foi considerada como tendo sofrido perda de vegetação. Áreas classificadas como possível perda de vegetação são áreas que sofreram alteração dentro de uma mesma tipologia, ou seja, uma tipologia construtiva com maior presença de vegetação que passa a ser classificada como tipologia construtiva com pouca vegetação, ou áreas que passaram de uma tipologia construtiva com maior presença de vegetação para as classes de vegetação arbustiva ou herbácea. O mesmo método foi aplicado para o ganho de vegetação. A Tabela 9 apresenta as classes de alteração da vegetação.

Tabela 9. Classe de análise das alterações morfológicas.

\begin{tabular}{|c|c|c|c|}
\hline Cor & Classe & Cor & Classe \\
\hline & Área Urbana & & Sem alteração de vegetação \\
\hline & Ganho de Vegetação & & Corpo d’água \\
\hline & Possível ganho de vegetação & & Aumento do corpo d'água \\
\hline & Possível perda de vegetação & & Diminuição do corpo d'água \\
\hline & Perda de vegetação & & Alterações não significativas \\
\hline
\end{tabular}

O procedimento para execução do mapa consistiu em multiplicar o mapa da situação inicial por 100.000 e somar ao mapa da situação final, assim o resultado da conversão de uma classe em outra pôde ser facilmente interpretado, conforme o exemplo: 


\begin{tabular}{lll} 
Classe no Mapa 2002 & Classe no Mapa 2010 & Classe no Mapa de mudança \\
\hline 9 & 3 & 900003 \\
\hline 101 & 103 & 10100103 \\
\hline
\end{tabular}

O mapa foi produzido no programa ENVI $5.1^{33}$ e posteriormente editados no programa QGIS apenas para atribuição de escala, legenda e demais elementos visuais.

\subsubsection{Análise de tendência para a temperatura e superfície e índices de vegetação}

A ausência de dados na série temporal, discutida no item 3.1, levou à opção, em conjunto com os pesquisadores do CEA (IME/USP), pela análise da tendência da série temporal. Para tanto, foram considerados todos os dados disponíveis para cada pixel para toda a série e realizado o ajuste da reta de regressão linear simples. Este ajuste configura uma estimativa, como mostra a Figura 36, e seu objetivo é apenas capturar a tendência dos dados. Existe, portanto, um erro associado a essa estimativa. Para que a tendência pudesse ser considerada válida, foi estabelecido o intervalo de 95\% de confiança, que limita o erro a 1,96 vezes o desvio padrão (BARBETTA, 1994).

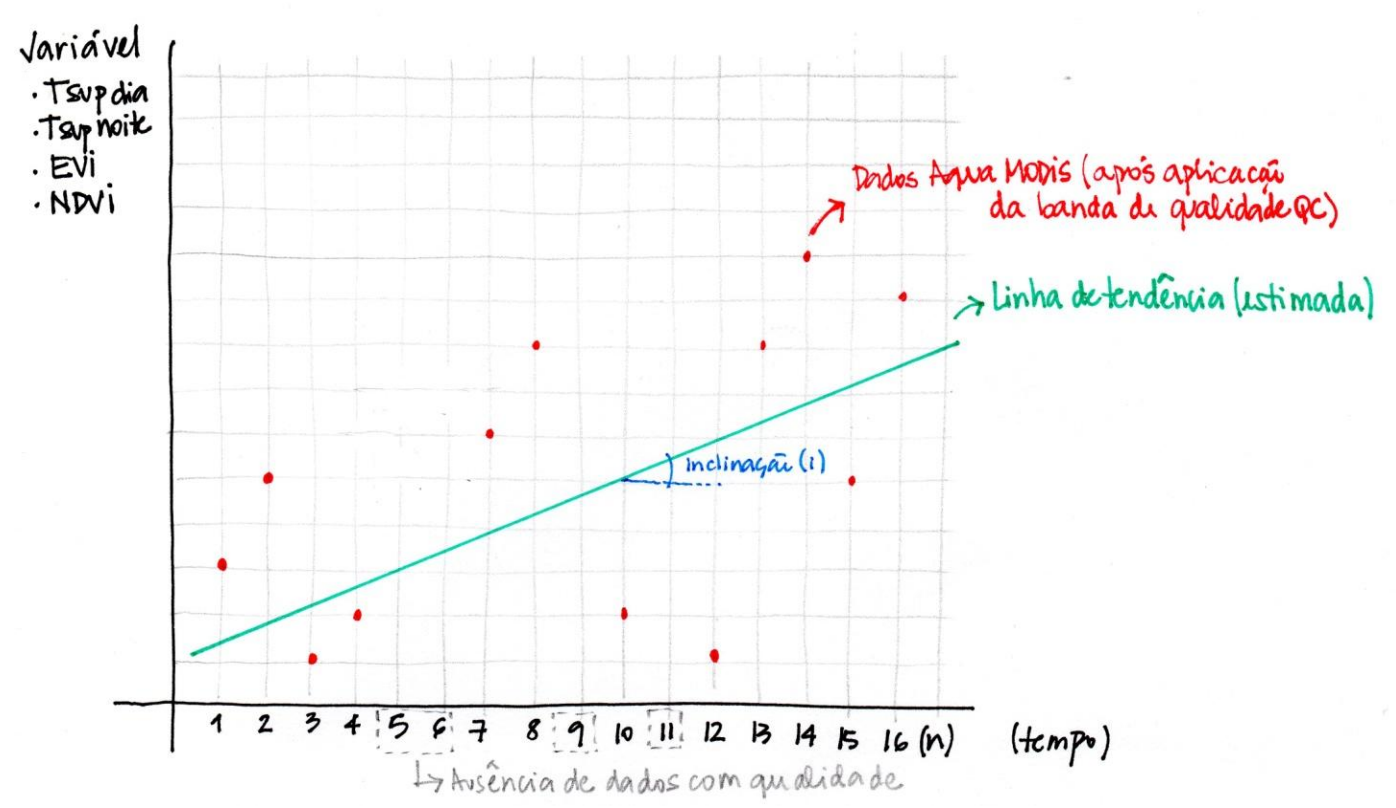

Figura 36. Análise de tendência. Diagrama explicativo: ajuste da reta de regressão linear.

\footnotetext{
33 Esse processamento é passível de ser executado em qualquer programa GIS. O ENVI foi utilizado apenas pelas facilidades que apresenta em relação ao QGIS para execução desse procedimento específico.
} 
Para que a tendência de uma variável para um determinado pixel fosse considerada positiva, o intervalo compreendido pela inclinação da reta de regressão linear somado ou subtraído o erro não poderia conter o valor zero, ou seja, o intervalo deveria ser totalmente positivo. De maneira análoga, para que a tendência de um determinado pixel fosse considerada negativa, o intervalo deveria estar todo abaixo do zero. Dessa forma, pôde-se concluir, com 95\% de confiança, que ocorreu aumento ou redução de uma das variáveis analisadas, como ilustra a Figura 37.

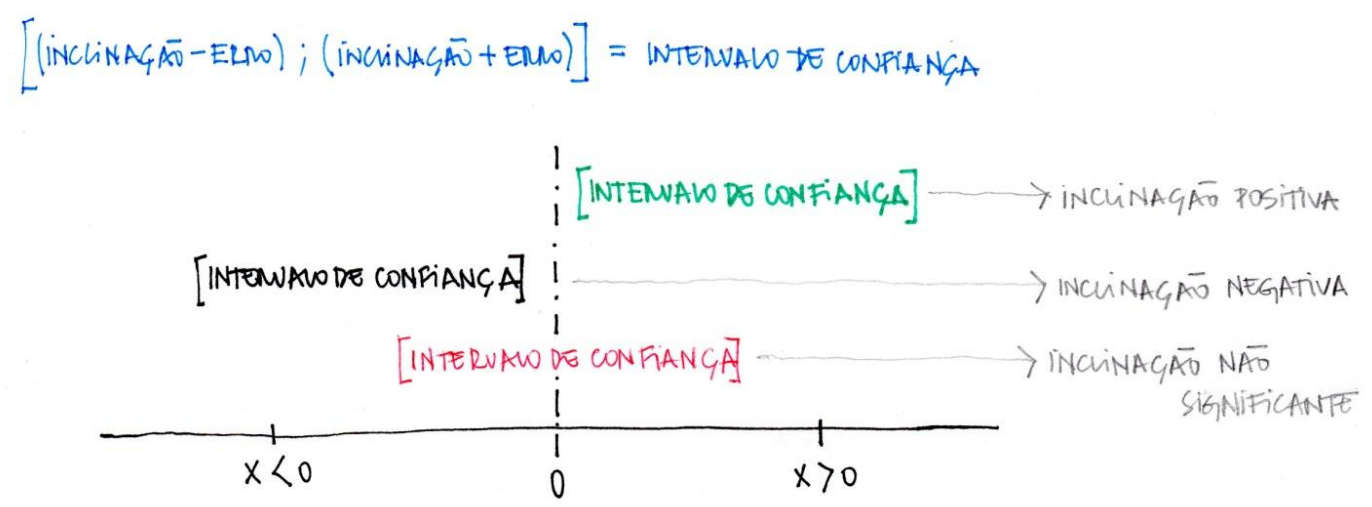

Figura 37. Análise de tendência. Diagrama explicativo: intervalo de confiança (significância estatística).

Após a análise da significância estatística da tendência de cada pixel, fez-se necessário analisar a significância prática, ou seja, se a magnitude do aumento ou da redução das variáveis era relevante $e^{34}$.

Dada a dificuldade em encontrar referências bibliográficas que tratem deste tema ${ }^{35}$, foram testados diferentes valores para a significância prática. Para a variável $T_{\text {sup }}$ foram consideradas significativas alterações superiores a $0,5^{\circ} \mathrm{C}$ e para os índices de vegetação alterações superiores a 0,05. A definição dos valores de significância prática considerou a acurácia do sensor MODIS para os produtos utilizados: 0,5K para o produto de $T_{\text {sup }}$ (WAN, 2014), 0,02 para o índice NDVI e 0,01 para o EVI (MODIS LAND TEAM, 2018 ${ }^{36}$ ). Para a definição da significância prática da vegetação foram realizadas algumas medidas pontuais dos índices em algumas cenas de EVI e NDVI em áreas com diferentes coberturas vegetais. A diferença entre os índices em áreas gramadas e áreas florestais pode ser

\footnotetext{
${ }^{34} \mathrm{O}$ cálculo referente à análise de regressão executada encontra-se no Apêndice 1.

35 ECKERT et al. (2015), utilizam o valor de 0,5 para a significância prática de uma série temporal de NDVI da Mongólia.

${ }^{36}$ A acurácia dos IVs adotada pela equipe de desenvolvimento do MODIS baseia-se em estudos de referência em diferentes biomas.
} 
pequena, conforme será abordado em um dos estudos exploratórios apresentados no Capítulo 4. Assim, a significância prática escolhida para os índices também foi pequena.

A Figura 38 ilustra a significância prática das variáveis analisadas.

\section{inclinacpés com significancia estatistica}

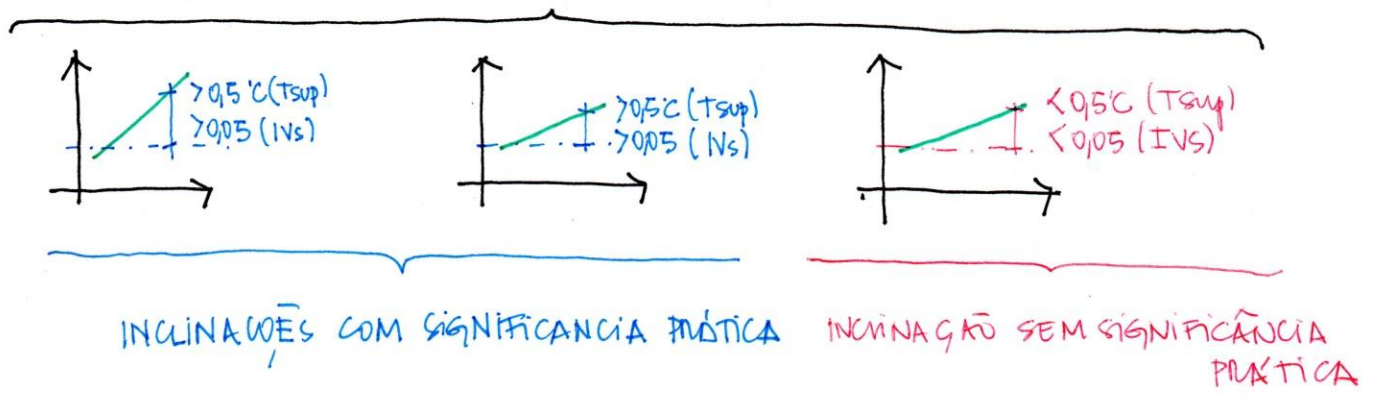

Figura 38. Análise de tendência. Diagrama explicativo: significância prática.

Conforme será abordado no Capítulo 4, a análise da tendência dos dois índices de vegetação deve ser feita de forma cautelosa, mesmo após o tratamento estatístico dos dados. A identificação de tendência positiva ou negativa nesses índices não significa necessariamente que ocorreu aumento ou supressão de vegetação, visto que a resposta de cada índice à quantidade de biomassa deve ser levada em consideração para esse tipo de conclusão.

Com o objetivo de identificar o ano no qual ocorreu a primeira alteração significativa, o mesmo procedimento de ajuste da reta de regressão linear foi realizado para diferentes intervalos temporais. Para que se pudesse ter um número suficiente de observações para caracterizar a tendência dos dados, estabeleceu-se como intervalo mínimo o período de cinco anos. Foram avaliadas as tendências dos períodos: 2003 a 2008, 2003 a 2009, e assim por diante até o período 2003 a 2017. Dessa forma foi possível identificar o primeiro ano de ocorrência de alteração significativa ${ }^{37}$.

\footnotetext{
${ }^{37}$ A identificação do primeiro ano de ocorrência de alteração significativa da variável estudada em um determinado pixel não garante que outras alterações em anos posteriores não ocorreram. Dada a grande quantidade de dados, o objetivo da análise foi verificar a partir de qual ano ocorreram alterações. Do mesmo modo, os locais identificados com alteração em 2008 podem ter sofrido alterações em qualquer ano do período 2003 a 2008.
} 


\section{Caracterização espaço-temporal da morfologia, da temperatura de superfície e da vegetação}

Este capítulo apresenta os resultados da pesquisa, elaborados a partir da aplicação do método descrito no Capítulo 3.

Todas as análises foram desenvolvidas para a Região Metropolitana de São Paulo (RMSP) ao longo de 15 anos, compreendendo da estação chuvosa de 2002/2003 à estação seca de 2017.

A RMSP foi instituída em 1973 pela Lei Complementar Federal n¹4 (BRASIL, 1973), disciplinada pela Lei Complementar Estadual n94 (SÃO PAULO, 1974) e reorganizada pela Lei Complementar n¹.139 (SÃO PAULO, 2011). Concentra 39 municípios (Figura 39), com população estimada de 21,6 milhões de pessoas (IBGE, 2018), abrangendo $7.963 \mathrm{~km}^{2}$ $(C E M, 2007)^{38}$.

Morfologicamente apresenta um núcleo urbanizado, aqui denominado genericamente por área urbana principal, que abrange diversos municípios, e área periférica ocupada por áreas urbanizadas desagregadas do núcleo urbano principal, áreas de ocupação esparsa, áreas agrícolas e áreas de proteção ambiental com densa cobertura vegetal. Aparentemente homogênea quando observada à distância, como nas imagens orbitais, a área urbanizada da RMSP apresenta heterogeneidades diversas, tanto nos aspectos formais, com tipos de ocupação e densidades variados, quanto nos aspectos sociais, com grandes diferenças de renda, escolaridade e acesso a serviços básicos como saúde e educação. A Figura 39 apresenta a divisão político-administrativa da RMSP sobreposta à área ocupada, dividida em ocupação urbana e ocupação esparsa. Esse mapa foi elaborado a partir do mapa de morfologia urbana 2017, apresentado no item 4.1.1 (Figura 45). Todas as classes construídas do mapa foram agregadas em uma única classe, denominada ocupação urbana, sendo a classe ocupação esparsa equivalente em ambos os mapas.

\footnotetext{
38 Área da RMSP calculada a partir de contornos perimétricos conforme quadro político-administrativo de 01 jan. 2001. Arquivo vetorial shapefile disponibilizado pelo CEM (2007).
} 


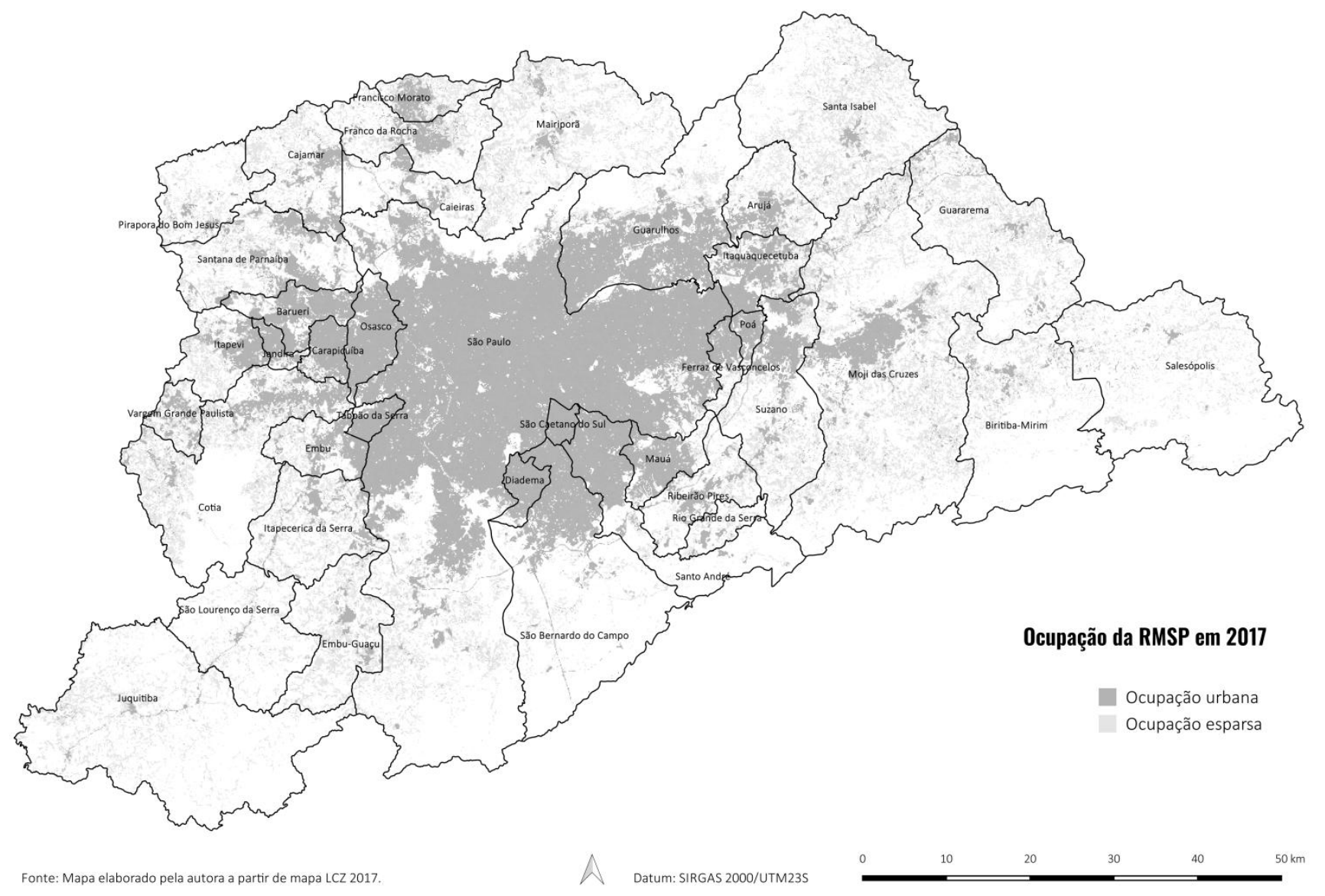

Figura 39. Divisão Político Administrativa da Região Metropolitana de São Paulo e área urbanizada. Fonte: elaboração própria. 


\subsection{Caracterização espacial}

As análises espaciais tiveram por objetivo caracterizar a RMSP, segundo as variáveis estudadas, verificando a relação entre elas. Serão apresentados os resultados de morfologia urbana para os anos de 2002, 2010 e 2017 e os resultados de temperatura superficial ( $T_{\text {sup }}$ ) e índices de vegetação de 2002 a 2017. Foram computadas as temperaturas de superfície e os índices de vegetação para cada um dos tipos morfológicos nos anos de mapeamento e testadas as correlações entre temperaturas superficiais e índices de vegetação para todos os anos de análise.

\subsubsection{Morfologia Urbana}

Foram desenvolvidos mapas de morfologia urbana, segundo local climate zones (LCZ), para os anos de 2002, 2010 e 2017 de acordo com a metodologia descrita no item 3.2 deste trabalho, com resoluções espaciais de $100 \mathrm{~m}$ e $250 \mathrm{~m}$. Os mapas com resolução de 100m foram utilizados para a caracterização espacial da morfologia urbana e para a verificação de alterações morfológicas entre os anos analisados: 2002 a 2010, 2010 a 2017 e 2002 a 2017, apresentadas no item 4.2.1. Os mapas de 250m de resolução espacial foram utilizados para as análises combinadas com a $\mathrm{T}_{\text {sup }}$ e com os índices de vegetação.

A Figura 40 apresenta o mapa de morfologia urbana de 2002. A comparação visual com imagens IKONOS 2002 (IG, 2002) evidenciou boa correspondência para as principais morfologias; porém, como mencionado no Capítulo 3, algumas incertezas na classificação foram verificadas. 


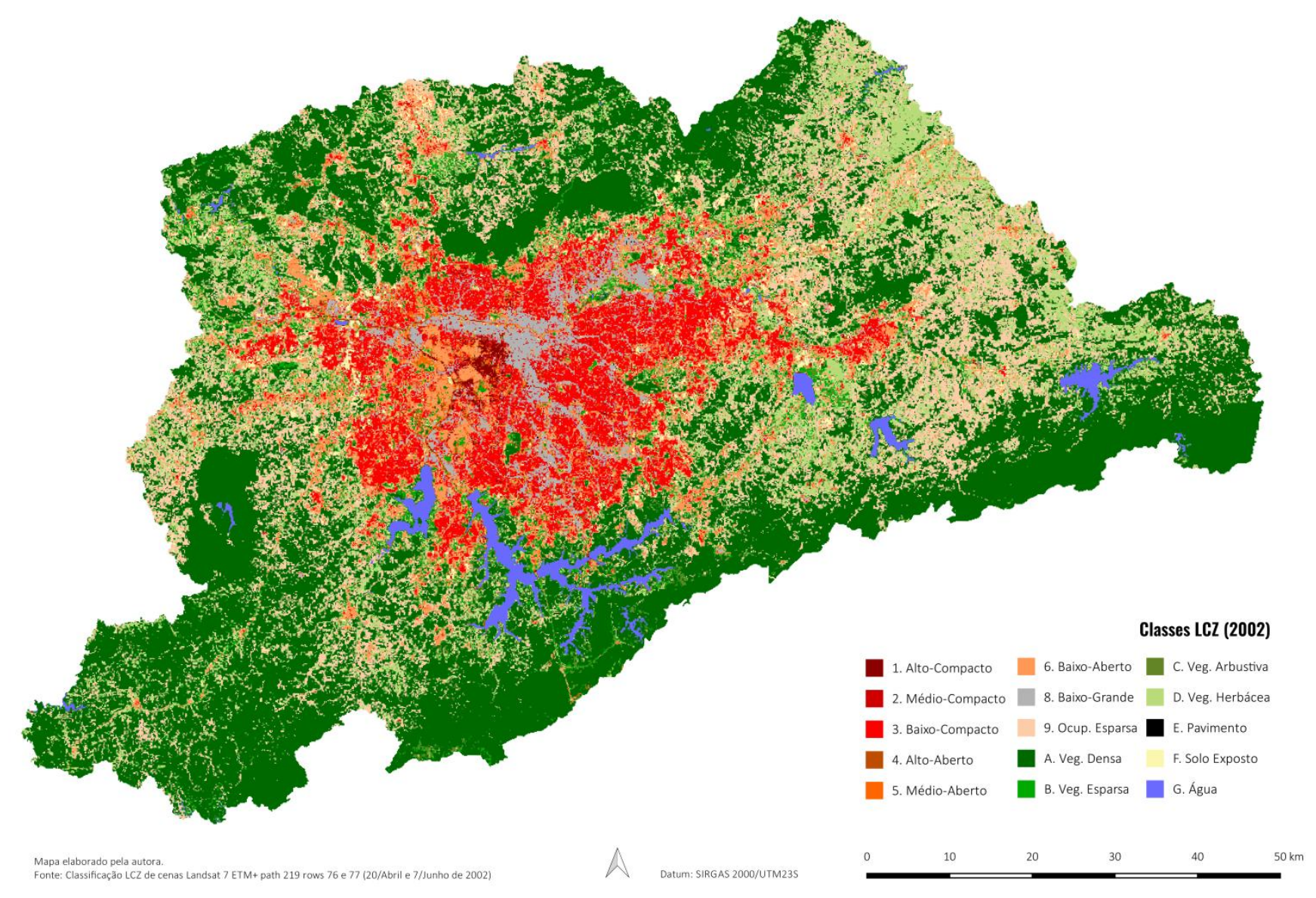

Figura 40. Mapa com a classificação LCZ de 2002. Resolução espacial: 100m. Fonte: elaboração própria.

A principal incerteza, que ocorre nos mapas dos três anos de análise, é a classificação incorreta dos Rios Tietê e Pinheiros, que são classificados como LCZ 1 (Alto-Compacto). Mesmo com a alteração das áreas de treinamento o problema persistiu. Ferreira et al. (2016) discutem esse erro, sugerindo que a quantidade de pavimentos nas margens dos rios, bem como os altos níveis de poluição poderiam ser a causa dos erros de classificação $^{39}$. A correção manual dessas áreas foi considerada, porém, dadas as dimensões do pixel (100m), ora este deveria ser alterado para a classe Água (LCZ G), ora para a classe Pavimento (LCZ E), a depender do percentual de participação da água na área do pixel. Esse processo teria que ser feito visualmente, o que demandaria elevado tempo de processamento. Além disso, o maior impacto desse erro de classificação seria

\footnotetext{
39 Durante workshop promovido pelo WUDAPT, intitulado 'Various Applications of WUDAPT products' realizado na Chinese University of Hong Kong em 2016 esse erro foi amplamente discutido com os desenvolvedores e demais pesquisadores participantes do encontro. Pesquisadores da China e da Índia relataram problemas semelhantes em corpos d'água com altos níveis de poluição. A recomendação dos desenvolvedores do WUDAPT foi a edição manual dessas áreas.
} 
na aferição da $T_{\text {sup }}$ por classe LCZ; porém, como os principais corpos d'água foram excluídos da análise, as áreas de rios classificados como edifícios não seriam computadas, assim, optou-se pela não edição dessas áreas.

A aproximação do mapa para a área do entroncamento da Rodovia Castello Branco com o Rodoanel Mario Covas (trecho Oeste, que se encontrava em obras em $2002^{40}$ ), evidencia tanto a boa correspondência para as principais características morfológicas na escala local (Figura 41), quanto algumas das principais confusões verificadas em todas as classificações LCZ: A) a classificação do Rio Tietê como LCZ 1 (Alto-compacto) e B) a classificação de áreas densamente ocupadas por edifícios baixos (LCZ 3) como áreas de grandes edifícios baixos (LCZ 8).
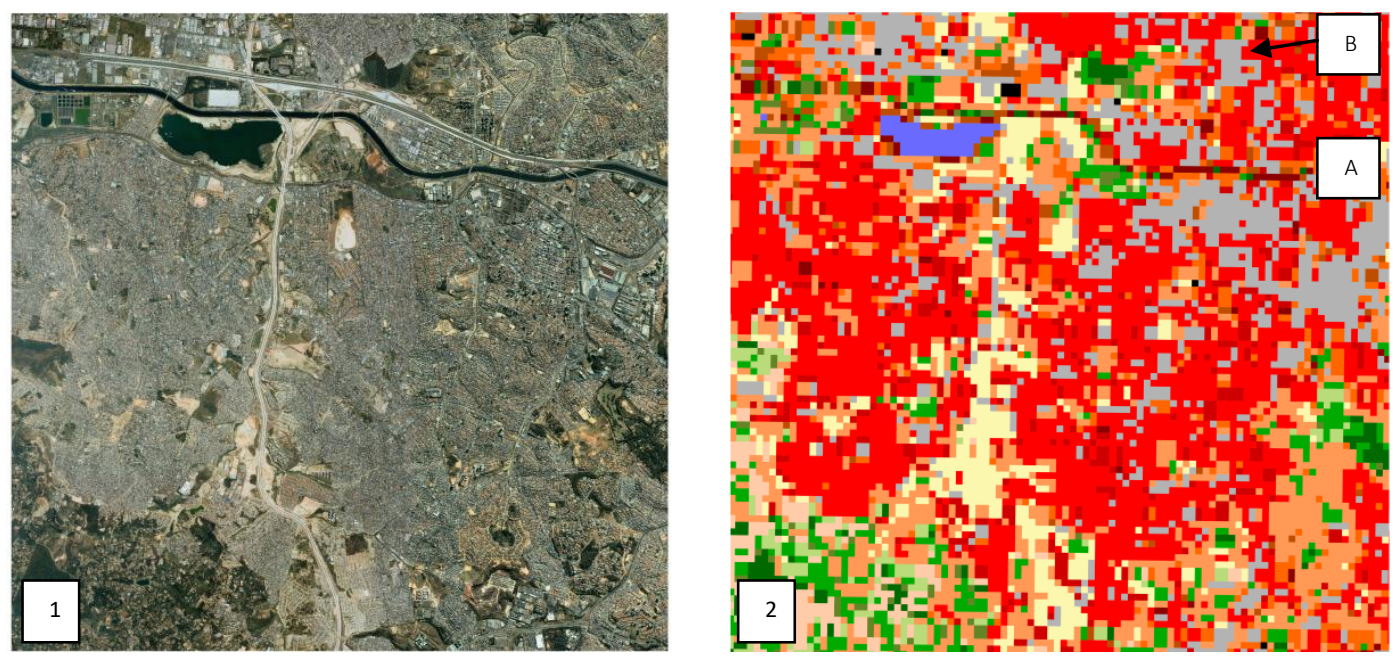

Figura 41. Rodovia Castello Branco e trecho Oeste do Rodoanel Mario Covas em obras. 1) Imagem IKONOS (2002). 2) Mapa LCZ (2002). Fonte: 1) IG (2002), 2) Elaboração própria.

\footnotetext{
${ }^{40}$ O trecho Oeste do Rodoanel Mario Covas foi inaugurado em Outubro de 2002 (DERSA, 2019).
} 
A Figura 42 apresenta o mapa de 2010. A comparação visual com as ortofotos 2010/2011

(EMPLASA, 2010) evidenciou boa correspondência para as principais morfologias urbanas.

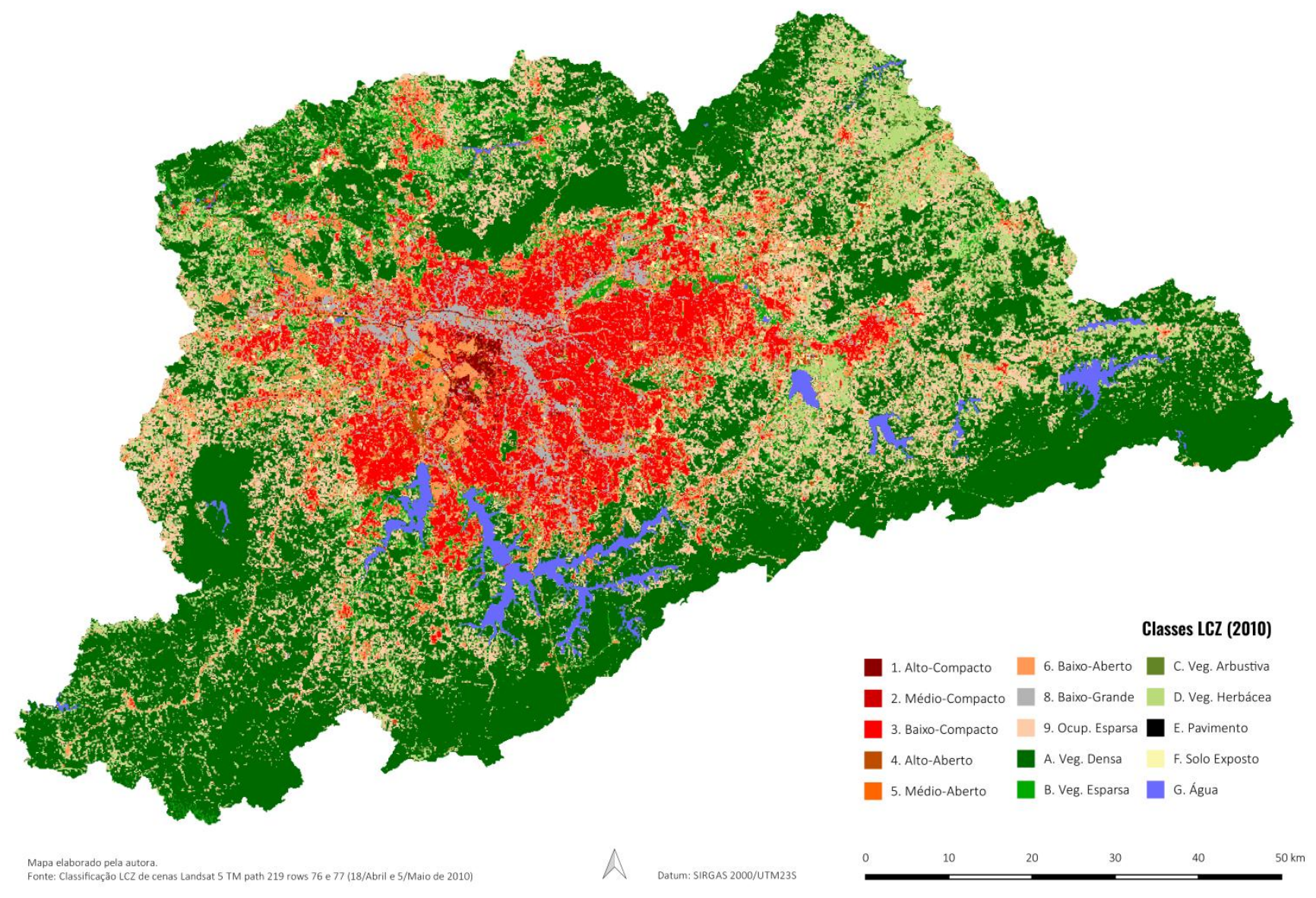

Figura 42. Mapa com a classificação LCZ de 2010. Resolução espacial: 100m. Fonte: elaboração própria.

Assim como no mapa de 2002, os rios Tietê e Pinheiros foram classificados como LCZ 1 (Alto-compacto) e a aproximação para a escala local evidenciou tanto a boa correspondência com as principais características morfológicas quanto algumas imncertezas. Além das que já foram mencionadas no mapa de 2002, verifica-se a classificação de alguns eixos viários como LCZ 8 (Grande-compacto). A Figura 43 exemplifica, para a região da Marginal Pinheiros, a boa correspondência da classificação para o bairro horizontal e vertical dos Jardins (divisão marcada pela Rua Estados Unidos e claramente identificada na Figura 43.2, área A, e a classificação do trecho inicial da Av. Francisco Morato como LCZ 8 (Figura 43.2, área 2.B). A grande quantidade de áreas 
pavimentadas existentes nas zonas do tipo 8 possivelmente explica a classificação equivocada de algumas grandes avenidas.
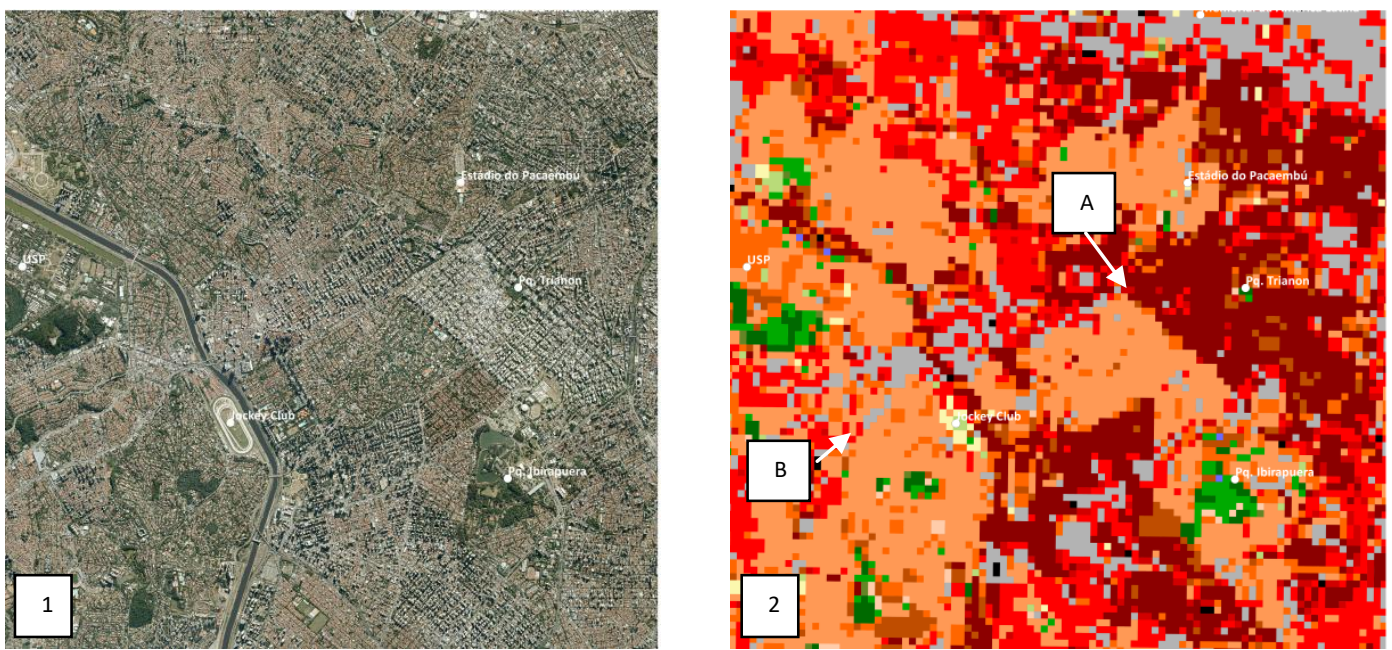

Figura 43. 1) Imagem Ortorretificada (2010/2011). 2) Mapa LCZ (2010). Marginal Pinheiros e bairros da zona oeste de São Paulo. Fonte: 1) EMPLASA (2010). 2) Elaboração própria.

Nas áreas menos urbanizadas, como a região de Salesópolis (Figura 44), áreas homogêneas apresentam boa classificação. Em áreas heterogêneas podem ser verificadas algumas confusões entre áreas de vegetação herbácea e arbustiva. Áreas de vegetação arbórea densa podem ser confundidas com áreas de ocupação esparsa, uma vez que estas podem apresentar extensa cobertura arbórea e, na escala da classificação, serem confundidas com áreas de vegetação densa.
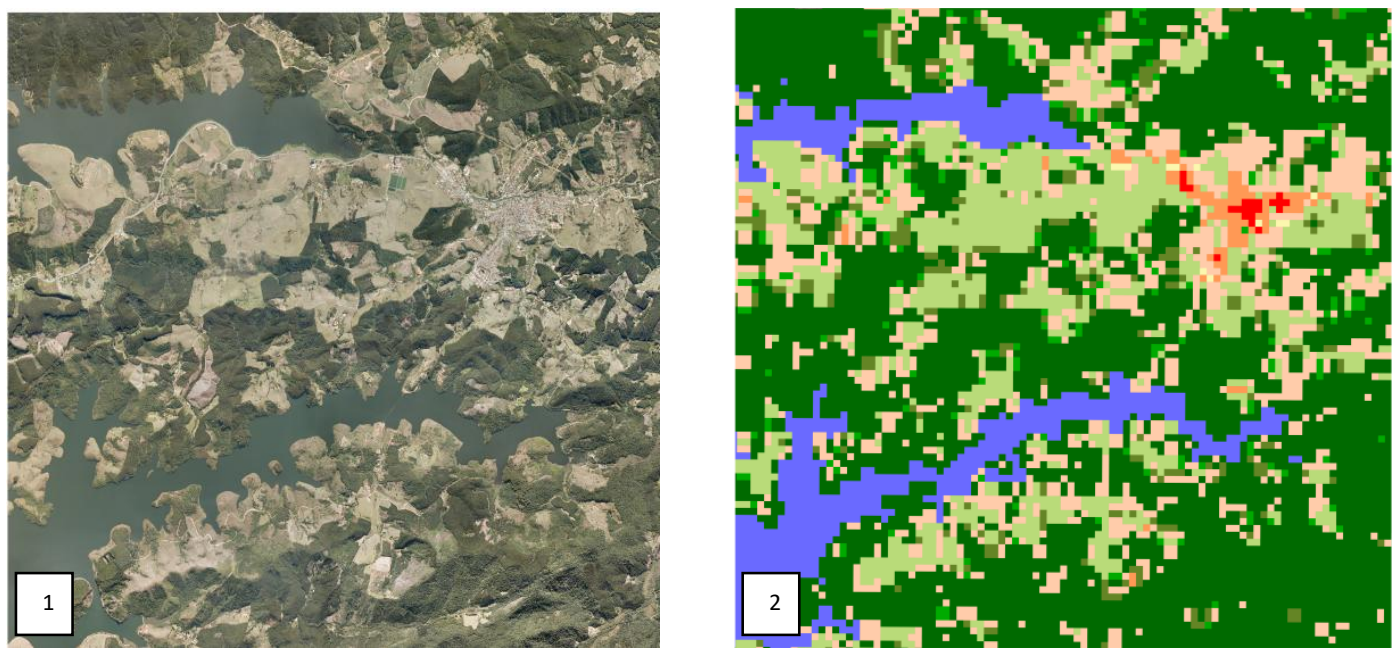

Figura 44. 1) Imagem Ortorretificada (2010/2011). 2) Mapa LCZ (2010). Salesópolis. Fonte: 1) EMPLASA, (2010). 2) Elaboração própria. 
Por fim, o mapa de 2017 (Figura 45) é o que melhor representa as áreas pavimentadas e os rios Tietê e Pinheiros que, nessa classificação, apresentam trechos corretamente classificados como água. Tal diferença em relação aos mapas anteriores possivelmente deve-se a melhoramentos do satélite Landsat 8 OLI-TIRS em relação aos seus antecessores.

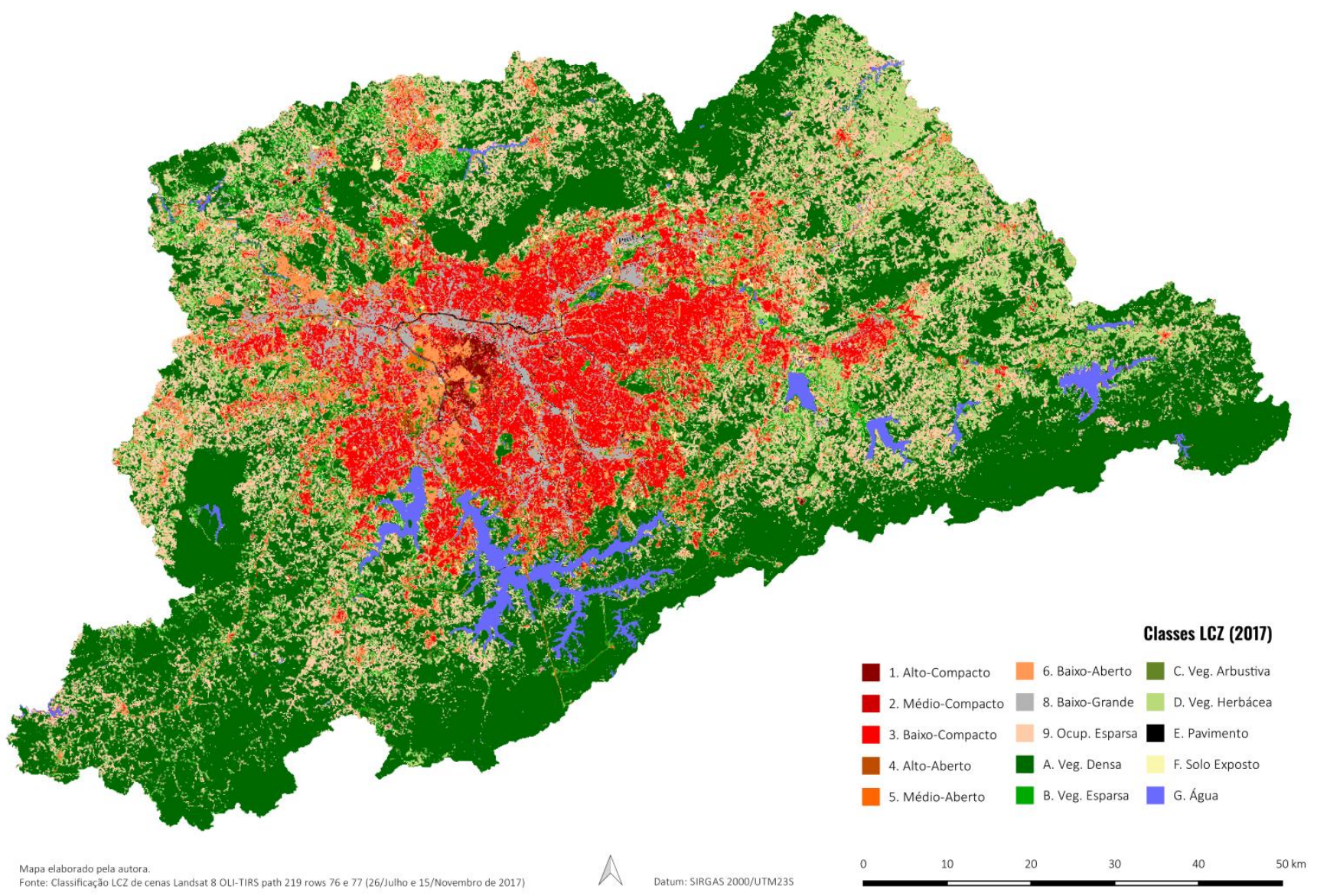

Figura 45. Mapa com a classificação LCZ de 2017. Resolução espacial: 100m. Fonte: elaboração própria.

A Figura 46 mostra trechos das Marginais Pinheiros e Tietê nos quais se verifica a melhora na classificação em relação às versões anteriores dos mapas LCZ. 

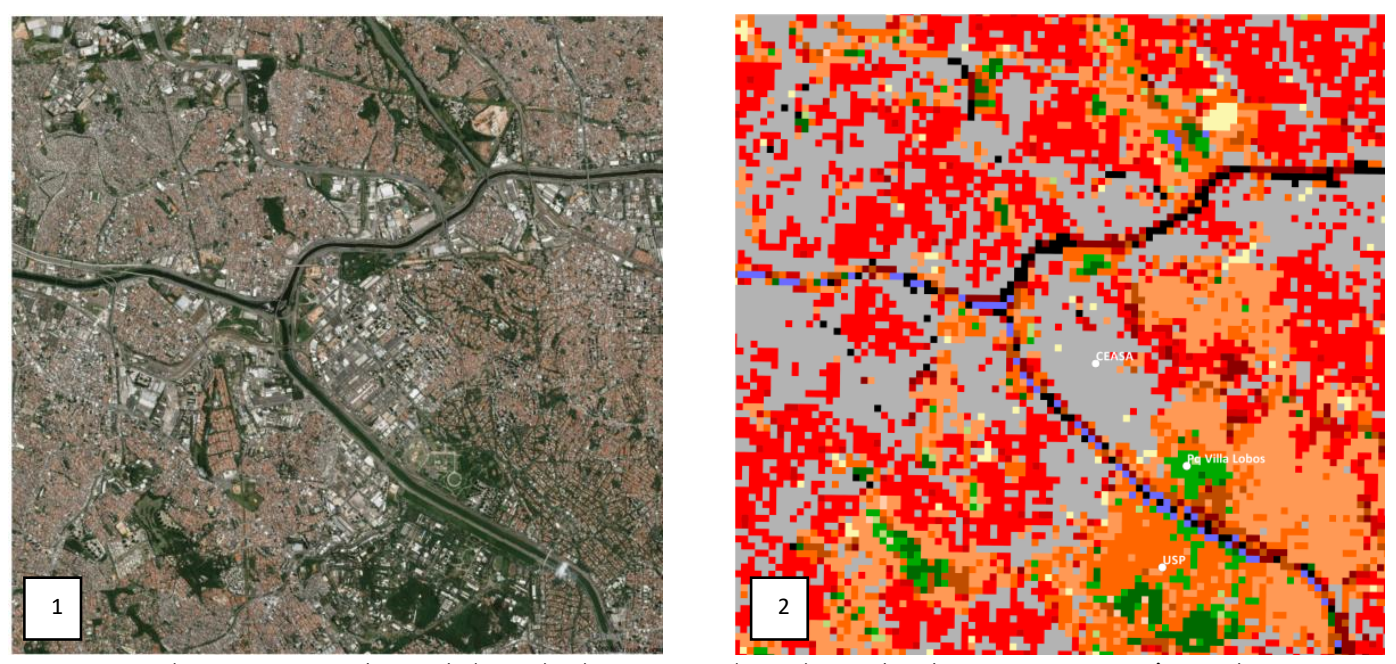

Figura 46. 1) Imagem Google Earth (2017). 2) Mapa LCZ (2017). Trecho das Marginais Tietê e Pinheiros. Fonte:

1) Google (2018). 2) Elaboração própria.

\subsubsection{Temperatura de superfície}

Foram elaboradas imagens médias das temperaturas superficiais noturnas e diurnas para as estações secas e chuvosas para todos os anos de análise, utilizando-se imagens com resolução espacial de $1 \mathrm{~km}$ e de $250 \mathrm{~m}$ e considerando-se todas as imagens e apenas aquelas com mais de $50 \%$ de dados válidos.

A correlação entre a temperatura e os índices de vegetação, discutida no item 4.1.4, foi a mesma, utilizando-se as médias com a totalidade das informações ou com mais de $50 \%$ de dados válidos. Já a correlação dos dados com $1 \mathrm{~km}$ de resolução espacial foi ligeiramente superior à correlação entre os dados com $250 \mathrm{~m}$ de resolução. Assim, optou-se por apresentar nesse item os resultados na resolução espacial original de $1 \mathrm{~km}$, com imagens médias que utilizaram dados com mais de $50 \%$ de pixels válidos.

$A T_{\text {sup }}$ diurna apresentou variação entre $22^{\circ} \mathrm{C}$ e $43^{\circ} \mathrm{C}$ nas estações chuvosas (Figura 47) e entre $18^{\circ} \mathrm{C}$ e $34^{\circ} \mathrm{C}$ nas estações secas (Figura 48). Já as temperaturas superficiais noturnas apresentaram variação entre $12^{\circ} \mathrm{C}$ e $22^{\circ} \mathrm{C}$ nas estações chuvosas (Figura 53) e entre $9^{\circ} \mathrm{C}$ e $19^{\circ} \mathrm{C}$ nas estações secas (Figura 54). Foi atribuída a mesma escala cromática para todos os anos de uma mesma variável e estação para melhor comparação entre as imagens. 
Temperatura superficial diurna
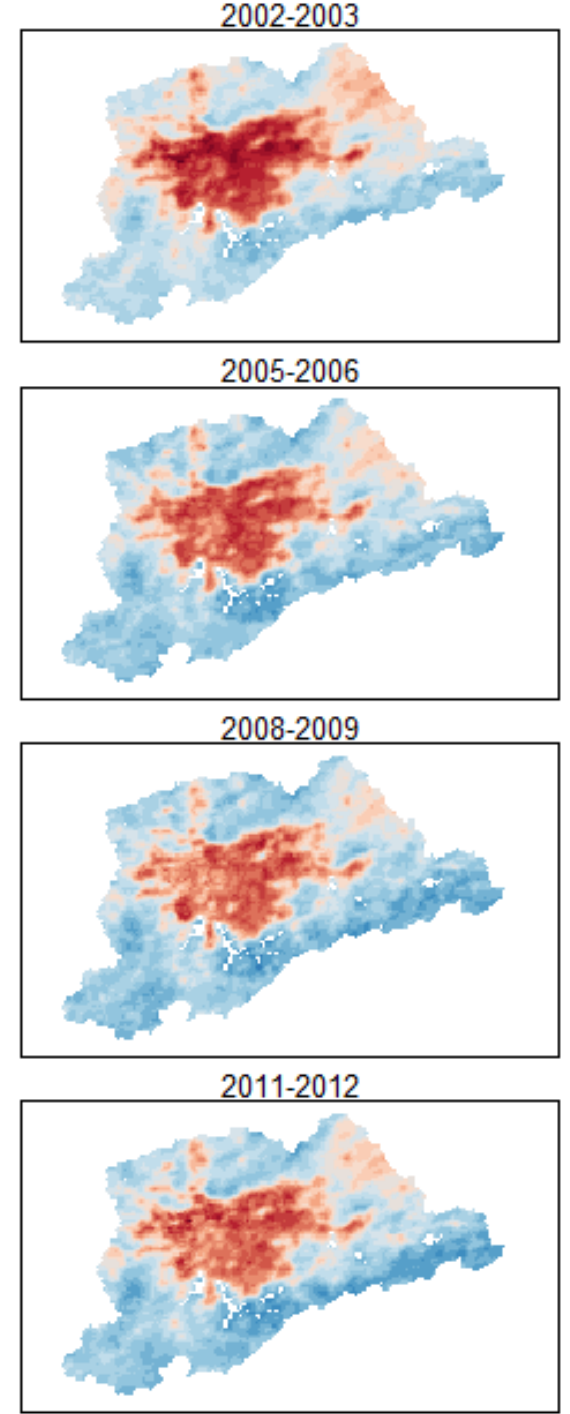

2014-2015
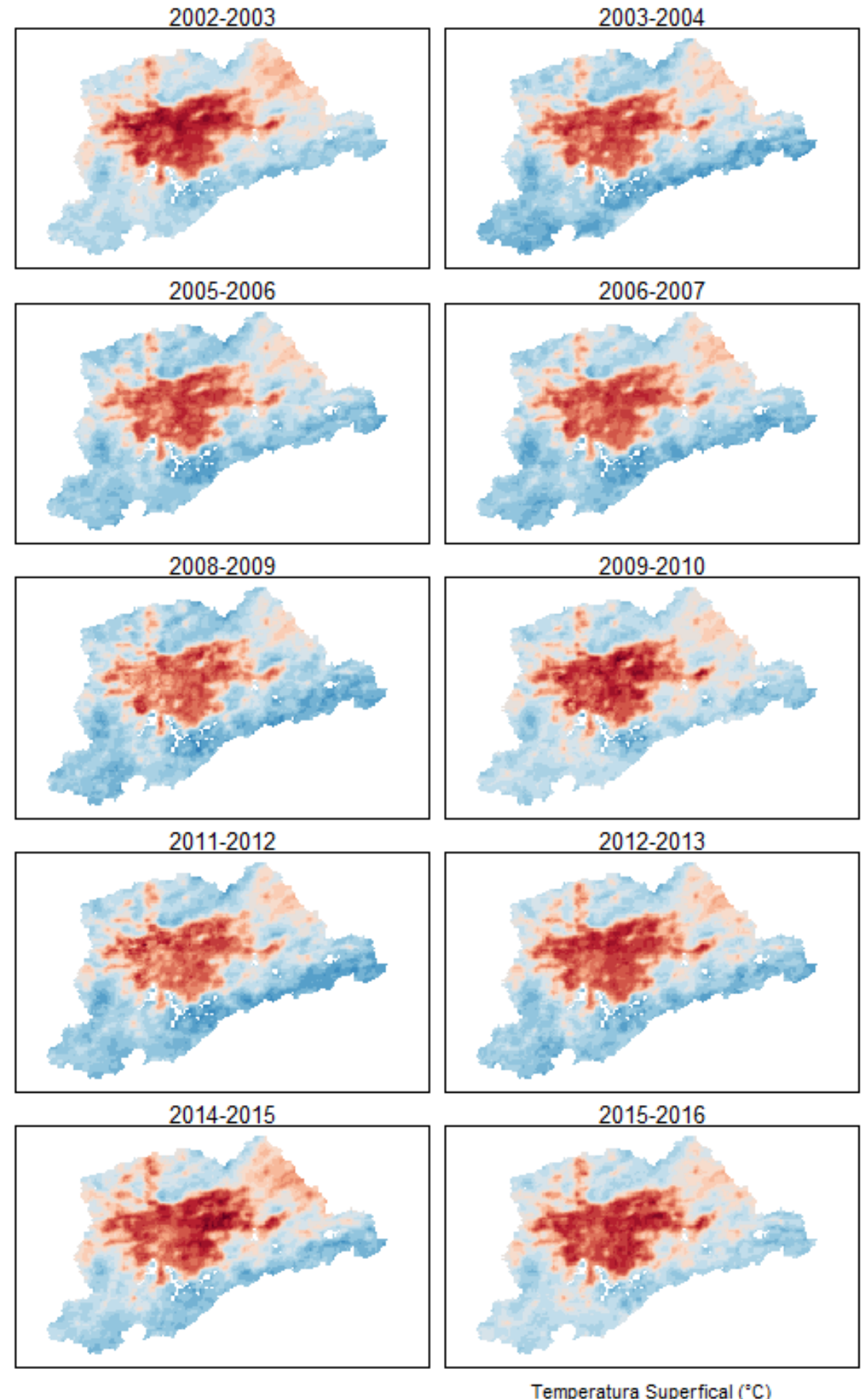

Temperatura Superfical ( ${ }^{\circ} \mathrm{C}$ )

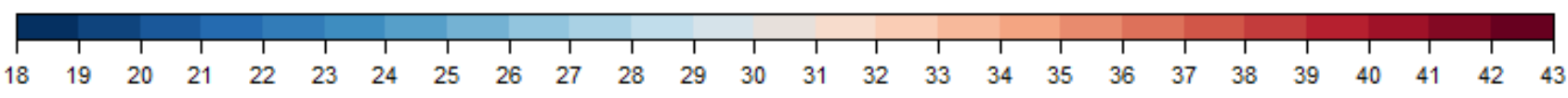

Figura 47. $T_{\text {sup }}$ diurna das estações chuvosas. 

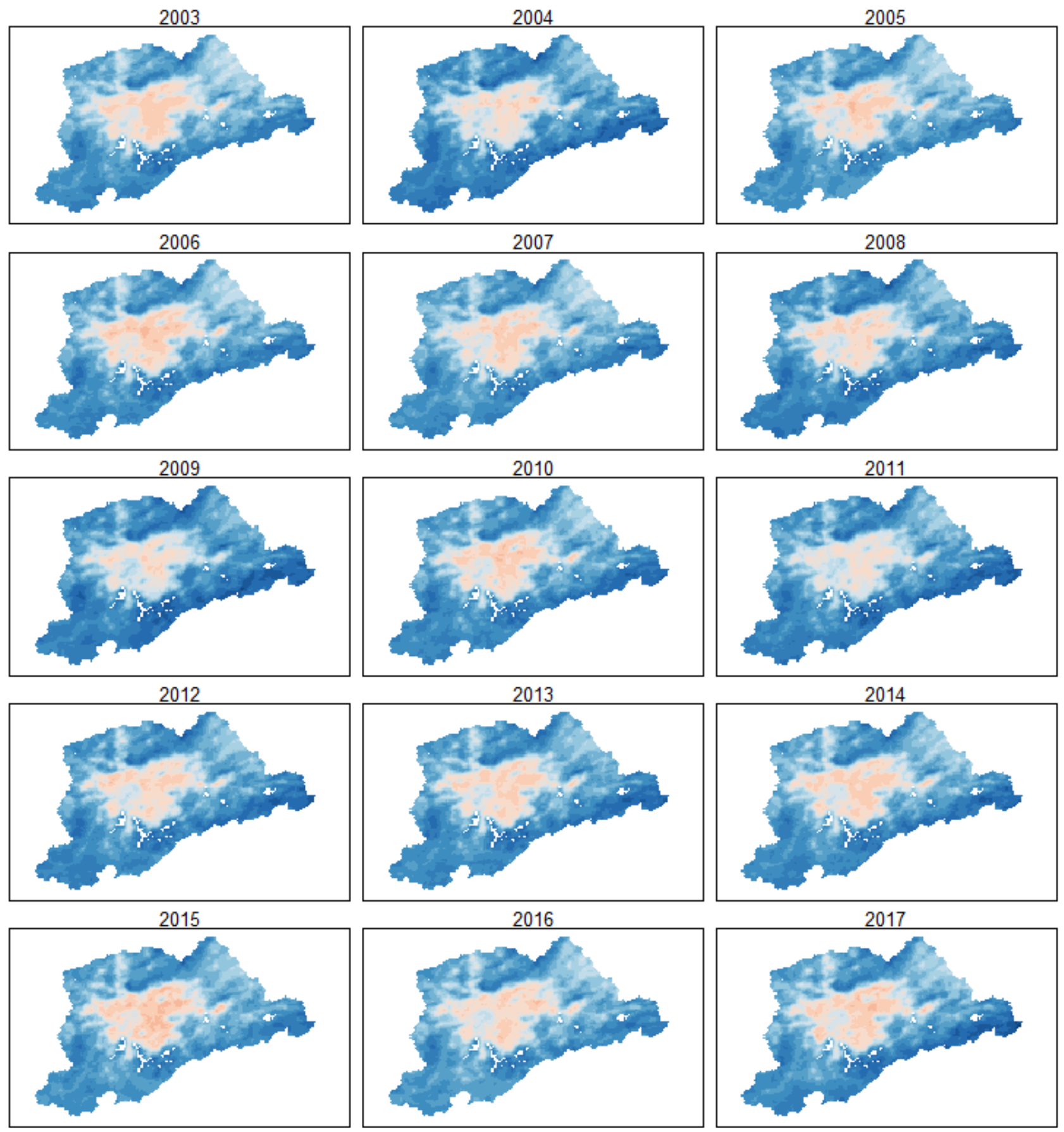

Temperatura Superfical ( $\left.{ }^{\circ} \mathrm{C}\right)$

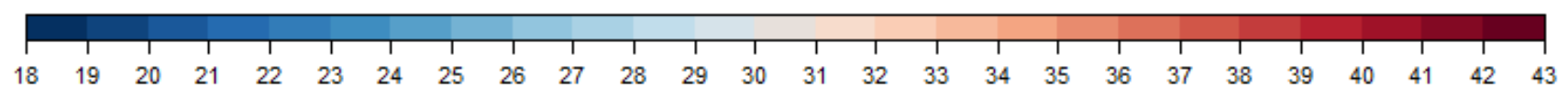

Figura 48. $T_{\text {sup }}$ diurna das estações secas. 
As diferenças entre os padrões de temperatura nas diversas estações chuvosas ao longo do período analisado podem ser consequência do menor número de amostras válidas usadas para produzir as imagens médias. É possível verificar que na estação seca, quando existe maior disponibilidade de dados, o padrão da temperatura apresenta menor variabilidade espacial, conforme pode ser verificado na Figura 48.

A área urbana apresenta $T_{\text {sup }}$ diurna superior ao seu entorno menos urbanizado e mais arborizado em todas as estações secas e chuvosas, corroborando resultados anteriormente verificados por outros pesquisadores para a cidade de São Paulo (FUCKNER; MORAES; FLORENZANO, 2009), para a RMSP (LOMBARDO, 1985) e para outras cidades (ALAVIPANAH et al., 2015; FUCKNER; MORAES; FLORENZANO, 2009; IMHOFF et al., 2010; LOMBARDO, 1985; ROTH; OKE; EMERY, 1989; SOUSA; FERREIRA, 2012). Porém, apesar de mais aquecida, a área urbanizada não apresenta temperatura homogênea, sugerindo a necessidade de distinção dos tipos morfológicos dessas áreas.

As áreas menos aquecidas no interior da área urbana, ou contiguas a ela, destacam-se claramente em todas as imagens diurnas e coincidem com áreas densamente arborizadas e protegidas. Assim, os grandes parques da RMSP como o Parque Ecológico do Tietê e o Parque do Carmo, na Zona Leste, o Parque da Cantareira e o Pico do Jaraguá na Zona Norte, o Parque Fontes do Ipiranga na Zona Sul e a Reserva Estadual do Morro Grande, em Cotia, podem ser facilmente identificados na imagem termal. Como exemplo, a Figura 49, apresenta os parques mencionados sobre imagem média da estação seca de 2017.

Em relação à área urbana principal, destacam-se algumas áreas edificadas que apresentam $\mathrm{T}_{\text {sup }}$ diurna marcadamente inferior a seu entorno, tanto nas estações chuvosas quanto nas secas: Vila Andrade, Morumbi e Chácara Flora, na Zona Sul de São Paulo, Jardins, Alto de Pinheiros, Pacaembu e Cidade Universitária na Zona Oeste de São Paulo. Estes bairros também se encontram marcados Figura 49. 


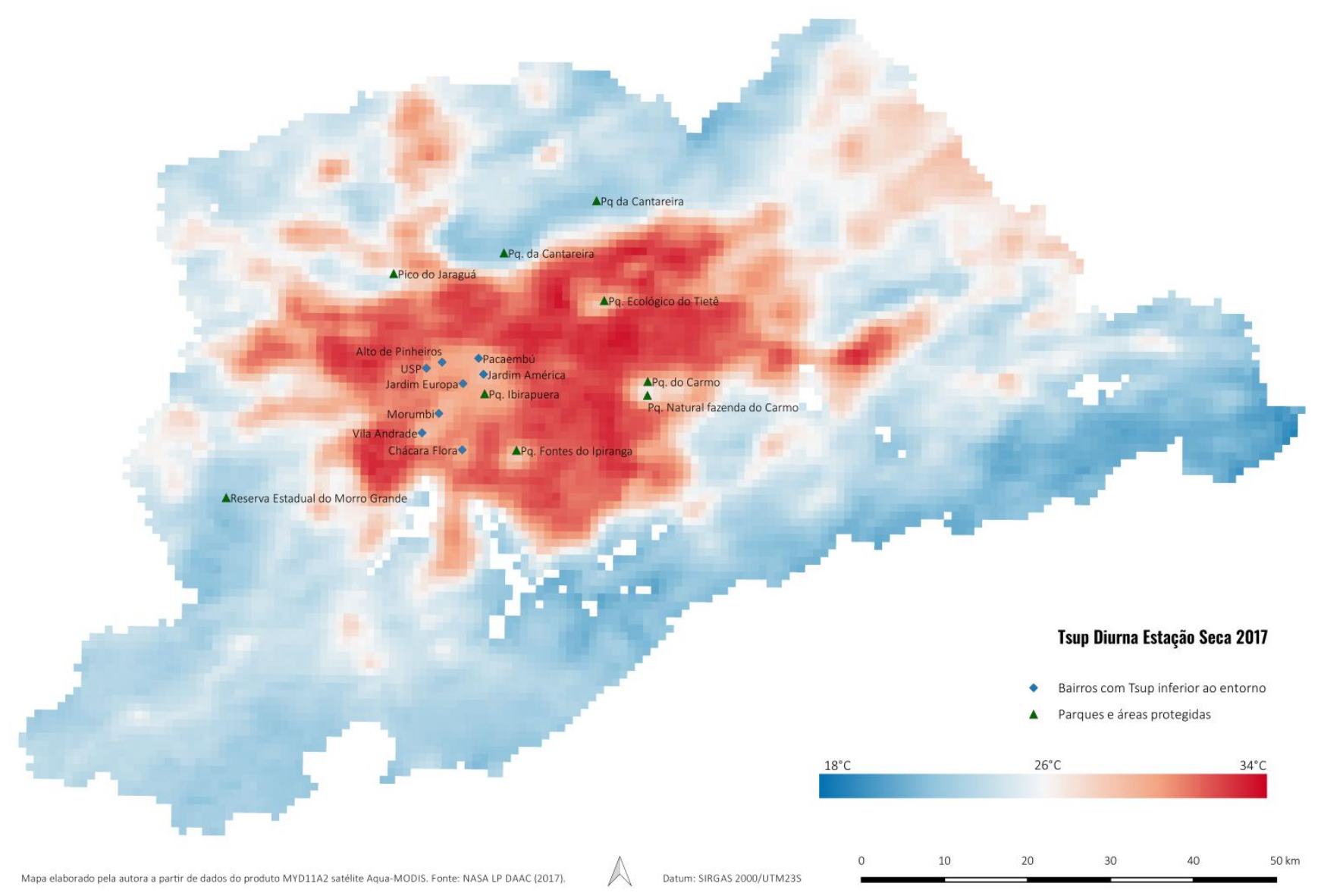

Figura 49. Áreas urbanizadas com $T_{\text {sup }}$ diurna inferior ao entorno. Estação Seca 2017.

Com o objetivo de explorar as diferenças de temperatura, sobretudo nas áreas mais urbanizadas, a temperatura média de cada pixel foi subtraída da temperatura média da RMSP, verificando-se assim quais pixels apresentam temperatura acima e abaixo da média. A Figura 50 e a Figura 51 apresentam as diferenças de temperatura em relação à média para as estações chuvosas e secas, respectivamente. 

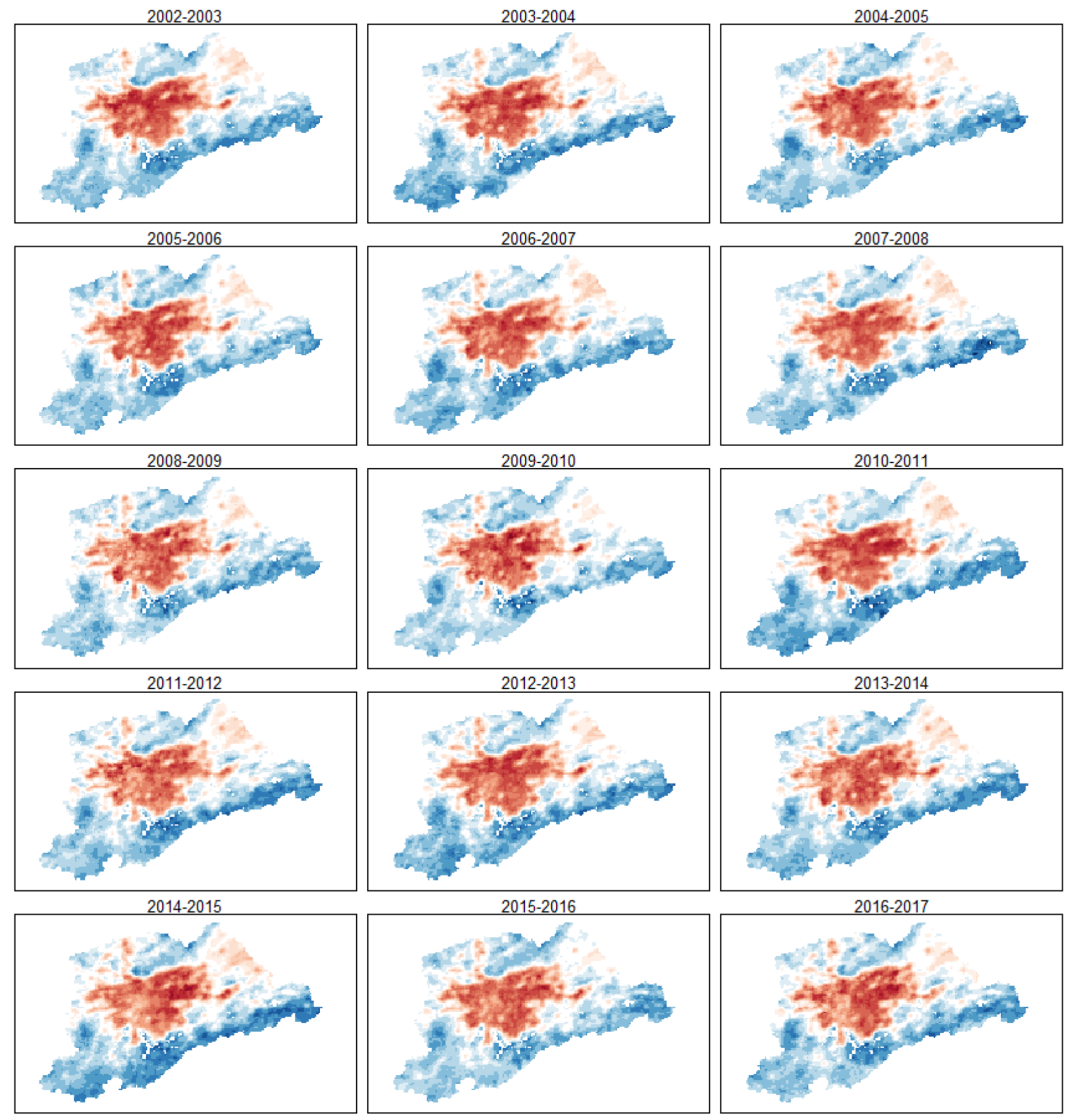

Temperatura Superfical $\left({ }^{\circ} \mathrm{C}\right)$

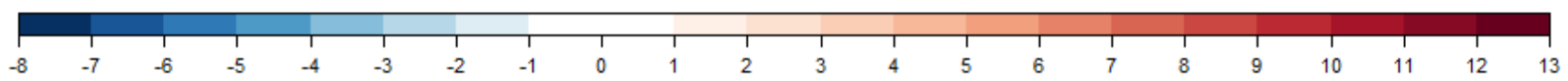

Figura 50. Diferença da $T_{\text {sup }}$ diurna de cada pixel em relação à temperatura média da RMSP. Estação chuvosa. 

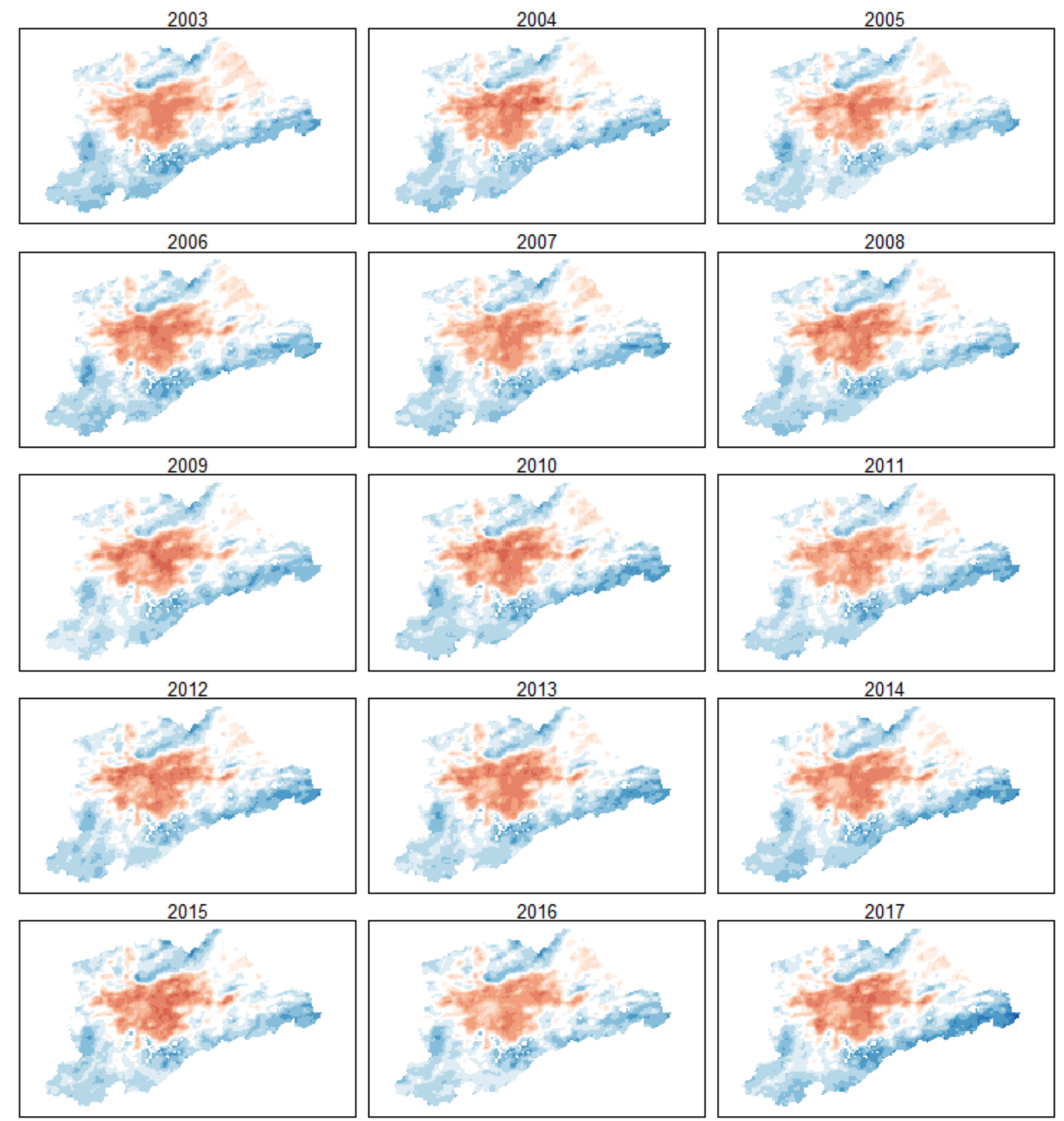

Temperatura Superfical $\left({ }^{\circ} \mathrm{C}\right)$

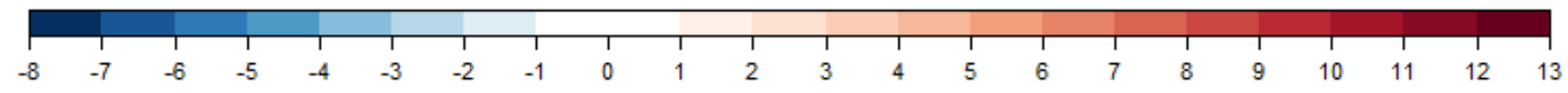

Figura 51. Diferença da $T_{\text {sup }}$ diurna de cada pixel em relação à temperatura média da RMSP. Estação Seca.

As diferenças de temperatura são maiores nas estações chuvosas, como verificado por Imhoff et al. (2010), Roth, Oke e Emery (1989) e Sidiqui, Huete e Devadas (2016). 
Apesar de menos intensas, as diferenças de temperatura em todas as estações secas delineiam claramente uma área no centro-sul da área urbana principal. Esta área corresponde aos já mencionados bairros da região sudoeste da cidade de São Paulo, que apresentam morfologia predominante das classes LCZ1 (Alto-Compacto), LCZ4 (AltoAberto) e LCZ 6 (Baixo-Aberto). A Figura 52 apresenta uma sobreposição da imagem de diferença de temperatura em relação à média da estação seca de 2017 e o mapa de LCZ de 2017, já apresentado na Figura 45.

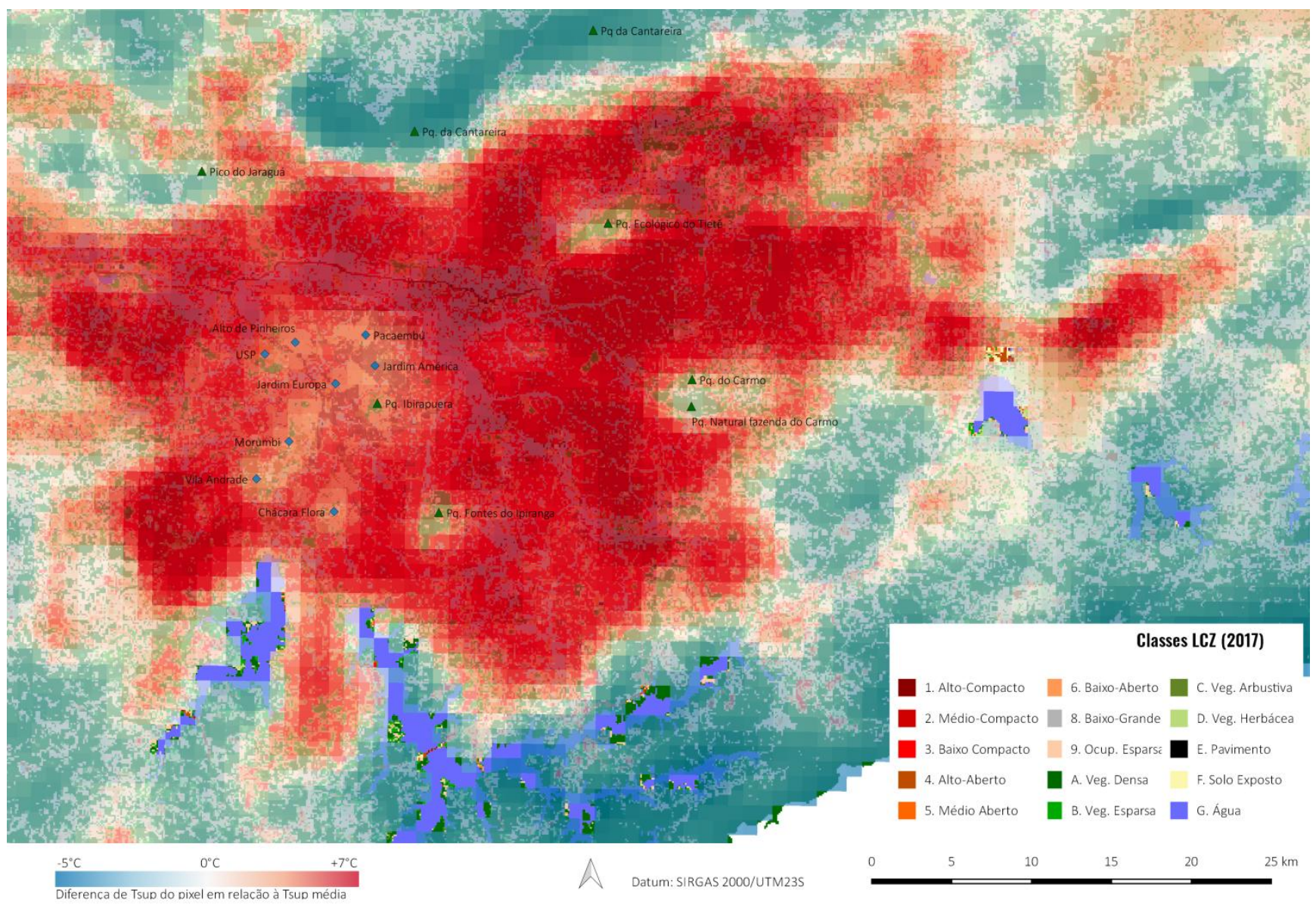

Figura 52. Sobreposição da imagem de diferença da $T_{\text {sup }}$ diurna de cada pixel em relação à temperatura média da RMSP na Estação Seca 2017 com o mapa LCZ 2017. 


\section{Temperatura superficial noturna}
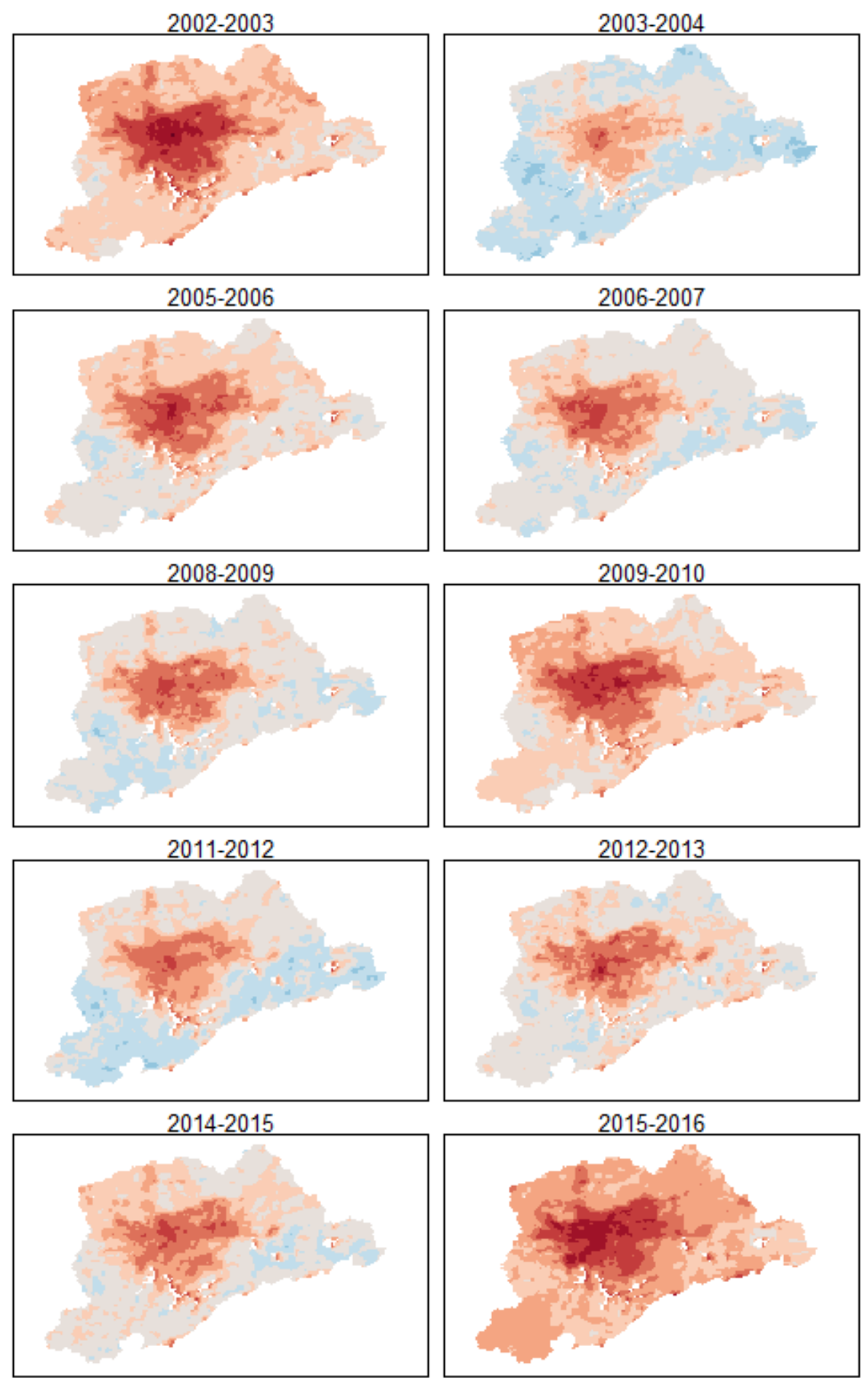

Temperatura Superfical $\left({ }^{\circ} \mathrm{C}\right)$

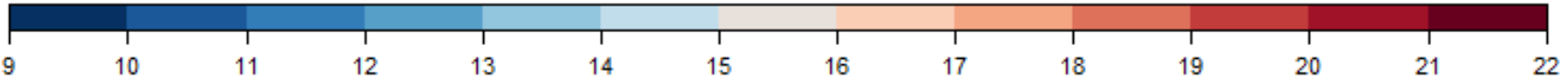

Figura 53. $T_{\text {sup }}$ noturna das estações chuvosas.
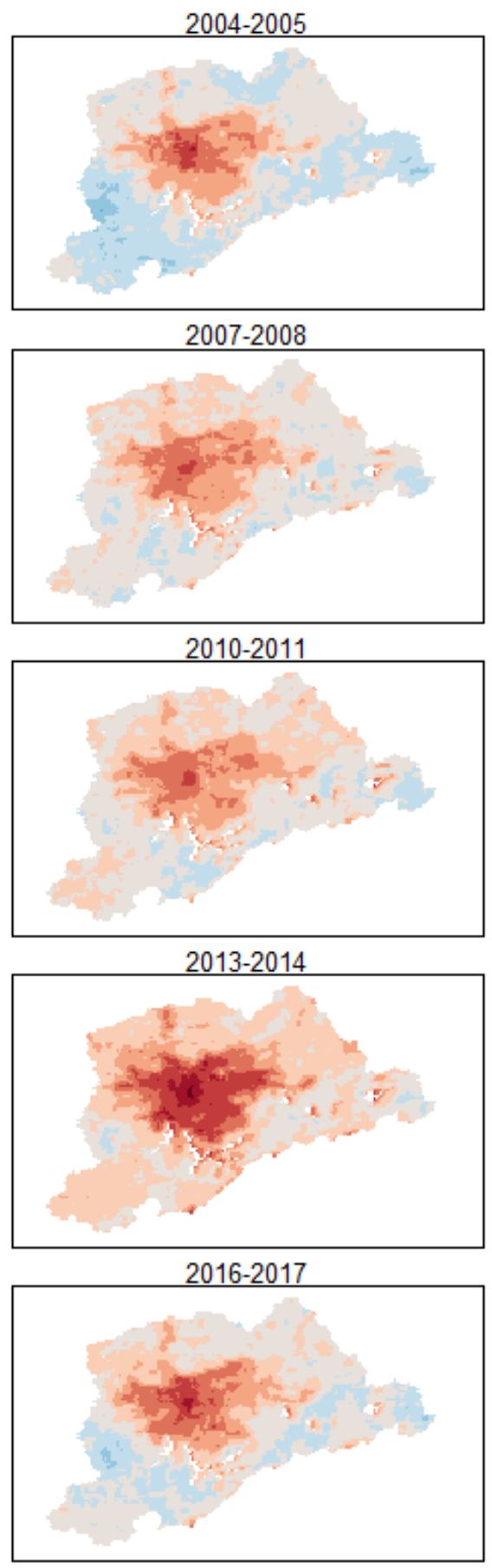

21 

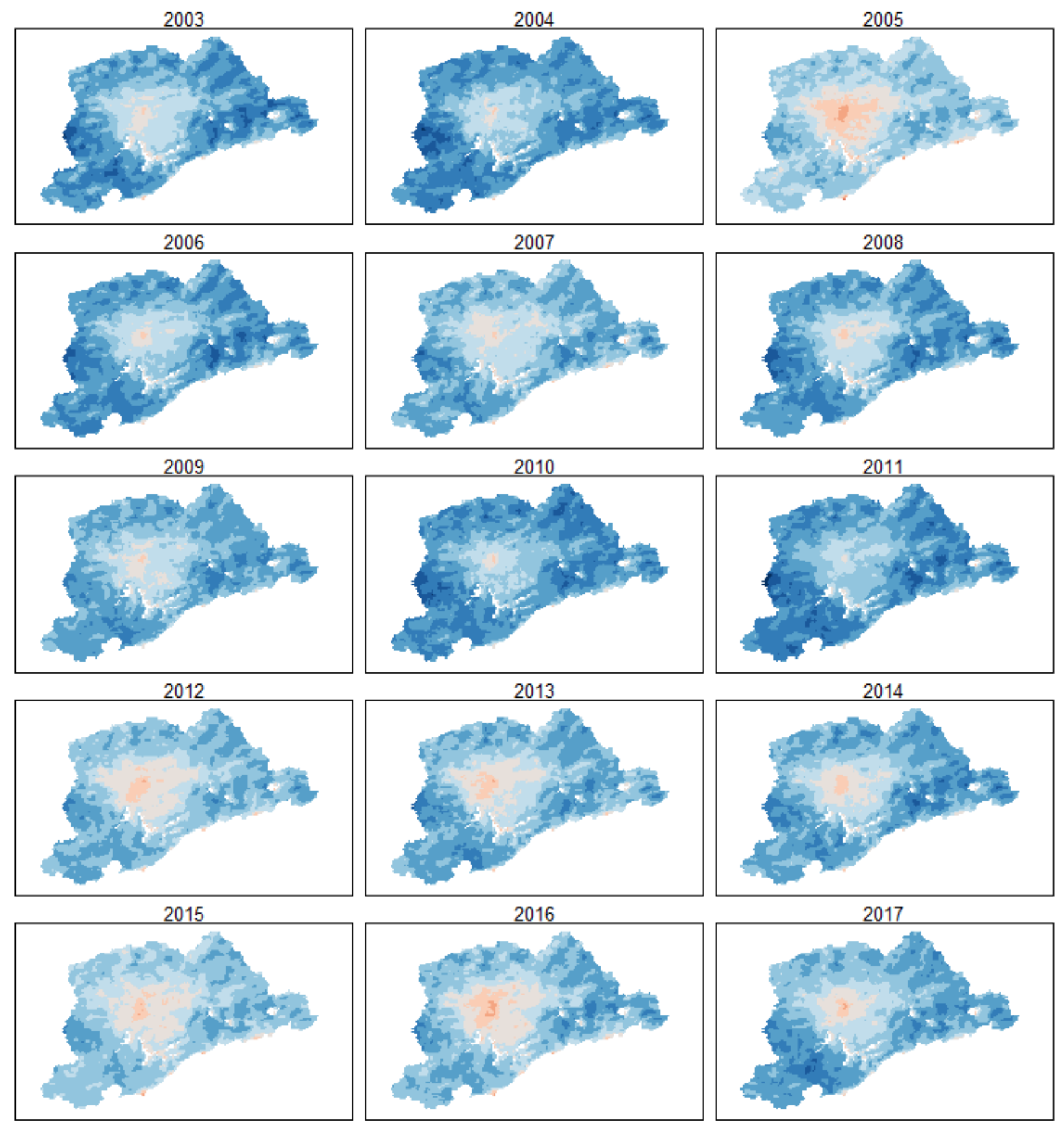

Temperatura Superfical $\left({ }^{\circ} \mathrm{C}\right)$

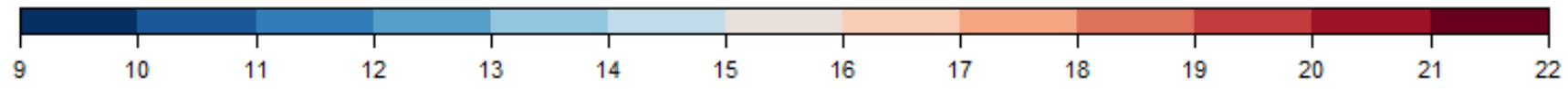

Figura 54. $T_{\text {sup }}$ noturna das estações secas. 
Assim como nas imagens diurnas, a área urbana apresenta temperatura noturna superior ao seu entorno menos urbanizado, em todas as estações chuvosas (Figura 53) e secas (Figura 54); porém, a área mais aquecida nas imagens noturnas é menos extensa do que nas imagens diurnas. Essas áreas coincidem com as áreas verticalizadas e com pouca vegetação, representadas pela tipologia da LCZ 1 (Alto-Compacto), como pode ser visto na Figura 55. Destaca-se que tais áreas apresentavam $\mathrm{T}_{\text {sup }}$ diurna inferior às áreas urbanas periféricas, compostas prioritariamente pela tipologia LCZ 3 (Baixo-compacto). As áreas mais aquecidas próximas a corpos d'água possivelmente indicam que a máscara criada para evitar que pixels com água fossem computados não mascarou algumas áreas próximas à margem, ou que esses pixels possuem vegetação sobre água, que não foram detectadas durante a criação do polígono de mascaramento.

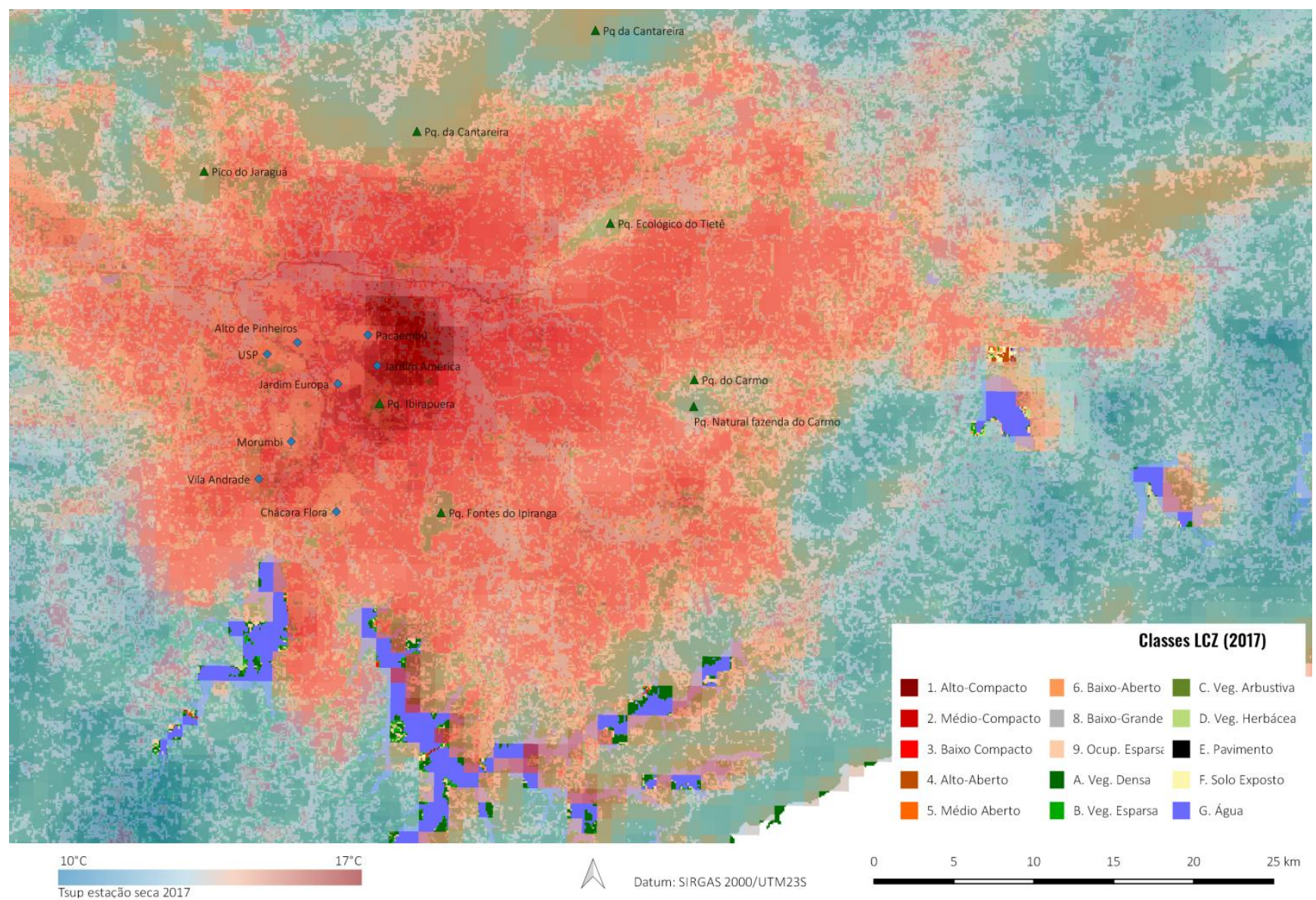

Figura 55. Sobreposição do mapa de $T_{\text {sup }}$ noturna da estação seca de 2017 com o mapa LCZ 2017. 
A Figura 56 e a Figura 57 apresentam as diferenças de temperaturas em relação à média.
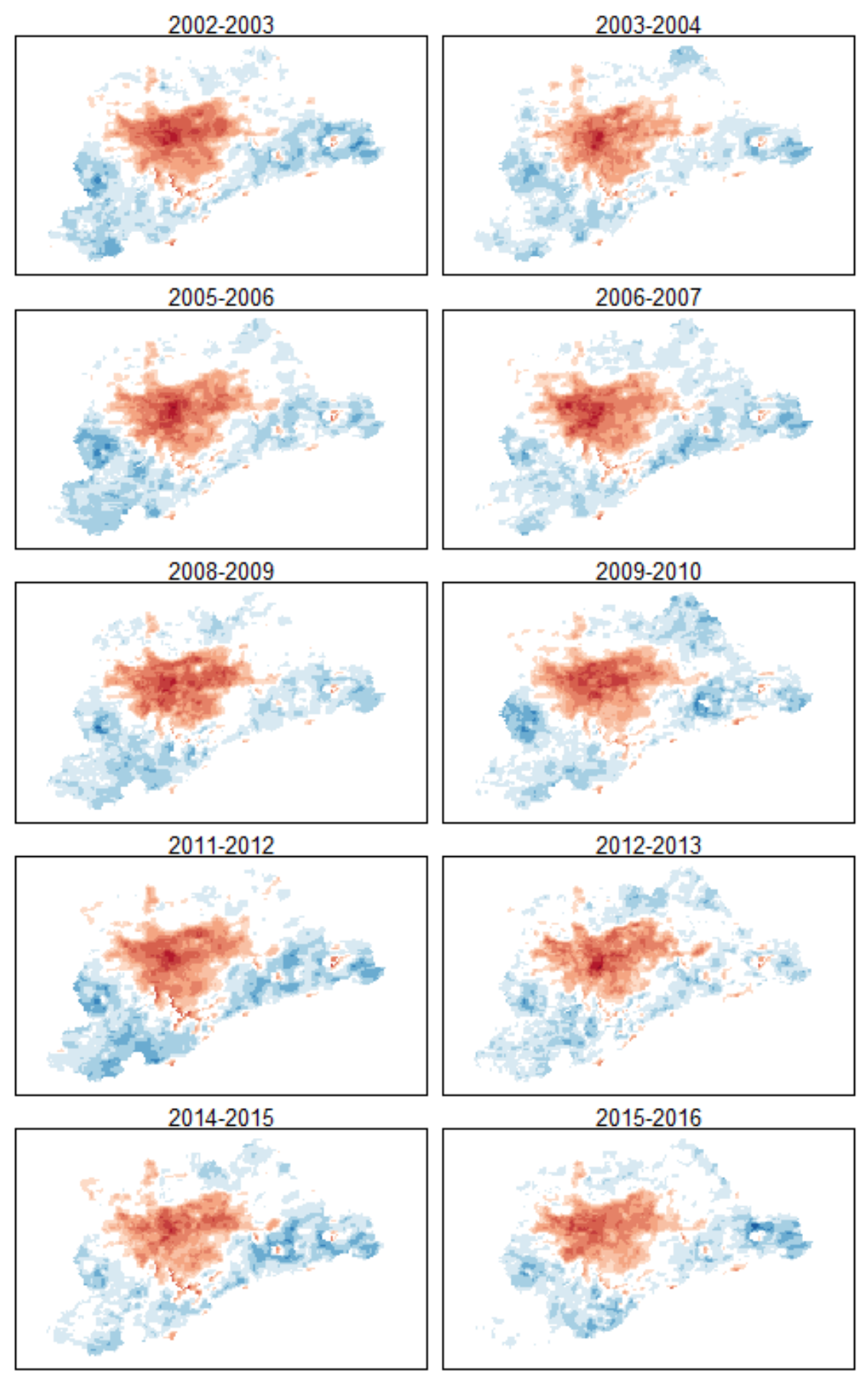

Temperatura Superfical $\left({ }^{\circ} \mathrm{C}\right)$

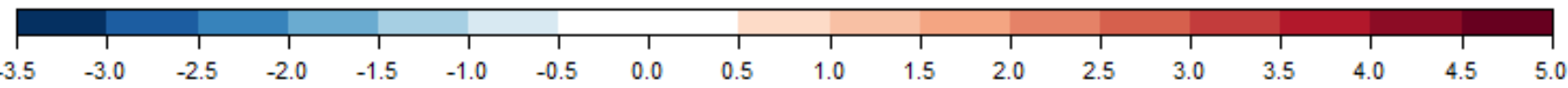

Figura 56. Diferença da $T_{\text {sup }}$ noturna de cada pixel em relação à temperatura média da RMSP. Estação chuvosa. 

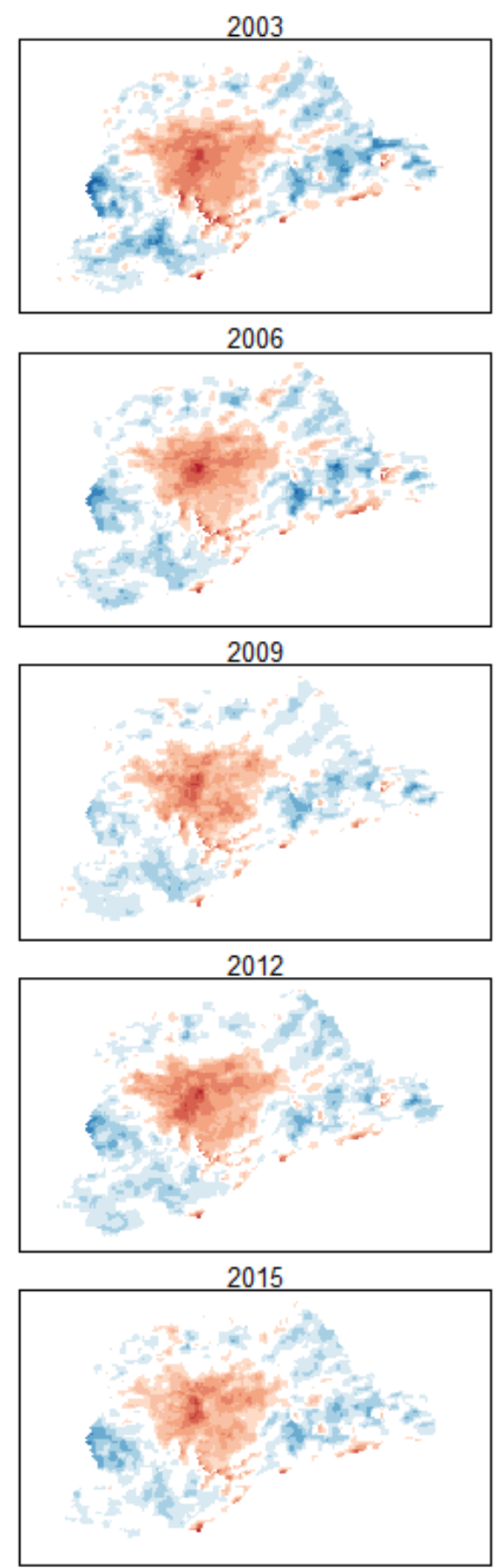

2015

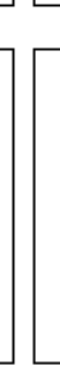

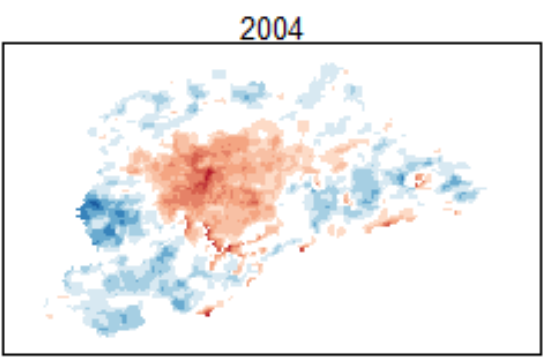
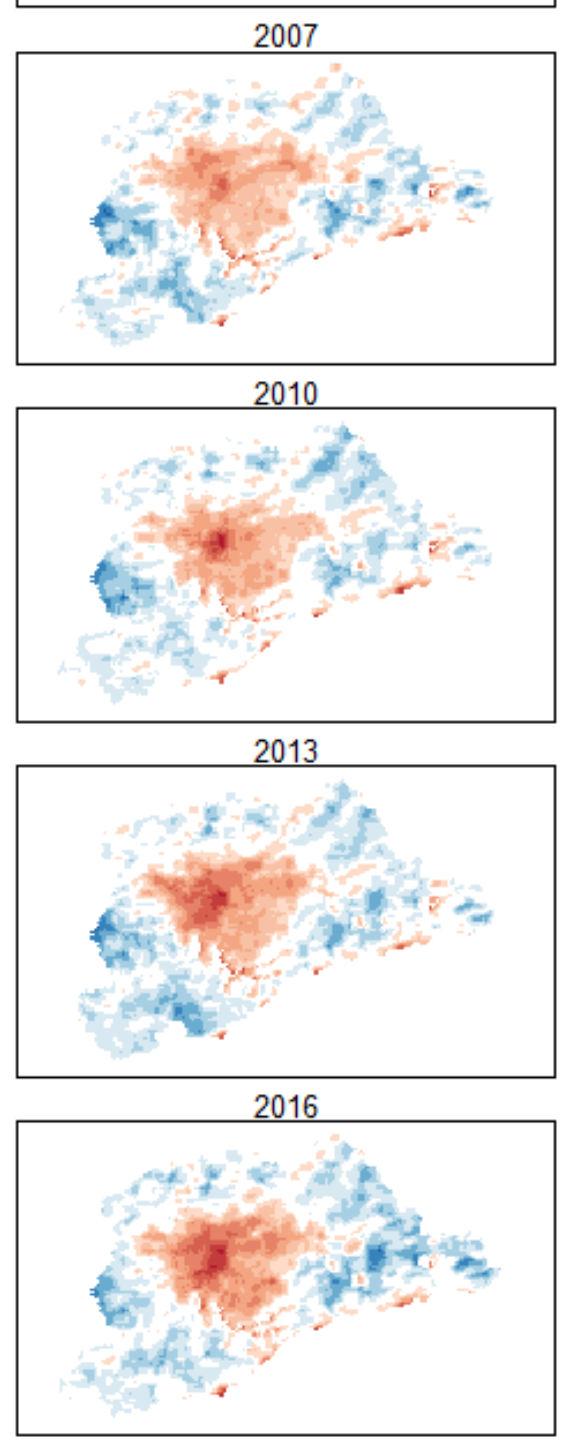

Temperatura Superfical $\left({ }^{\circ} \mathrm{C}\right)$
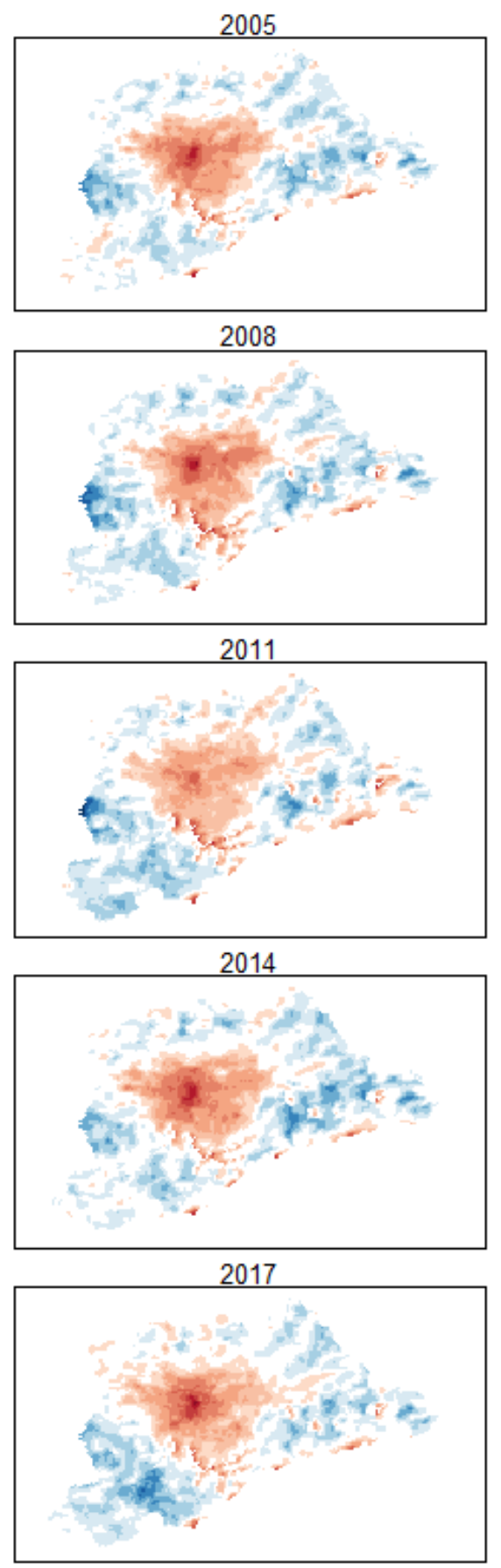

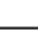

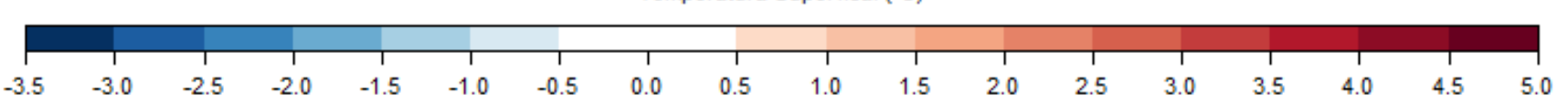

Figura 57. Diferença da $T_{\text {sup }}$ noturna de cada pixel em relação à temperatura média da RMSP. Estação Seca. 
Os resultados noturnos sugerem a ocorrência de ilha de calor superficial de acordo com a definição tradicional discutida no Capítulo 1.

Os padrões de $T_{\text {sup }}$ que se repetem ao longo da série temporal podem ser evidenciados em uma imagem média de toda a série. A Figura 58 e a Figura 59 apresentam as imagens médias diurnas das estações secas e chuvosas de 2002 a 2017, e a Figura 60 e a Figura 61 apresentam as imagens médias noturnas.

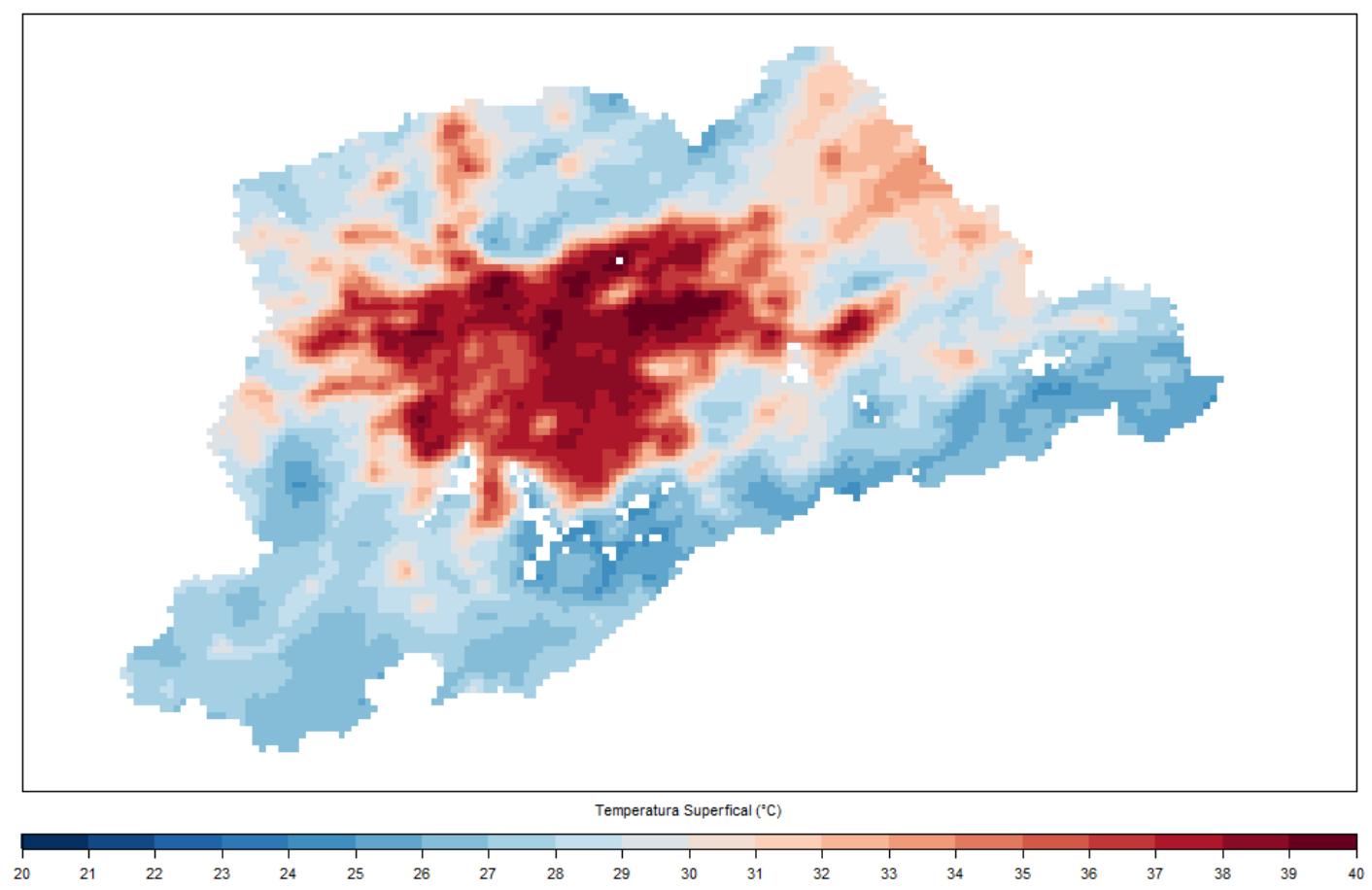

Figura 58. Imagem média diurna de todas as estações chuvosas. 


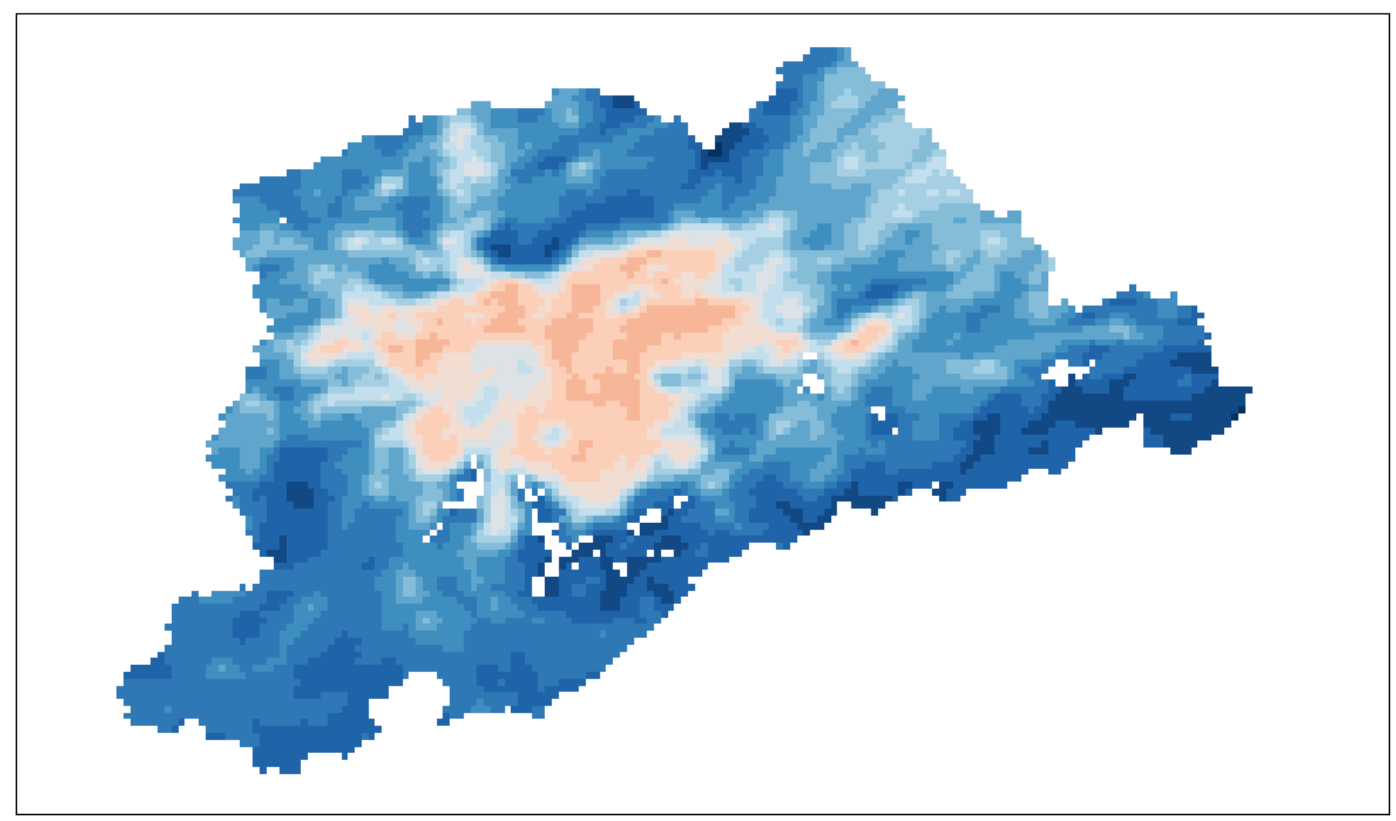

Temperatura Superfical $\left({ }^{\circ} \mathrm{C}\right)$

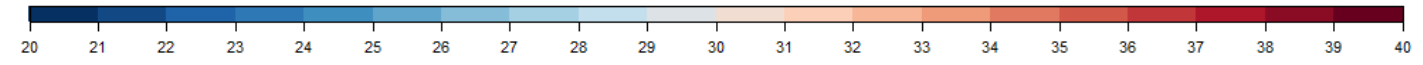

Figura 59. Imagem média diurna de todas as estações secas

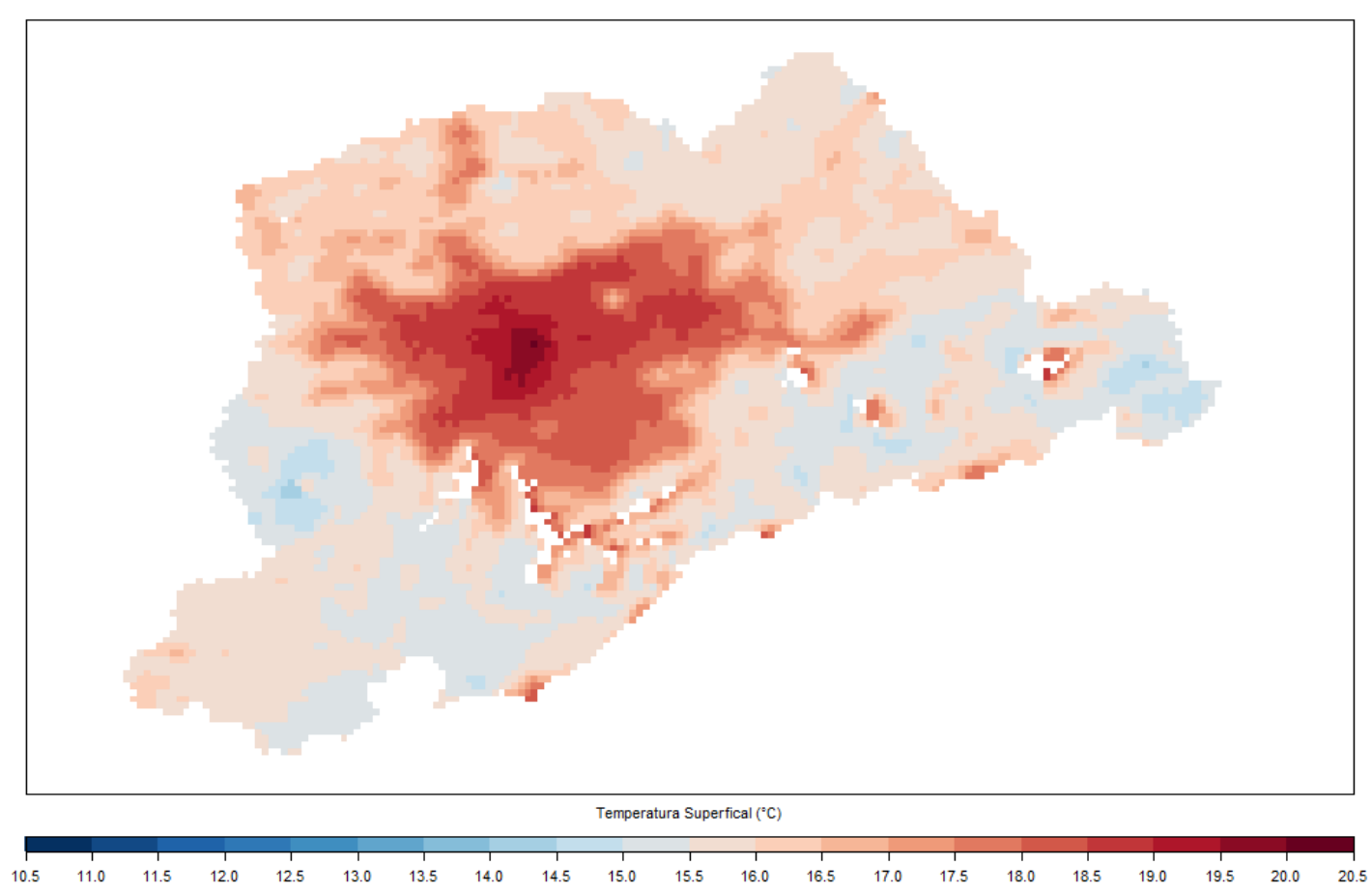

Figura 60. Imagem média noturna de todas as estações chuvosas. 


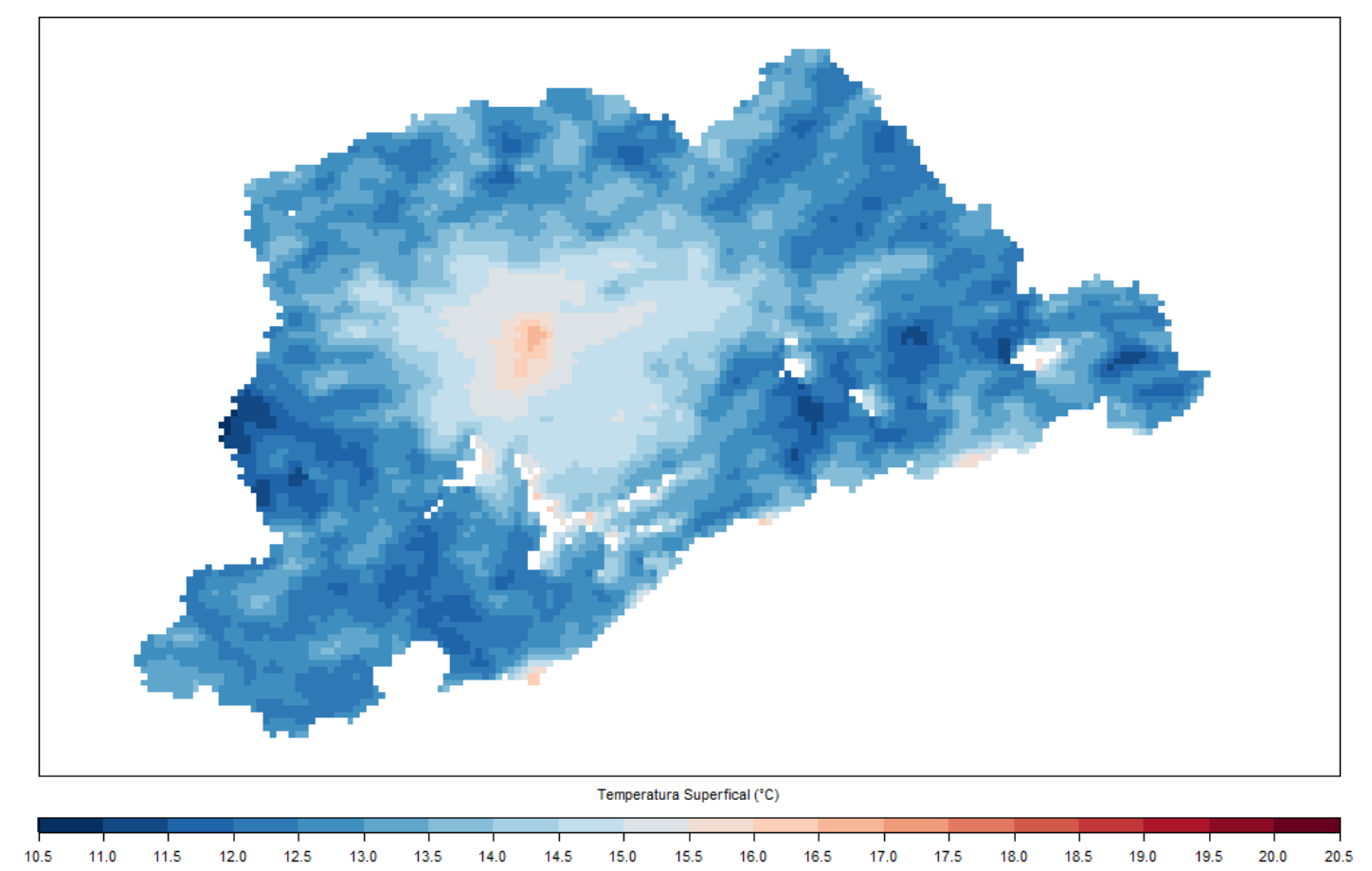

Figura 61. Imagem média noturna de todas as estações secas

As imagens médias dos 15 anos de dados reforçam o padrão de distribuição das temperaturas superficiais diurnas e noturnas na RMSP: áreas densamente construídas mais aquecidas que áreas não construídas tanto nas imagens diurnas quanto nas noturnas; a periferia densamente construída e horizontal mais aquecida que as áreas verticalizadas no centro da área urbana nas imagens diurnas e as áreas centrais verticalizadas mais aquecidas do que as áreas periféricas construídas nas imagens noturnas.

Áreas verticalizadas menos aquecidas durante o dia também foram verificadas por Sousa e Ferreira (2012) na cidade de Goiânia e evidenciam o papel da sombra na redução das temperaturas diurnas em áreas construídas.

A magnitude das diferenças entre as temperaturas máximas e mínimas ${ }^{41}$ observadas em uma mesma data (Tabela 10) pelo presente trabalho supera os valores anteriormente

${ }^{41}$ As temperaturas superficiais máximas e mínimas consideradas para o cálculo dessas diferenças não exclui dados discrepantes. 
verificados por Lombardo $(1985)^{42}$, de $10^{\circ} \mathrm{C}$ para a temperatura diurna, e por FLORES et al. (2016), de $10,4^{\circ} \mathrm{C}$ para temperatura diurna e de $3,8^{\circ} \mathrm{C}$ para noturna.

Tabela 10. Diferença entre temperaturas superficiais máximas e mínimas observadas em uma mesma data para a RMSP.

\begin{tabular}{|c|c|c|c|c|c|c|c|c|}
\hline \multirow[b]{3}{*}{ Diferença máxima } & \multicolumn{4}{|c|}{ Temperatura superficial diurna } & \multicolumn{4}{|c|}{ Temperatura superficial noturna } \\
\hline & \multicolumn{2}{|c|}{ Estação Chuvosa } & \multicolumn{2}{|c|}{ Estação Seca } & \multicolumn{2}{|c|}{ Estação Chuvosa } & \multicolumn{2}{|c|}{ Estação Seca } \\
\hline & $19,2^{\circ} \mathrm{C}$ & $2009 / 2010$ & $14,6^{\circ} \mathrm{C}$ & 2017 & $6,9^{\circ} \mathrm{C}$ & $2010 / 2011$ & $7,4^{\circ} \mathrm{C}$ & 2005 \\
\hline Diferença mínima & $16,4^{\circ} \mathrm{C}$ & $2005 / 2006$ & $11,7^{\circ} \mathrm{C}$ & 2011 & $5,2^{\circ} \mathrm{C}$ & $2008 / 2009$ & $5,6^{\circ} \mathrm{C}$ & $2008 / 2009$ \\
\hline Diferença média & $17,8^{\circ} \mathrm{C}$ & & $12,8^{\circ} \mathrm{C}$ & & $6,3^{\circ} \mathrm{C}$ & & $6,3^{\circ} \mathrm{C}$ & \\
\hline
\end{tabular}

O exame dos valores das temperaturas por morfologia (classes LCZ) contribui para a melhor discriminação das diferenças entre as tipologias. Assim, as temperaturas superficiais diurnas e noturnas de cada LCZ foram computadas para a estação chuvosa e seca dos anos de abrangência dos mapas. Para o mapa de LCZ 2002 foram verificadas as temperaturas superficiais diurnas e noturnas da estação chuvosa 2002/2003 (Figura 62) e seca 2003 (Figura 63). Para o mapa de LCZ 2010, foram consideradas as estações chuvosa 2009/2010 (Figura 64) e seca 2010 (Figura 65), e para o mapa de LCZ 2017, as estações chuvosa 2016/2017 (Figura 66) e seca 2017 (Figura 67). A variação das temperaturas em cada LCZ foi representada em gráficos do tipo boxplot ${ }^{43}$, ou caixa.

\footnotetext{
${ }^{42}$ Em seu estudo para a RMSP, Lombardo (1985) utilizou 8 cenas dos satélites TIROS e NOAA entre os anos de 1980 e 1982 e Flores et al. (2016) todas as cenas do satélite Terra-MODIS entre 2001 e 2014 com resolução espacial de 5,6km.

${ }^{43}$ Os gráficos do tipo boxplot, ou diagramas de caixas, representam graficamente a variação dos dados. A parte inferior da caixa representa o primeiro quartil dos dados, a parte superior representa o terceiro quartil e a linha mais espessa no centro da caixa representa a mediana. Assim, considera-se que 50\% dos dados encontram-se nos limites da caixa. As linhas verticais, inferior e superior, representam os limites dos dados e os pontos fora dessas margens, os dados discrepantes ou outliers.
} 
Estação Chuvosa 2002/2003

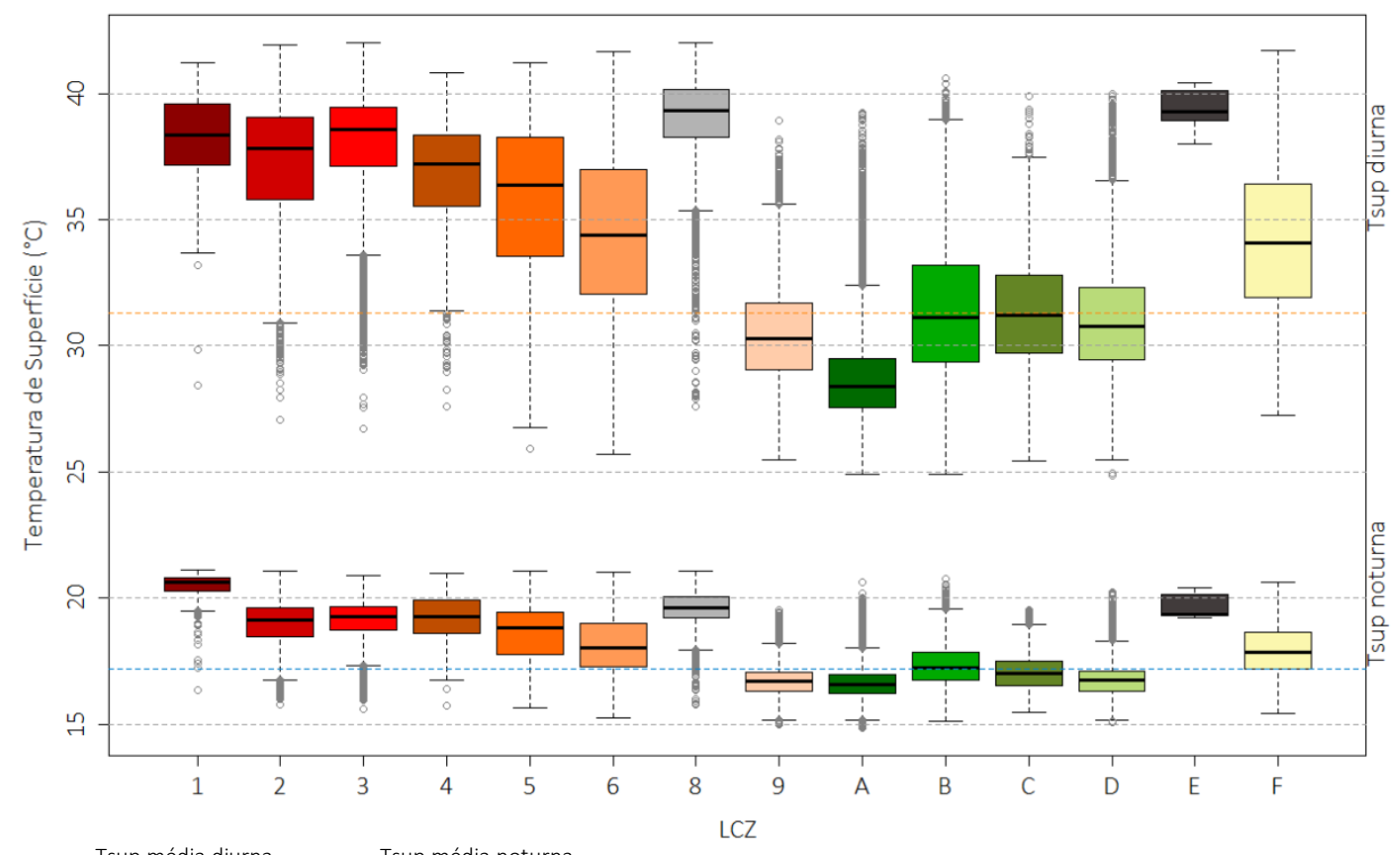

Tsup média diurna - - - - Tsup média noturna

Figura 62. $T_{\text {sup }}$ diurna e noturna por LCZ 2002. Estação Chuvosa 2002/2003

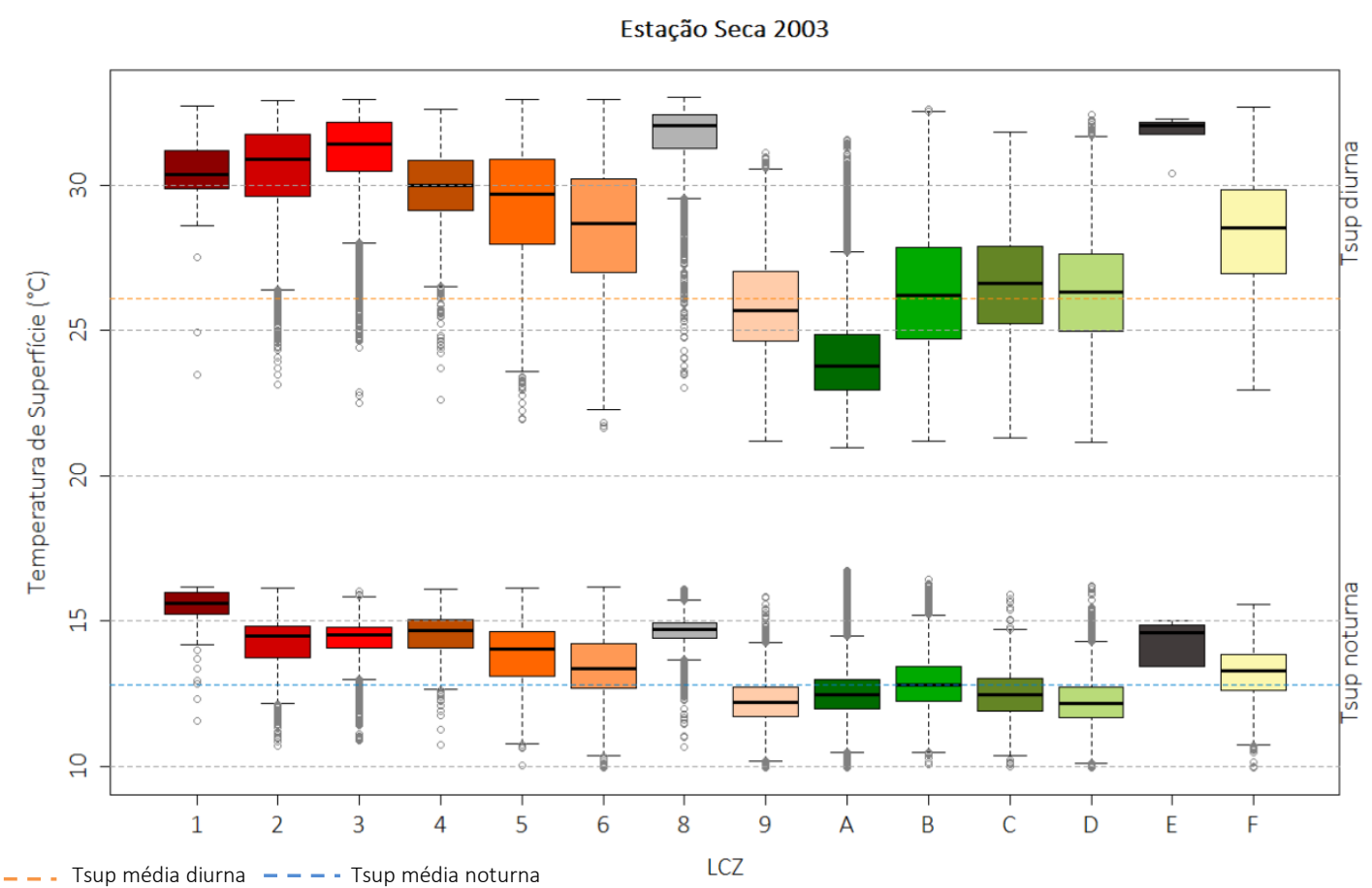

Figura 63. $T_{\text {sup }}$ diurna e noturna por LCZ 2002. Estação Seca 2003 


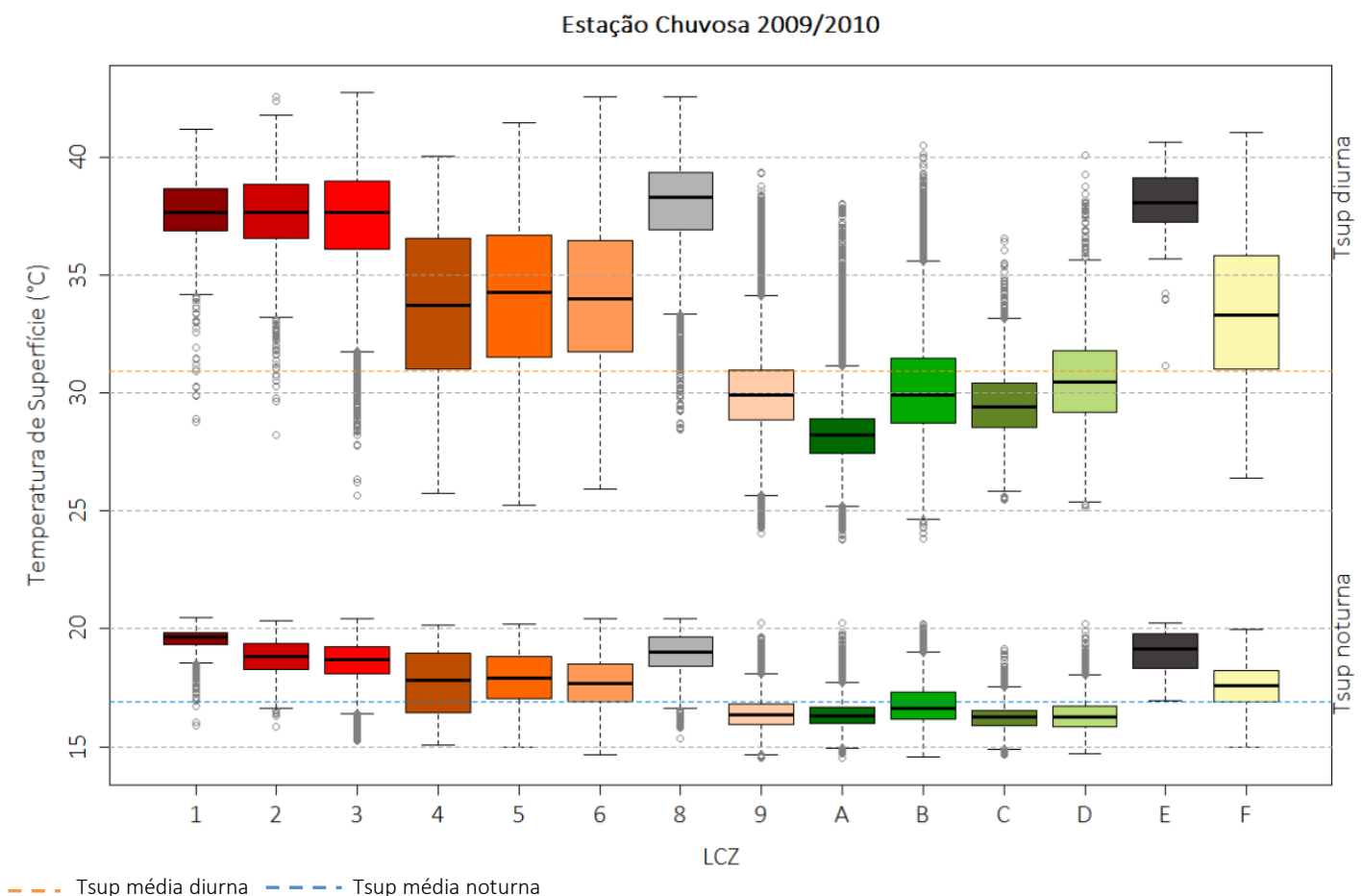

Figura 64. $T_{\text {sup }}$ diurna e noturna por LCZ 2010. Estação Chuvosa 2009/2010

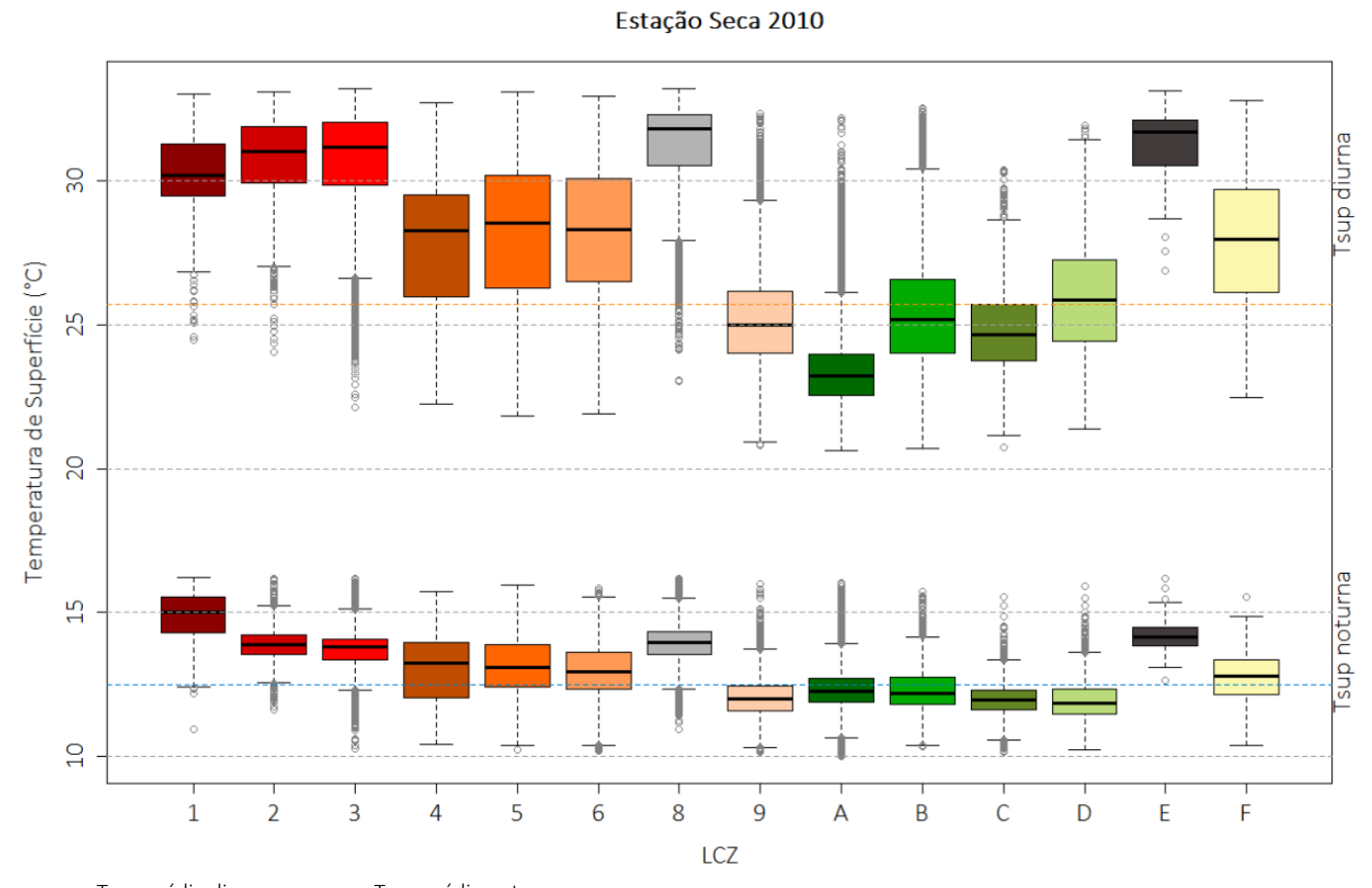

Figura 65. T Tsup diurna e noturna por LCZ 2010. Estação Seca 2010 


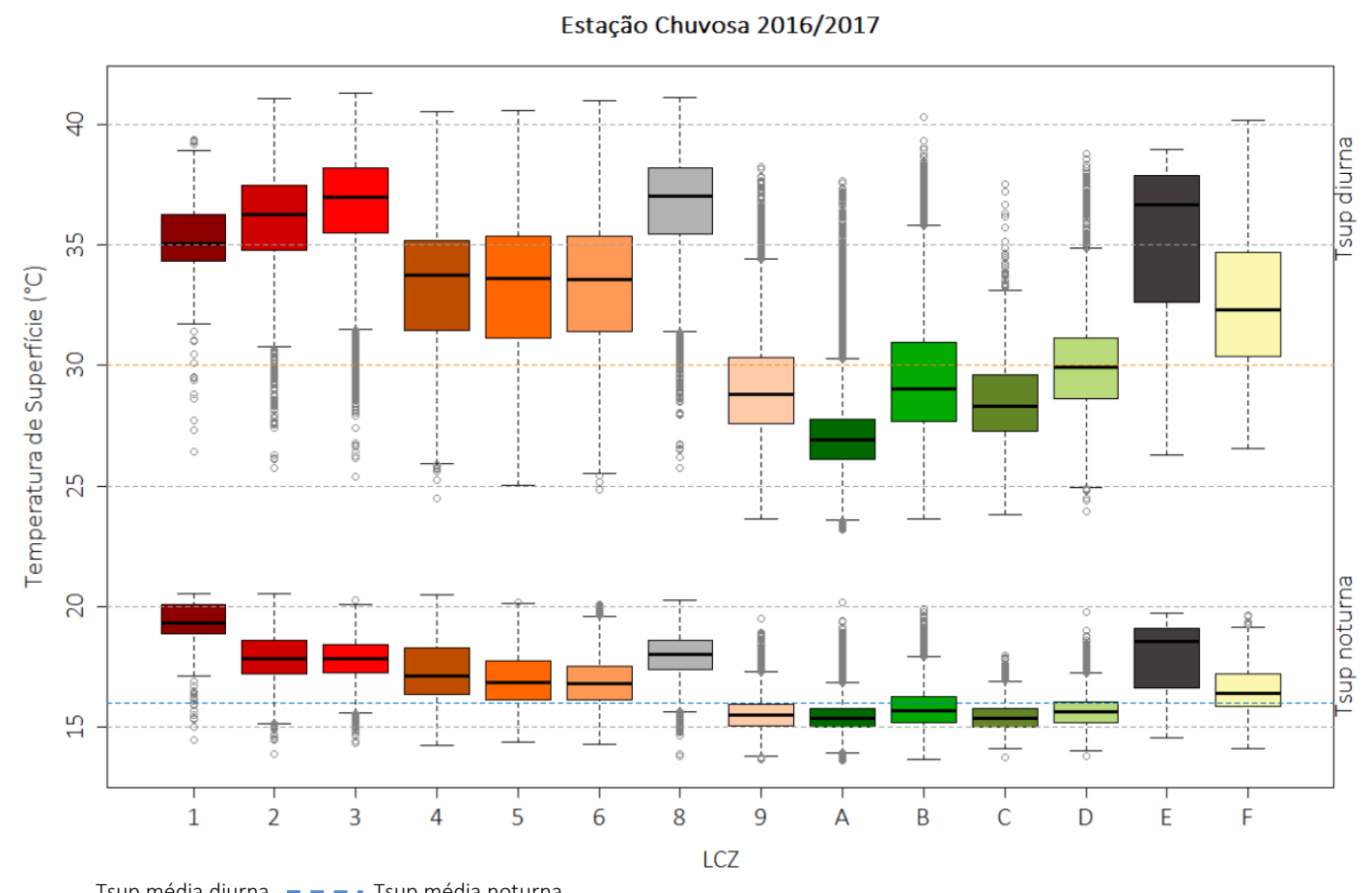

Figura 66. $T_{\text {sup }}$ diurna e noturna por LCZ 2017. Estação Chuvosa 2016/2017

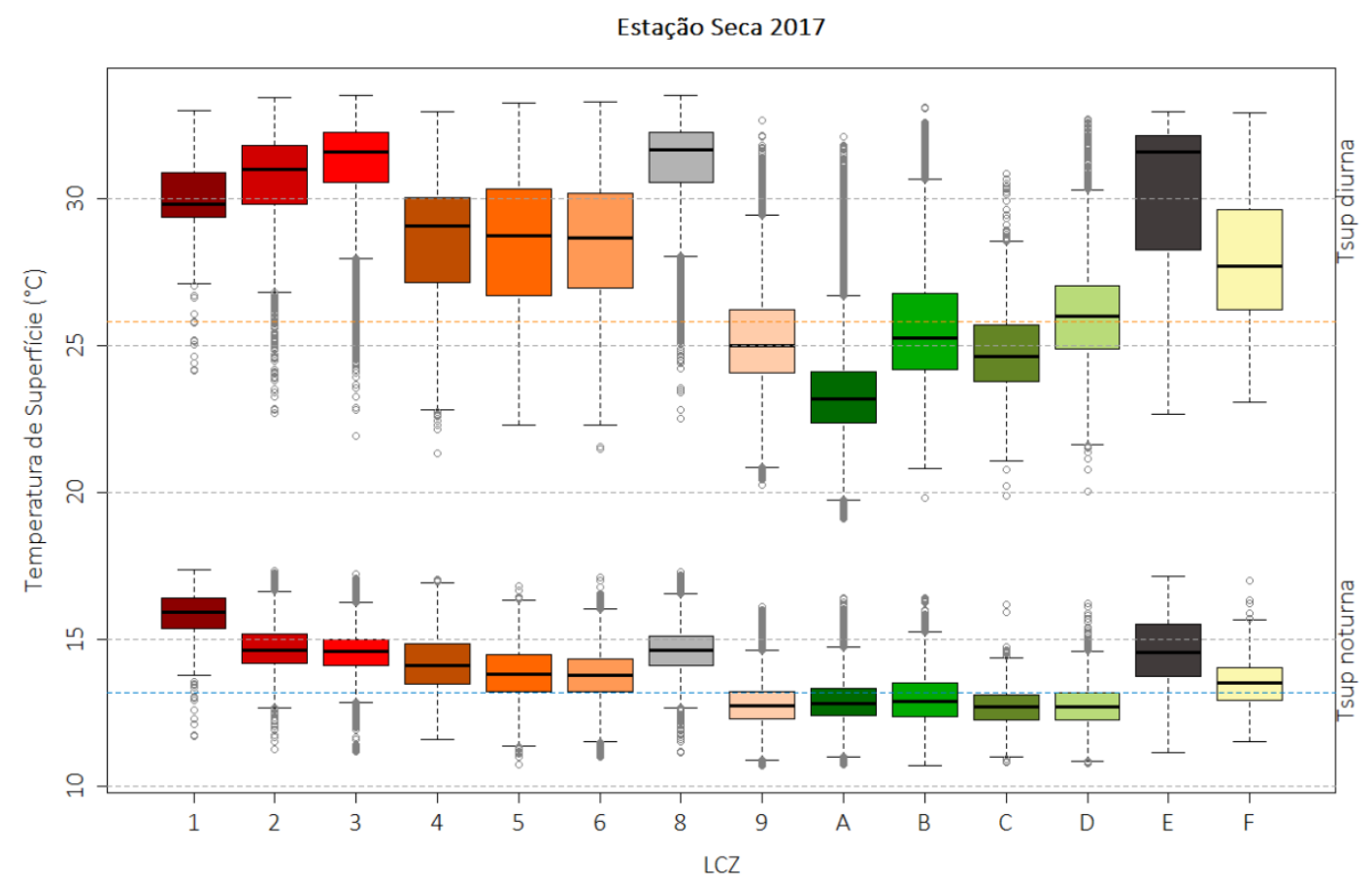

- - - - Tsup média diurna - - - - Tsup média noturna

Figura 67. T sup diurna e noturna por LCZ 2017. Estação Seca 2017. 
Para todos os anos analisados as temperaturas diurnas das tipologias construídas são superiores às temperaturas das tipologias vegetadas, sendo que as primeiras encontramse acima da temperatura média da RMSP em todos os anos, tanto de dia quanto à noite, com exceção da LCZ 9 (ocupação esparsa). A quantidade de vegetação presente nessa tipologia, e apresentada no item 4.1.3., possivelmente contribui para que suas temperaturas fiquem mais próximas das tipologias vegetadas.

A análise das medianas das temperaturas evidenciou que: dentre as tipologias construídas, a LCZ 3 (Baixo-Compacto) e a LCZ 8(Baixo-Grande) apresentam Tsup diurna superior às demais classes construídas, com exceção da Estação Chuvosa 2009/2010 na qual as temperaturas das LCZ 1 (Alto-Compacto), LCZ 2 (Médio-Compacto) e LCZ 3 (BaixoCompacto) apresentam valores equivalentes. A LCZ 1 (Alto-Compacto) apresenta $T_{\text {sup }}$ noturna superior às demais classes construídas em todos os anos.

Dentre as tipologias vegetadas a LCZ B (Vegetação arbórea esparsa) apresentou $T_{\text {sup }}$ diurna equivalente ou ligeiramente superior à LCZ C (Vegetação arbustiva) e à LCZ D (Vegetação herbácea). Isso pode ocorrer por incertezas da classificação, ou devido ao fato de que algumas áreas com cobertura vegetal esparsa apresentam solo impermeabilizado, o que elevaria as temperaturas superficiais diurnas.

Durante o dia a $T_{\text {sup }}$ da LCZ A (Vegetação arbórea densa) é inferior às das demais classes vegetadas, porém, nas imagens noturnas, as classes LCZ C (Vegetação arbustiva) e LCZ D (Vegetação herbácea) apresentam temperatura semelhante ou ligeiramente inferior à LCZ A (Vegetação arbórea densa). Possivelmente a biomassa presente nas áreas de vegetação mais densa contribui para seu lento resfriamento no período noturno, como verificado por MENDES et al. (2015) em estudo realizado com imagens termais de alta resolução na cidade de Piracicaba (SP). 


\subsection{3 Índices de vegetação}

Foram elaboradas imagens médias dos índices de vegetação NDVI e EVI para as estações secas e chuvosas para todos os anos de análise. Os índices de vegetação são originalmente adquiridos com 250 m de resolução espacial e, por isso, nesse item, serão apresentadas as imagens médias com essa resolução. Da mesma forma que as imagens termais, foram examinadas as médias calculadas a partir de todas as imagens disponíveis e a partir daquelas com mais de $50 \%$ de pixels válidos, optando-se pelas últimas.

O NDVI apresentou valores máximos de 0,93 tanto nas estações chuvosas (Figura 68) quanto nas estações secas (Figura 69). Já o EVI apresentou valores máximos de 0,73 nas estações chuvosas (Figura 70) e de 0,75 nas estações secas (Figura 71). Foi atribuída a mesma escala cromática para todos os anos de uma mesma variável e estação para melhor comparação entre as imagens.

Os valores mais elevados do NDVI em relação ao EVI eram esperados, visto que o NDVI pode apresentar saturação em áreas com maior quantidade de biomassa (HUETE et al., 2002b). 


\section{NDVI (Índice de vegetação por diferença normalizada)}
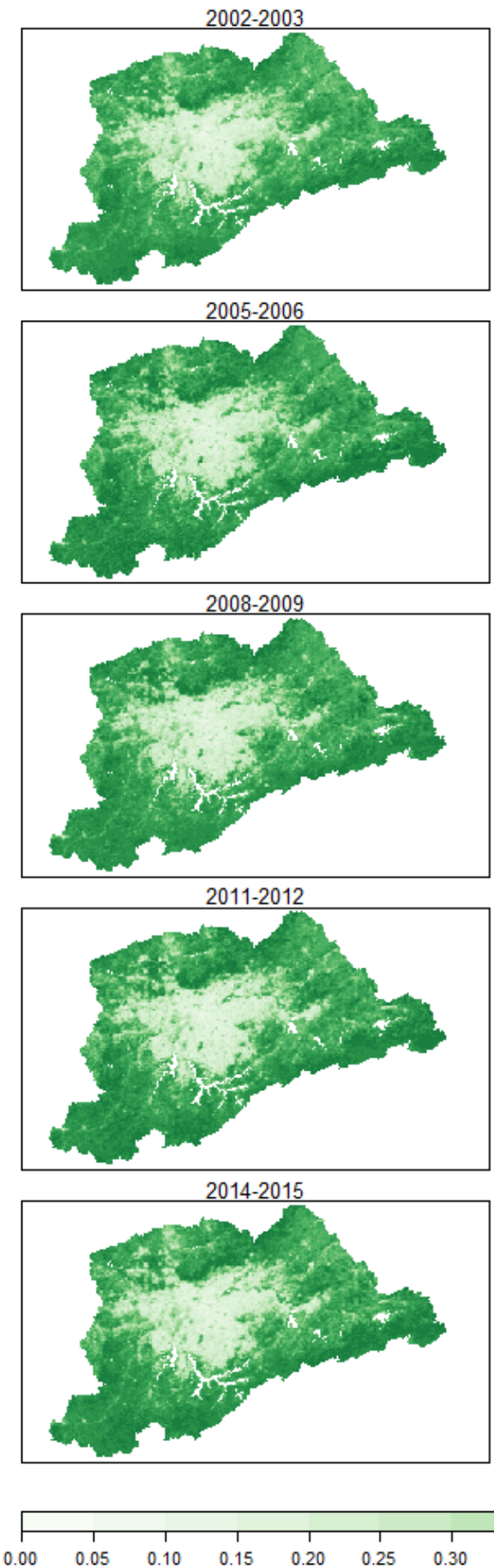

Figura 68. NDVI das estações chuvosas.
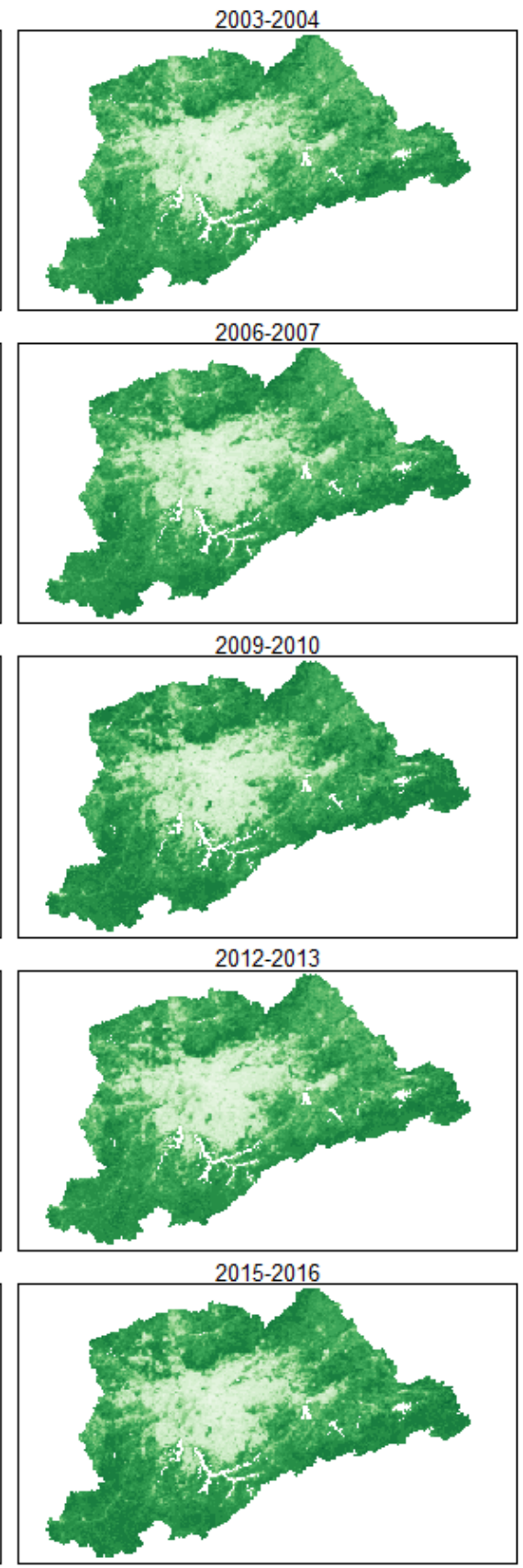

NDVI
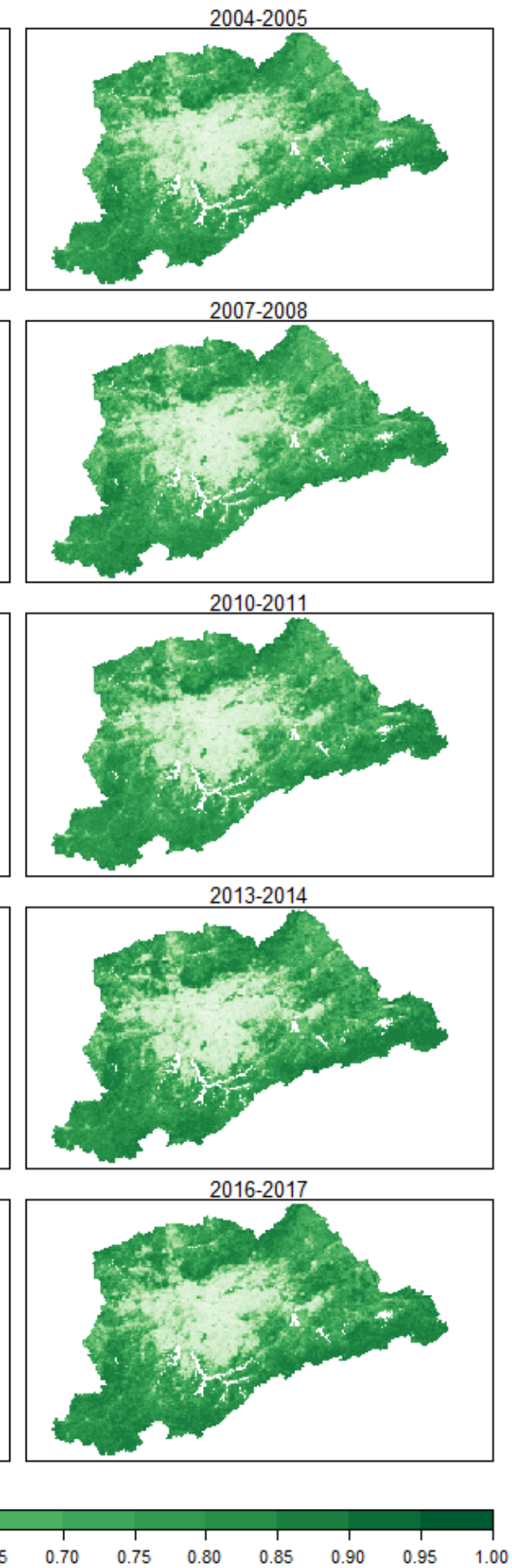

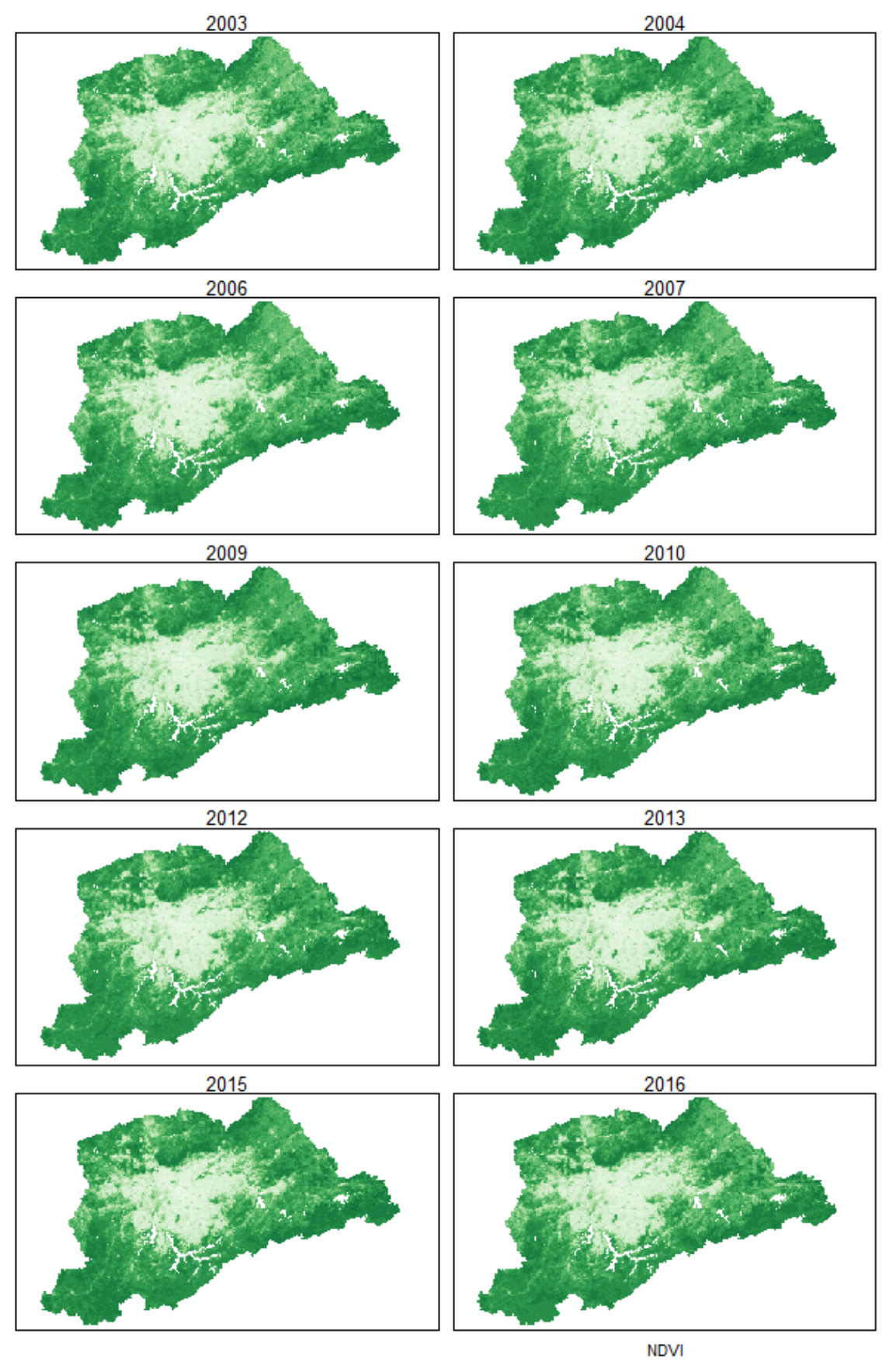

NDVI
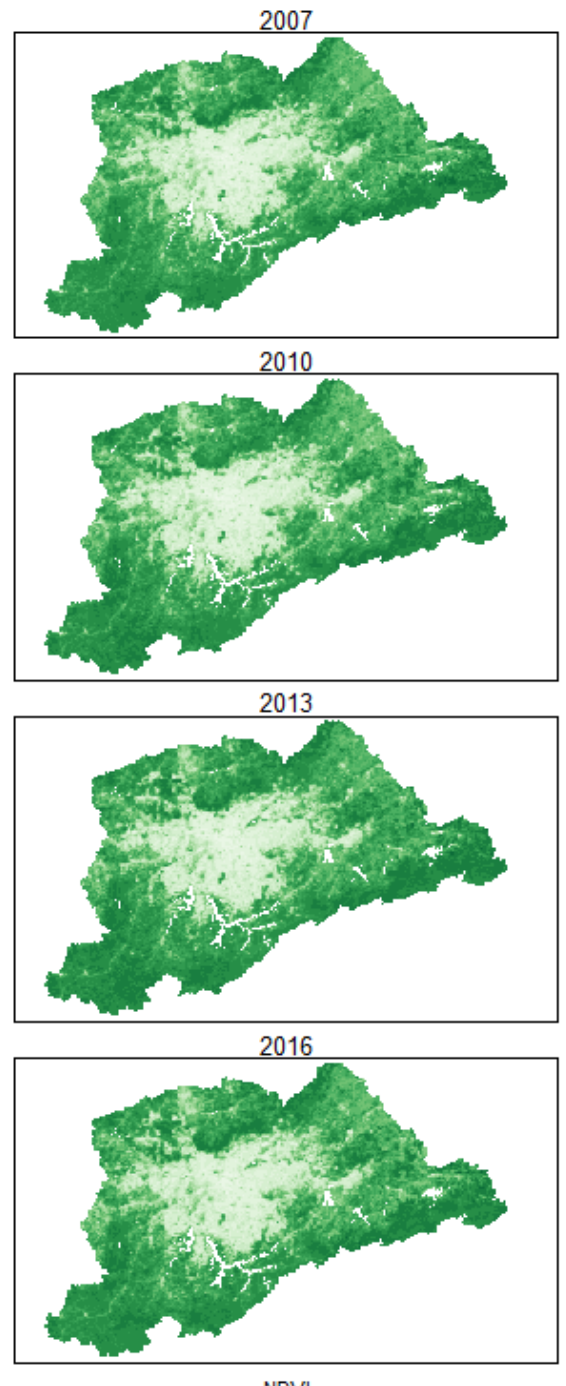

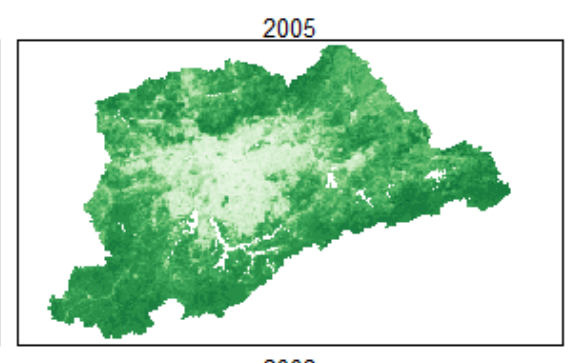

2008
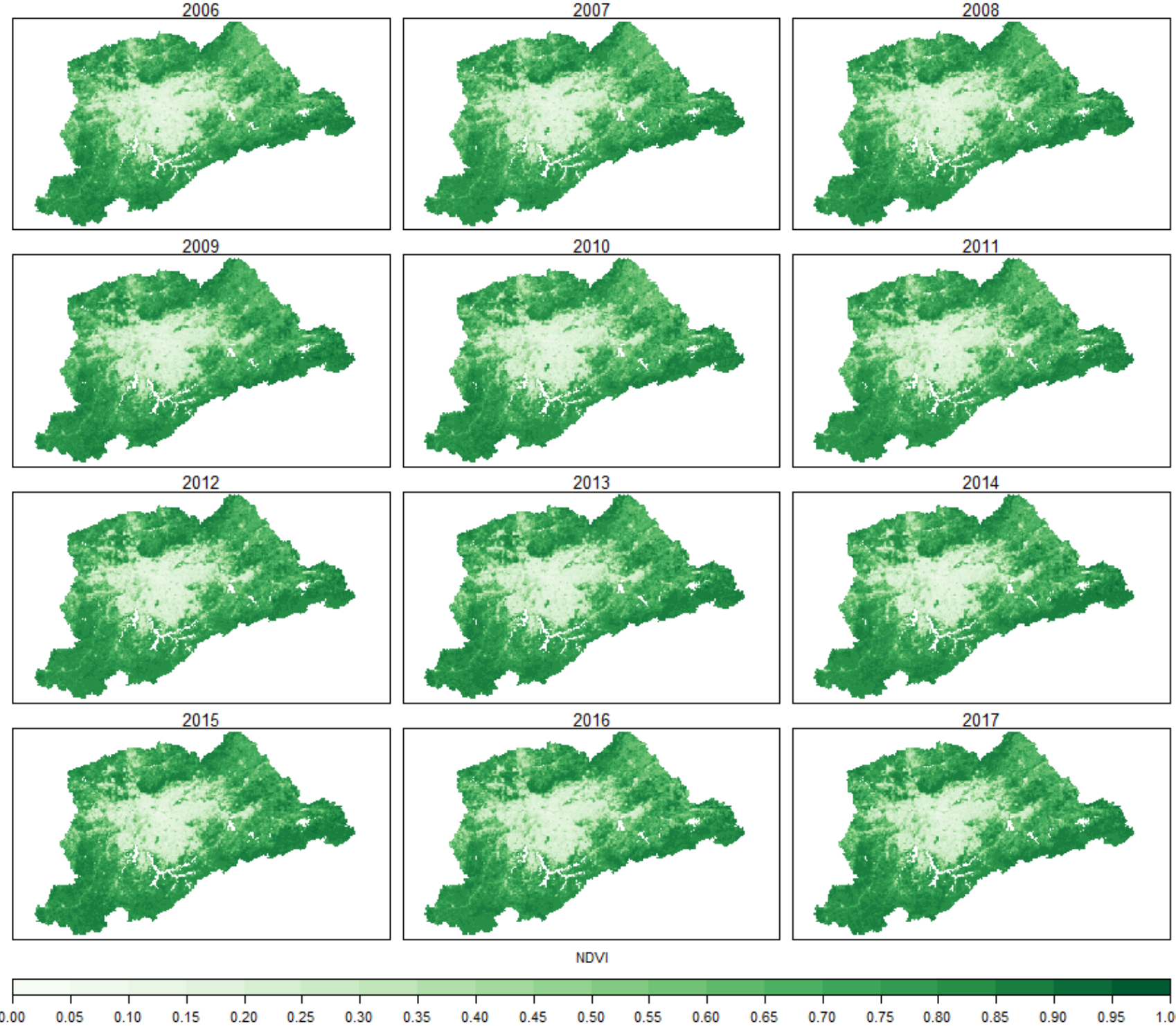

0.35
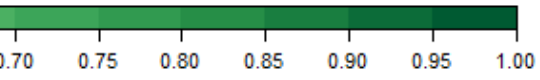

Figura 69. NDVI das estações secas. 


\section{EVI (Índice de vegetação realçado)}
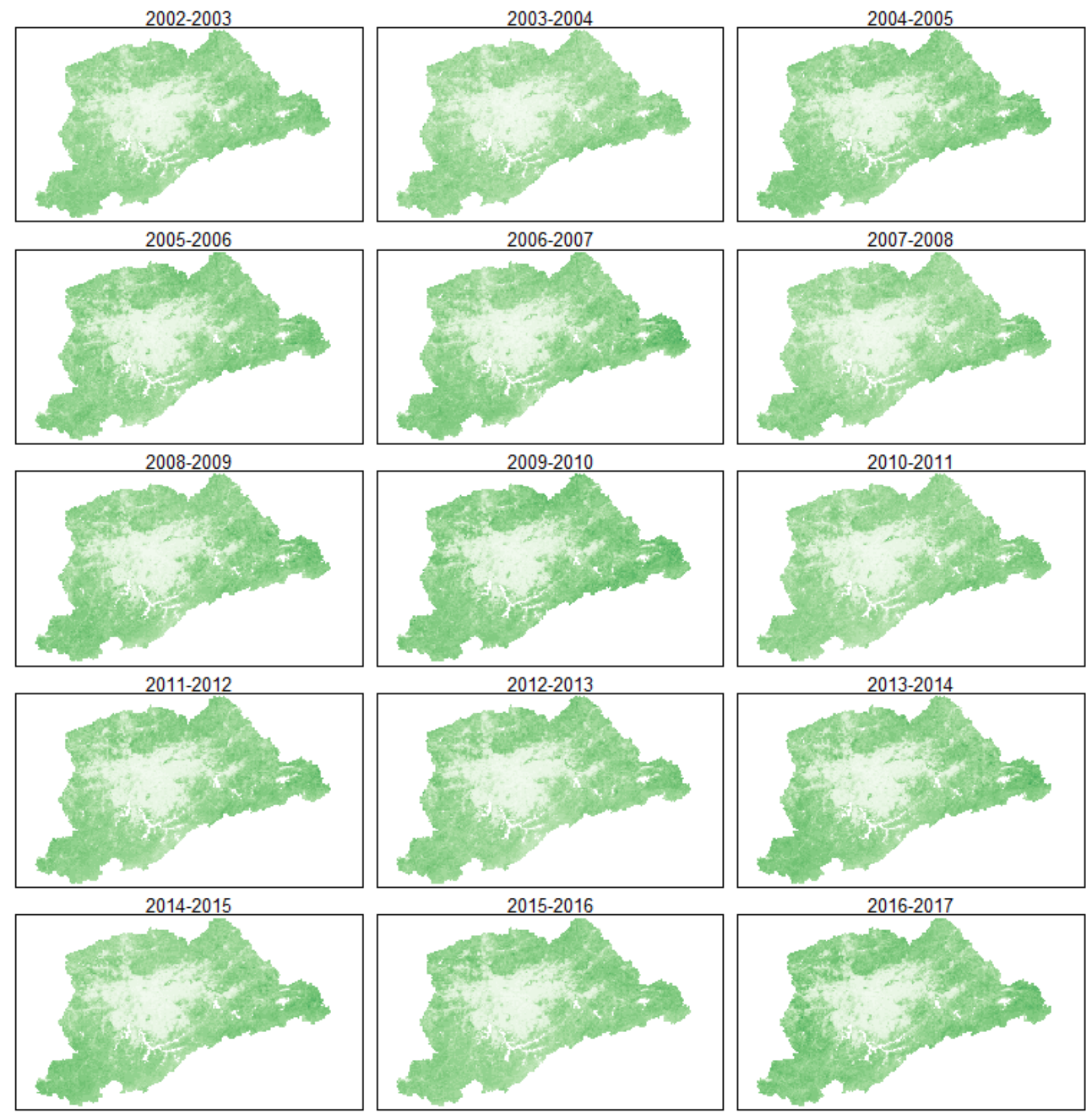

EVI

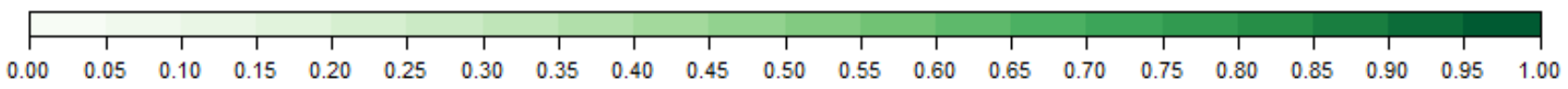

Figura 70. EVI das estações chuvosas. 

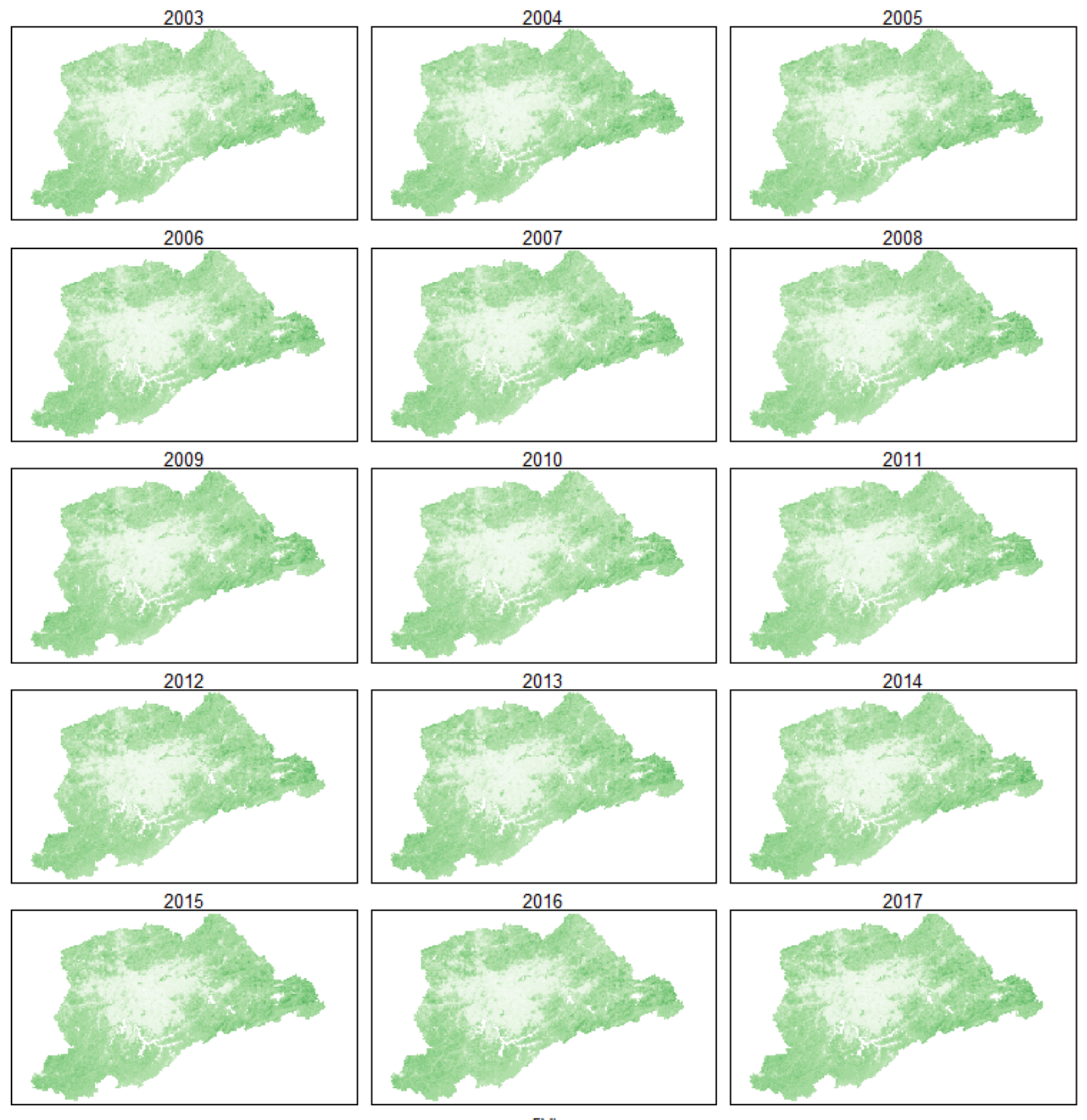

EVI

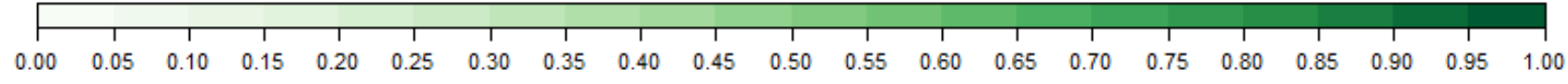

Figura 71. EVI das estações secas. 
Conforme esperado, a área urbanizada apresenta os menores valores dos índices de vegetação ${ }^{44}$ em todos os anos. Os maiores valores são verificados nas áreas vegetadas, com menor ocupação humana. A Figura 72 apresenta os valores de NDVI para a estação chuvosa de 2017 como exemplo. Assim como verificado no caso das temperaturas superficiais, existem diferenças nos índices no interior da área urbanizada. Além das áreas protegidas, como parques, destacam-se os já mencionados bairros da região sudoeste do município de São Paulo.

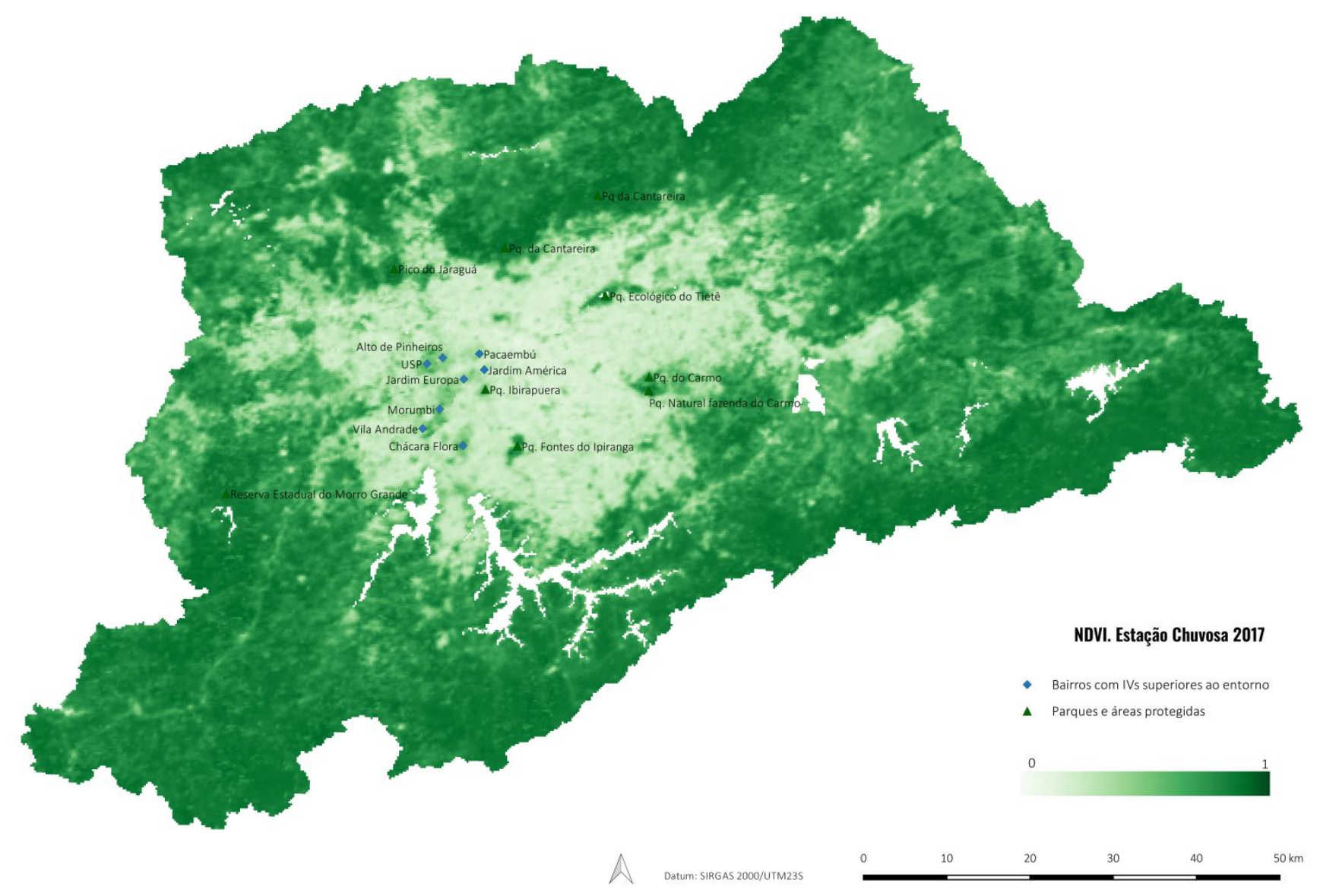

Figura 72. NDVI da estação chuvosa de 2017.

A sobreposição da imagem do NDVI da estação chuvosa de 2017 ao mapa de morfologia LCZ do mesmo ano (Figura 73) evidencia que entre as LCZ construídas, a LCZ 6 (Baixo-

\footnotetext{
${ }^{44}$ Conforme descrito no Capítulo 3 os corpos d' água foram previamente excluídos das imagens e, após o cálculo dos valores médios, pixels com valores negativos, que indicam presença de água, foram excluídos.
} 
aberto), a LCZ 4 (Alto-aberto) e a LCZ 9 (Ocupação esparsa) coincidem espacialmente com as áreas de maior NDVI.

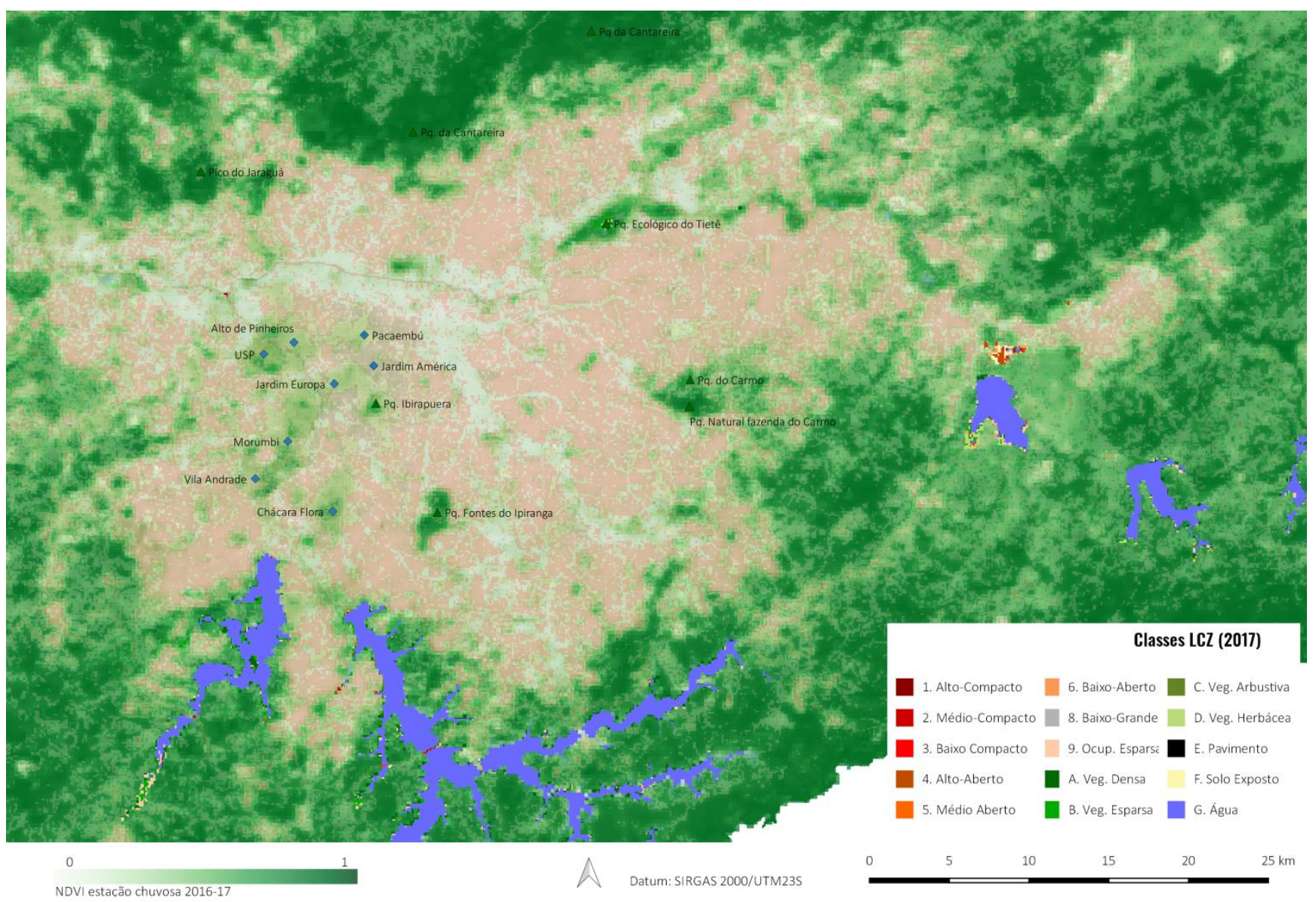

Figura 73. NDVI da estação chuvosa de 2017 sobre mapa LCZ de 2017.

O exame dos índices de vegetação por morfologia (classe LCZ) contribui para a melhor discriminação das diferenças entre as tipologias. Foram computados, para cada LCZ, os índices de vegetação correspondente para a estação chuvosa e seca dos anos de abrangência dos mapas (Figura 74 à Figura 85). 


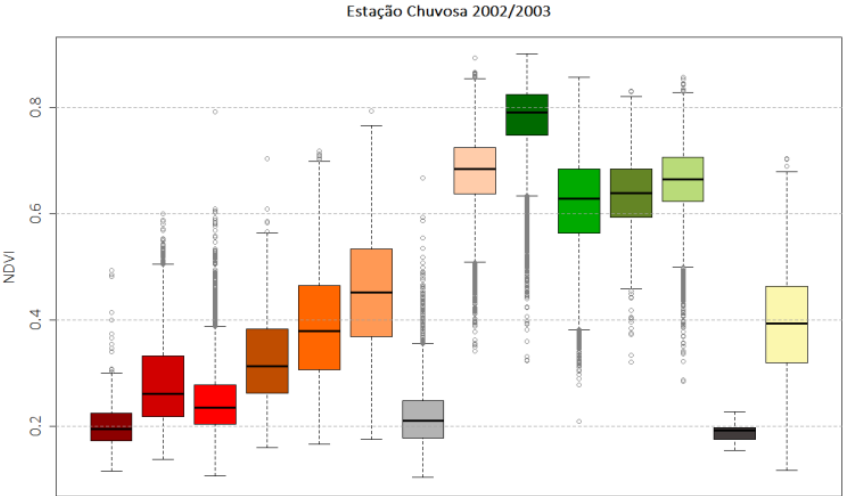

LCZ

Figura 74. NDVI por LCZ 2002. Estação Chuvosa 2002/2003.

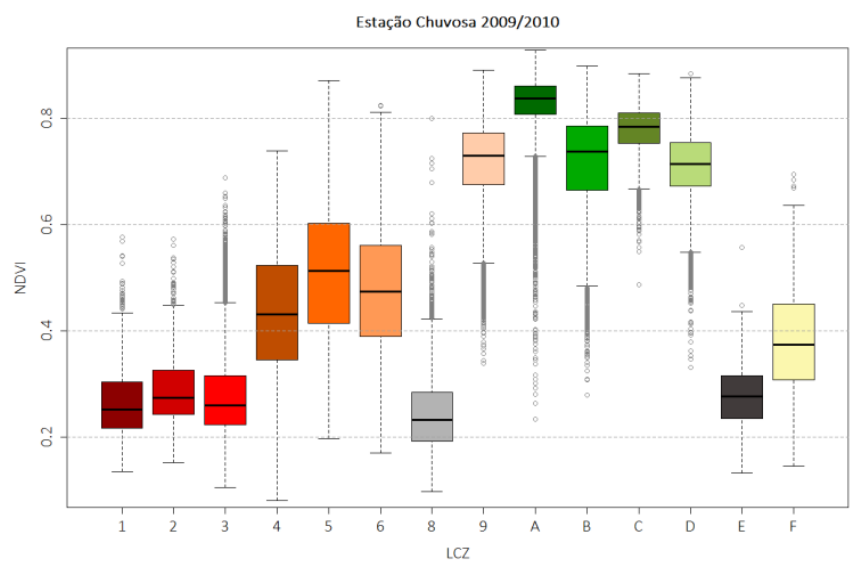

Figura 76. NDVI por LCZ 2010. Estação Chuvosa 2009/2010

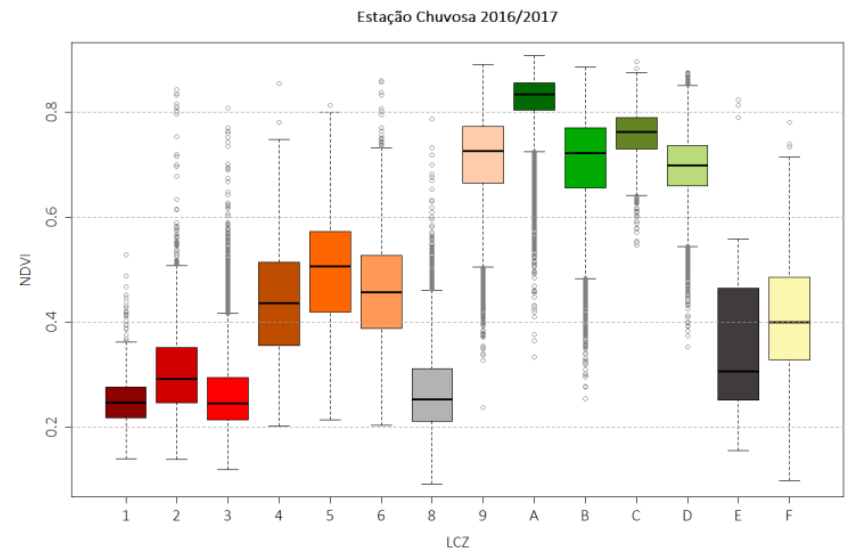

Figura 78. NDVI por LCZ 2017. Estação Chuvosa 2016/2017

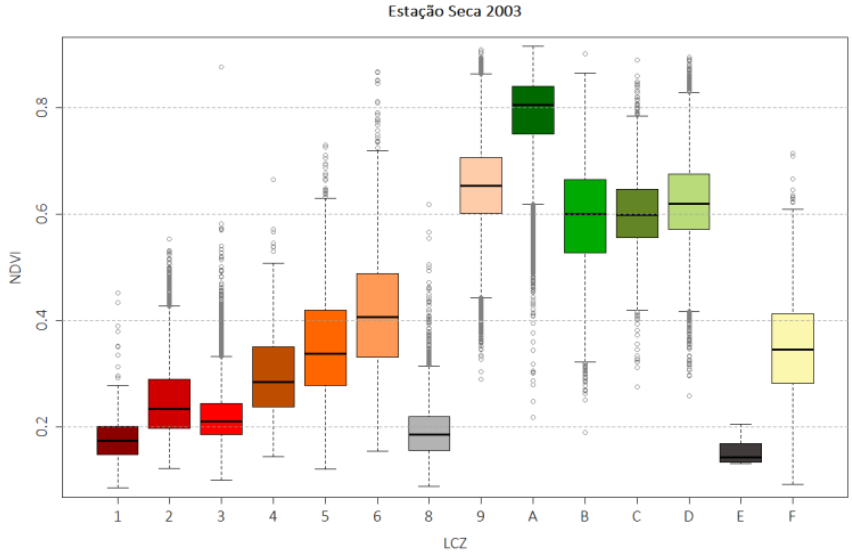

Figura 75. NDVI por LCZ 2002. Estação Seca 2003.

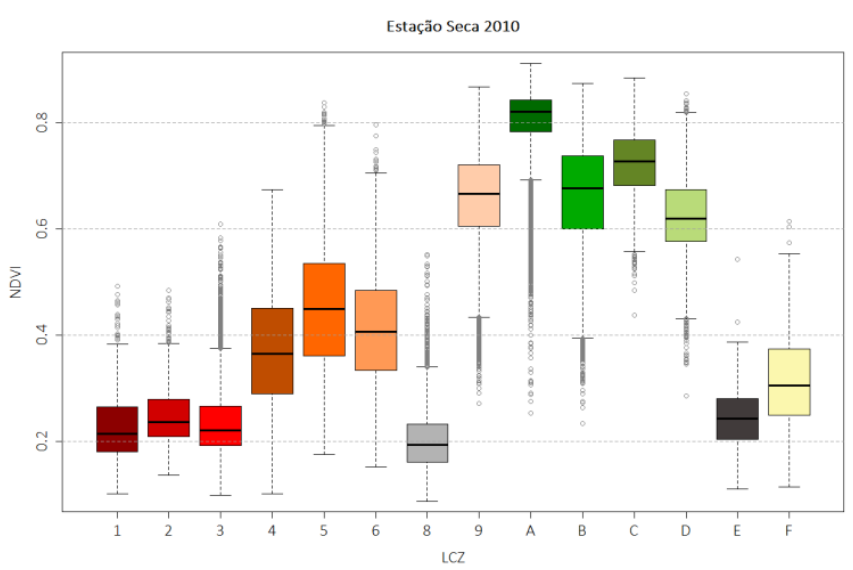

Figura 77. NDVI por LCZ 2010. Estação Seca 2010.

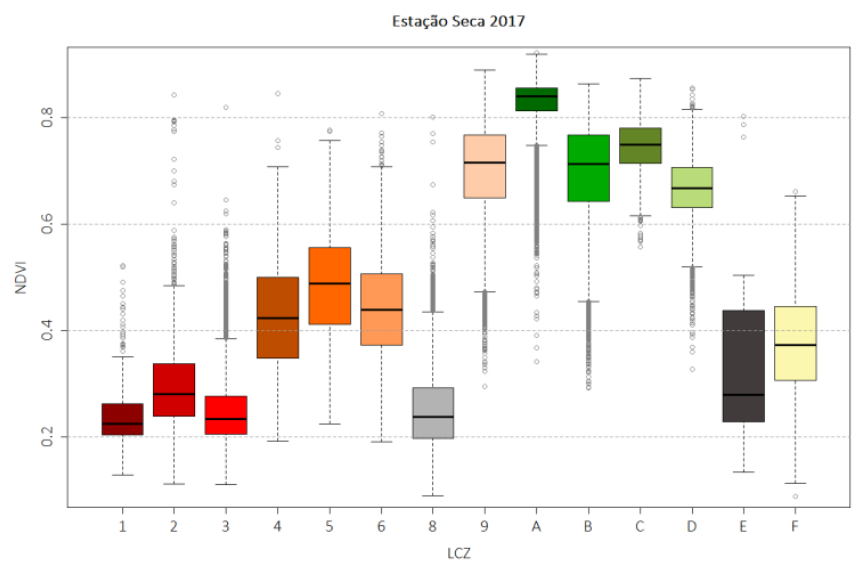

Figura 79. NDVI por LCZ 2017 Estação Seca 2017. 


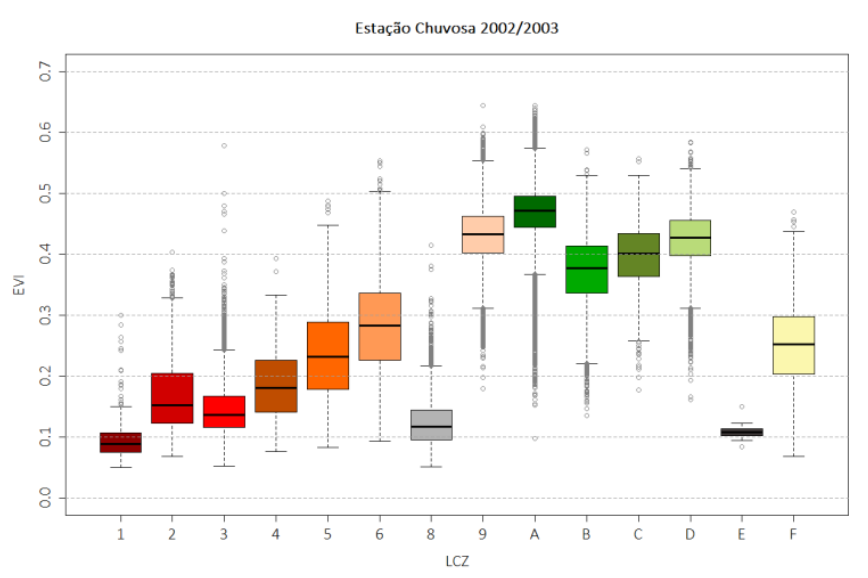

Figura 80. EVI por LCZ 2002. Estação Chuvosa 2002/2003.

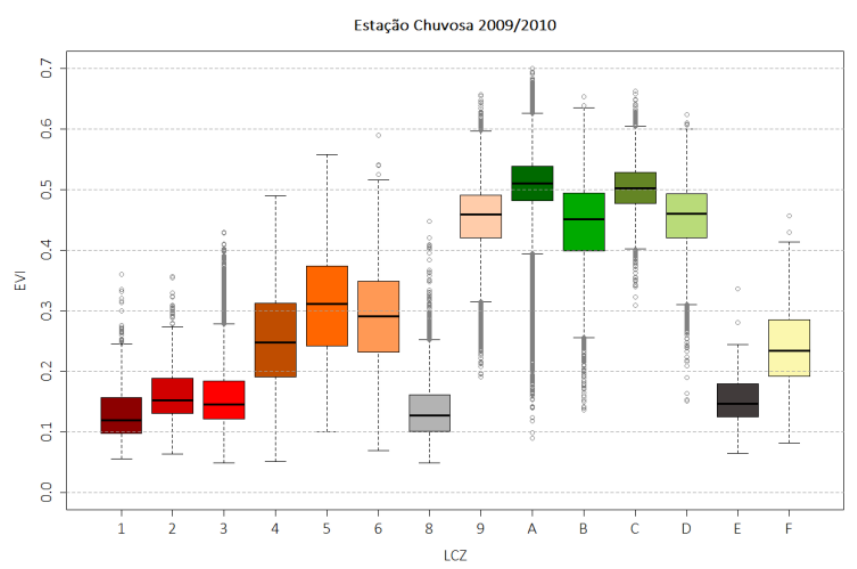

Figura 82. EVI por LCZ 2010. Estação Chuvosa 2009/2010

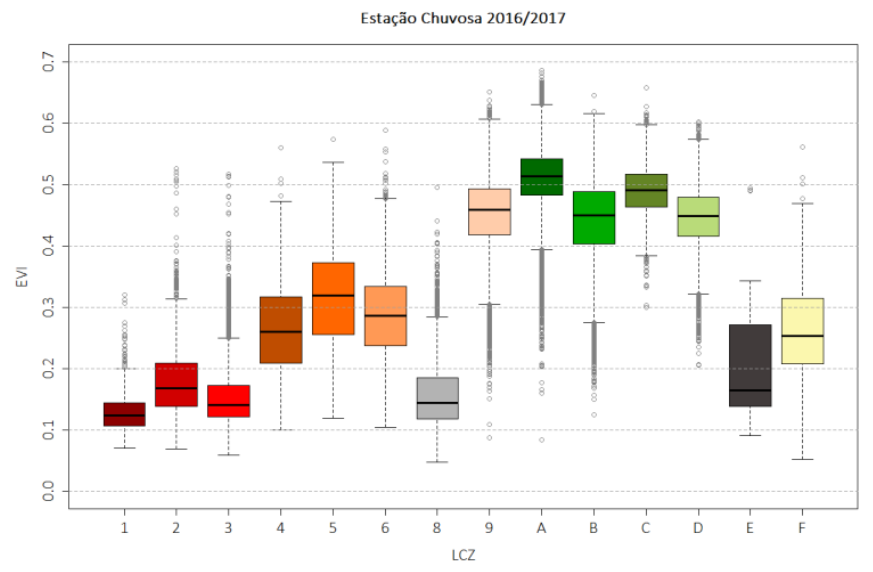

Figura 84. EVI por LCZ 2017. Estação Chuvosa 2016/2017

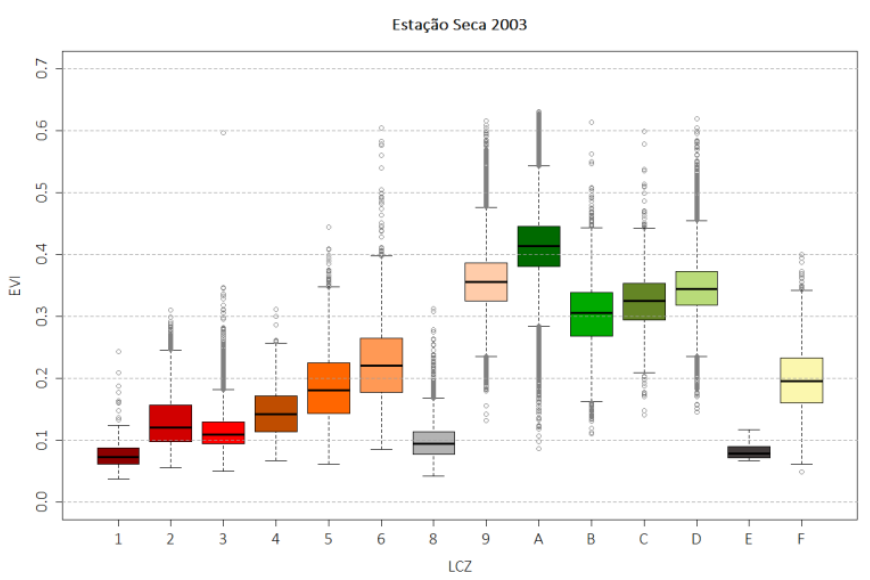

Figura 81. EVI por LCZ 2002. Estação Seca 2003.

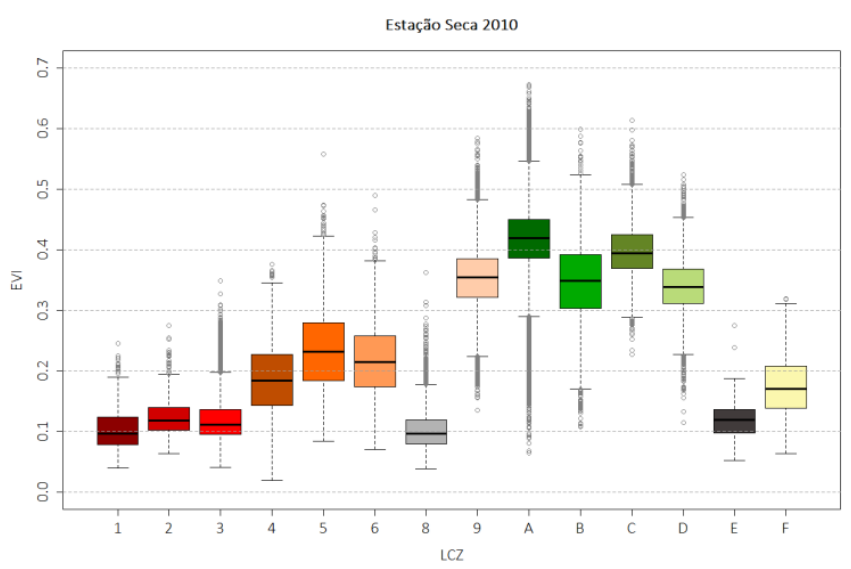

Figura 83. EVI por LCZ 2010. Estação Seca 2010.

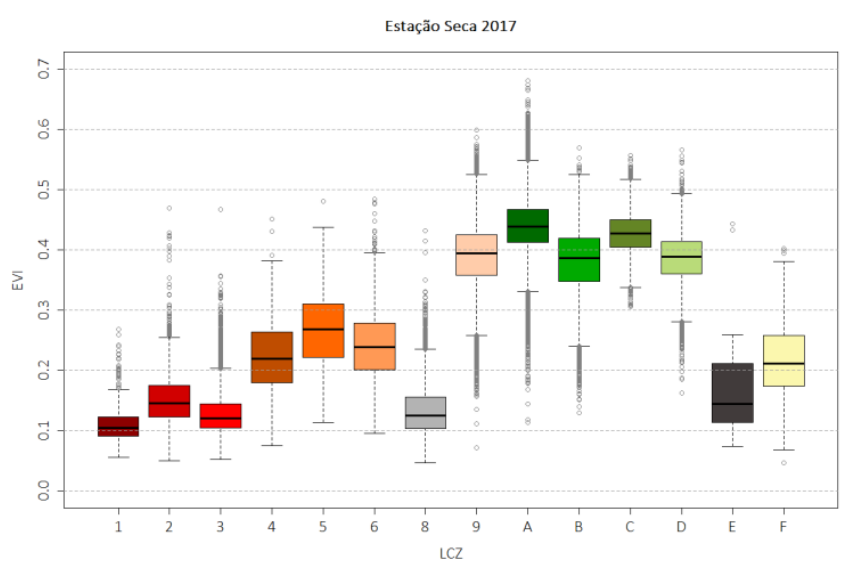

Figura 85. EVI por LCZ 2017 Estação Seca 2017. 
Os resultados dos índices de vegetação por LCZ são consistentes com a quantidade de vegetação esperada para cada classe, ou seja, LCZ construídas apresentam índices de vegetação menores que as LCZ não construídas e as LCZ construídas compactas apresentam índices de vegetação inferiores às LCZ construídas abertas, sendo possível, de forma geral, distinguir as classes por seus valores de NDVI e EVI.

A divisão entre as classes é mais clara nos resultados do NDVI, incluindo as classes de vegetação. A LCZ A (Vegetação arbórea densa) apresenta valores superiores em relação às demais classes vegetadas. Esta divisão não se apresenta tão clara nos resultados de EVI, sendo os valores para a LCZ A (Vegetação arbórea densa) próximos aos valores da LCZ C (Vegetação arbustiva).

Algumas inconsistências podem ser verificadas nas classes menos presentes na RMSP. Para o ano de 2002, por exemplo, nota-se que a classe 2 (Médio-compacto) apresenta índices de vegetação próximos aos da classe 4 (Alto-aberto). Possivelmente isso ocorre por conta de equívocos na classificação LCZ; porém, sendo a classe 2 pouco frequente na RMSP, tal inconsistência não compromete a análise das demais classes.

\subsubsection{Temperatura e índices de vegetação}

As temperaturas médias por estação seca e chuvosa foram confrontadas com os índices de vegetação médios por estação para todos os anos de análise, utilizando-se imagens com resolução espacial de $1 \mathrm{~km}$ e de $250 \mathrm{~m}$ e considerando-se todas as imagens ou apenas aquelas com mais de $50 \%$ de dados válidos, conforme descrito no item 3.1. Foram elaborados gráficos de dispersão, e calculados o correspondente coeficiente de determinação, para as 30 estações analisadas (estação chuvosa 2002/2003 a estação seca 2017) com o objetivo de verificar tanto a natureza da relação entre $T_{\text {sup }}$ e vegetação quanto se tal relação apresentou alteração durante o período de análise. A Figura 86 exemplifica os resultados encontrados para a estação chuvosa de 2002/2003. 

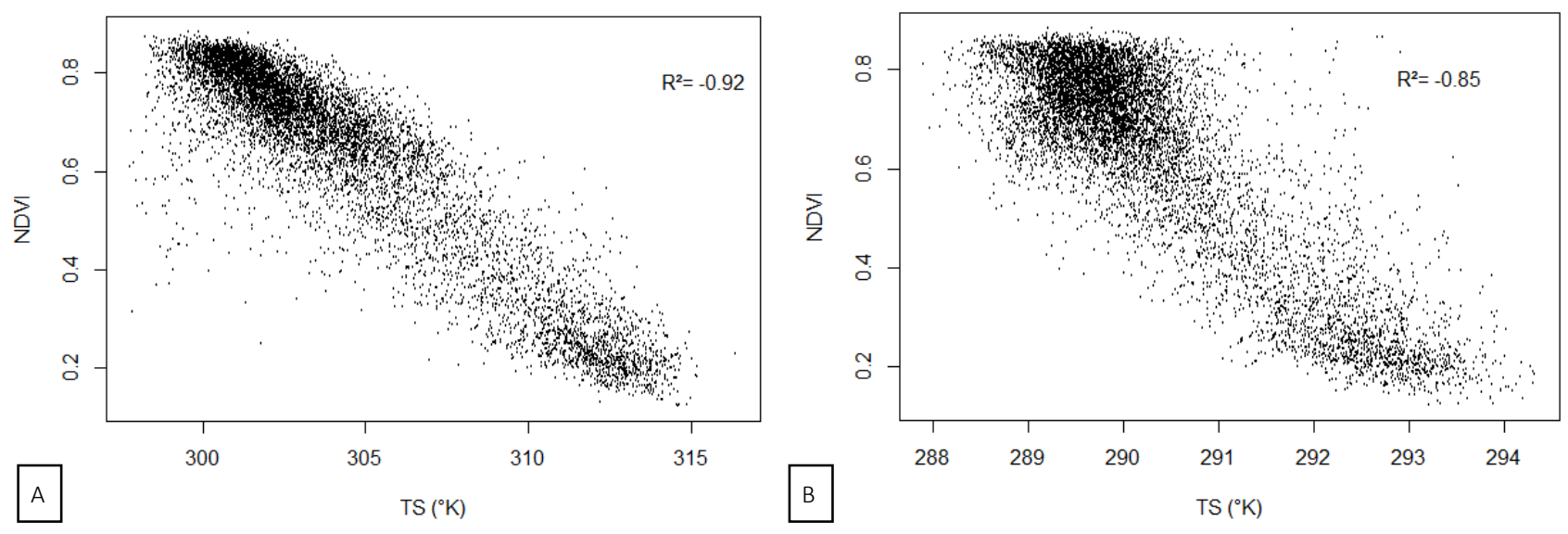

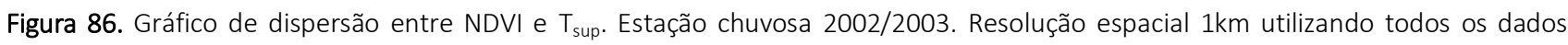
disponíveis. A) Temperatura superficial diurna. B) Temperatura superficial noturna.

Em todas as estações verificou-se forte correlação negativa ente vegetação e $T_{\text {sup. }} A$ correlação é maior com os dados de $1 \mathrm{~km}$, com as temperaturas de superfície diurnas e com o NDVI. As menores correlações verificadas entre as quatro variáveis foram:

Para imagens com resolução de $1 \mathrm{~km}$ :

- $\quad T_{\text {sup }}$ diurna e NDVI: $r^{2}=0,9$

- $\quad T_{\text {sup }}$ diurna e EVI: $r^{2}=0,82$

- $\quad T_{\text {sup }}$ noturna e NDVI: $r^{2}=0,59$

- $\quad T_{\text {sup }}$ noturna e EVI: $r^{2}=0,63$

Para imagens com resolução de 250m:

- $\quad T_{\text {sup }}$ diurna e NDVI: $r^{2}=0,88$

- $\quad T_{\text {sup }}$ diurna e EVI: $r^{2}=0,79$

- $\quad T_{\text {sup }}$ noturna e NDVI: $r^{2}=0,56$

- $\quad T_{\text {sup }}$ noturna e EVI: $r^{2}=0,59$

A tabela completa com todas as correlações encontra-se no Apêndice 2.

Adicionalmente, foi examinado se a alta correlação entre os índices de vegetação e as temperaturas superficiais sofria alteração em anos mais quentes. A Figura 87 e a Figura 88 apresentam a variação da correlação ao longo do tempo e a $T_{\text {sup }}$ média da RMSP. 


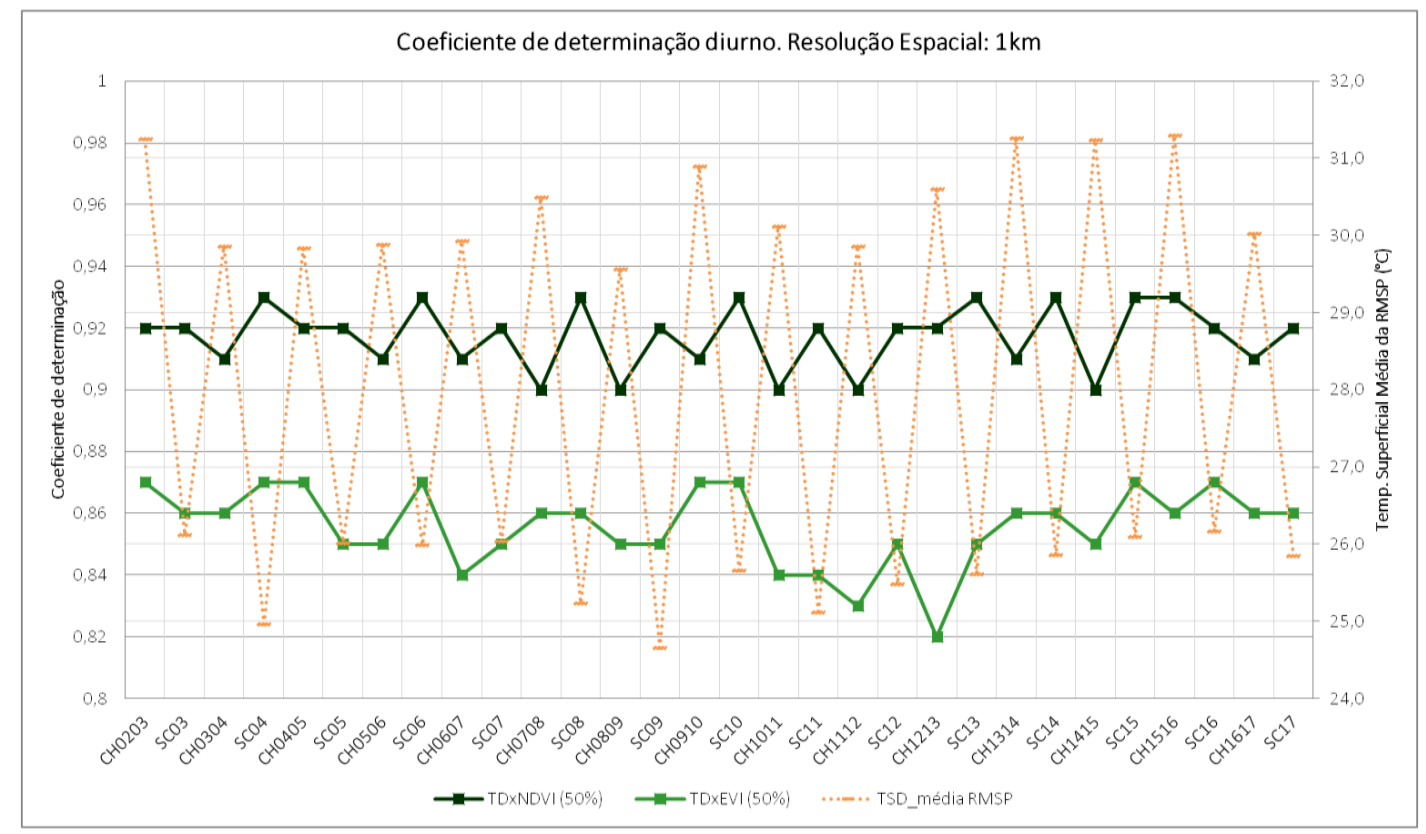

Figura 87. Coeficientes de determinação entre $T_{\text {sup }}$ diurna e NDVI/EVI.

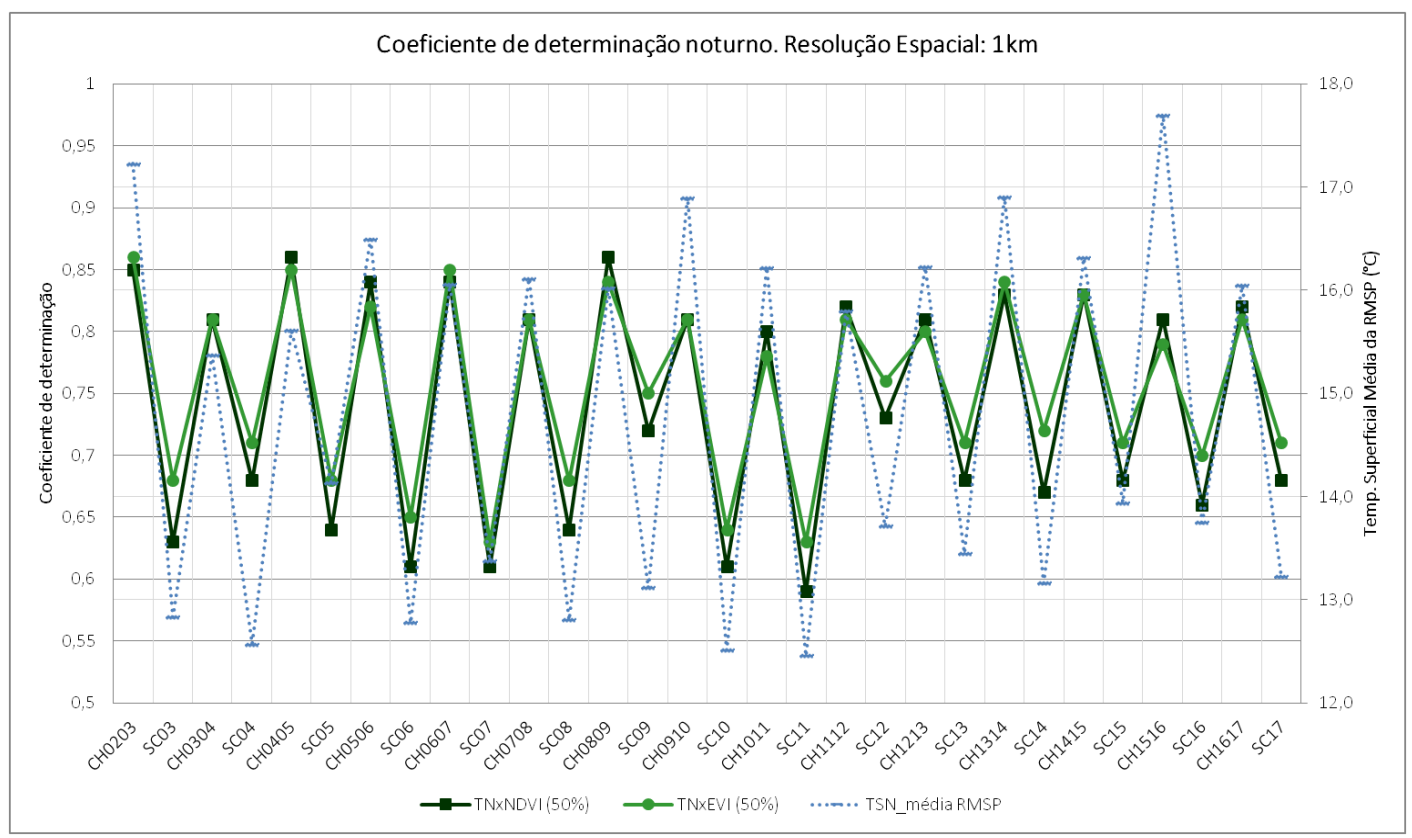

Figura 88. Coeficientes de determinação entre $T_{\text {sup }}$ noturna e NDVI/EVI.

Os resultados mostram certa sazonalidade da correlação, porém, não indicam haver alteração da correlação em anos de maior $T_{\text {sup }}$ média, assinalando estabilidade da relação 
entre vegetação e $T_{\text {sup. }}$. Destaca-se que as diferenças entre as correlações do NDVI e EVI são maiores para o período diurno e que a correlação nas estações secas é, em diversos casos, superior à estação chuvosa, possivelmente devido à maior quantidade de dados disponíveis nessa estação.

\subsection{Caracterização temporal}

\subsubsection{Morfologia Urbana}

A partir dos mapas de morfologia urbana desenvolvidos para os anos de 2002, 2010 e 2017, foram realizadas análises de detecção de mudança entre os intervalos 2002 a 2010, 2010 a 2017 e 2002 a 2017.

As alterações morfológicas foram examinadas por meio de comparação entre os mapas, de acordo com o método descrito no item 3.4 O principal objetivo das análises de detecção de mudança foi examinar supressões e ganhos de vegetação que pudessem ajudar a compreender alterações de $\mathrm{T}_{\text {sup }}$ ou dos índices de vegetação.

\section{Alterações de vegetação}

A Figura 89, a Figura 93 e a Figura 97 apresentam as alterações de vegetação entre 2002 e 2010, 2010 e 2017 e 2002 e 2017, respectivamente. O mapa que abrange todo o intervalo temporal (2002-2017) não se configura como a soma dos outros dois mapas. Conforme será discutido nesse item, áreas de cultivo de eucalipto, por exemplo, podem apresentar supressão de vegetação no mapa 2002-2010, ganho de vegetação no mapa 2010-2017 e nenhuma alteração no mapa 2002-2017. As alterações captadas estão, portanto, vinculadas ao intervalo temporal analisado. É importante ressaltar ainda que as imagens de alta resolução utilizadas nesse estudo como sendo a "verdade terrestre" foram obtidas com pequeno intervalo temporal em relação às cenas do satélite Landsat usadas para gerar os mapas LCZ. Assim, classificações imprecisas ou confusões na classificação podem, na verdade, advir dessa pequena diferença temporal na aquisição das imagens, principalmente no caso das culturas agrícolas. 


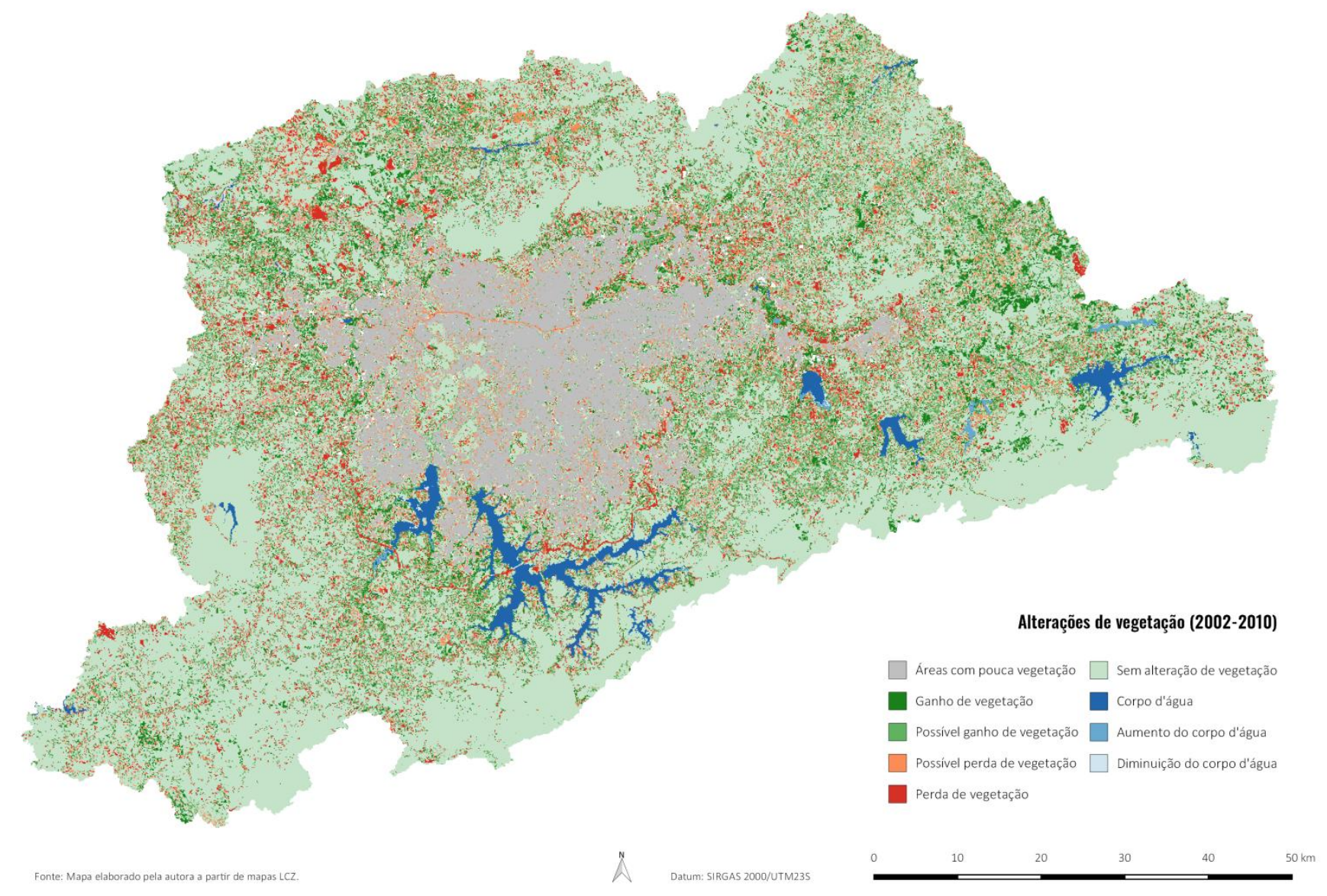

Figura 89. Alterações de vegetação entre 2002 e 2010. Fonte: elaboração própria a partir de mapas LCZ.

Dada a impossibilidade de se discutir cada uma das alterações verificadas nos mapas de detecção de mudanças de forma particularizada, optou-se por destacar algumas áreas e evidenciar, por meio de comparação com as imagens de alta resolução, as alterações observadas. De maneira geral, as áreas com ganho de vegetação na área periférica da RMSP são áreas de cultura agrícola ou florestal. Ganhos e perdas de vegetação nessas áreas relacionam-se principalmente com a sazonalidade das culturas. Nas áreas mais próximas à área urbana principal as perdas de vegetação devem-se, sobretudo, à abertura de novos loteamentos ou à execução de grandes obras, como galpões ou obras viárias como o Rodoanel. A Figura 90 a Figura 92 apresentam exemplos das alterações mencionadas ocorridas entre 2002 e 2010, tais como áreas com ganho de vegetação no município de Guararema, mostrada na Figura 90. 

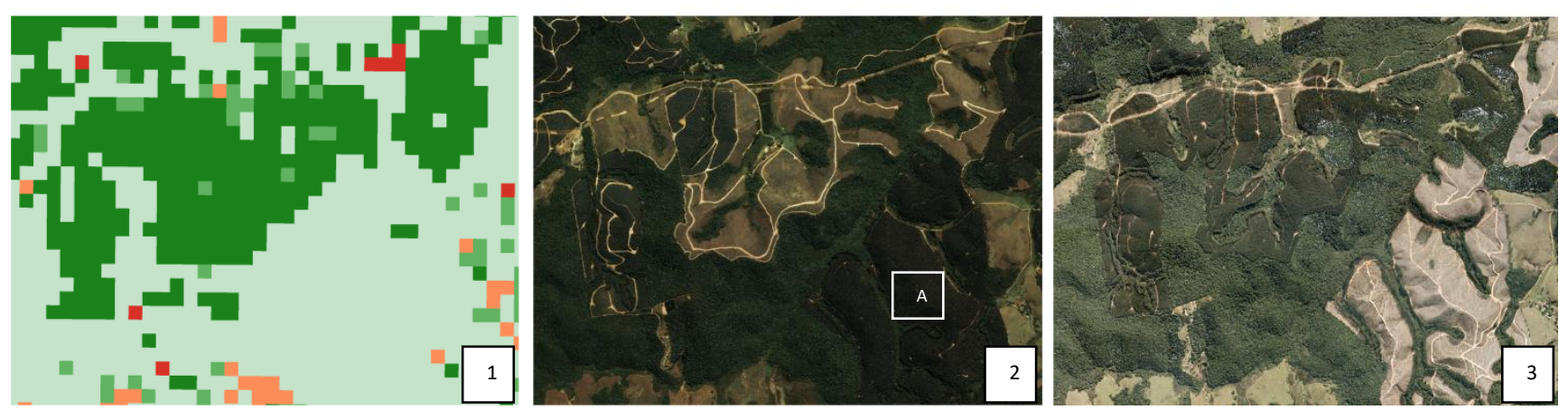

Figura 90. Ganho de vegetação entre 2002 e 2010 em Guararema. 1) Mapa de detecção de mudanças. 2) Imagem IKONOS 2002. 3) Ortofoto 2010/2011. Fonte: 1) Elaboração própria. 2 ) IG (2002). 3) EMPLASA (2010).

As áreas desmatadas observadas na Figura 90.2 A não aparecem no mapa de detecção de mudanças, pois a ortofoto 2010/2011 foi adquirida após a cena Landsat usada na produção do mapa. Esta área aparece como área desmatada nos mapas 2010-2017 e 2002-2017.

Na Figura 91, que mostra parte dos municípios de Cajamar e Caieiras, é possível verificar que as áreas com perda de vegetação apresentam-se mais concentradas do que as áreas com ganho de vegetação, mais dispersas.
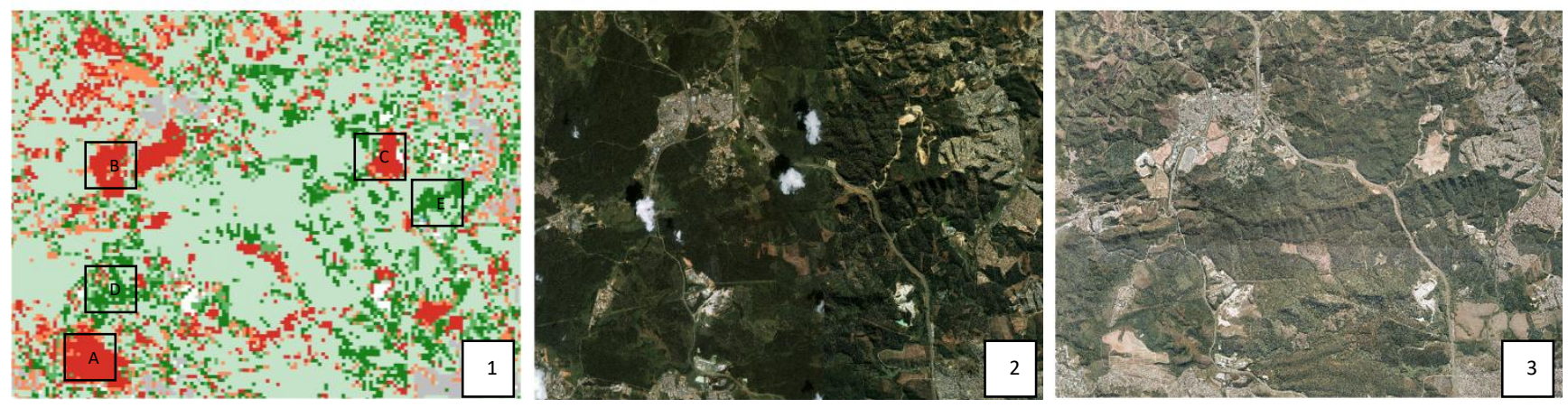

Figura 91. Perda de vegetação entre 2002 e 2010 em Cajamar e Caieiras. 1) Mapa de detecção de mudanças. 2) Imagem IKONOS 2002. 3) Ortofoto 2010/2011. Fonte: 1) Elaboração própria. 2 ) IG (2002). 3) EMPLASA (2010).

As maiores supressões de vegetação verificadas na Figura 91 deveram-se à implantação de loteamentos residenciais (Figura $91.1 \mathrm{~A}$ ), área industrial próxima à Rodovia Anhanguera (Figura 91.1 B), e expansão de aterro sanitário (Figura 91.1 C). Já os ganhos, mais dispersos do que as perdas, ocorreram sobretudo em áreas de cultivo de eucalipto (Figura 91.1 D e E, por exemplo). 
As alterações ocorridas próximas ao trecho sul do Rodoanel Mário Covas, zona sul do município de São Paulo, podem ser vistas na Figura 92. O delineamento da via visto com clareza na Figura 92.1 não o é nos mapas de LCZ de 2010 ou 2017 (Figura 42 e Figura 45), evidenciando como o agrupamento de classes realizado nos mapas de detecção de mudanças pode complementar as informações dos mapas de LCZ, minimizando suas incertezas e permitindo a identificação de alterações que não seriam passíveis de serem identificadas apenas pela comparação visual dos mapas.
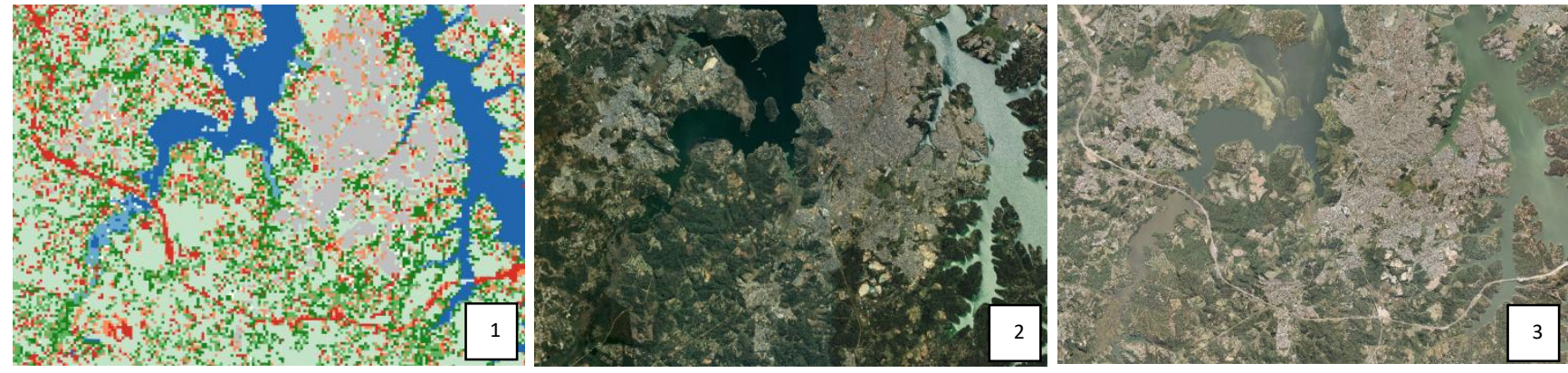

Figura 92. Alterações de vegetação entre 2002 e 2010 na zona sul de São Paulo. 1) Mapa de detecção de mudanças. 2) Imagem IKONOS 2002. 3) Ortofoto 2010/2011. Fonte: 1) Elaboração própria. 2) IG (2002). 3) EMPLASA (2010).

As alterações verificadas entre 2010 e 2017 (Figura 93) apresentam características semelhantes àquelas verificadas entre 2002 e 2010, com destaque para as regiões de Caieiras e Cajamar, na porção nordeste da RMSP, para a implantação dos trechos leste/norte do Rodoanel Mario Covas e para a região de Guararema, leste da RMSP. 


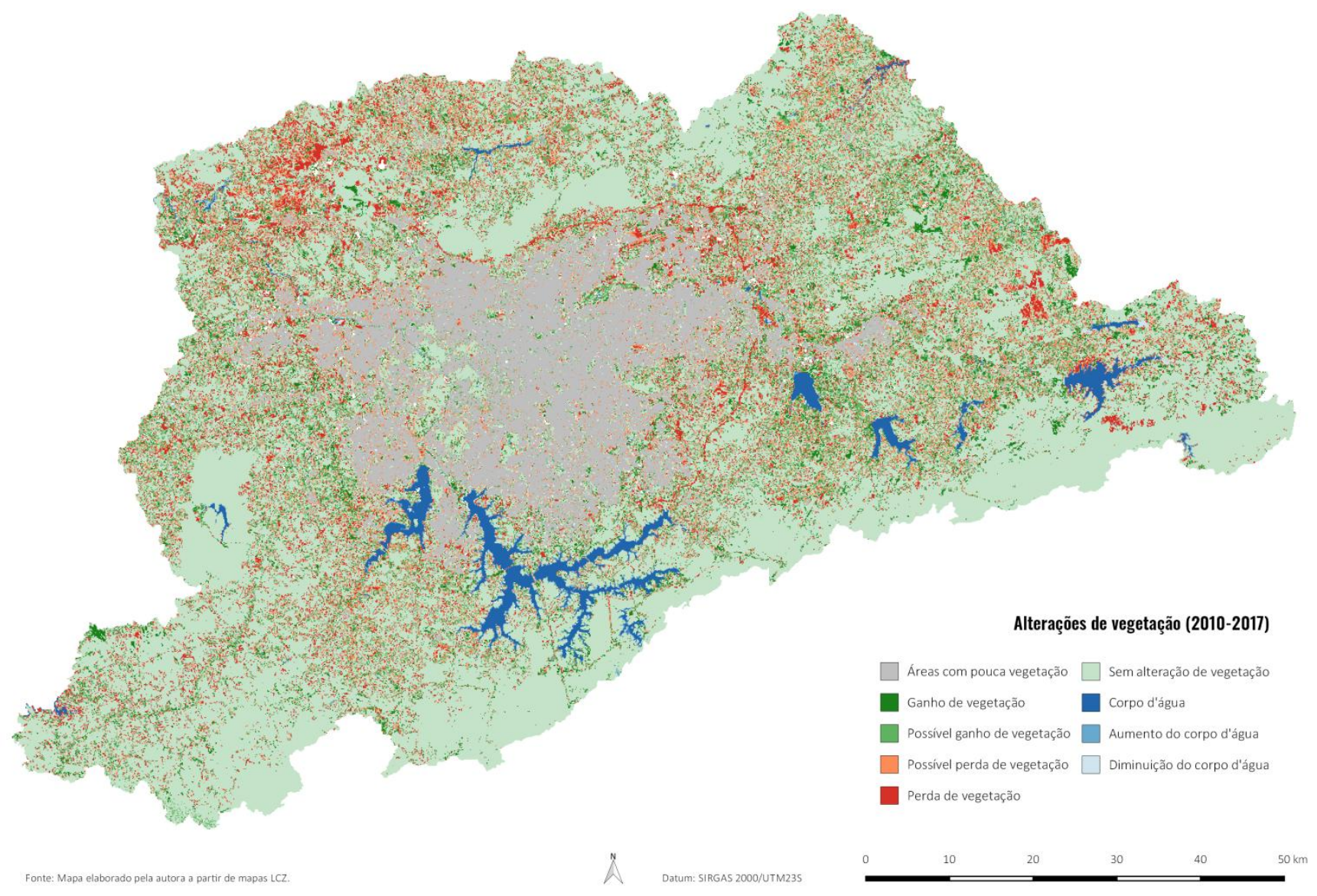

Figura 93. Alterações de vegetação entre 2010 e 2017. Fonte: elaboração própria a partir de mapas LCZ.

Na região de Cajamar verificaram-se alterações devido à expansão de áreas industriais

(Figura 94).
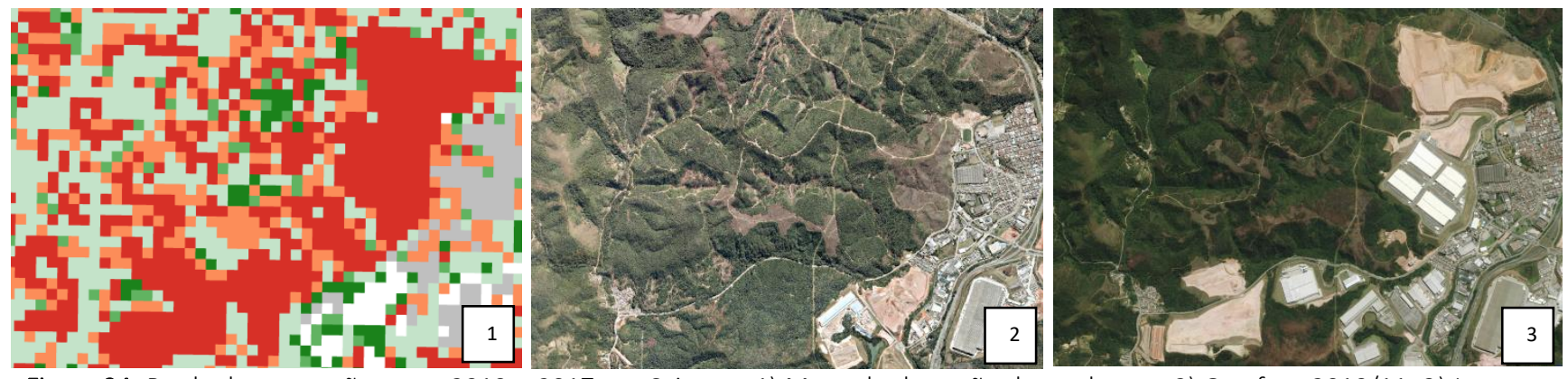

Figura 94. Perda de vegetação entre 2010 e 2017 em Cajamar. 1) Mapa de detecção de mudanças. 2) Ortofoto 2010/11. 3) Imagem Google Earth 2017. Fonte: 1) Elaboração própria. 2) EMPLASA (2010). 3) Google (2018). 
Em Guararema (Figura 95), região leste da RMSP, as dinâmicas das áreas de cultivo de eucalipto foram responsáveis pelas áreas de alteração mais extensas.
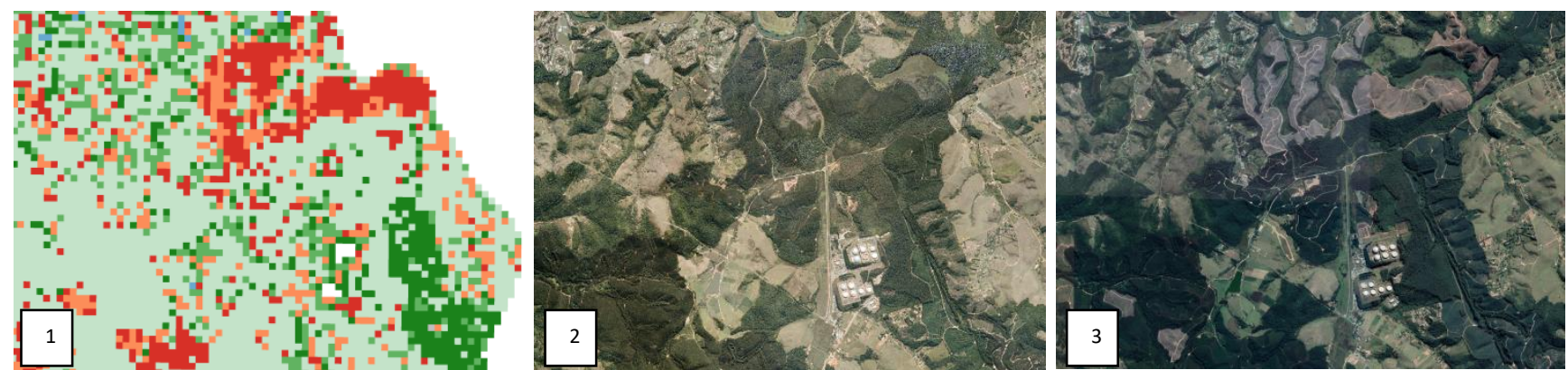

Figura 95. Alterações de vegetação entre 2010 e 2017 em Guararema. 1) Mapa de deteç̧̃a de mudanças. 2) Ortofoto 2010/11. 3) Imagem Google Earth 2017. Fonte: 1) Elaboração própria. 2) EMPLASA (2010). 3) Google (2018).

A Figura 96 mostra um dos trechos do Rodoanel Mario Covas executado no período 20102017 na região de Guarulhos e Arujá. Nessa área mais urbanizada é possível verificar alterações da vegetação em decorrência da execução de grandes equipamentos, como a ampliação do aeroporto internacional de Guarulhos (Figura 96 1A) ou a implantação de galpões (Figura 96 1B), além de áreas de expansão urbana (Figura 96 1C).
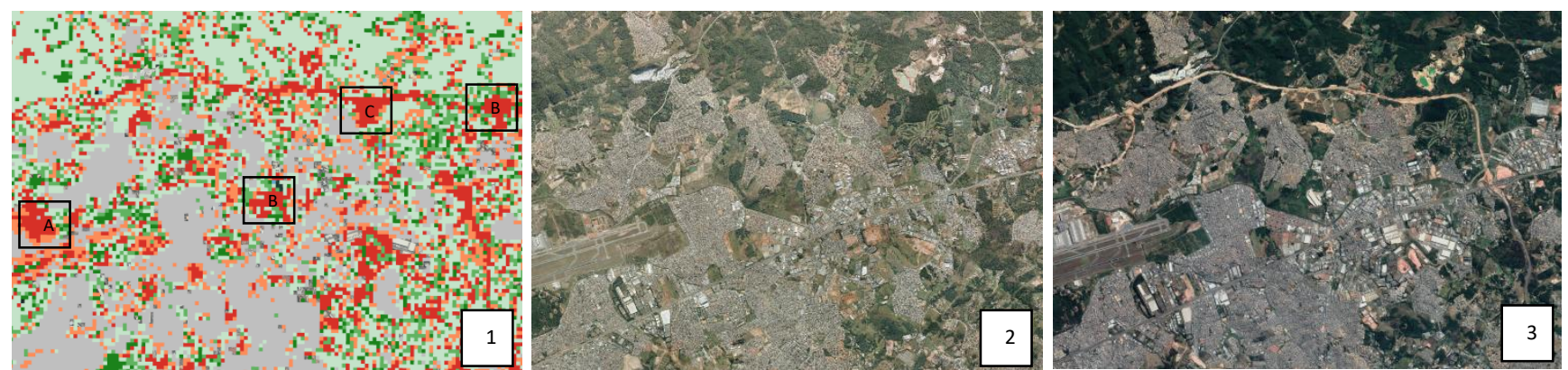

Figura 96. Alterações de vegetação entre 2010 e 2017 em Guarulhos e Arujá. 1) Mapa de detecção de mudanças. 2) Ortofoto 2010/11. 3) Imagem Google Earth 2017. Fonte: 1) Elaboração própria. 2) EMPLASA (2010). 3) Google (2018).

A Figura 97 apresenta o mapa de alterações da vegetação verificadas entre 2002 e 2017. Como mencionado anteriormente não se trata da soma dos mapas anteriores, visto que algumas alterações podem ser sazonais, como aquelas verificadas nas áreas de cultivo de eucalipto. 


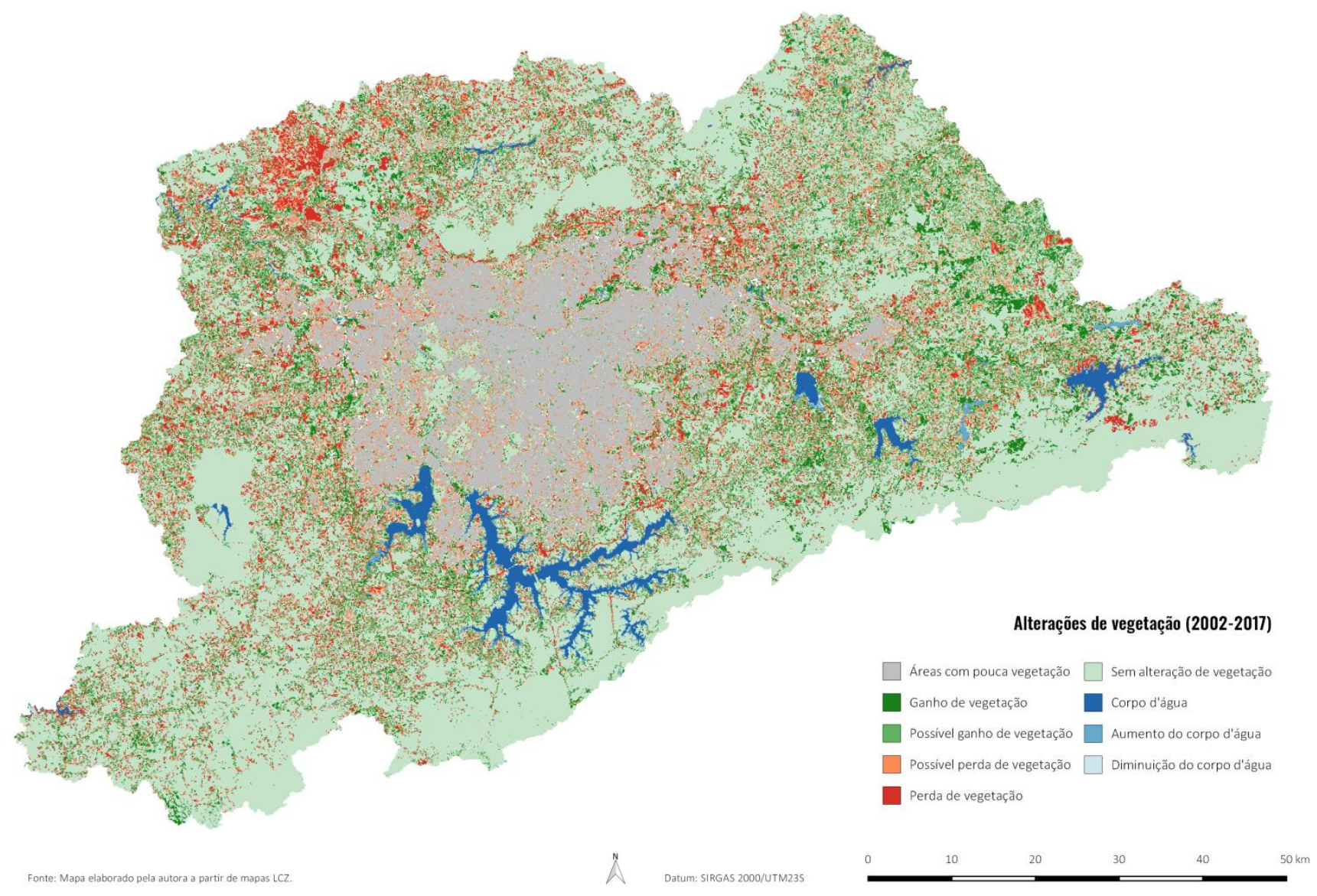

Figura 97. Alterações de vegetação entre 2002 e 2017. Fonte: elaboração própria a partir de mapas LCZ. 


\subsubsection{Temperatura de superfície}

Conforme descrito no item 3.4 do presente trabalho, foram realizadas análises de tendência para as quatro variáveis estudadas com o objetivo de identificar quais pixels apresentaram aumento ou redução dos valores no período estudado. Para cada pixel foi realizado o ajuste da reta de regressão linear e consideradas a significância estatística (intervalo de confiança de 95\%) e prática (alterações significativas são aquelas superiores a $\left.0,5^{\circ} \mathrm{C}\right)$ das variáveis. Os resultados das análises de tendência das temperaturas superficiais são apresentados na resolução espacial de $1 \mathrm{~km}$, sendo divididos em três tipos de mapas. O primeiro identifica se houve ou não alteração significativa (Figura 101), o segundo identifica a magnitude da alteração (Figura 102) e, o terceiro, o ano de ocorrência da primeira alteração significativa (Figura 103 e Figura 104).

A importância do tratamento estatístico dos dados pode ser verificada por meio da comparação dos mapas com e sem tratamento. A Figura 98 apresenta o resultado da análise de tendência para a $T_{\text {sup }}$ diurna sem significância estatística ou significância prática. A Figura 99 apresenta o mesmo mapa, porém apenas com informações com significância estatística, e a Figura 100 adiciona a significância prática. Em vermelho, áreas com tendência positiva (aumento) e em azul, tendência negativa (redução). É possível se verificar que a interpretação dos resultados seria equivocada caso o tratamento estatístico não fosse realizado. Já a necessidade de definição da significância prática dependerá da variável analisada, da acurácia do sensor utilizado e do objetivo da pesquisa.

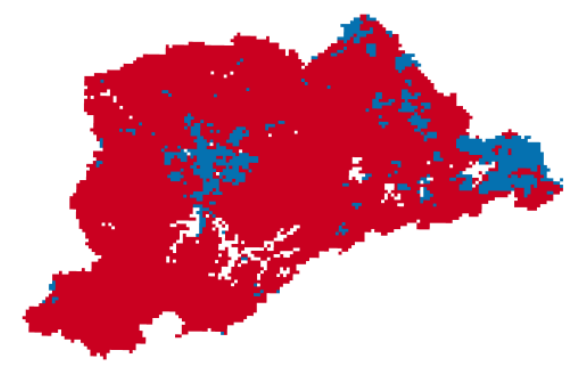

Figura 98. Análise de tendência da $T_{\text {sup }}$ diurna. Sem significância estatística ou prática.

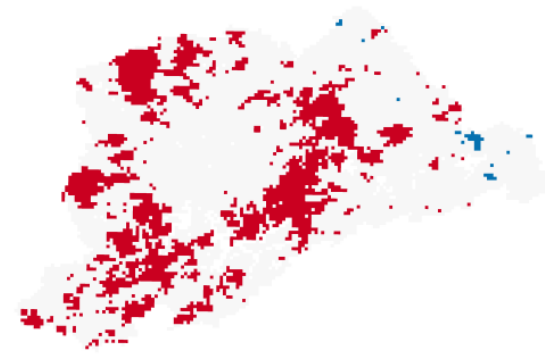

Figura 99. Análise de tendência da $T_{\text {sup }}$ diurna. Com significância estatística, sem significância prática.

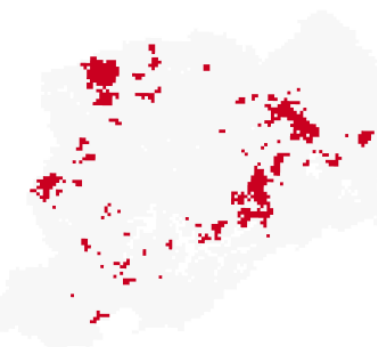

Figura 100. Análise de tendência da $T_{\text {sup }}$ diurna. Com significância estatística e significância prática. 


\section{Temperatura superficial diurna}

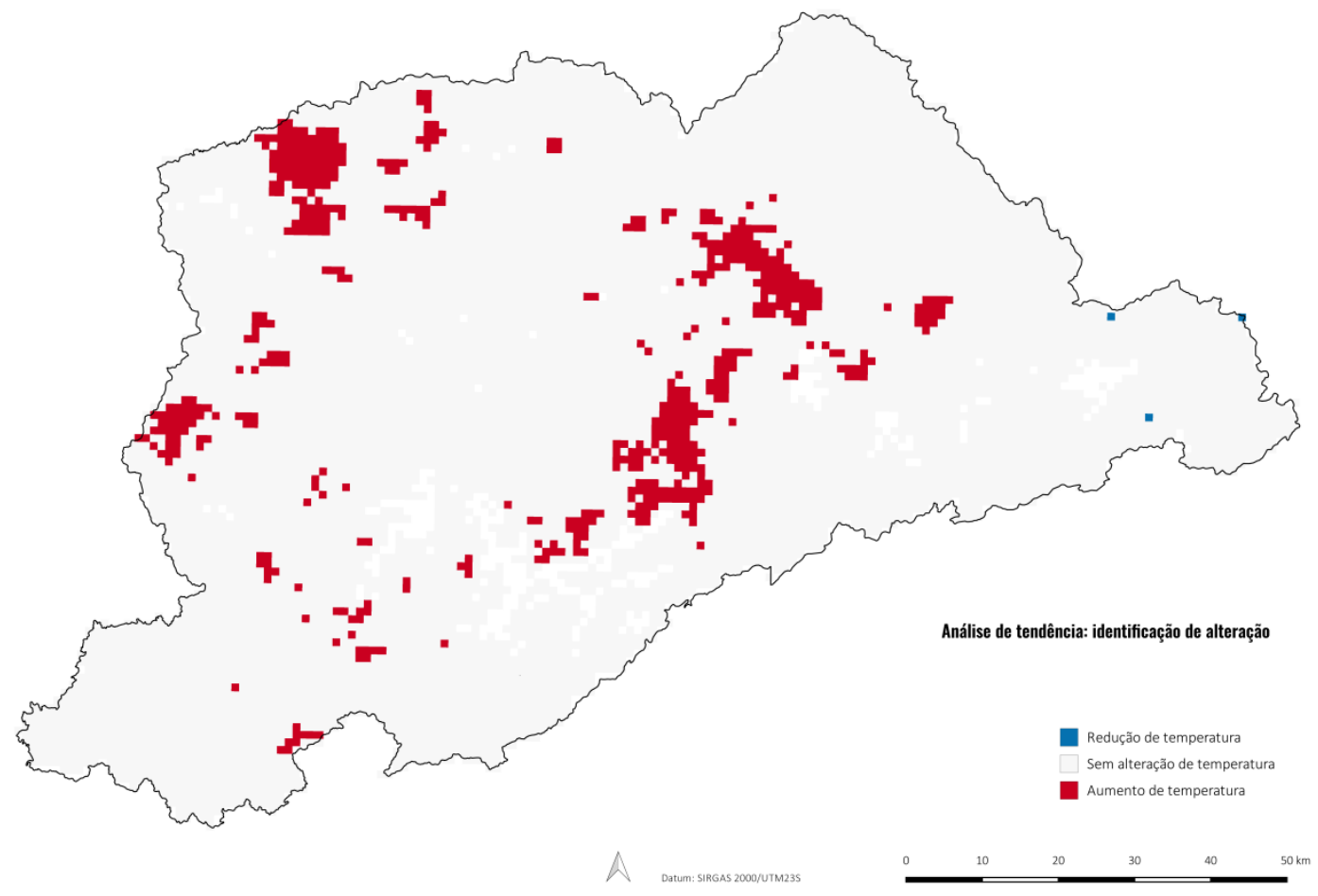

Figura 101. Identificação de tendência. $T_{\text {sup }}$ diurna. Identificação de alteração.

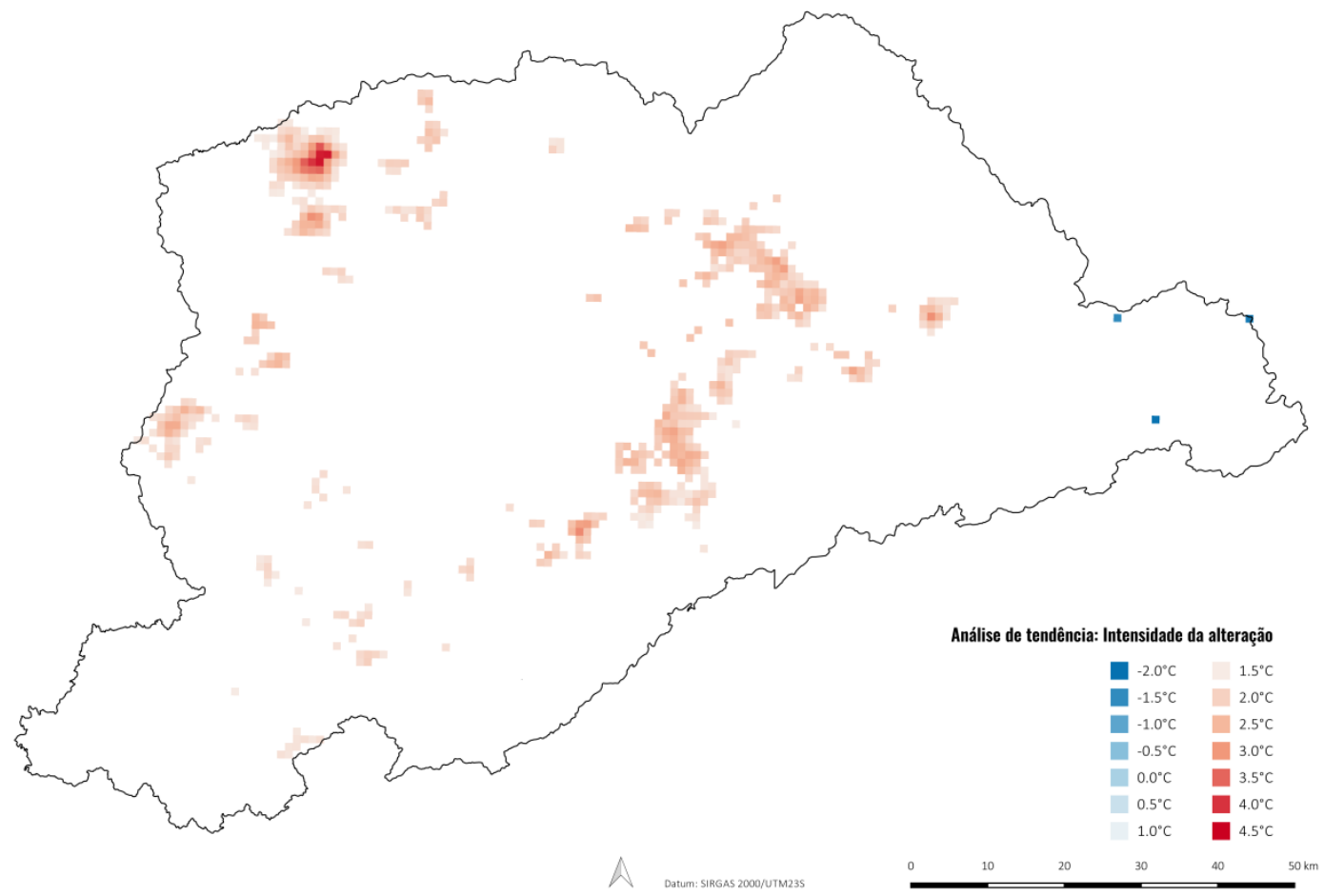

Figura 102. Identificação de tendência. $T_{\text {sup }}$ diurna. Intensidade da alteração. 


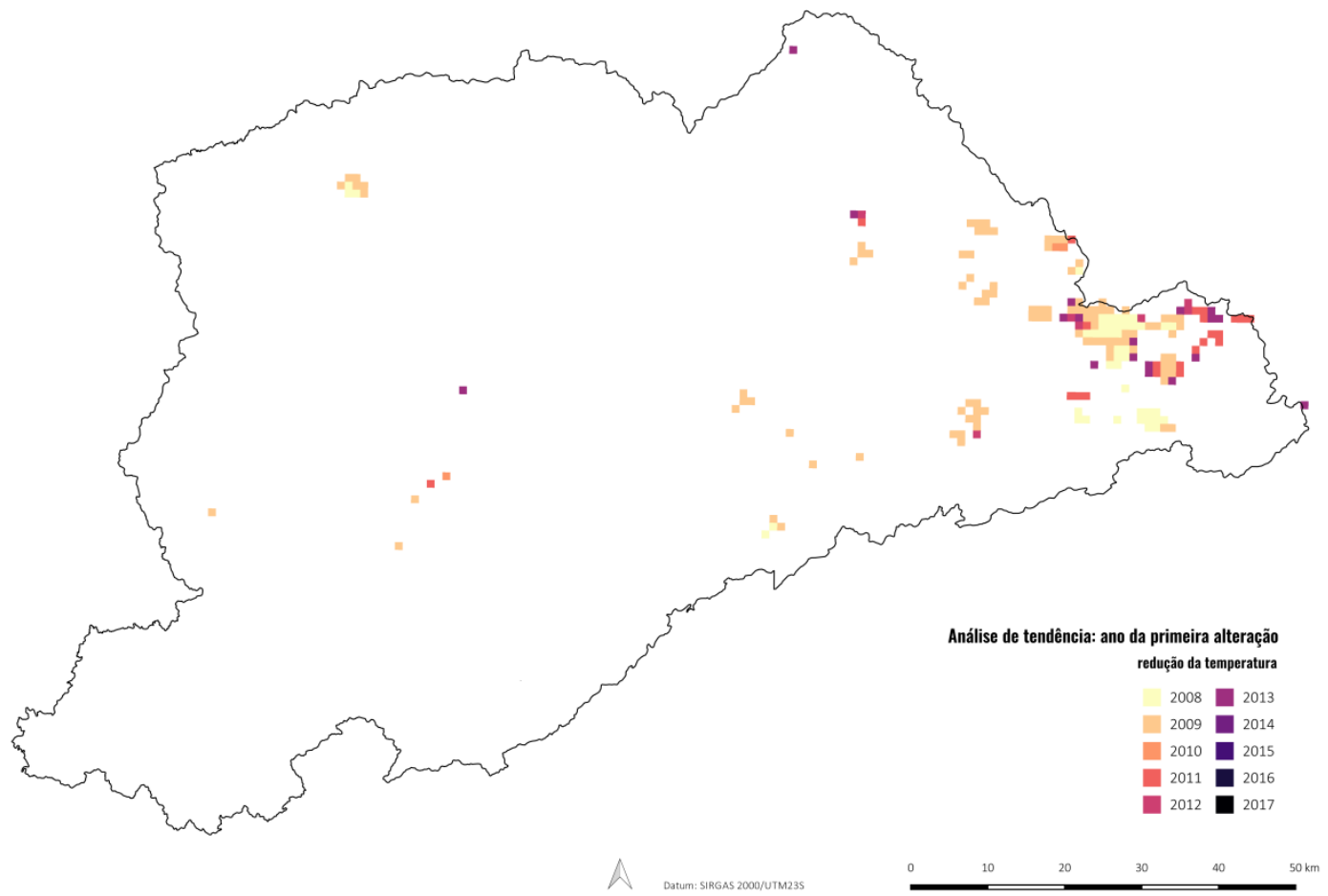

Figura 103. Identificação de tendência. $T_{\text {sup }}$ diurna. Ano de alteração. Redução.

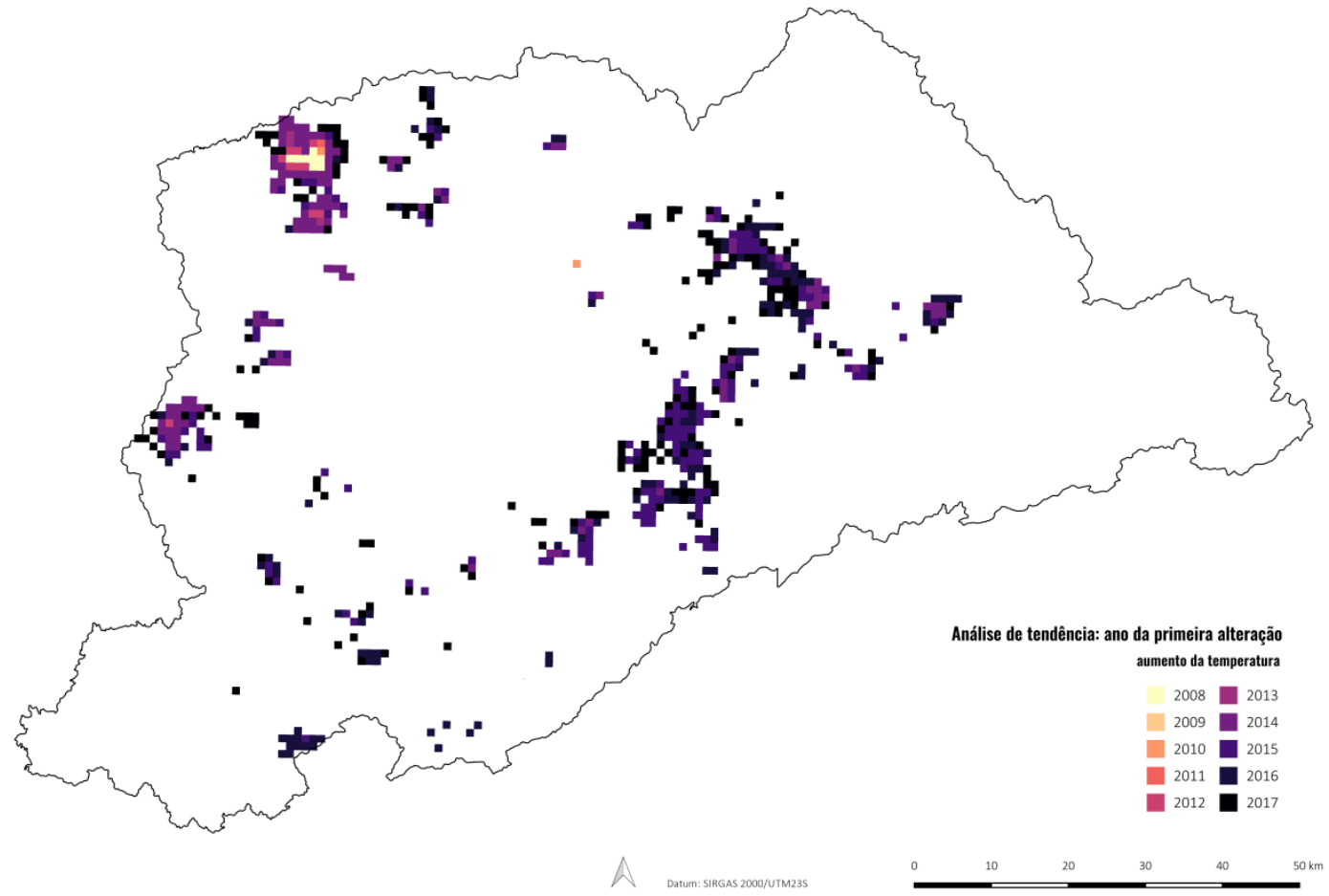

Figura 104. Identificação de tendência. $T_{\text {sup }}$ diurna. Ano de alteração. Aumento. 
A região urbana periférica concentra as maiores alterações do período, sendo que a maioria das alterações é recente e ocorreu por aumento de temperatura.

A Figura 103 e a Figura 104 apresentam o ano da primeira mudança significativa, ou seja, uma análise de tendência com diferentes intervalos temporais. Por esse motivo contêm mais pixels do que a Figura 101, que apresenta a análise de tendência para todo o período de estudo. A porção sudeste da RMSP, que aparece na Figura 103 como tendo verificado redução da $T_{\text {sup }}$ diurna entre 2003 e 2008/2009, não apresentou a mesma redução considerando-se todo o intervalo temporal, evidenciando a ocorrência de alteração pontual significativa para um pequeno intervalo temporal mas não significativa para todo o intervalo.

A observação individual de cada área, com imagens de alta resolução do ano de ocorrência da mudança, é necessária para explicar quais alterações ocorreram. Dada a indisponibilidade de imagens de alta resolução de todos os anos analisados, algumas áreas foram escolhidas para maior detalhamento.

A Figura 105 e a Figura 106 mostram as áreas que verificaram redução significativa da $T_{\text {sup }}$ diurna na porção sudeste da RMSP sobre imagens de alta resolução de 2002 e 2010, respectivamente. O aumento da quantidade de água na Barragem do Rio Paraitinga, em Salesópolis, pode explicar a redução de temperatura diurna.

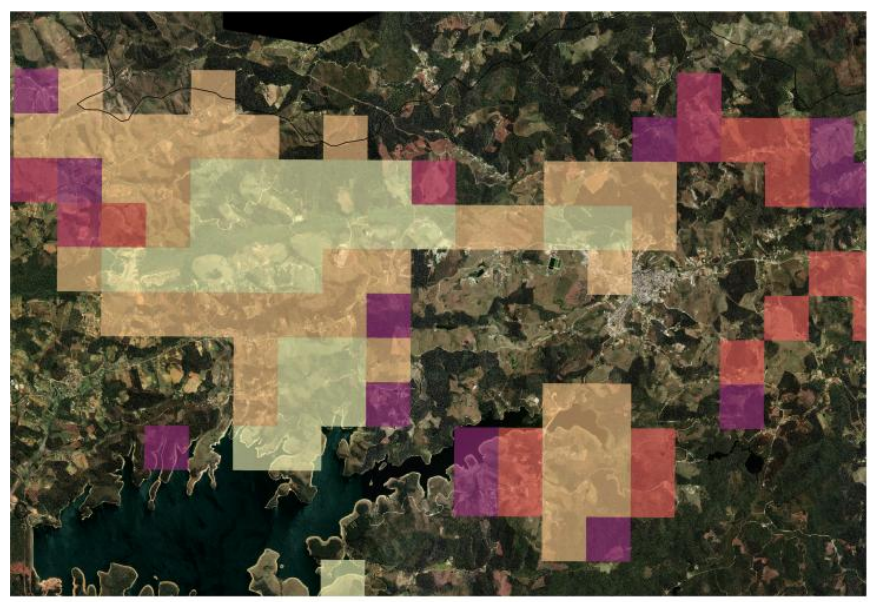

Figura 105. Área com redução significativa de $T_{\text {sup }}$ diurna entre 2003 a 2008/2012 sobre imagem IKONOS de 2002 (IG, 2002). Salesópolis.

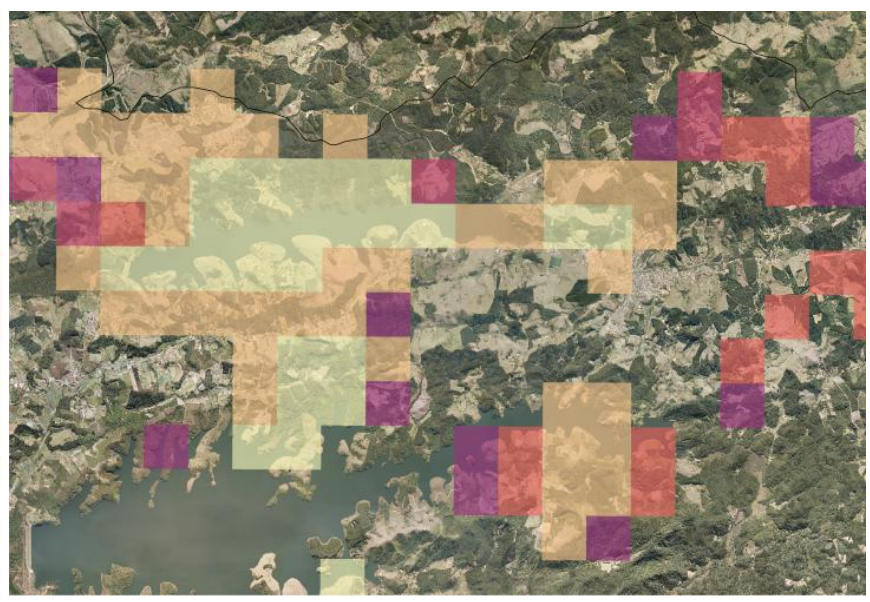

Figura 106. Área com redução significativa de $T_{\text {sup }}$ diurna entre 2003 a 2008/2012 sobre ortofoto 2010 (EMPLASA, 2010). Salesópolis. 
A Figura 107 e a Figura 108 mostram, respectivamente, áreas com aumento de temperatura nos municípios de Itaquaquecetuba e em Ferraz de Vasconcelos (na divisa com São Paulo). As duas áreas verificaram alterações semelhantes: adensamento das áreas já urbanizadas, expansão das áreas ocupadas sobre áreas naturais, implantação de pavimentação asfáltica e, no caso de Itaquaquecetuba, implantação de trecho do Rodoanel Mário Covas. O conjunto de todas essas intervenções acarretou a tendência positiva para a $\mathrm{T}_{\text {sup }}$ diurna, sendo a supressão da vegetação captada nos mapas de detecção de mudança.
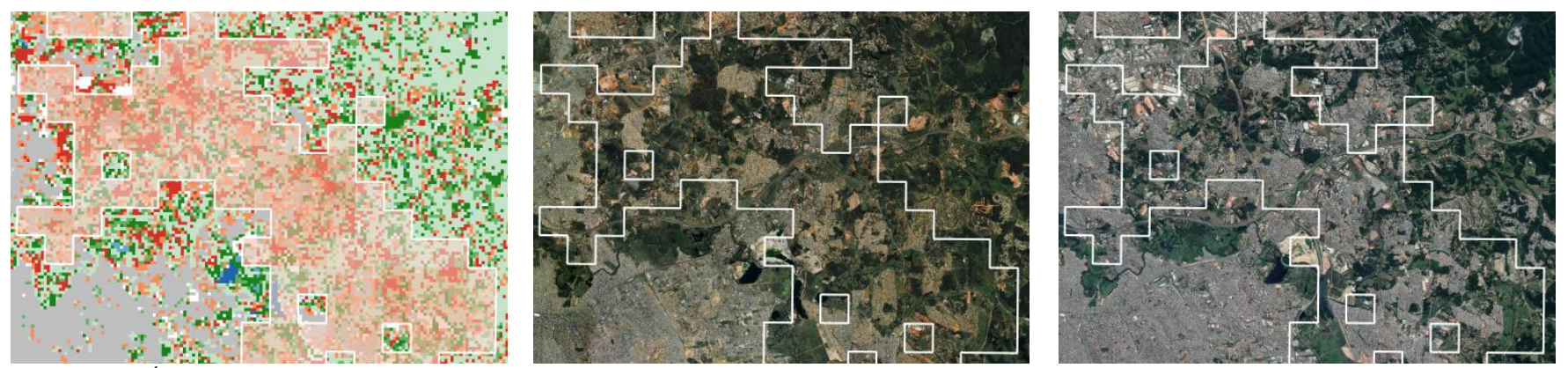

Figura 107. Área com aumento significativo de $T_{\text {sup }}$ diurna na região de Itaquaquecetuba. 1) Mapa de detecção de mudança. 2) Imagem IKONOS 2002. 3) Imagem Google Earth 2017. Fonte: 1) Elaboração própria. 2) IG (2002). 3) Google (2018).
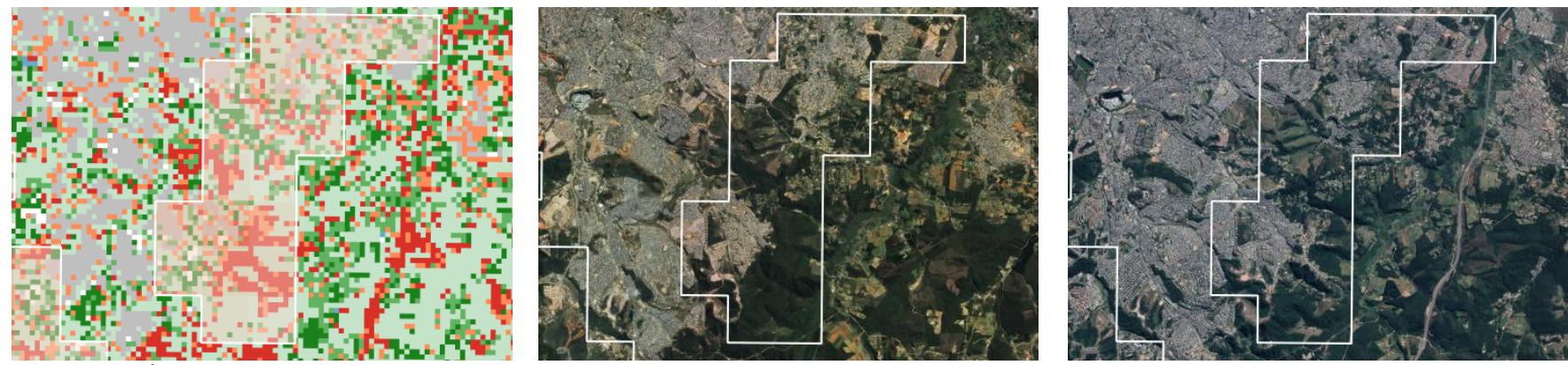

Figura 108. Área com aumento significativo de $T_{\text {sup }}$ em Ferraz de Vasconcelos. 1) Mapa de deteç̧ão de mudança. 2) Imagem IKONOS 2002. 3) Imagem Google Earth 2017. Fonte: 1) Elaboração própria. 2) IG (2002). 3) Google (2018).

Aumentos significativos de $T_{\text {sup }}$ também foram verificados na região de Vargem Grande Paulista e Cotia, extremo Oeste da RMSP (Figura 109) e em Cajamar (Figura 110), norte da RMSP. No primeiro caso verifica-se a expansão de loteamentos residenciais e a implantação de pavimentação asfáltica. No segundo caso a implantação de grandes galpões industriais próximos à Rodovia Anhanguera, com a supressão de vegetação arbórea densa, provocou o maior aumento de $\mathrm{T}_{\text {sup }}$ diurna verificado na RMSP. 

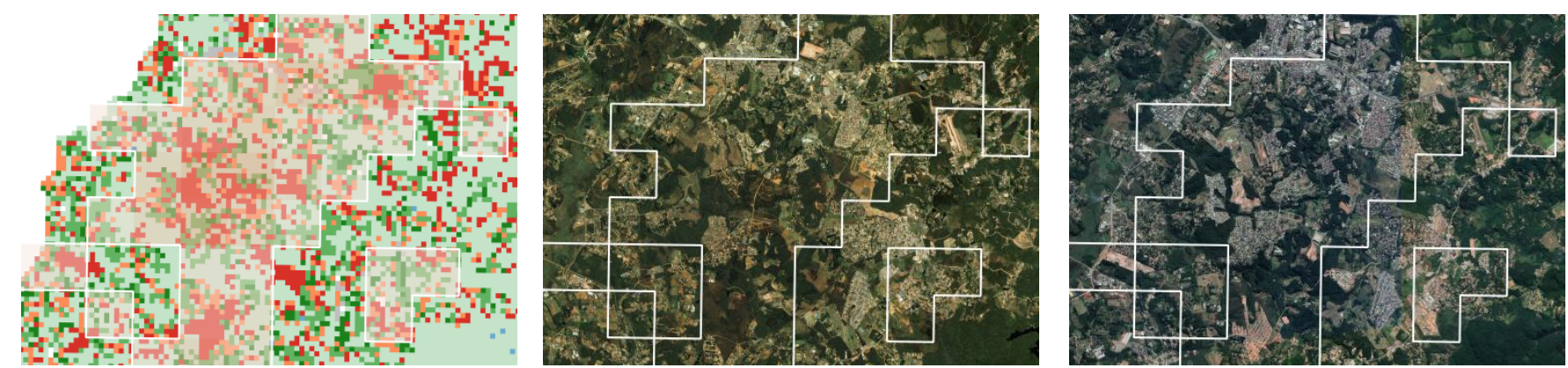

Figura 109. Área com aumento significativo de $T_{\text {sup }}$ diurna na região de Vargem Grande Paulista e Cotia. 1) Mapa de detecção de mudança.

2) Imagem IKONOS 2002. 3) Imagem Google Earth 2017. Fonte: 1) Elaboração própria. 2) IG (2002). 3) Google (2018).
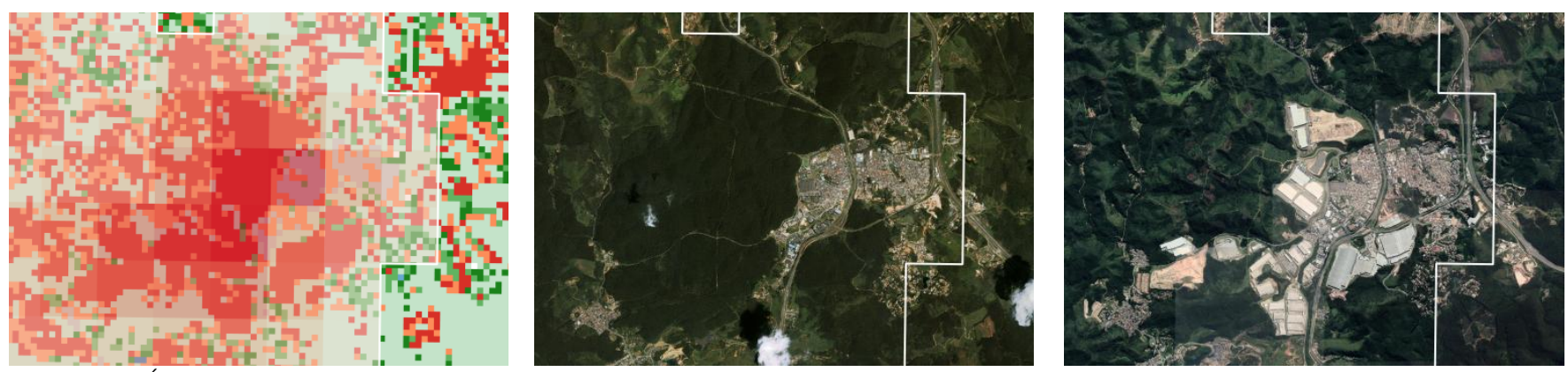

Figura 110. Área com aumento significativo de $T_{\text {sup }}$ em Cajamar. 1) Mapa de detecção de mudança. 2) Imagem IKONOS 2002. 3) Imagem Google Earth 2017. Fonte: 1) Elaboração própria. 2) IG (2002). 3) Google (2018).

É importante destacar que as alterações captadas pelas análises aqui apresentadas são aquelas capazes de alterar a temperatura média de uma área de $1 \mathrm{~km}^{2}$. Alterações em pequenas áreas também podem apresentar impactos significativos na $T_{\text {sup. As alterações }}$ verificadas são, portanto, dependentes da escala do sensor termal utilizado. 


\section{Temperatura superficial noturna}

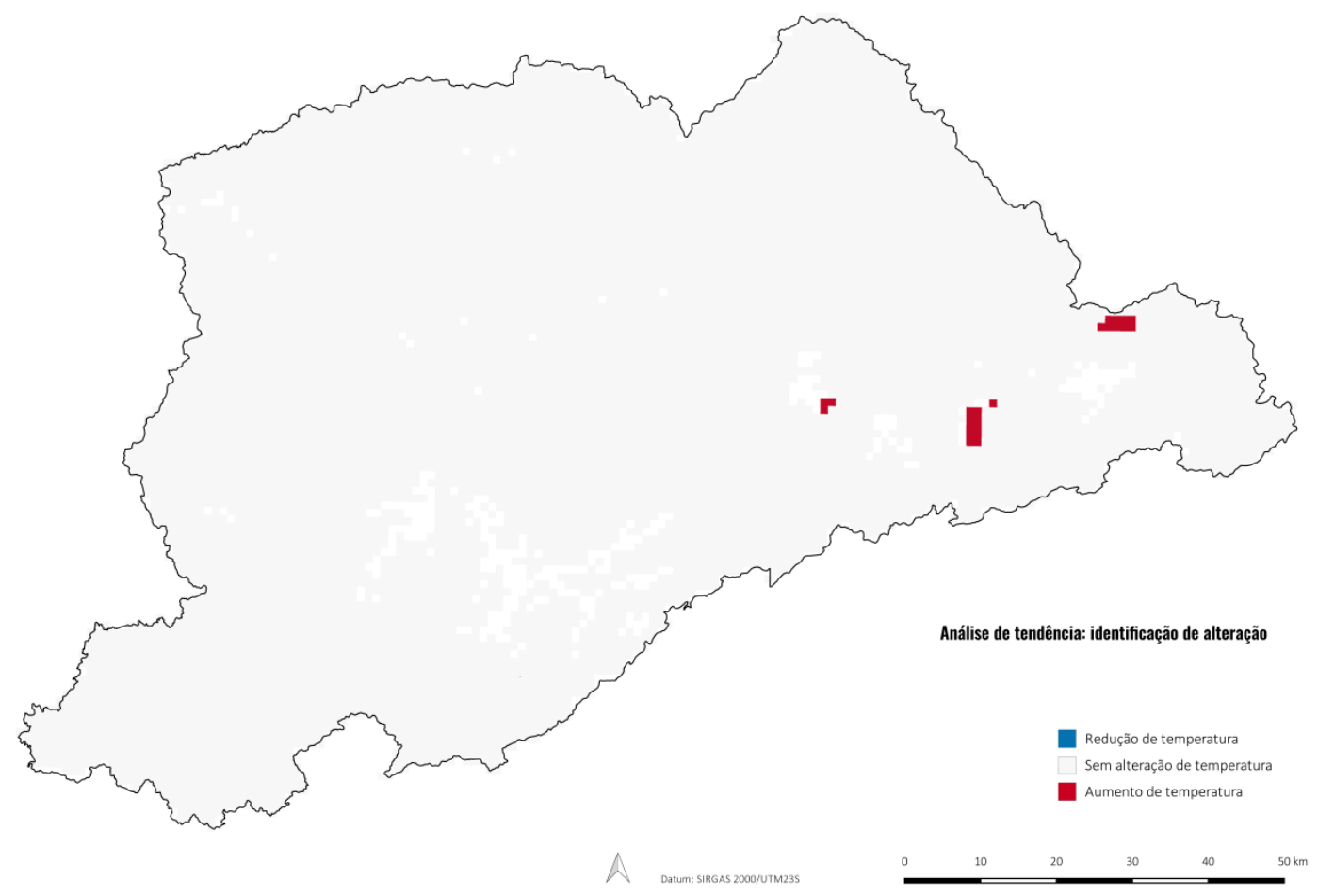

Figura 111. Identificação de tendência. $T_{\text {sup }}$ noturna. Identificação de alteração.

A análise de tendência da $T_{\text {sup }}$ noturna (Figura 111) apresentou apenas alterações positivas em locais muito próximos à corpos d'água existentes ou que foram ampliados no período de análise. Assim, considerou-se que a $T_{\text {sup }}$ noturna não apresentou alterações significativas no período de análise. 


\subsubsection{Caracterização temporal dos índices de vegetação}

As análises de tendência dos índices de vegetação seguiram o mesmo procedimento das análises termais, sendo realizado o ajuste da reta de regressão linear e consideradas a significância estatística (intervalo de confiança de 95\%) e prática (alterações significativas são aquelas superiores a 0,05) tanto para o NDVI quanto para o EVI. Os resultados são apresentados na resolução espacial de $250 \mathrm{~m}$, divididos em três tipos de mapas. O primeiro identifica se houve ou não alteração significativa, o segundo identifica a magnitude da alteração e, o terceiro, o ano de ocorrência da primeira alteração significativa.

Primeiramente são apresentados os resultados para o NDVI (Figura 112 à Figura 115), em seguida os resultados para o EVI (Figura 116 à Figura 119) e, na sequência, a análise conjunta dos dois índices, com foco nas áreas de maior alteração.

Por apresentar resolução espacial maior que as imagens termais, as análises dos índices de vegetação conseguem captar alterações de menor escala. 
NDVI

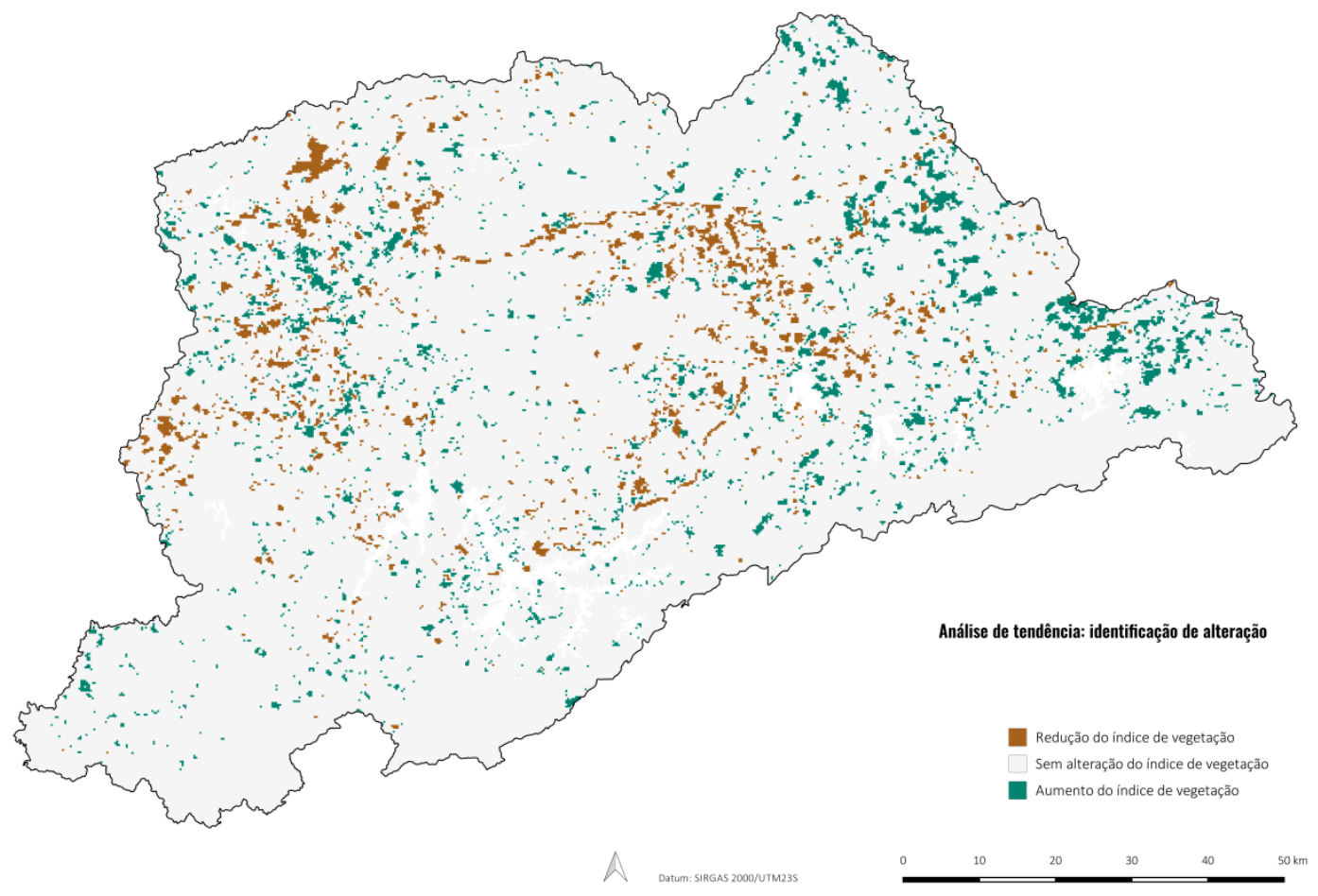

Figura 112. Identificação de tendência. NDVI. Identificação de alteração.

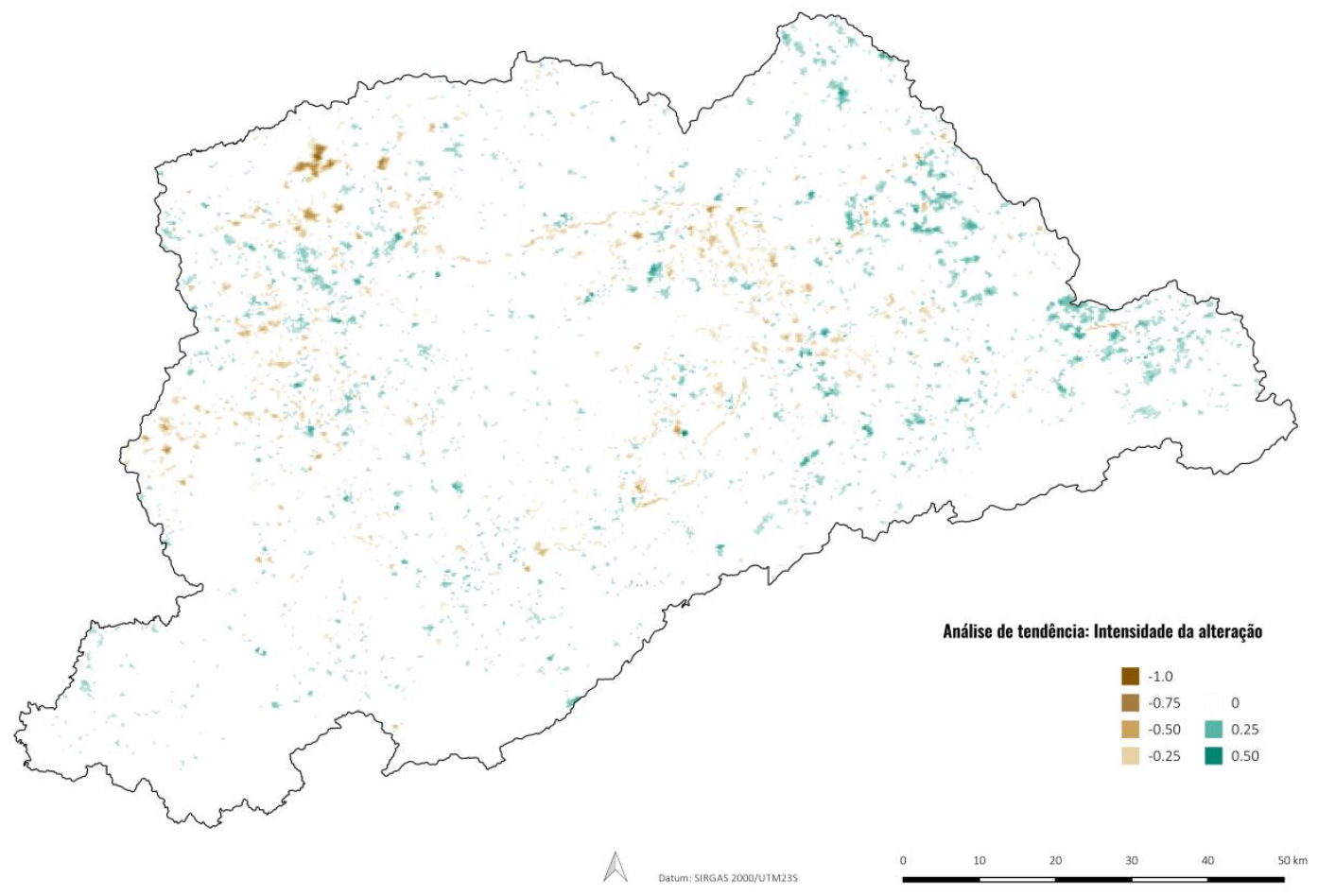

Figura 113. Identificação de tendência. NDVI. Intensidade da alteração. 


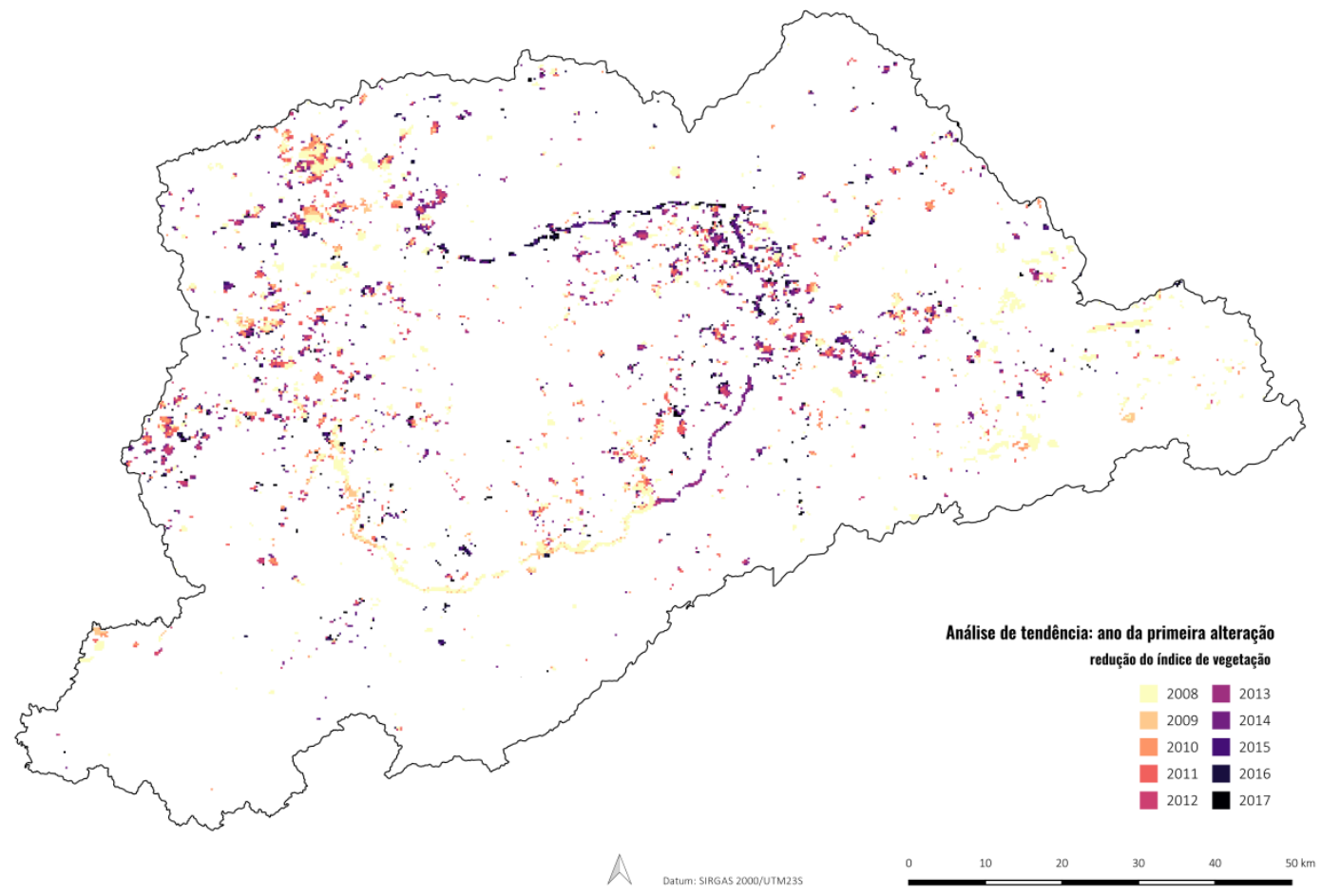

Figura 114. Identificação de tendência. NDVI. Ano de alteração. Redução.

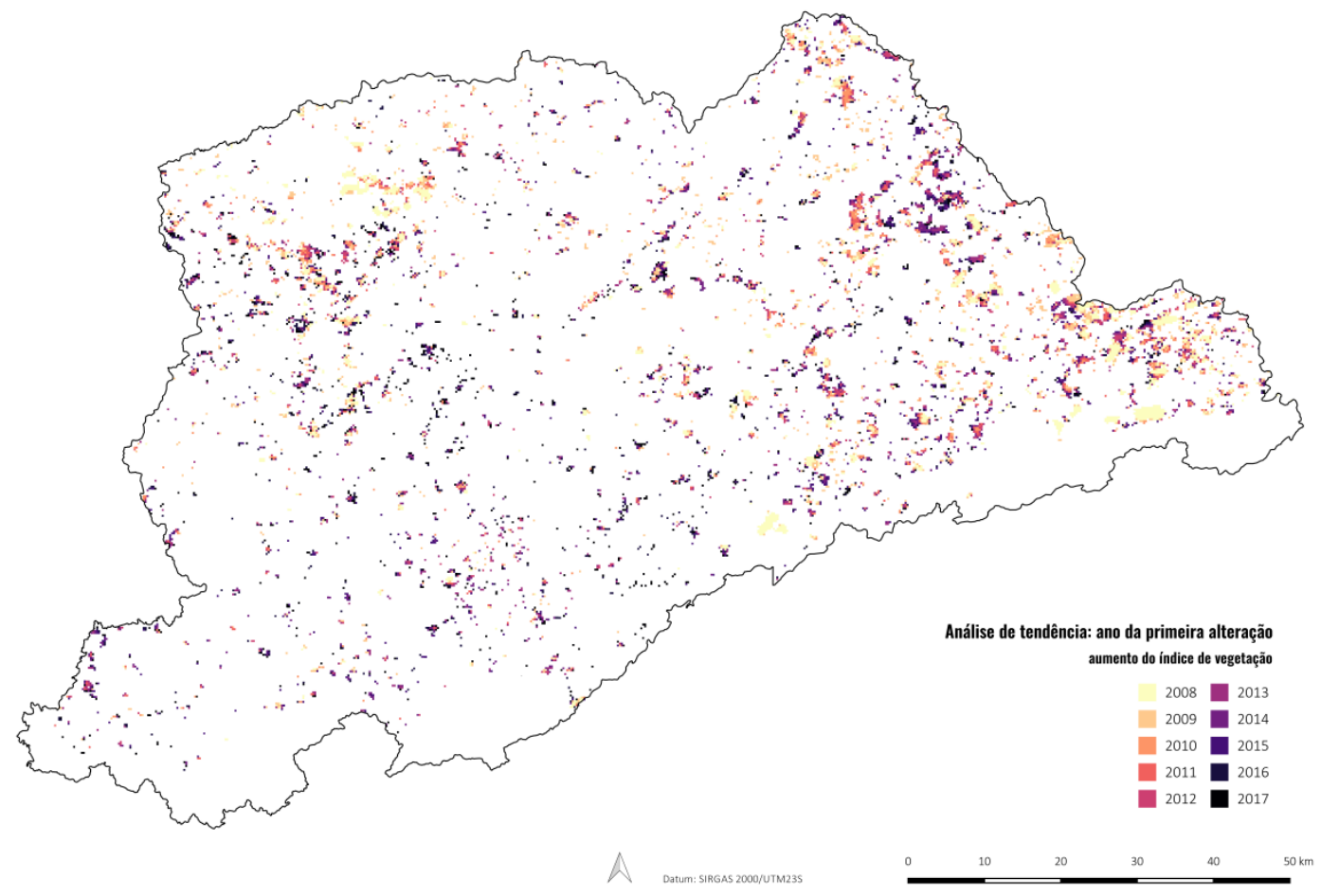

Figura 115. Identificação de tendência. NDVI. Ano de alteração. Aumento. 
EVI

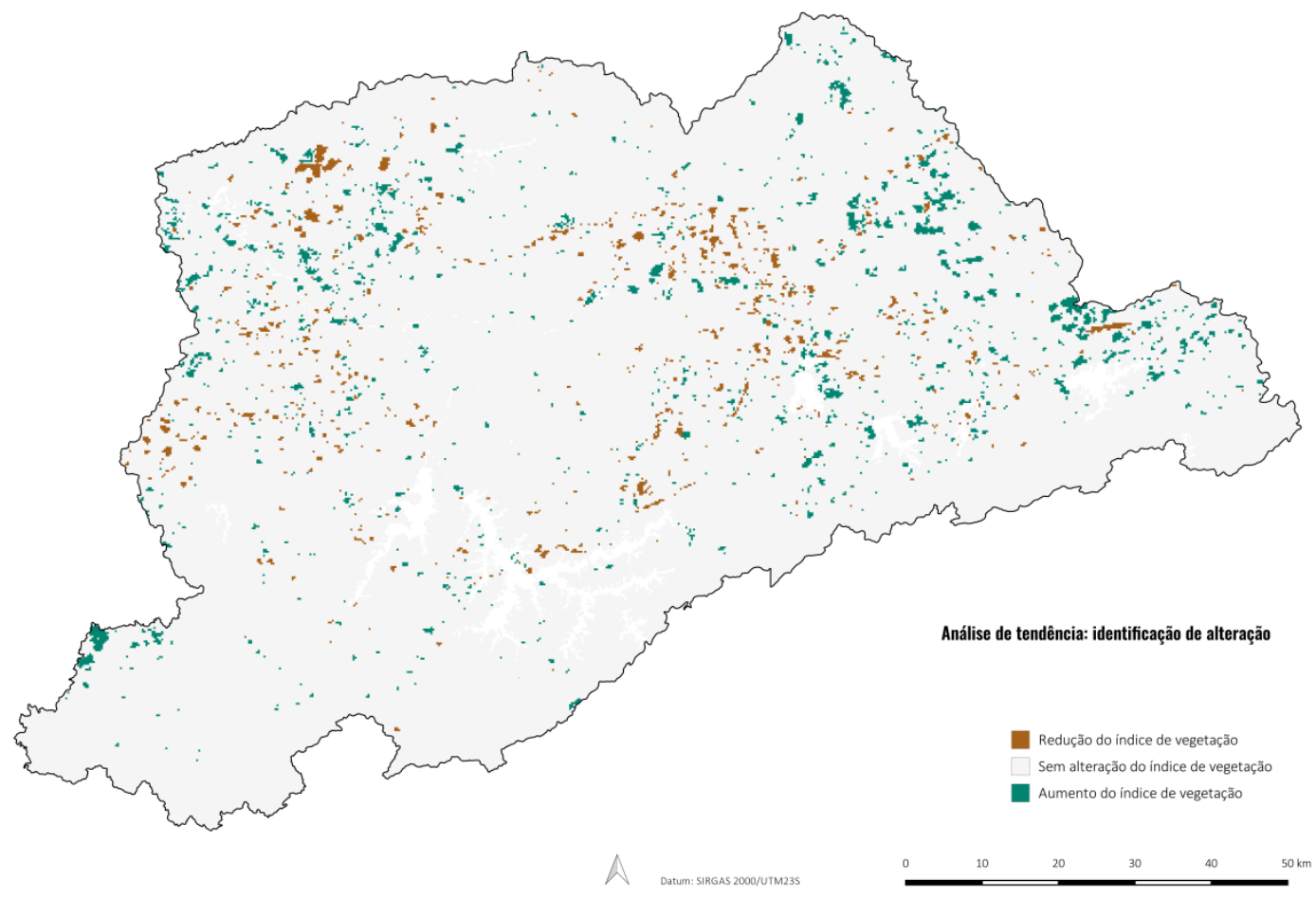

Figura 116. Identificação de tendência. EVI. Identificação de alteração.

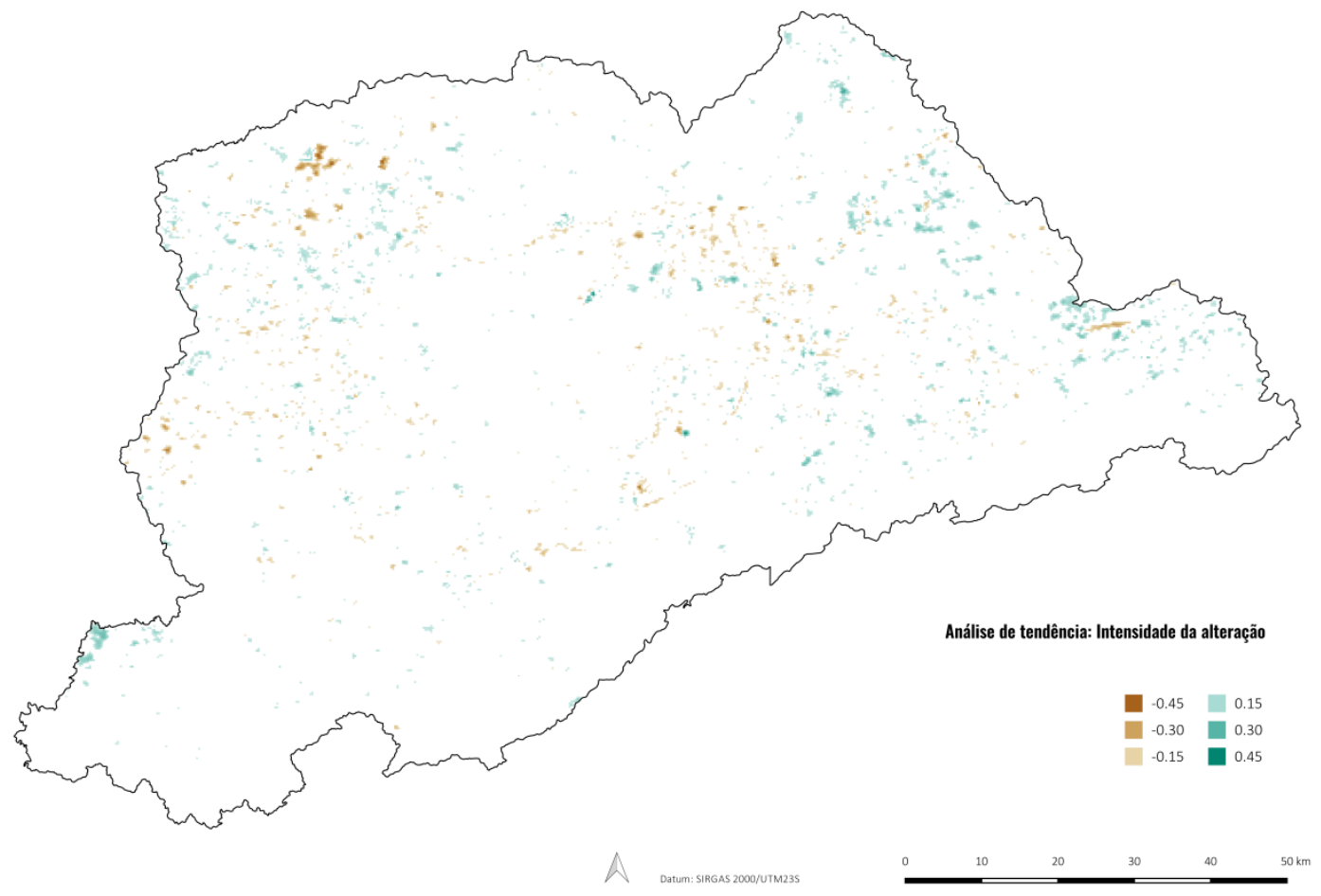

Figura 117. Identificação de tendência. EVI. Intensidade da alteração. 


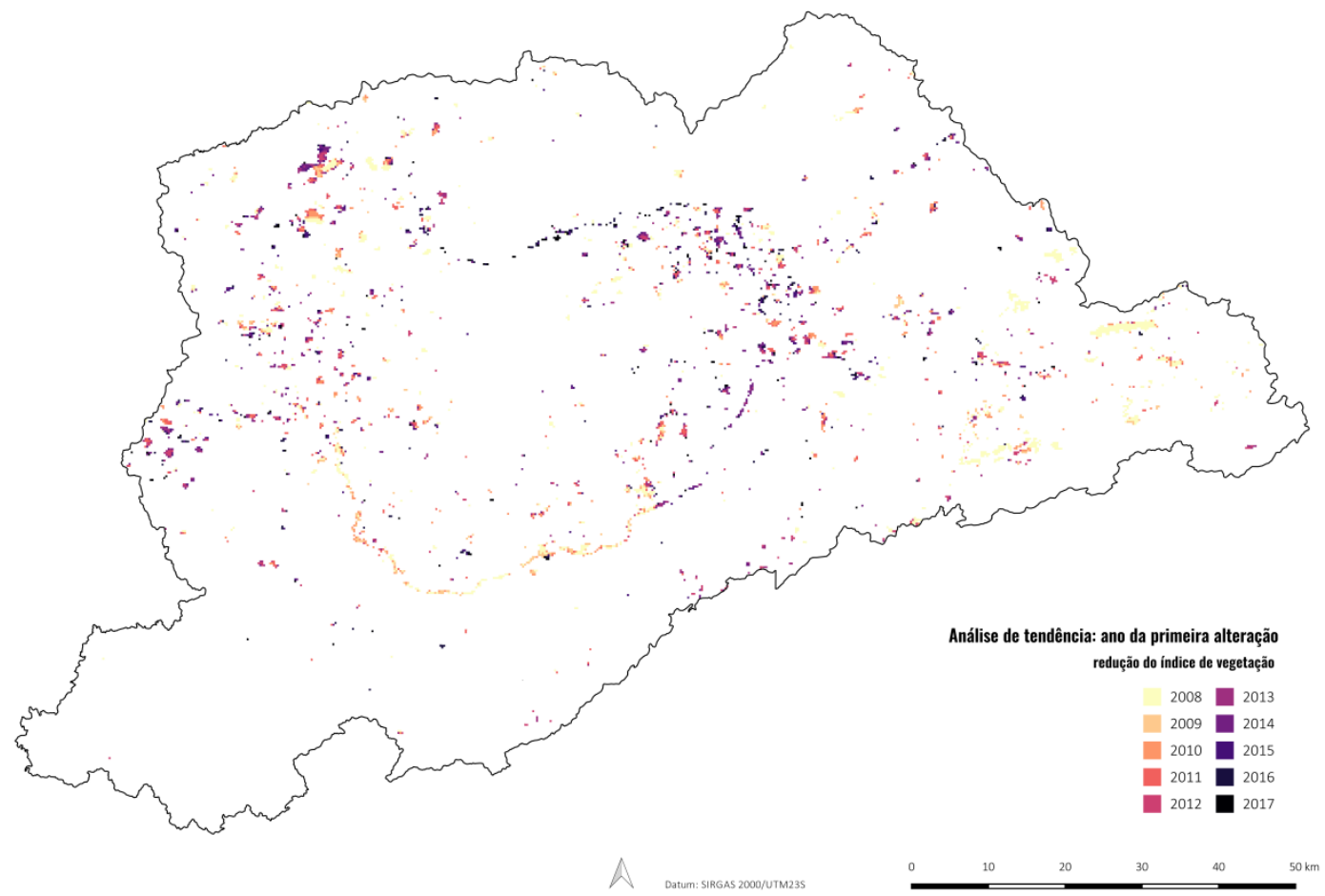

Figura 118. Identificação de tendência. EVI. Ano de alteração. Redução.

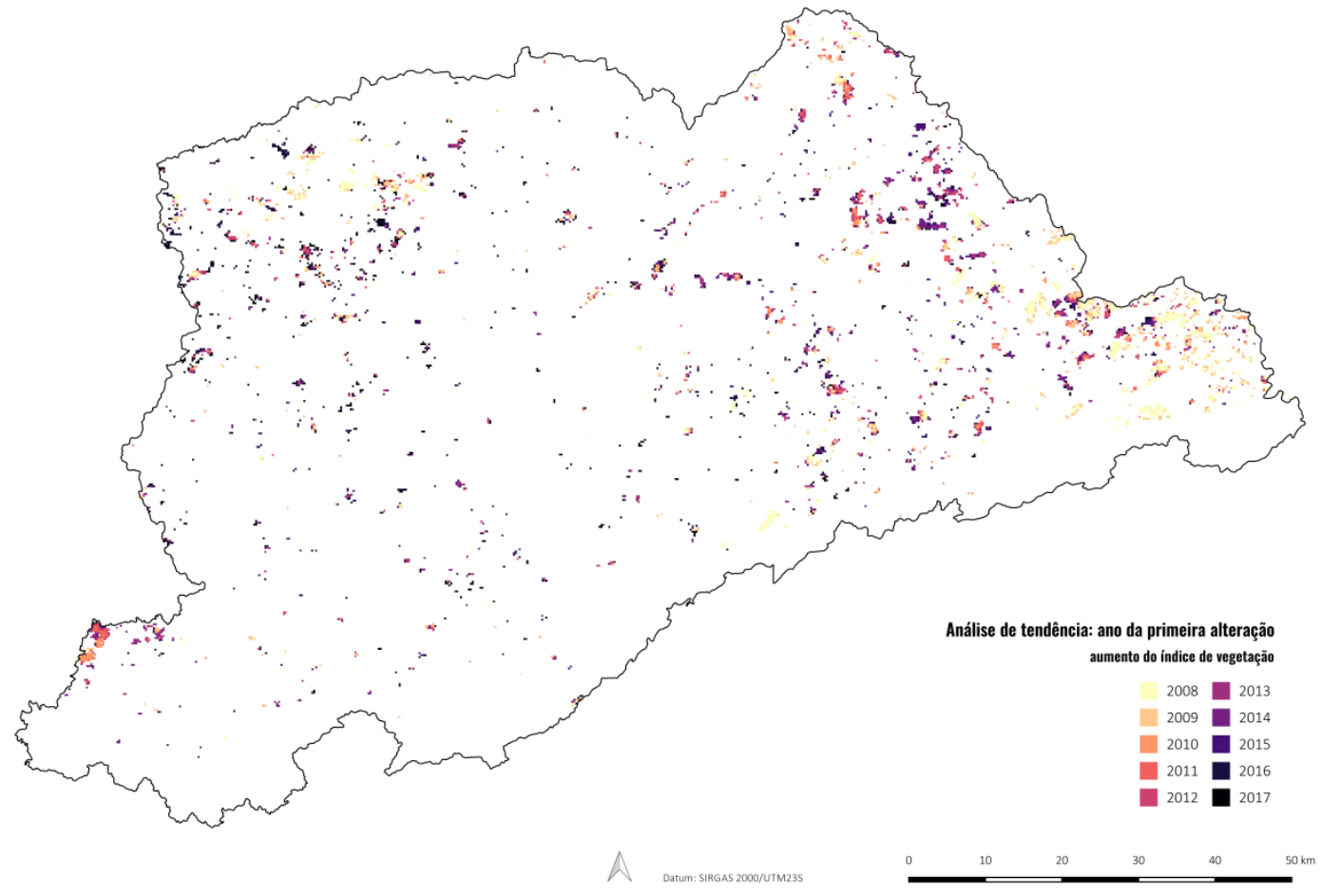

Figura 119. Identificação de tendência. EVI. Ano de alteração. Aumento. 
As análises temporais para os dois índices de vegetação apresentaram resultados espacialmente semelhantes, apesar dos resultados do NDVI captarem tendência significativa em um maior número de pixels.

De maneira geral, reduções e aumentos dos índices de vegetação ocorrem em todas as áreas da RMSP, com exceção da área urbana central. Porém, é possível identificar algumas áreas onde as alterações são mais intensas e concentradas. As áreas de alteração de NDVI (por ocorrerem em maior número) foram verificadas individualmente e foi possível identificar alguns padrões nas alterações que serão descritos de acordo com as áreas identificadas na Figura 120.

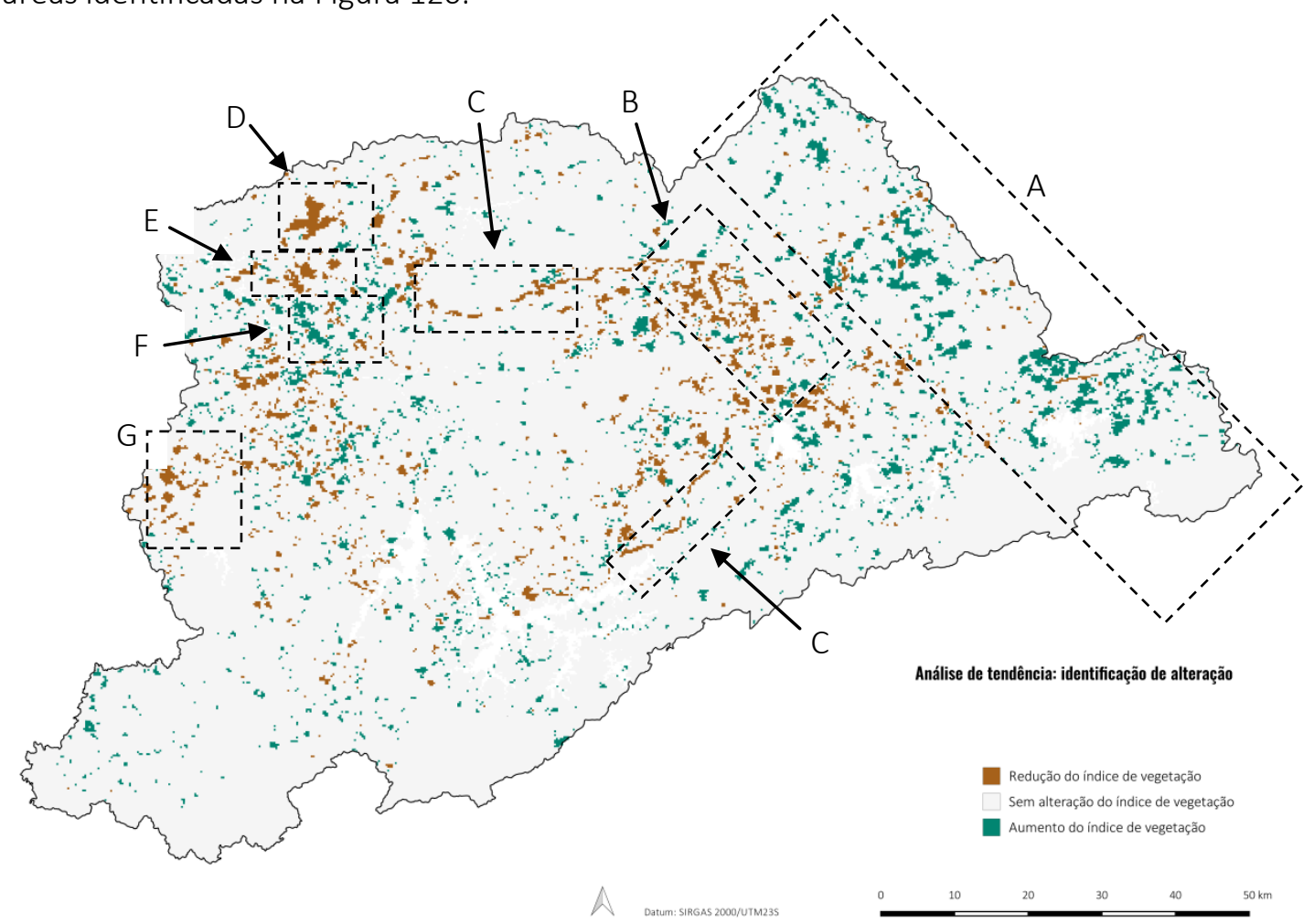

Figura 120. Padrões de alteração dos índices de vegetação.

Região A. Aumento dos índices de vegetação devido à transformação de áreas de pastagem e de agricultura em áreas de cultivo de eucalipto.

Região B. Redução dos índices de vegetação devido à expansão da área urbana (residências de padrão médio a baixo e galpões industriais). 
Região C. Redução dos índices de vegetação devido à implantação do Rodoanel Mário Covas.

Região D. Redução dos índices de vegetação devido à implantação de galpões industriais próximos à Rodovia dos Bandeirantes.

Região E. Redução dos índices de vegetação devido à implantação de loteamentos residenciais em Santana de Parnaíba e Cajamar.

Região F. Aumento dos índices de vegetação devido à conclusão da implantação de loteamentos residenciais de alto padrão na região de Santana de Parnaíba que se encontravam em obras (solo exposto) no início do período de análise.

Região G. Redução dos índices de vegetação devido à implantação de loteamentos residenciais (padrão médio a alto) em Vargem Grande Paulista e Cotia.

Foram verificadas ainda áreas com aumento dos índices de vegetação na área urbana devido à desativação de aterros (Interlagos e parte do aterro Sapopemba), conclusão de obras que no início do período de análise encontravam-se com solo exposto e adensamento da vegetação dos Parques Vila Lobos, do Povo e Ecológico do Tietê.

O ano de ocorrência das primeiras alterações significativas varia, estando relacionado com a implantação das obras ou, no caso das áreas agrícolas, com a data de conversão das culturas ou com sua sazonalidade. Destaca-se, nas imagens com os anos de redução dos índices, tanto do NDVI quanto do EVI (Figura 114 e Figura 118), os períodos de construção do Rodoanel Mário Covas. 


\subsubsection{Tendências de temperatura superficial e índices de vegetação.}

A partir das tendências verificadas para os índices de vegetação e para as temperaturas superficiais, foram produzidos mapas de cruzamento entre as tendências buscando identificar coincidências espaciais. Foram elaborados cruzamentos entre temperaturas superficiais diurnas e noturnas e os dois índices de vegetação. O cruzamento que apresentou maior quantidade de informações foi o cruzamento entre as tendências de $\mathrm{T}_{\text {sup }}$ diurna e o NDVI. Foram elaborados cruzamentos tanto com resolução de $1 \mathrm{~km}$ (Figura 121) quanto na resolução de 250 m (Figura 122).

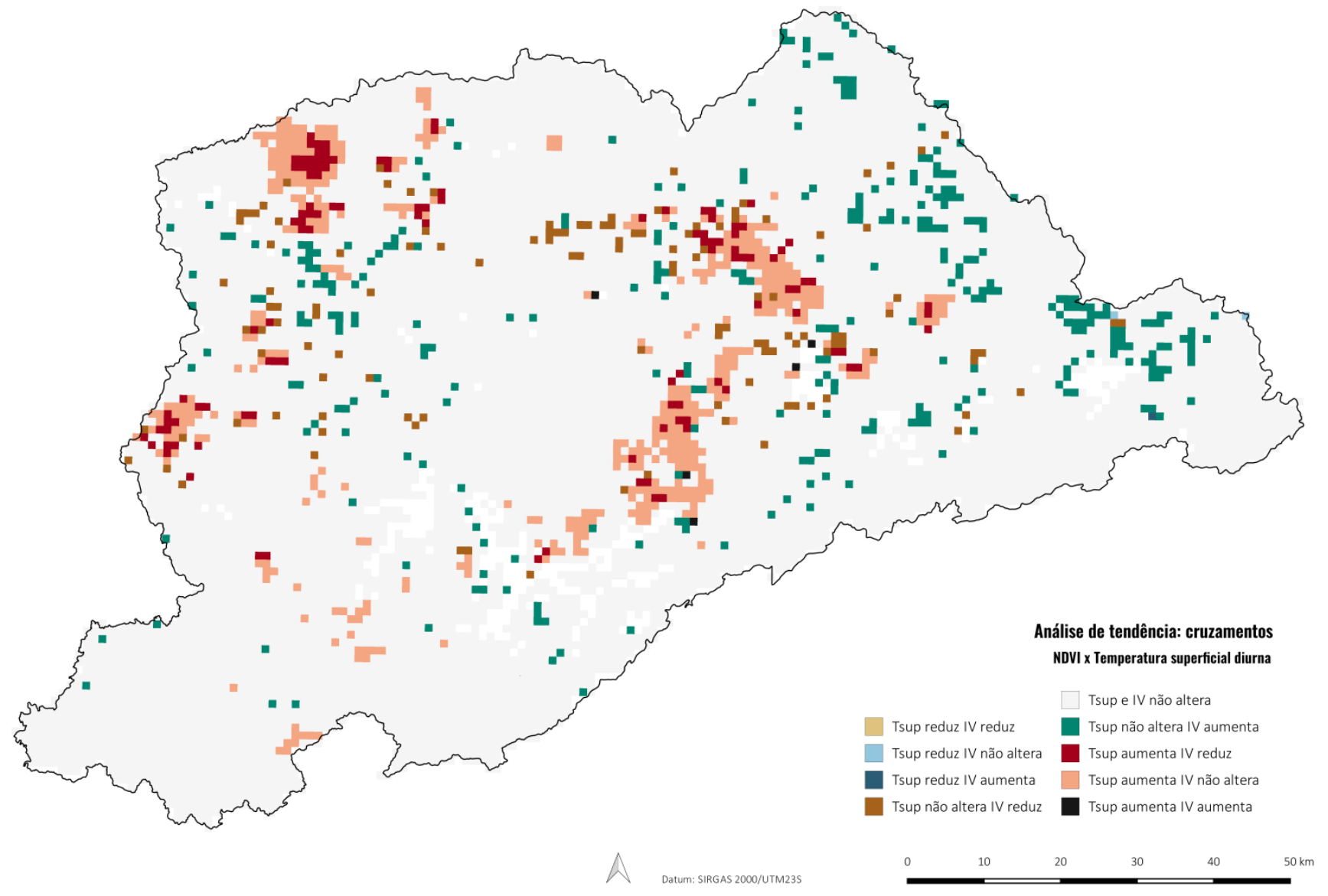

Figura 121. Cruzamento entre tendências: NDVI e $T_{\text {sup }}$ diurna. Resolução: $1 \mathrm{~km}$

$A T_{\text {sup }}$ diurna apresenta tendência de aumento e o NDVI tendência de redução em áreas que sofreram expansão urbana sobre áreas naturais. Áreas já urbanizadas, ou em processo de urbanização em 2003, que sofreram aumento de impermeabilização (com a implantação de pavimentação asfáltica) ou adensamento construtivo, apresentaram 
aumento de $T_{\text {sup }}$ sem alteração dos índices de vegetação; por outro lado, áreas onde se verificou alteração do tipo de cultura agrícola apresentaram tendência de aumento do NDVI sem alteração da $T_{\text {sup. }}$.

Na imagem com $250 m$ de resolução espacial (Figura 122) verifica-se a ampliação das áreas que apresentaram tendência de aumento ou redução da vegetação sem impacto na $T_{\text {sup }}$. Isso indica que as alterações na vegetação ocorreram em escala insuficiente para impactar a $T_{\text {sup }}$ média em $1 \mathrm{~km}^{2}$.

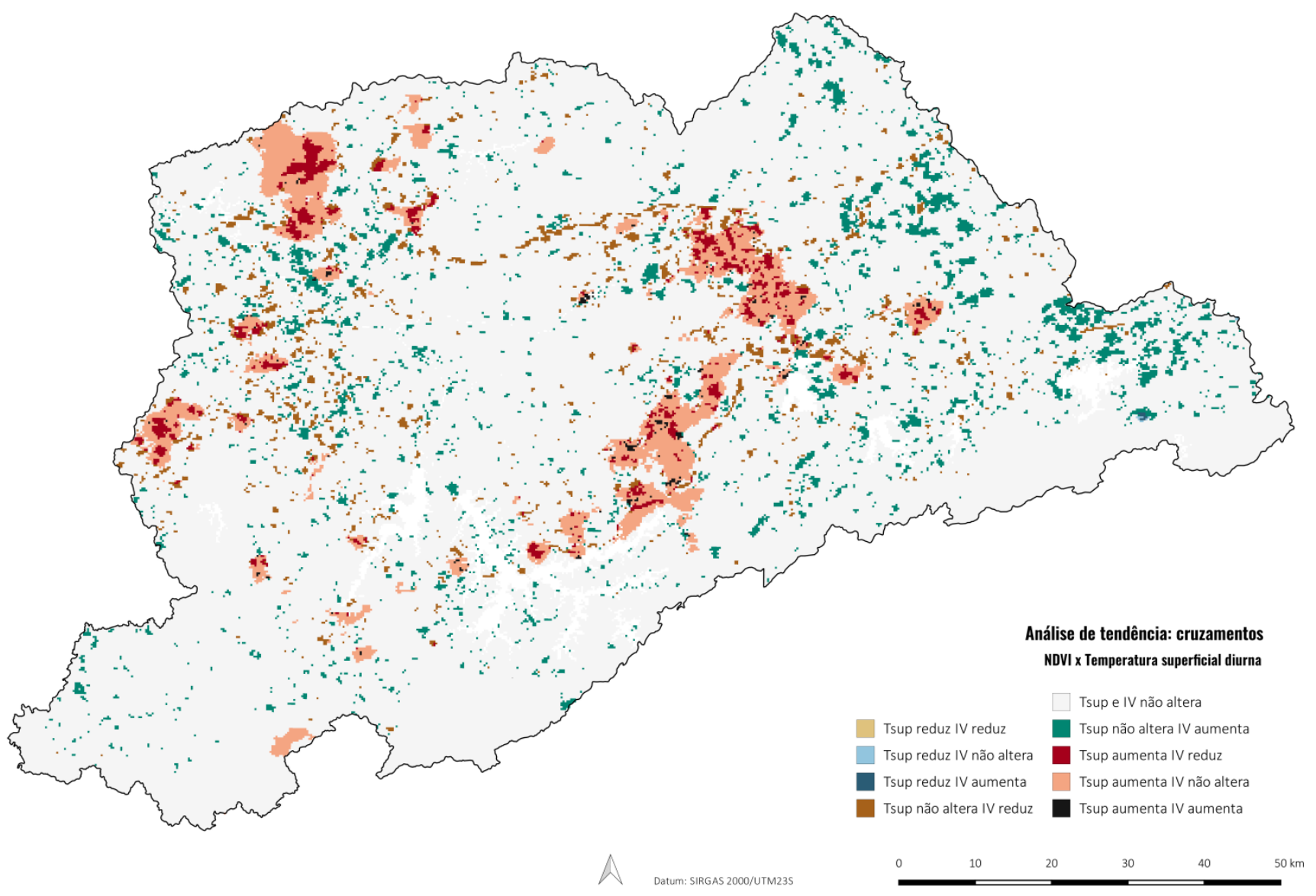

Figura 122. Cruzamento entre tendências: NDVI e $T_{\text {sup }}$ diurna. Resolução: $250 \mathrm{~m}$

O impacto da supressão da vegetação captada na escala do índice de vegetação, porém não captada na escala da $T_{\text {sup, }}$ pode ser exemplificado no trecho norte do Rodoanel Mario Covas. Buscando-se evidenciar que se trata apenas de uma diferença na aquisição dos dados e que, caso a $T_{\text {sup }}$ fosse adquirida na mesma escala do índice de vegetação seria 
possível captar o impacto da supressão de vegetação na $T_{\text {sup, foram elaboradas imagens }}$ de $T_{\text {sup }}$ a partir do canal termal do satélite Landsat para os anos de 2002 e 2019. A supressão de vegetação pode ser vista no mapa de deteç̧ão de mudança elaborado a partir dos mapas LCZ de 2002 e 2017 (Figura 123.1) e por meio da comparação entre imagens de alta resolução de 2002 (Figura 123 2) e 2019 (Figura 123 3). A imagem termal de 2002 (Figura 124) foi elaborada a partir de informações do satélite Landsat 7 ETM+, que adquire dados termais com resolução espacial de $60 \mathrm{~m}$ e os fornece com resolução de 30m. A imagem de 2019 (Figura 125) utilizou dados da banda termal do Landsat 8-OLITIRS, que capta e fornece as informações termais com resolução espacial de $100 \mathrm{~m}$. A elaboração das imagens termais a partir dos dados Landsat seguiu o método proposto por (BARSI; BARKER; SCHOTT, 2003).
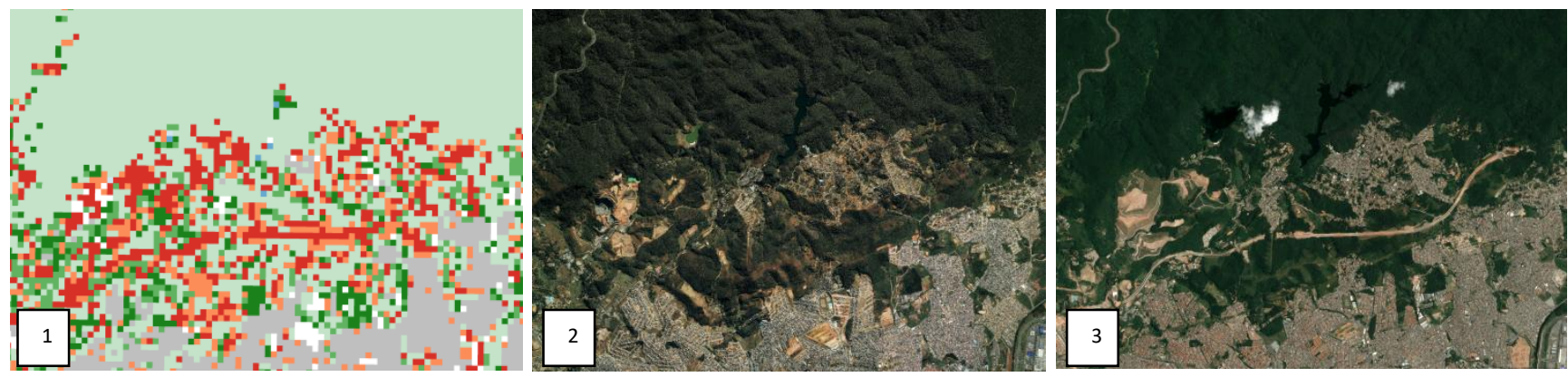

Figura 123. Alterações de vegetação entre 2002 e 2017. Trecho Norte do Rodoanel Mario Covas em Guarulhos. 1) Mapa de deteç̧ão de mudanças. 2) Imagem IKONOS 2002. 3) Imagem Google Earth 2017. Fontes: 1) Elaboração própria. 2) IG (2002). 3) Google (2018).

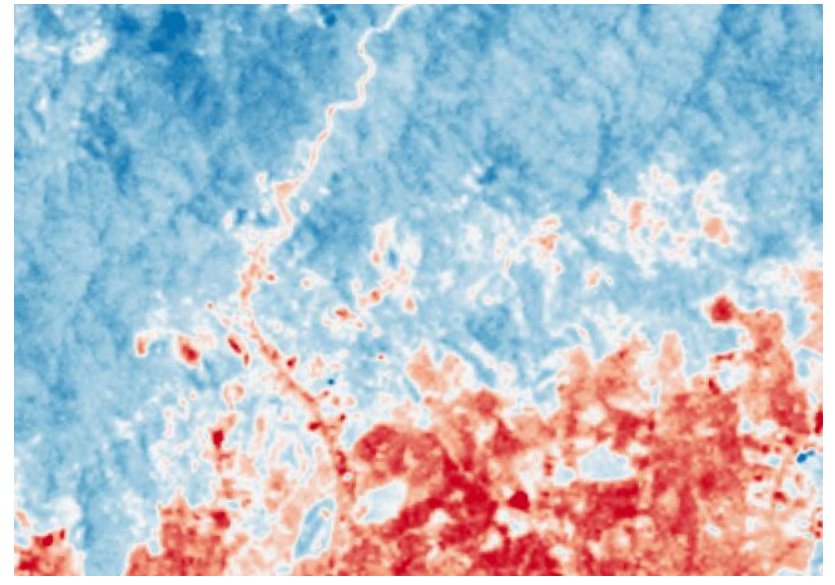

$21^{\circ} \mathrm{C}$

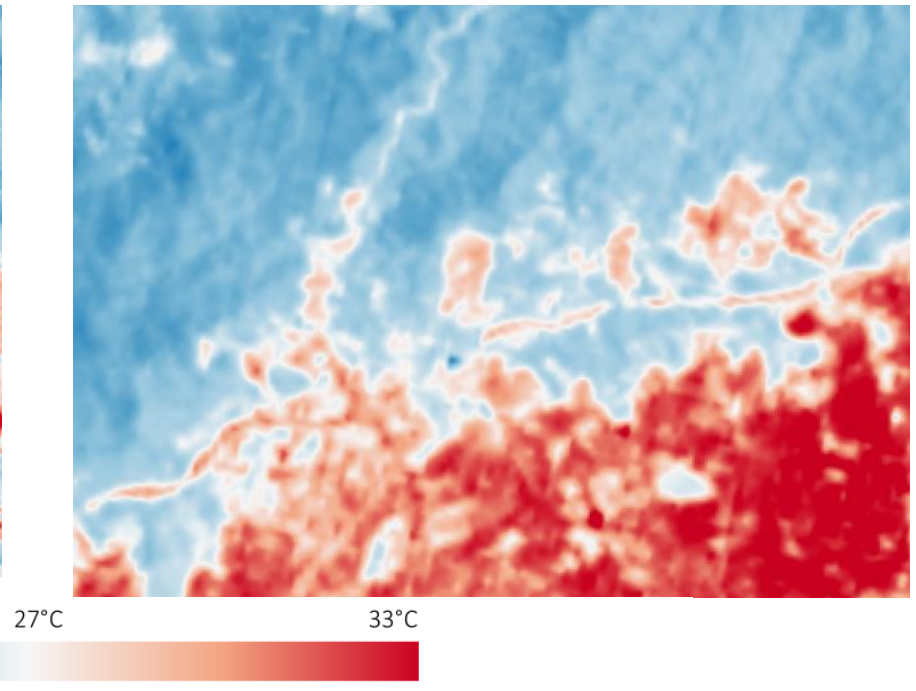

Figura 125. $T_{\text {sup }}$ a partir de dados termais do satélite Landsat 8OLI-TIRS (2019). Resolução espacial 100m.

ETM+ (2002). Resolução espacial 60m. 


\subsubsection{Análises exploratórias.}

A partir dos dados apresentados nos itens anteriores, foram desenvolvidos três estudos de caráter exploratório, sem o tratamento estatístico das análises anteriores. O primeiro teve como objetivo examinar a influência da topografia nos dados de $T_{\text {sup. }}$ O segundo estudo buscou verificar os índices de vegetação de diferentes pontos da RMSP com comportamento da vegetação conhecido e o terceiro examinou a relação ente a $T_{\text {sup, }}$ a vegetação e a renda.

\subsubsection{Análises exploratórias: temperatura superficial e topografia}

Os dados altimétricos para a RMSP foram extraídos de imagens SRTM (Shuttle Radar Topography Mission). Originalmente os dados possuem 30m de resolução espacial, porém para comparação com as imagens termais foram reamostrados para $250 \mathrm{~m}$ por meio de interpolação bilinear (Figura 126). Para verificar se os dados indicavam algum tipo de correlação, foram elaborados gráficos de dispersão entre os dados extraídos da imagem SRTM e os dados extraídos de imagens médias calculadas com todas as cenas das estações secas ou chuvosas. Os gráficos apresentados da Figura 127 à Figura 130 indicam não haver correlação entre as informações para toda a RMSP. Destaca-se, porém, que a área mais urbanizada da RMSP encontra-se entre $700 \mathrm{~m}$ e $900 \mathrm{~m}$ e os gráficos não evidenciam correlação para esta faixa de elevação, indicando que a densidade construtiva das áreas urbanas poderia mascarar efeitos do relevo, porém, para elevações abaixo de $700 \mathrm{~m}$ e acima de $900 \mathrm{~m}$ parece haver uma melhor correlação. Assim, estudos mais detalhados, por faixas de elevação, podem ser necessários para confirmar esta indicação, uma vez que as áreas de menor e maior elevação nos extremos sul e norte da RMSP coincidem com áreas densamente vegetadas. 


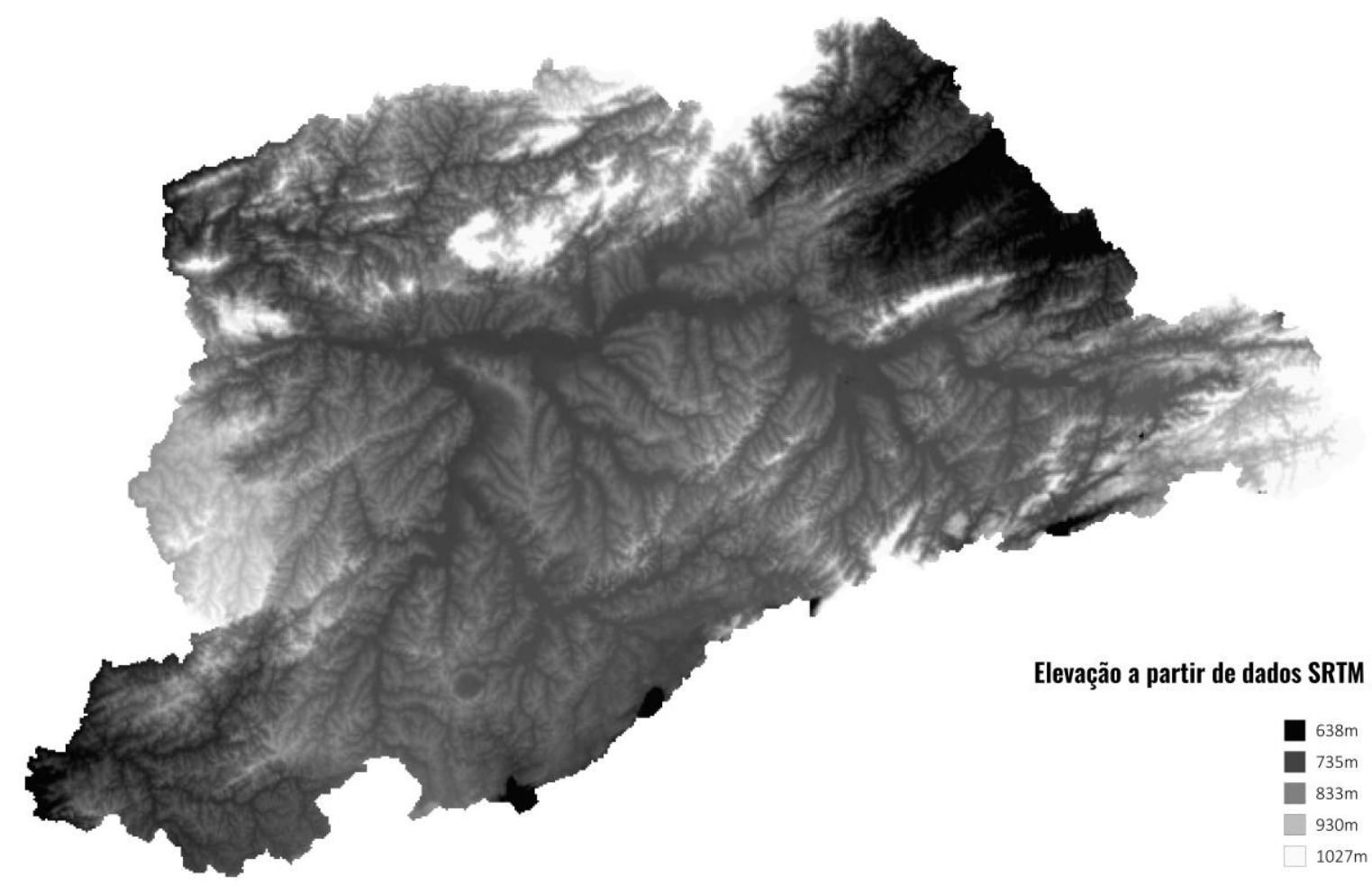

Datum: SIRGAS 2000/UTM23S

Figura 126. Elevação da RMSP. Fonte: elaboração própria a partir de dados SRTM.

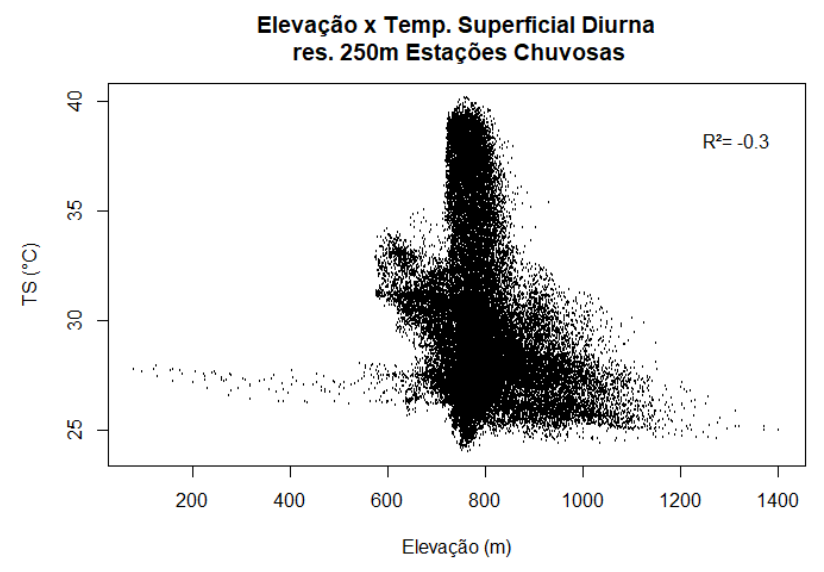

Figura 127. Correlação entre elevação e $T_{\text {sup }}$ diurna das estações chuvosas. Resolução: $250 \mathrm{~m}$.

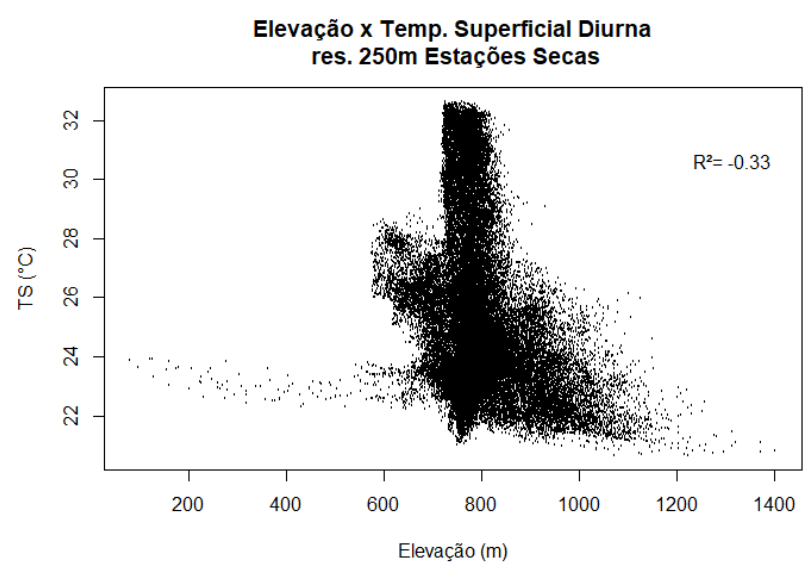

Figura 128. Correlação entre elevação e $T_{\text {sup }}$ diurna das estações secas. Resolução: $250 \mathrm{~m}$. 


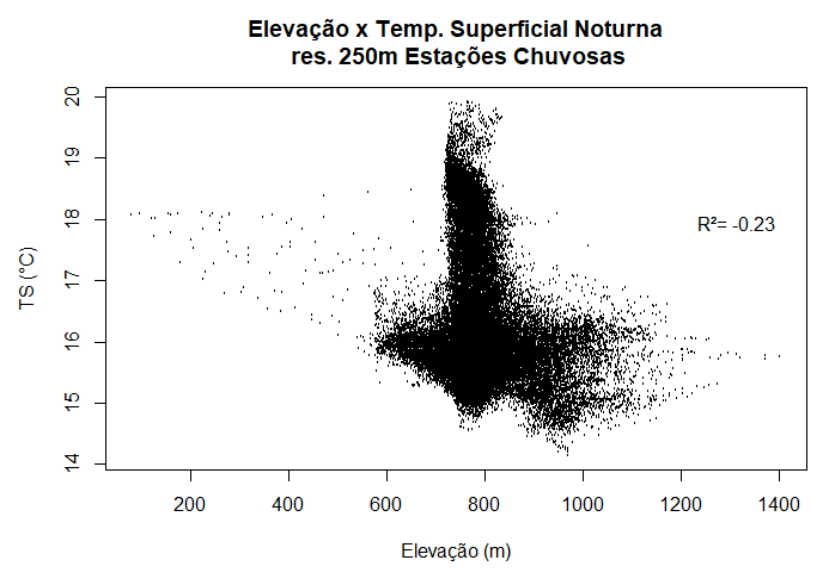

Figura 129. Correlação entre elevação e $T_{\text {sup }}$ noturna das estações chuvosas. Resolução: $250 \mathrm{~m}$.

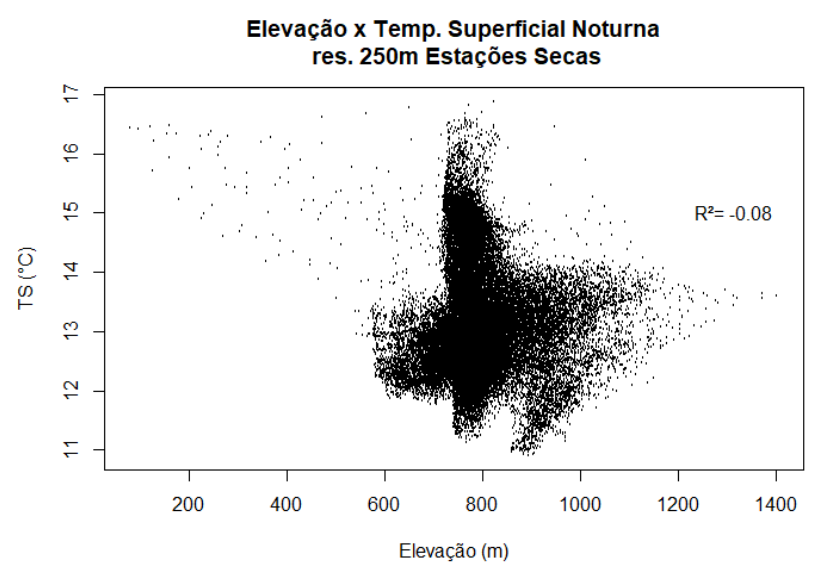

Figura 130. Correlação entre elevação e $T_{\text {sup }}$ noturna das estações seca. Resolução: 250m.

\subsubsection{Análises exploratórias: Índices de vegetação}

A variabilidade dos índices de vegetação ao longo do tempo foi objeto de um estudo de caráter exploratório, sem o tratamento estatístico das análises anteriores, cujo objetivo foi examinar diferentes pontos da RMSP com comportamento da vegetação conhecido.

Foram escolhidas áreas com vegetação densa em locais protegidos: Parque da Cantareira, Parque Fontes do Ipiranga e Reserva Morro Grande. Área com vegetação menos adensada: Parque do Ibirapuera. Áreas com vegetação herbácea ou arbustiva: duas áreas de pastagem em Santa Isabel, e áreas com maior variabilidade da quantidade de vegetação: Área de cultivo de eucalipto em Guararema e área que sofreu processo de urbanização em Cajamar (Figura 131). 


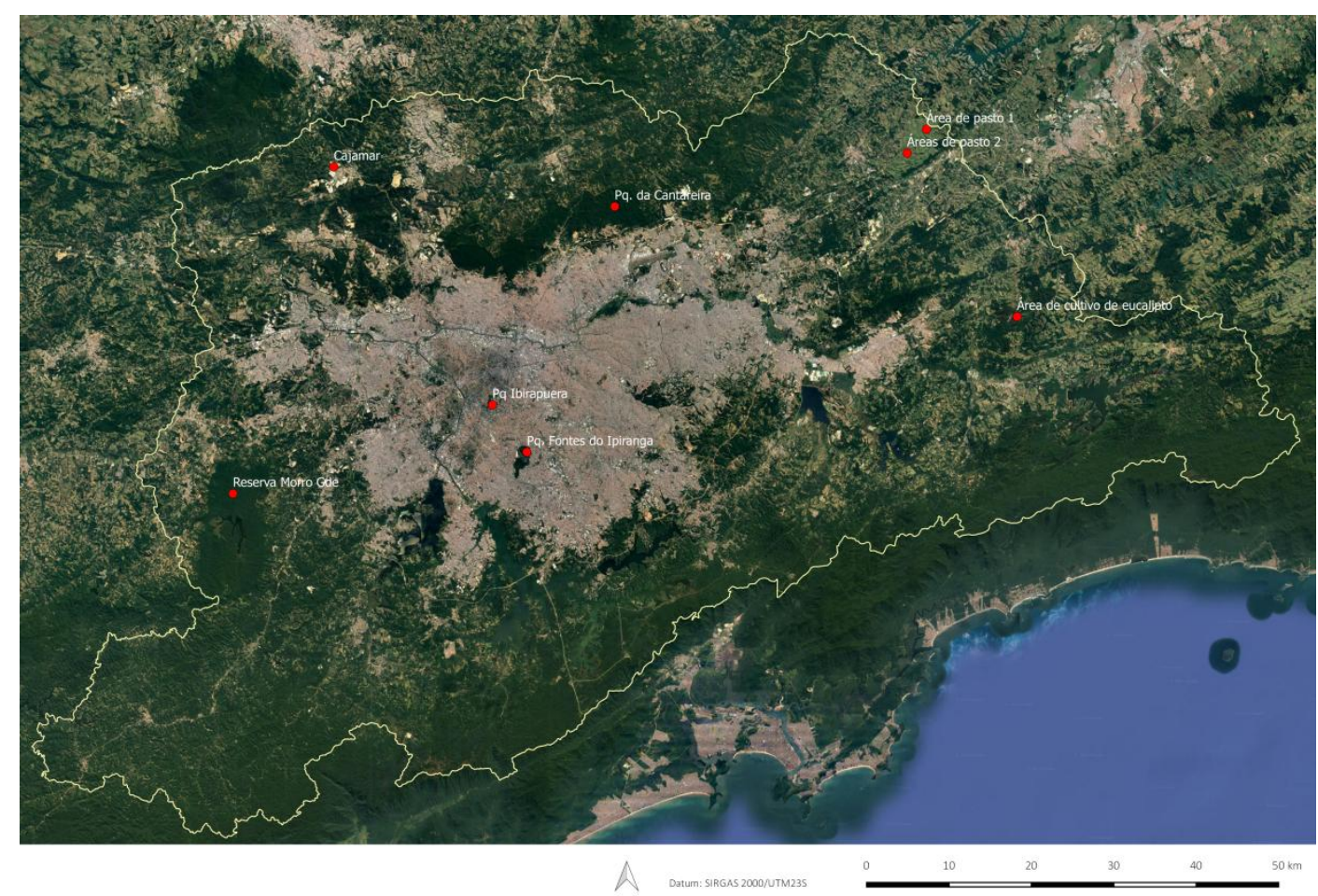

Figura 131. Pontos de interesse para estudo de sazonalidade dos índices de vegetação. Fonte:Google (2018).

Para cada ponto de interesse (Figura 132) foram extraídos os valores dos índices de vegetação de todas as estações analisadas.

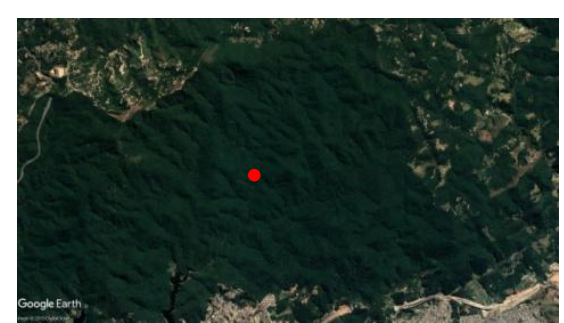

Parque da Cantareira (2017)

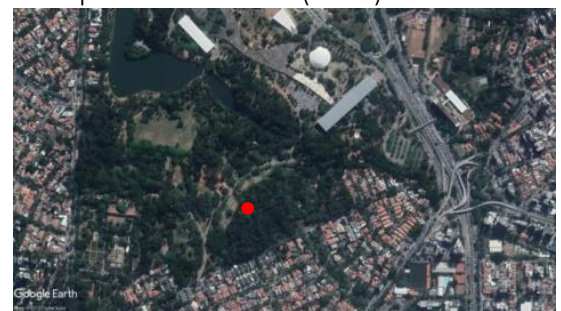

Parque do Ibirapuera (2017)

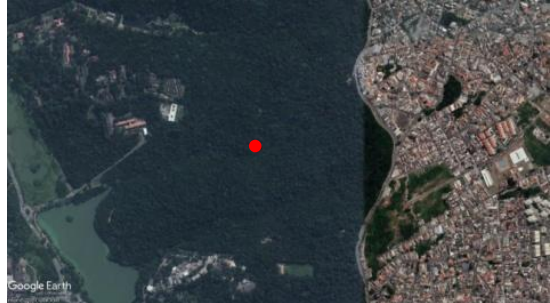

Parque Fontes do Ipiranga (2017)

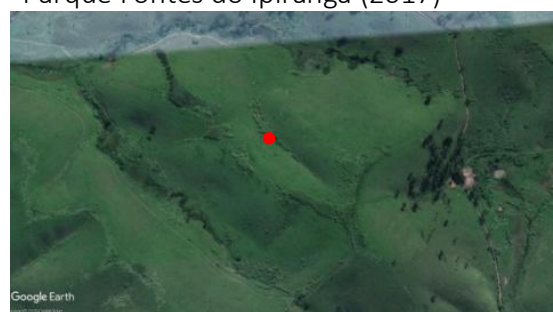

Pastagem 1 (2017)

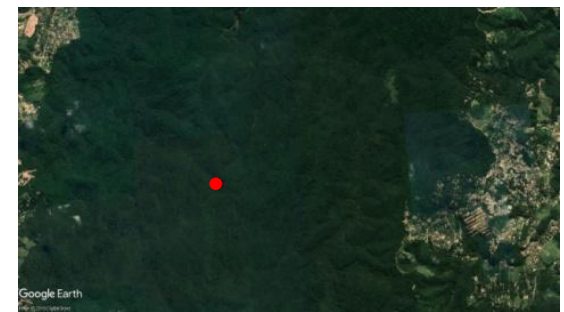

Reserva Morro Grande (2017)

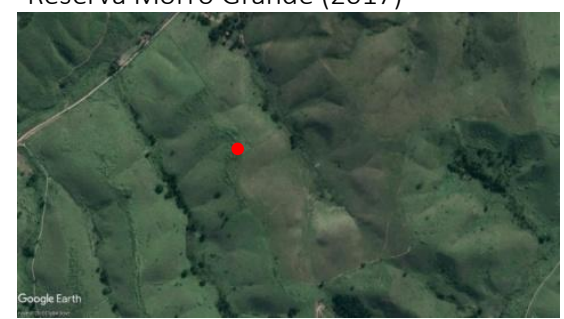

Pastagem 2 (2017) 


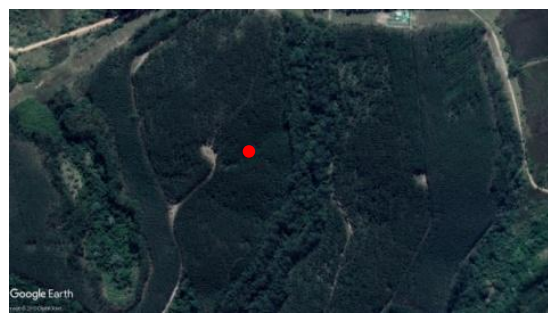

Área de cultivo de eucalipto (2017)

Area de cultivo de eucalipto (2017) Área em Cajamar (2002)
Figura 132. Tipo de ocupação dos pontos de interess. Fonte:Google (2018

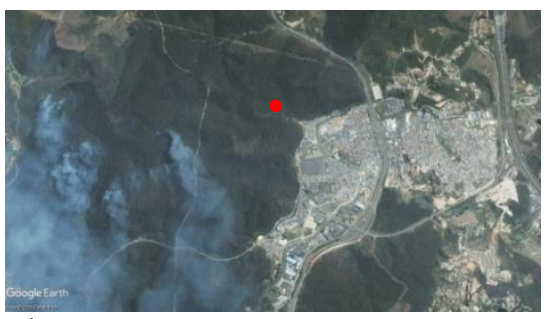

Área em Cajamar (2002)

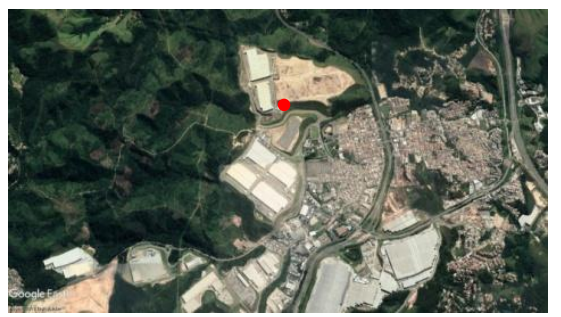

Área em Cajamar (2017)

Os gráficos da Figura 133 e da Figura 136 apresentam a variação do NDVI e do EVI ao longo do período. A precipitação média ${ }^{45}$ de cada estação também é apresentada para que sua influência nos índices de vegetação seja verificada. Os pontos de interesse foram agrupados em dois gráficos para melhor visualização.

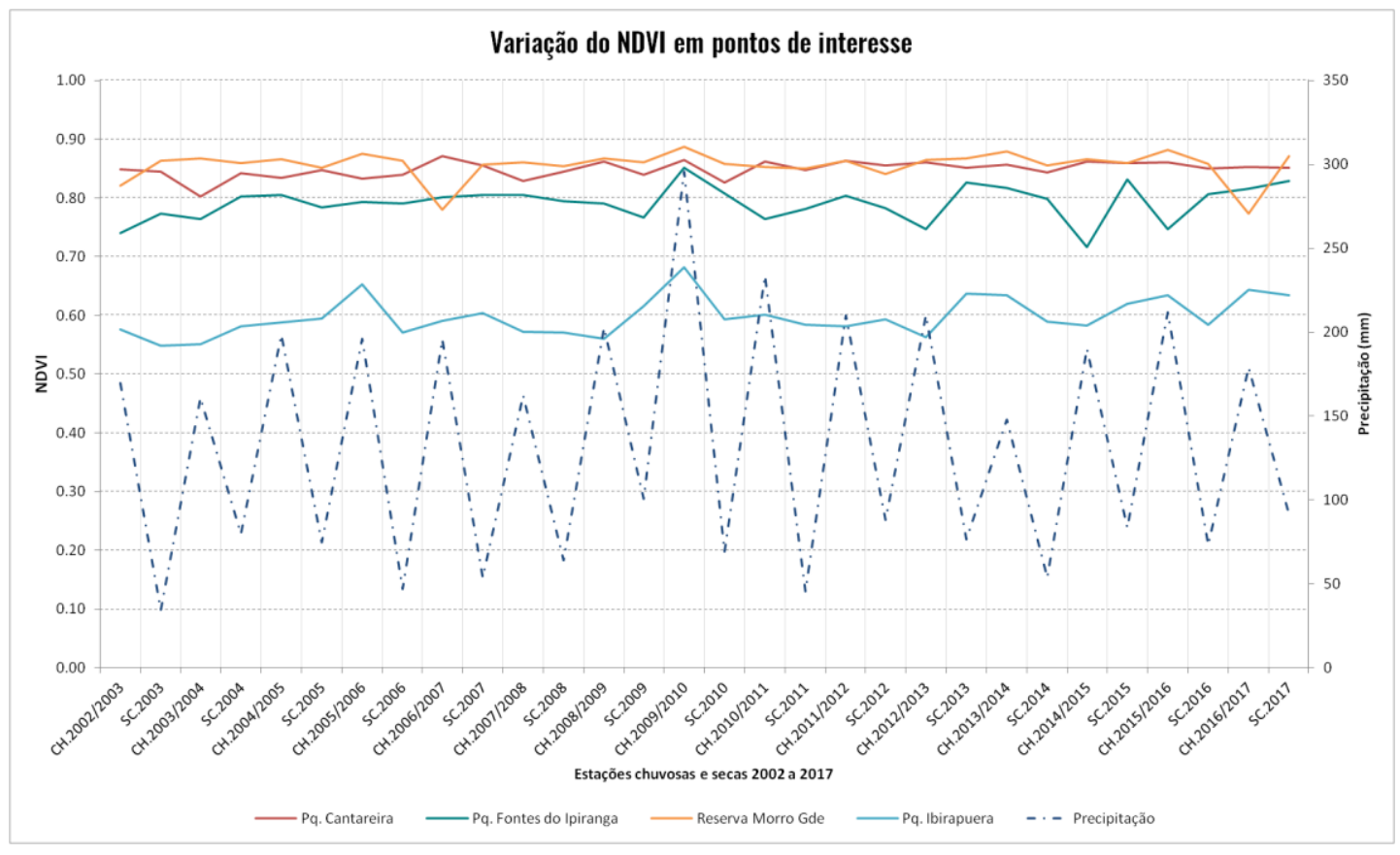

Figura 133. Variação do NDVI. Parque da Cantareira, Parque Fontes do Ipiranga, Reserva Morro Grande e Parque do Ibirapuera.

${ }^{45}$ Média calculada a partir de dados mensais da estação meteorológica do IAG Água Funda. 


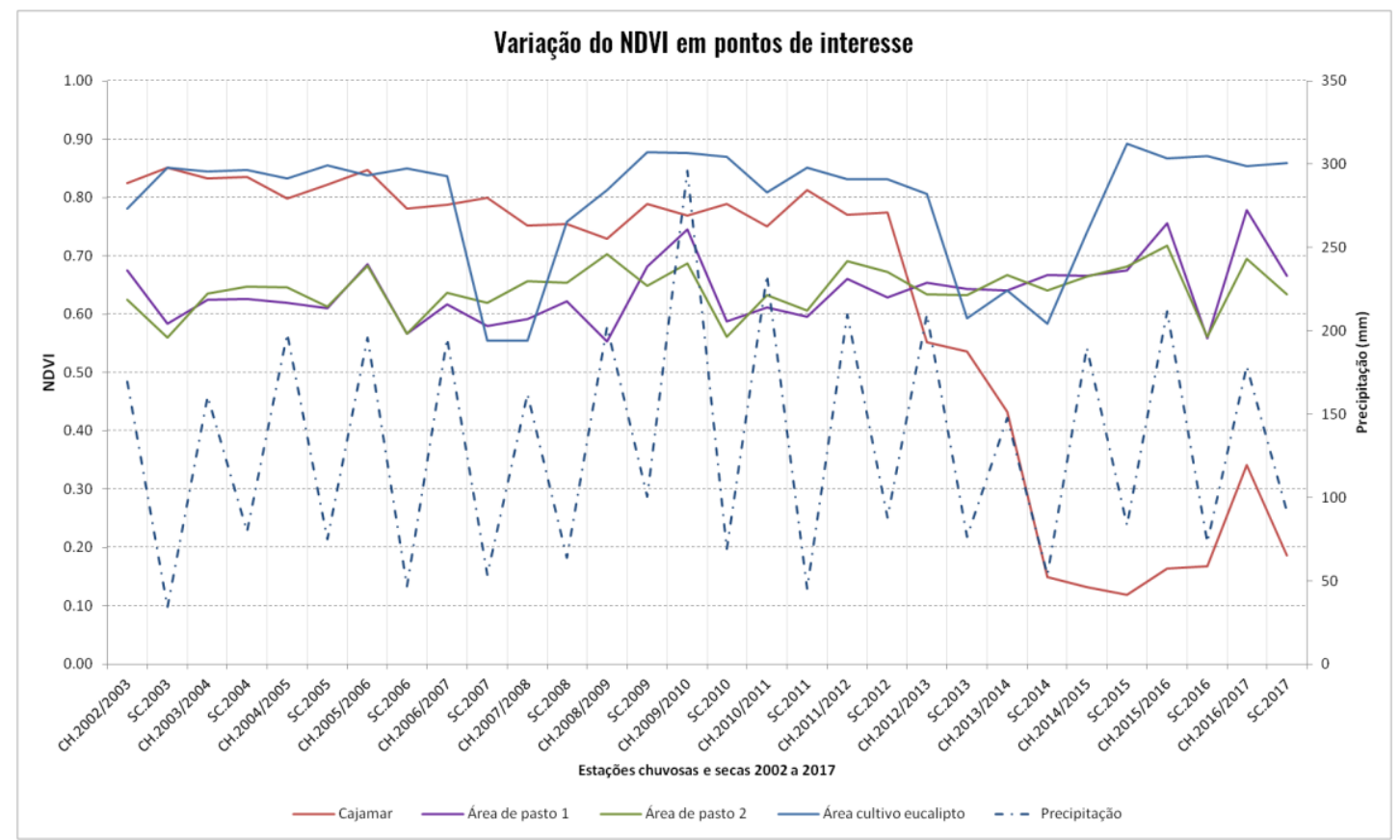

Figura 134. Variação do NDVI. Área que sofreu processo de urbanização em Cajamar, áreas de pasto em Santa Isabel e área de cultivo de eucalipto em Guararema.

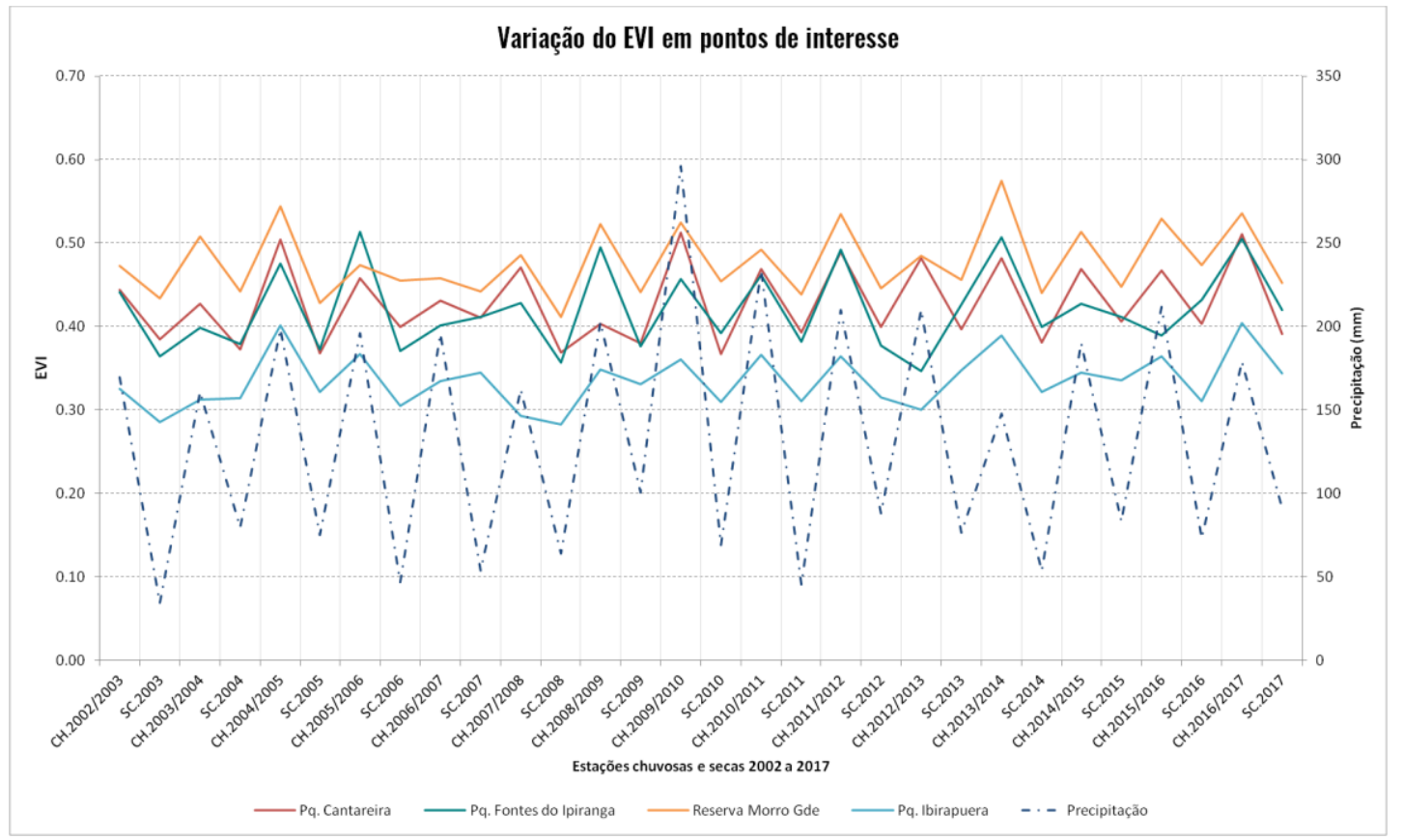

Figura 135. Variação do EVI. Parque da Cantareira, Parque Fontes do Ipiranga, Reserva Morro Grande e Parque do Ibirapuera. 


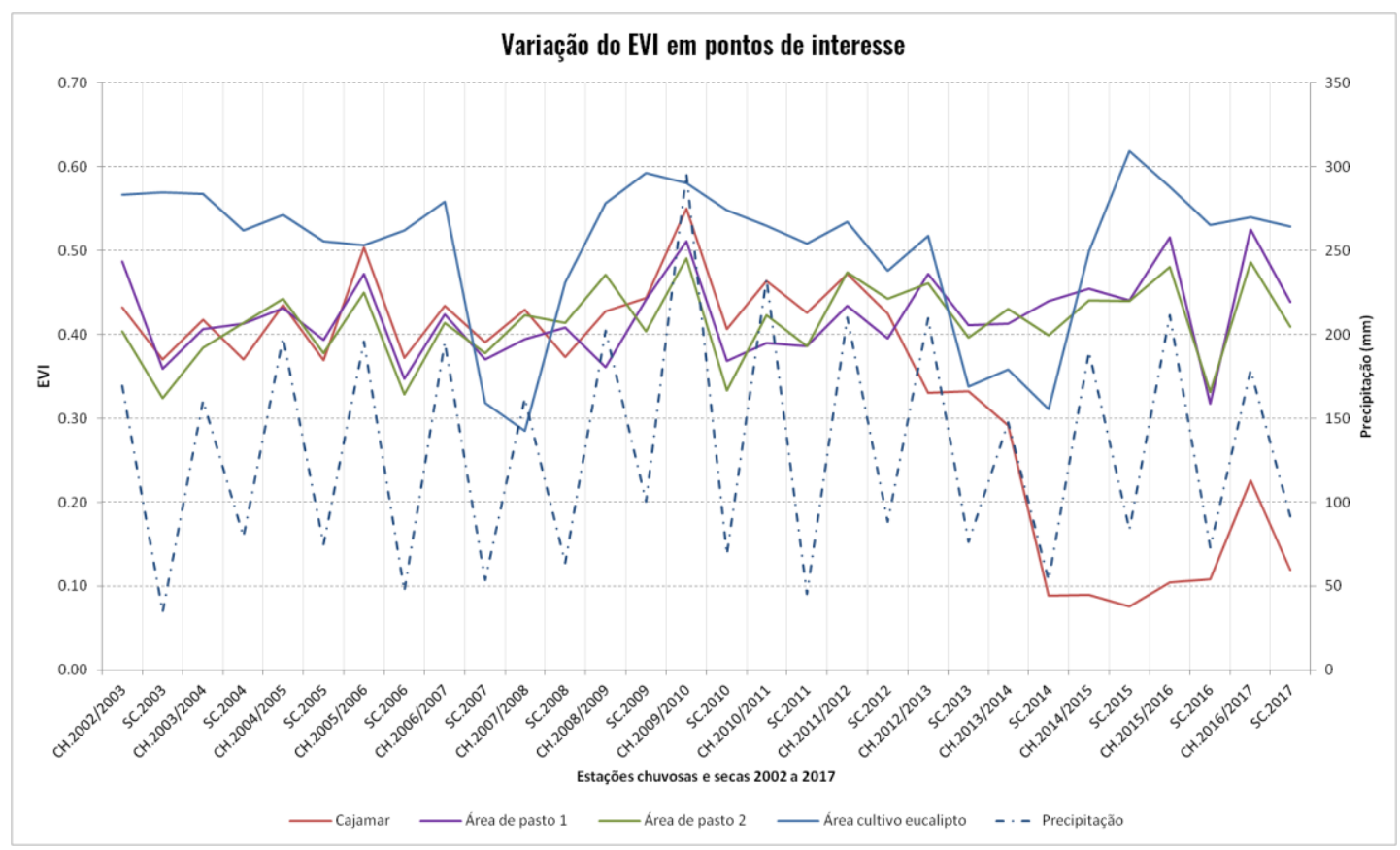

Figura 136. Variação do EVI. Área que sofreu processo de urbanização em Cajamar, áreas de pasto em Santa Isabel e área de cultivo de eucalipto em Guararema.

Em todos os pontos analisados o NDVI apresenta valores superiores e mais estáveis do que o EVI, sugerindo maior sensibilidade do EVI às pequenas variações entre as estações chuvosas e secas.

Apesar da coincidência do pico de NDVI e pluviosidade na estação chuvosa de 2009/2010, as demais estações não apresentam correspondência clara. Mesmo os dados do Parque Fontes do Ipiranga, localizado na mesma região da estação Água Funda do IAG, de onde foram adquiridos os dados de pluviosidade, não apresenta correspondência em todas as estações. Outras informações são necessárias para verificar a influência da precipitação nos índices de vegetação.

O ponto localizado na região de Cajamar apresenta queda acentuada dos dois índices a partir de 2012, permanecendo com valores baixos a partir de então, indicando alteração intensa e permanente da cobertura vegetal. A área de cultivo de eucalipto apresenta oscilações intensas e sucessivas dos dois índices, acima das oscilações de sazonalidade verificada nas áreas que não sofreram alteração de cobertura vegetal, indicando os períodos de corte e crescimento do eucalipto. Já as áreas de pastagem apresentam valores estáveis de NDVI e valores de EVI que acompanham a sazonalidade verificada nas 
demais áreas, porém com valores altos, próximos aos valores verificados em áreas de floresta.

A discriminação de áreas vegetadas e não vegetadas a partir dos índices de vegetação é bastante acurada, porém a aferição da quantidade de vegetação a partir do índice não. Áreas com vegetação arbustiva e herbácea podem apresentar índices mais elevados que áreas florestais.

Tal distinção pode ser evidenciada computando-se os índices de vegetação por classes de LCZ para os anos de 2002, 2010 e 2017.

A substituição da vegetação arbórea densa por ocupação urbana ocorrida em Cajamar pôde ser claramente identificada por meio da análise da série temporal dos índices de vegetação, porém é possível que a substituição de vegetação arbórea por arbustiva não pudesse ser detectada apenas com os índices de vegetação. O exame da $T_{\text {sup }}$ poderia contribuir para a distinção entre as áreas de vegetação arbórea densa e áreas de vegetação arbustiva e herbácea, que apresentam $T_{\text {sup }}$ diurna superior às coberturas vegetais mais densas.

\subsubsection{Análises exploratórias: temperatura superficial, vegetação e renda}

Para o ano de 2010 as temperaturas médias, índices de vegetação e os dados de morfologia (LCZ) foram confrontados com os dados socioeconômicos de renda obtidos pelo Instituo Brasileiro de Geografia e Estatística (IBGE) no Censo Demográfico 2010. Esta análise exigiu que os dados de temperatura e vegetação fossem agregados na mesma escala espacial dos dados socioeconômicos.

Os dados socioeconômicos são disponibilizados pelo IBGE em duas escalas espaciais: área de ponderação e setores censitários. Os setores censitários podem ter dimensões inferiores a de uma quadra urbana, distante da escala de aquisição dos dados do sensor MODIS, e por esse motivo não foram considerados como opção para essa análise.

Foram estudadas três possibilidades de escala espacial: a divisão administrativa em distritos, as áreas de ponderação do CENSO-IBGE e as unidades de informação territorializadas (UITs) definidas pela EMPLASA. A Tabela 11 sintetiza as vantagens e/ou desvantagens de cada possibilidade. 
Tabela 11. Divisões territoriais estudadas.

\begin{tabular}{|c|c|c|}
\hline $\begin{array}{l}\text { DISTRITO. É a divisão } \\
\text { política de maior } \\
\text { familiaridade para gestores } \\
\text { locais, porém nem todos } \\
\text { os municípios da RMSP } \\
\text { possuem distritos. }\end{array}$ & $\begin{array}{l}\text { ÁREAS DE PONDERAÇÃO, IBGE. Possui grande } \\
\text { disponibilidade de dados socioeconômicos. Suas } \\
\text { dimensões e tipos de ocupação variam } \\
\text { consideravelmente. Por representar } 400 \\
\text { domicílios, algumas áreas têm ocupação } \\
\text { homogênea, mas outras são heterogêneas, ou } \\
\text { seja, parte de uma mesma área possui ocupação } \\
\text { concentrada e parte não possui ocupação, como } \\
\text { mostrado na Figura 137. Os arquivos vetoriais } \\
\text { disponibilizados pelo IBGE apresentam } \\
\text { problemas, demandando intenso trabalho de } \\
\text { edição. }\end{array}$ & $\begin{array}{l}\text { UITS, EMPLASA. Unidades criadas pela EMPLASA } \\
\text { baseadas em informações de uso do solo, mas } \\
\text { compatíveis com limites oficiais (município e } \\
\text { distrito) e com os setores censitários. Em certa } \\
\text { medida são semelhantes às áreas de ponderação, } \\
\text { porém, por apresentarem relação com o uso do } \\
\text { solo, sua ocupação é mais homogênea, o que } \\
\text { atende melhor aos interesses desta pesquisa. A } \\
\text { EMPLASA disponibiliza dados socioeconômicos do } \\
\text { CENSO } 2010 \text { já agrupados para as UITs. }\end{array}$ \\
\hline
\end{tabular}

As UITs foram então escolhidas como divisão territorial a ser adotada neste estudo exploratório por compatibilizarem dados socioeconômicos de interesse da pesquisa com uma divisão territorial pautada no uso do solo e, portanto, mais homogênea do ponto de vista da ocupação do território, o que se ajusta melhor aos estudos de $T_{\text {sup }}$.
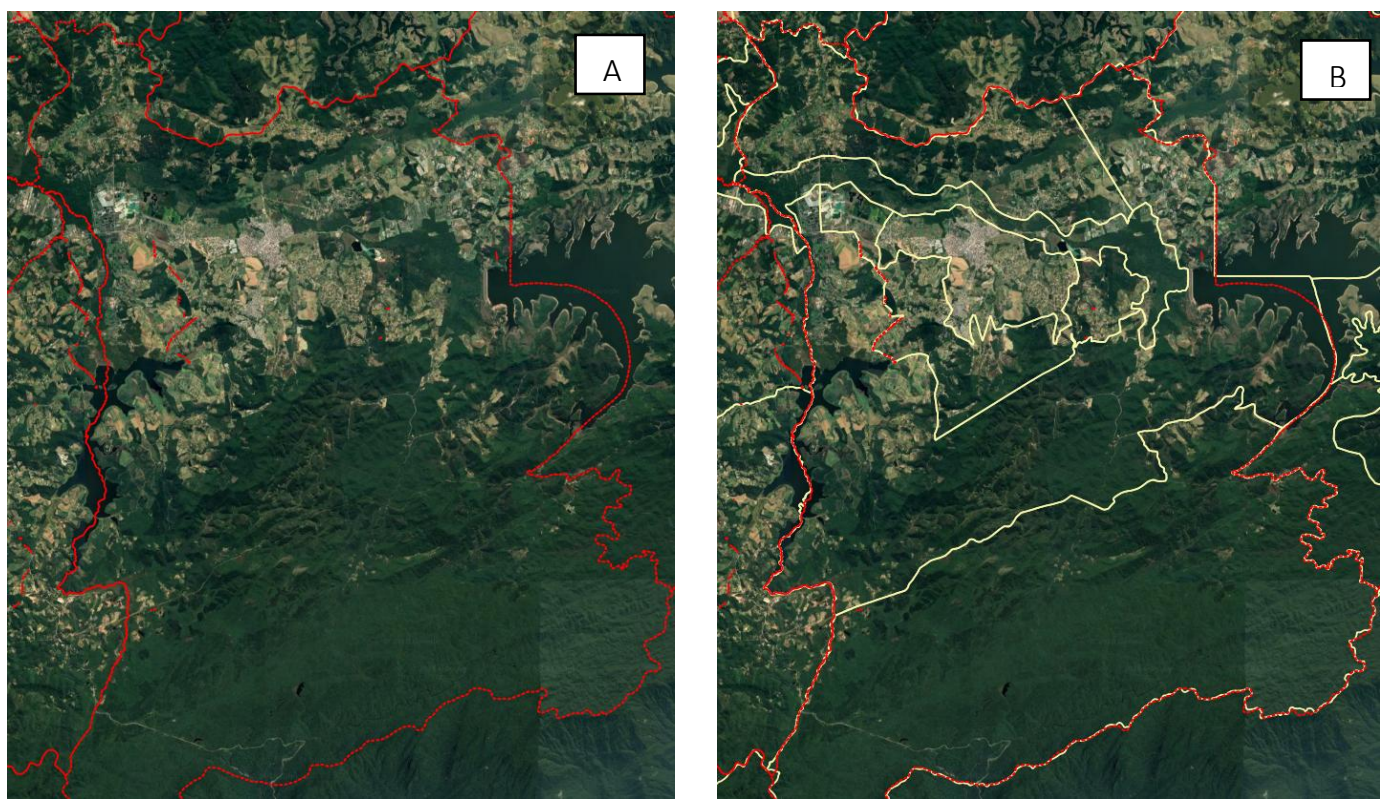

Figura 137. A) Área de ponderação do CENSO IBGE 2010 (vermelho). B) UITS EMPLASA 2010 (amarelo). Município de Biritiba Mirim (RMSP). Fonte: Elaboração própria a partir de dados Google Earth, IBGE (2010) e EMPLASA (2010).

Os resultados das $T_{\text {sup }}$ e do NDVI por UIT é apresentado nas Figuras 138 à 140 e o mapa de renda média do responsável por UIT é apresentado na Figura 141. 


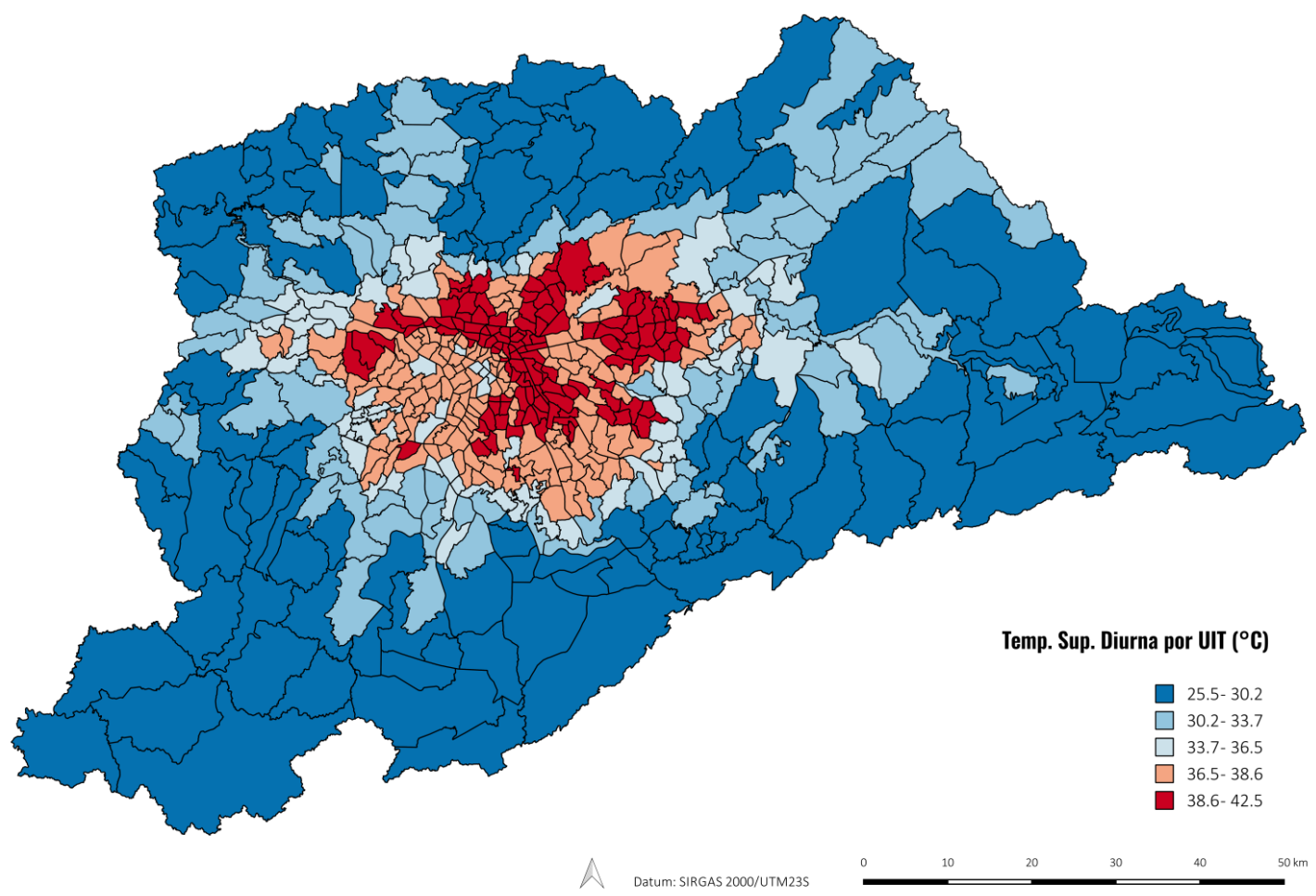

Figura 138. T $T_{\text {sup }}$ diurna por UIT. Estação chuvosa 2009/2010.

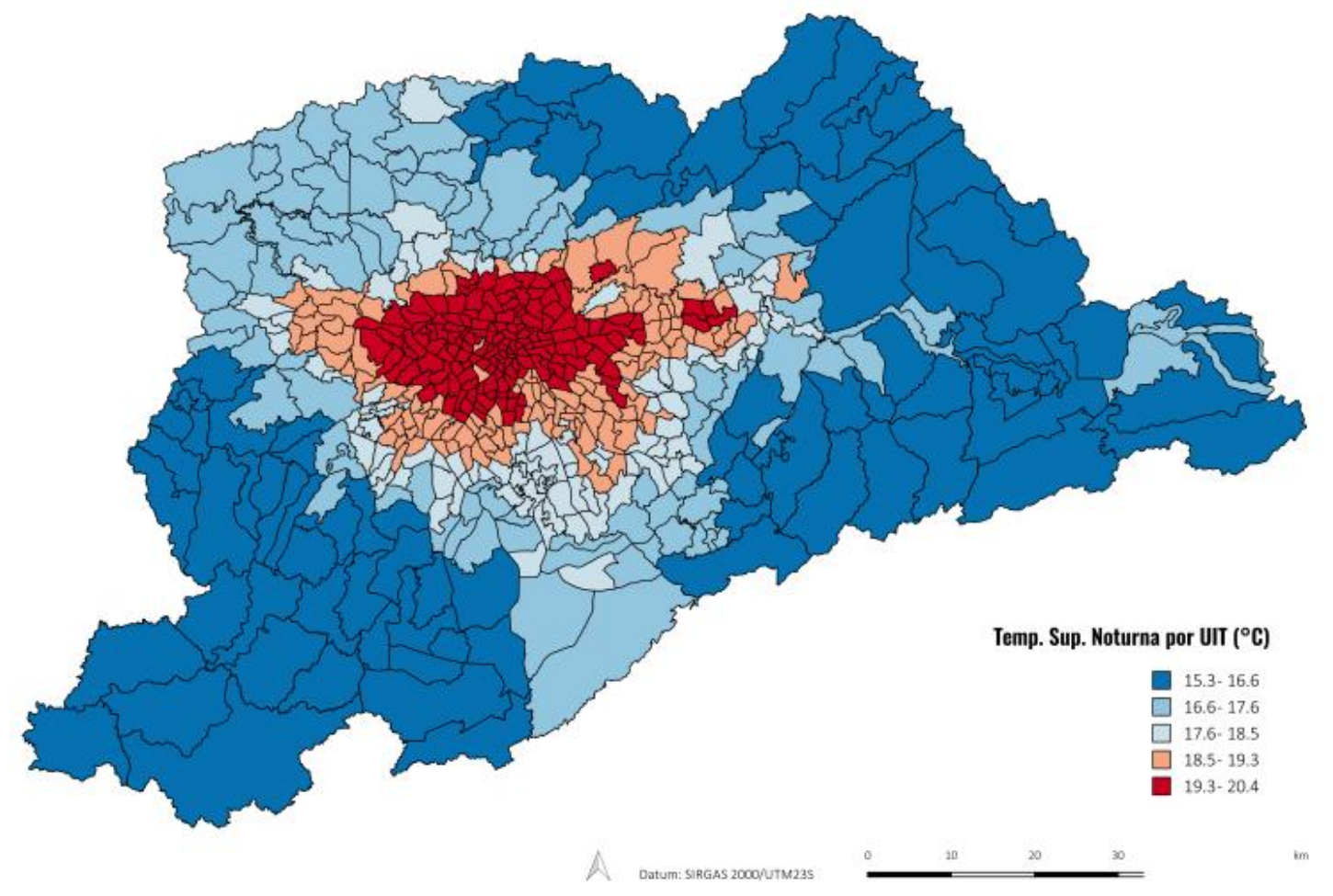

Figura 139. $T_{\text {sup }}$ noturna por UIT. Estação chuvosa 2009/2010. 


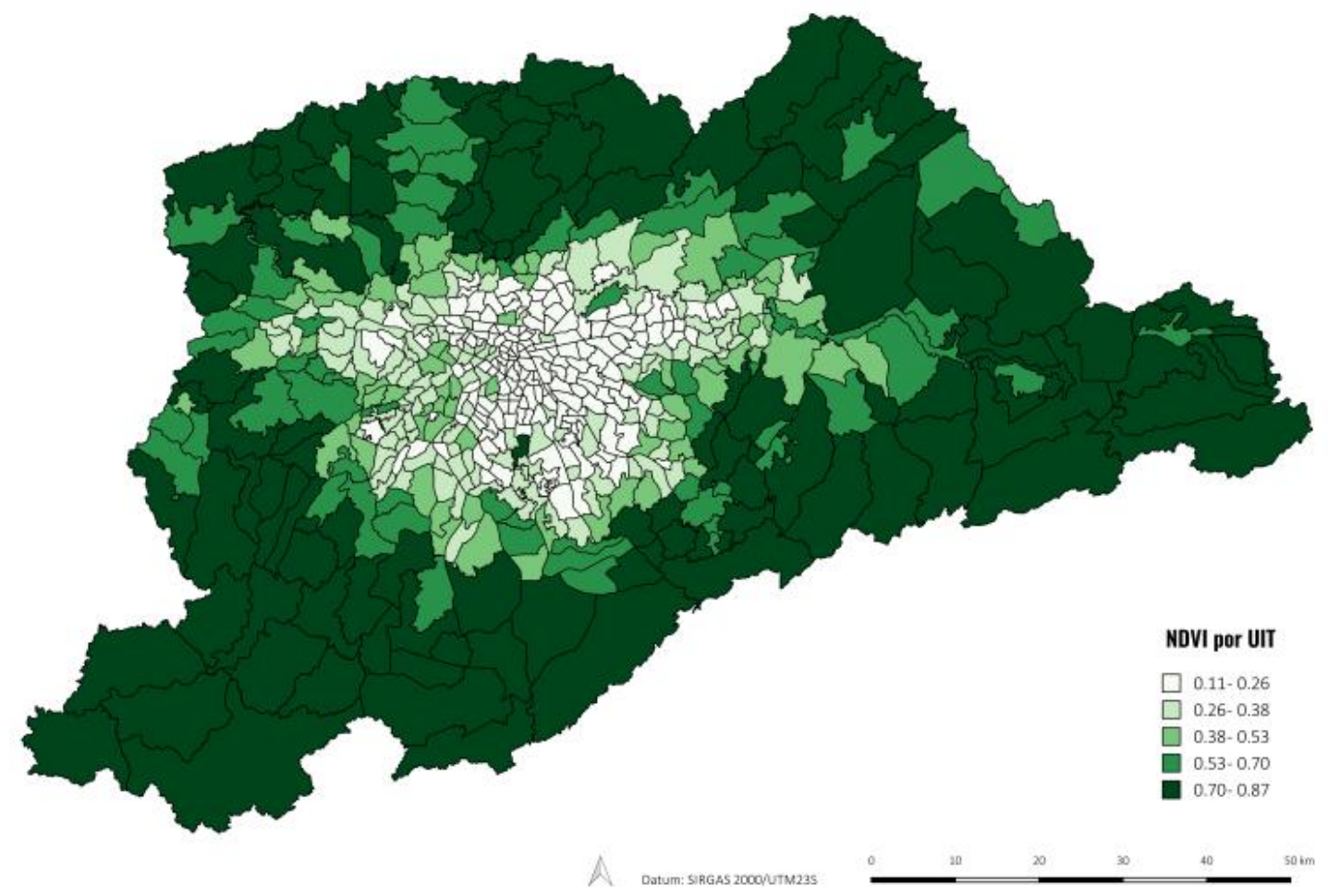

Figura 140. NDVI por UIT. Estação chuvosa 2009/2010.

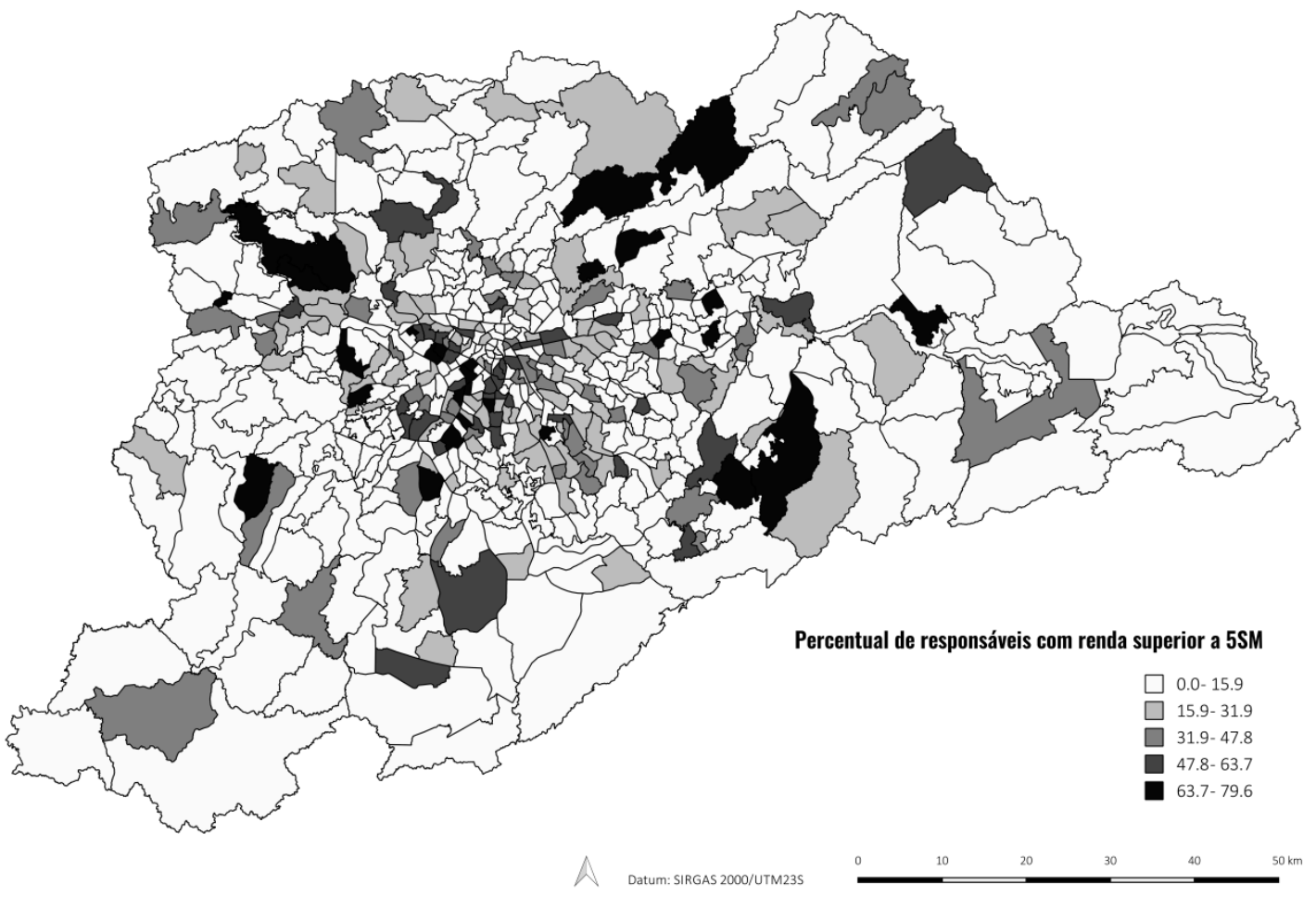

Figura 141. Percentual de pessoas responsáveis pelo domicílio com renda superior a 5 salários mínimos. 
Apesar de utilizar apenas o dado de renda do responsável, essa análise exploratória indicou a correspondência entre UITs com rendimentos mais altos na área urbana principal e UITs com valores elevados de NDVI e valores baixos de $T_{\text {sup }}$ diurna. 


\section{CONSIDERAÇÕES FINAIS E CONCLUSÕES}

A pesquisa aqui apresentada teve como objetivo delimitar a relação entre vegetação, temperatura superficial $\left(\mathrm{T}_{\text {sup }}\right)$ e morfologia urbana, tanto espacial quanto temporalmente.

Foram verificadas temperaturas superficiais diurnas e noturnas mais elevadas nas áreas mais urbanizadas, em comparação com áreas menos urbanizadas, ocupadas de forma esparsa ou dotadas de cobertura vegetal, para todo o período analisado. Esses resultados corroboram pesquisas anteriores, tanto para a RMSP quanto para outras localidades (ALAVIPANAH et al., 2015; FUCKNER; MORAES; FLORENZANO, 2009; IMHOFF et al., 2010; LOMBARDO, 1985; ROTH; OKE; EMERY, 1989; SOUSA; FERREIRA, 2012), sendo que a diferença de temperatura entre áreas urbanizadas e não urbanizadas é maior no período diurno.

Porém, apesar de mais aquecida, a área urbanizada não apresenta $T_{\text {sup }}$ homogênea. $A$ distinção dos tipos morfológicos dessas áreas evidencia que as áreas verticalizadas compactas, com poucos espaços livres e pouca cobertura vegetal, apresentam $T_{\text {sup }}$ noturna superior às outras morfologias urbanas, característica compatível com o padrão de ilha de calor de superfície.

Durante o dia, porém, as áreas verticalizadas apresentam $T_{\text {sup }}$ inferior às áreas horizontais compactas, com poucos espaços livres e pouca cobertura vegetal, indicando a influência da sombra dos edifícios nos padrões de temperaturas superficiais diurnas.

Entre as tipologias construtivas analisadas por meio das classificações LCZ para os anos de 2002, 2010 e 2017, aquelas com maior quantidade de espaços livres e cobertura vegetal são as que apresentam menores temperaturas superficiais diurnas.

A correlação entre a $T_{\text {sup }}$ e os dois índices de vegetação, NDVI e EVI, é alta e negativa para todo o período analisado, mantendo-se elevada tanto nas estações com temperaturas superficiais acima da média do período como naquelas com precipitação abaixo da média do período, indicando o papel da vegetação tanto na atenuação das temperaturas superficiais na RMSP quanto sua possível resiliência às situações extremas de temperaturas elevadas e baixa precipitação. 
As análises temporais realizadas para os dados do sensor MODIS mostraram-se fortemente dependentes da escala de aquisição dos dados e do tratamento estatístico empregado. Para a vegetação, com resolução espacial de $250 \mathrm{~m}$, os resultados evidenciaram tanto as dinâmicas agrícolas do extremo leste da RMSP, quanto as dinâmicas decorrentes da supressão da vegetação pela expansão urbana de alta e baixa renda, e da execução de grandes obras viárias. As análises da $T_{\text {sup }}$ diurna, com resolução de $1 \mathrm{~km}$, evidenciaram alterações como a conversão de áreas arborizadas em áreas urbanas residenciais e industriais, bem como a implantação de pavimentação asfáltica, sugerindo serem desejáveis a utilização de outros tipos de materiais para pavimentação viária (há diversas alternativas conhecidas na literatura como 'cool pavements') (SANTAMOURIS; KOLOKOTSA, 2016) e a compatibilização com a arborização para sombreamento das vias e calçadas.

Portanto, as áreas vegetadas apresentaram $T_{\text {sup }}$ inferior às áreas não vegetadas ao longo de todo o período analisado, sendo que a supressão da vegetação acarretou aumento de $\mathrm{T}_{\text {sup, }}$ resultados que comprovam as hipóteses do trabalho e condizem com aqueles verificados nas referências bibliográficas.

Os resultados indicam também que os dois índices de vegetação utilizados apresentam boa sensibilidade para monitorar variações espaciais e temporais da vegetação urbana, sendo que o NDVI apresenta valores mais elevados que o EVI, conforme Huete et al. (2002). Ademais, verificou-se que a separação entre diferentes tipologias vegetais na RMSP apresentou melhores resultados com o NDVI; porém, a sazonalidade da vegetação é melhor captada pelo EVI. Estudos com imagens de melhor resolução espacial poderiam confirmar as diferenças entre os índices para estudos urbanos.

Os resultados revelam ainda o papel do desenho urbano nas dinâmicas termais da superfície. A morfologia urbana e a quantidade de vegetação influenciam a $T_{\text {sup }}$ que, por sua vez, modula a $T_{a r}$ nas camadas mais baixas da atmosfera (VOOGT; OKE, 2003). Isso indica que a proposição de estratégias para a mitigação e adaptação aos fenômenos de aquecimento urbano deverão considerar a forma de ocupação do território, a tipologia edificada e a vegetação intra-urbana, especialmente em um cenário de mudanças climáticas e eventos extremos. 
O dinamismo das temperaturas superficiais exige dados com alta resolução temporal para que se possa realizar a caracterização de seus padrões de distribuição espacial, bem como examinar suas tendências. No SR, atualmente, a alta resolução temporal implica baixa resolução espacial. As resoluções espaciais de $1 \mathrm{~km}$ ou $250 \mathrm{~m}$ adotadas no presente trabalho podem parecer distantes da escala do arquiteto, especialmente para a tomada de decisão. Porém, oferecem a possibilidade de uma visão do conjunto, que, nas palavras de Milton Santos permitem "um enfoque totalizador e o reconhecimento da hierarquia dos fatores" (SANTOS, M, 1985, p.11).

As imagens termais podem ser uma forma de expressão visual poderosa para comunicar aos planejadores, tomadores de decisão e à sociedade, conhecimentos sobre clima urbano, na expectativa de que estes possam ser incorporados com vistas a uma ocupação urbana sensível às questões climáticas e ambientais.

Exemplos da aplicação direta de resultados do SR termal e da vegetação em políticas públicas podem ser vistos, por exemplo, na região metropolitana de Toronto, no Canadá. A partir do cruzamento entre dados de cobertura arbórea existente, $T_{\text {sup }}$ e densidade populacional, foi desenvolvido um índice de prioridade para arborização, que busca identificar áreas com alta densidade populacional e baixa cobertura arbórea per capita, com espaço disponível para o plantio (Figura 142).

A complexa realidade das cidades brasileiras, porém, impõe desafios à inserção e à preservação da vegetação urbana que vão além das questões técnicas e envolvem a compreensão das 'relações entre os processos sociais e o suporte físico' ${ }^{46}$, bem como dos interesses em disputa no território urbano. Os resultados aqui apresentados configuram uma nova camada de informações para a análise de tais relações. Nesse sentido, é importante destacar as diferenças de compreensão da escala dos pixels e das pessoas (LIVERMAN et al., 1998). A relação entre a $T_{\text {sup }}$ medida pelo satélite e a sensação que ela provoca no individuo inserido no território deve ser examinada com cautela, considerando, sobretudo, o tipo de ocupação territorial.

${ }^{46}$ QUEIROGA, 2016. 

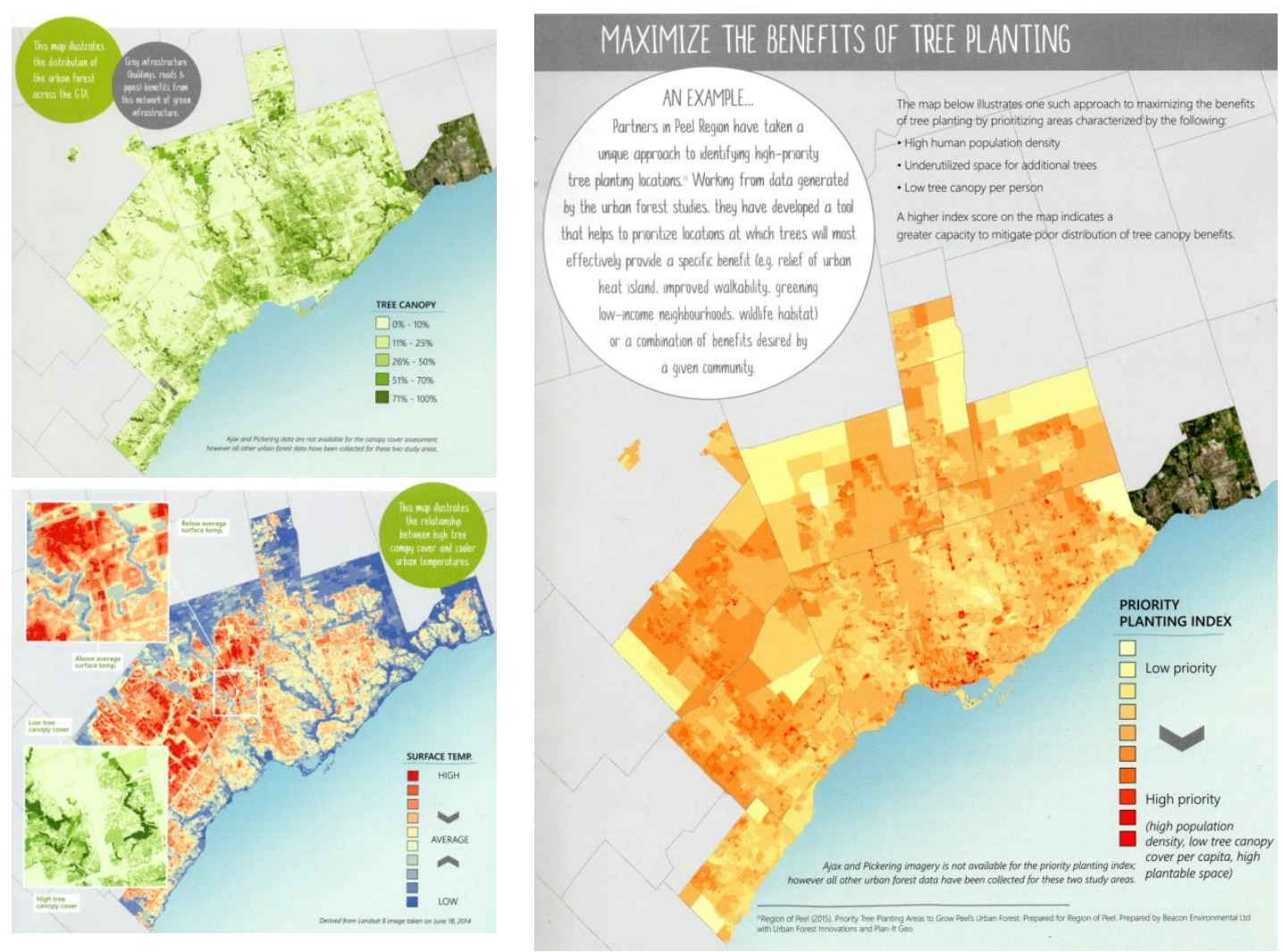

Figura 142. A) Mapa de cobertura arbórea. B) Mapa de $T_{\text {sup }}$ diurna. C) Índice de prioridade para plantio. Região Metropolitana de Toronto, Canadá. Fonte: (EASTWOOD et al., 2016).

Pixels com valores elevados de $T_{\text {sup }}$ noturna nas áreas centrais verticalizadas da RMSP não significam, necessariamente, que as pessoas que ocupam estes locais estejam em desconforto térmico. A alta inércia térmica de algumas edificações nessas regiões faz com que o calor recebido e acumulado em sua envoltória durante o dia seja dissipado no período noturno, muitas vezes sem conseguir atravessar a envoltória e atingir o ambiente interno.

Já a periferia, densamente ocupada por edificações cujas coberturas possuem pouca massa e baixa resistência à transmissão do calor, pode enfrentar desconforto térmico tanto no período diurno quanto noturno. A dissipação do calor transmitido para o interior das edificações durante o dia dependerá de condições adequadas de ventilação e, mesmo que essas regiões mostrem-se menos aquecidas nas imagens noturnas, a real condição de conforto dependerá da tipologia construtiva de cada edifício. 
Porém, nos espaços abertos, a interpretação das imagens termais é mais direta, ou seja, áreas com altas temperaturas superficiais revestidas por materiais inertes, possivelmente apresentam mais tempo em desconforto térmico se comparadas às demais.

As áreas ocupadas por edifícios altos e espaçados, representadas pelo LCZ 4 (Alto-aberto) nos mapas de morfologia urbana, vistas a partir da escala do pixel, aparentam reunir boas características compatibilizando verticalização e possibilidade de adensamento, maior quantidade de vegetação, combinação de sombra dos edifícios com grandes áreas arborizadas, evitando-se a elevação das temperaturas diurnas, e adequado espaçamento entre as edificações, permitindo a dissipação do calor acumulado na envoltória. Visto a partir da escala do indivíduo é, na RMSP, expressão da desigualdade e da segregação socioespacial. Não por conta necessariamente de sua morfologia, mas por conta das relações sociais que a geraram. Em uma cidade onde o solo é caro, sobretudo nas áreas dotadas de infraestrutura urbana, o espaço livre arborizado se torna um luxo. Na escala do individuo, essas áreas apresentam edifícios altos isolados em lotes murados, sem diálogo com a rua, empobrecendo o espaço livre público e confinando as pessoas às suas vidas privadas (Figura 143).
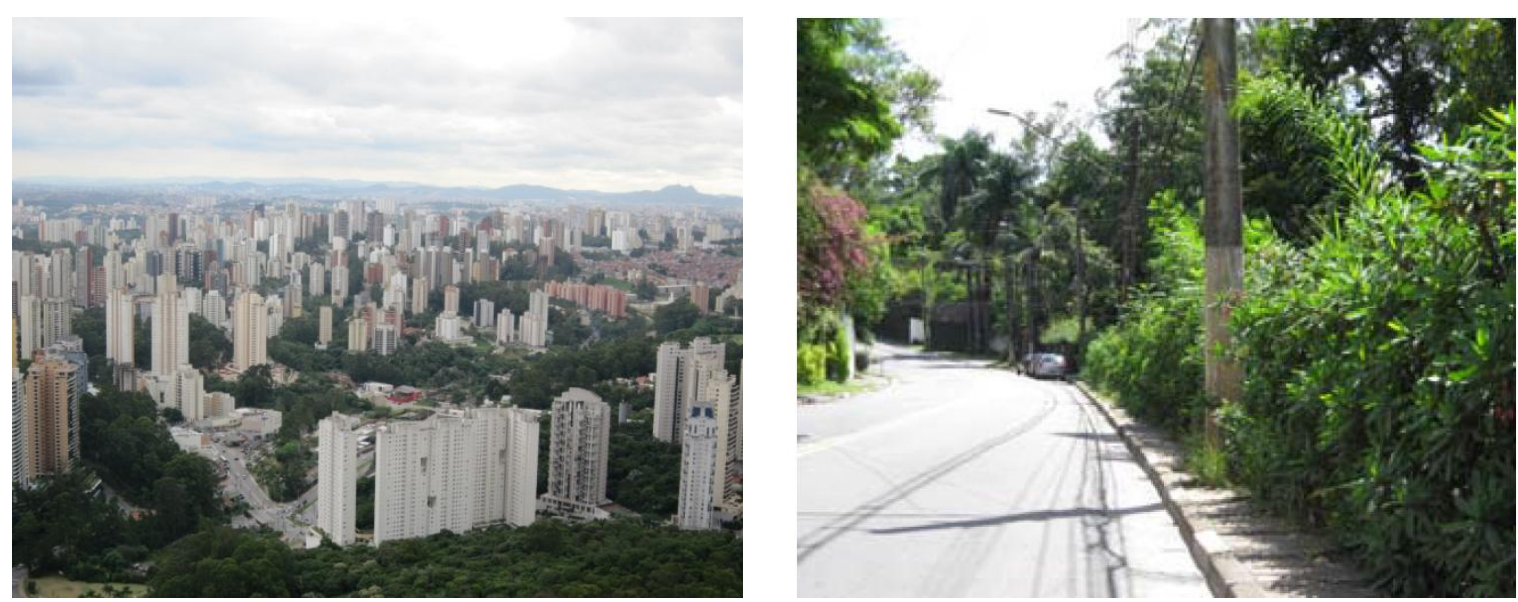

Figura 143. Vila Andrade, São Paulo. A) Vista aérea. B) Calçada com dimensões insuficientes e vegetação inadequada. Fonte: Imagens da autora.

A partir dos resultados apresentados por este trabalho sugerem-se alguns possíveis desdobramentos para trabalhos futuros: 
- O detalhamento da relação entre vegetação, morfologia urbana, temperatura de superfície e temperatura do ar para a escala microclimática em áreas nas quais este trabalho verificou temperaturas superficiais acima ou abaixo da média;

- O preenchimento das séries temporais dos índices de vegetação e das temperaturas de superfície para possibilitar análises mais completas, permitindo explorar a previsão da alteração de uma variável em função da outra;

- O exame da relação entre as temperaturas de superfície medidas por sensoriamento remoto e o conforto térmico no interior das edificações, relacionando as tipologias construtivas e suas respostas termais;

- A aplicação do método utilizado neste trabalho para outras áreas urbanas e/ou para o desenvolvimento de um sistema de monitoramento on line contínuo que acompanhe as alterações da temperatura e dos índices de vegetação a partir dos dados MODIS.

Por fim, espera-se que os resultados aqui apresentados possam oferecer argumentos técnicos e científicos para a inserção e para a preservação da vegetação em áreas urbanas, contribuindo também para aprofundar a compreensão da sociedade em relação aos papéis da vegetação e sua importância para a qualidade de vida urbana, especialmente em um cenário de alterações climáticas e eventos extremos. 


\section{Referências bibliográficas}

ACERO, J. A.; GONZÁLEZ-ASENSIO, B. Influence of vegetation on the morning land surface temperature in a tropical humid urban area. Urban Climate, v. 26, p. 231-243, 2018.

ADAMS, M. P.; SMITH, P. L. A systematic approach to model the influence of the type and density of vegetation cover on urban heat using remote sensing. Landscape and Urban Planning, v. 132, p. 47-54, 2014. ALAVIPANAH, S. et al. The role of vegetation in mitigating urban land surface temperatures: A case study of Munich, Germany during the warm season. Sustainability (Switzerland), v. 7, n. 4, p. 4689-4706, 2015.

ALBERTI, Marina. Advances in Urban Ecology: Integrating Humans and Ecological Processes in Urban Ecosystems. Springer-Verlag, 2008.

ALEXANDER, P. J. et al. Land surface temperature climatology over urban surfaces : A blended approach. In: 2017 Joint Urban Remote Sensing Event (JURSE). Anais...Dubai: 2017.

ASSIS, E. S. DE. A abordagem do clima urbano e aplicações no planejamento da cidade: reflexões sobre uma trajetória. In: VIII Encontro Nacional sobre Conforto no Ambiente Construído. Anais... Maceió, 2005, p. 92101.

BARBETTA, P. A. Estatística Aplicada às Ciências Sociais. Florianópolis: Ed. da UFSC, 1994.

BARROS, H. R.; LOMBARDO, M. A. A ilha de calor urbana e o uso e cobertura do solo em São Paulo-SP.

Geousp - Espaço e Tempo, v. 20, n. 1, p. 160-177, 2016.

BARSI, J. A.; BARKER, J. L.; SCHOTT, J. R. An Atmospheric Correction Parameter Calculator for a single thermal band earth-sensing instrument. In: IEEE International Geoscience and Remote Sensing Symposium. Anais... Toulouse, 2003, p. 2-4.

BRASIL. Lei Complementar n 14, de 8 de junho de 1973. Estabelece as Regiões Metropolitanas de São Paulo, Belo Horizonte, Porto Alegre, Recife, Salvador, Curitiba, Belem e Fortaleza. Diário Oficial da União: Brasília, DF, p. 5585, col. 1, 11 jun. 1973.

BECHTEL, B. et al. Mapping Local Climate Zones for a Worldwide Database of the Form and Function of Cities. ISPRS International Journal of Geo-Information, v. 4, n. 1, p. 199-219, 2015. 
BILIBIO, M. A. A Clínica Gestáltica e a Crise Ambiental: em busca de uma Psicoterapia para a Desconexão Ser Humano-Natureza. Revista de Psicologia do Instituto Gestalt de São Paulo., n. 6, p. 11-16, 2011.

BOWLER, D. E. et al. Urban greening to cool towns and cities: A systematic review of the empirical evidence. Landscape and Urban Planning, v. 97, n. 3, p. 147-155, 2010.

CAI, M. et al. Investigating the relationship between local climate zone and land surface temperature using an improved WUDAPT methodology - A case study of Yangtze River Delta, China. Urban Climate, v. 24, p. 485$502,2018$.

CAMPBELL, J. B.; WYNNE, R. H. Introduction to Remote Sensing. 5th. ed. New York: The Guilford Press, 2011. CENTRO DE ESTUDOS DA METRÓPOLE (CEM). Base de dados. Contornos perimétricos e dados dos 162 distritos da RMSP, obtidos conforme quadro político-administrativo de 01 jan. 2001. Edição: junho de 2007. Disponível em: http://web.fflch.usp.br/centrodametropole/. Acesso: 27 abr. 2016.

CHATZIDIMITRIOU, A.; CHRISSOMALLIDOU, N.; YANNAS, S. Microclimate modifications of an urban street in northern Greece. In: PLEA 2005 - Passive and Low Energy Architecture. Anais...Beirut: 2005

CHIANN, C.; SOARES, M.; ALVES, V. S. M. Relatório de análise estatística sobre o projeto: “O impacto da supressão da vegetação no microclima urbano". São Paulo: [s.n.].

COUTTS, A. Green infrastructure for cities: It's all about trees. Urban Climate News n.57, p. 7-12, set. 2015.

COUTTS, A. M. et al. Thermal infrared remote sensing of urban heat: Hotspots, vegetation, and an assessment of techniques for use in urban planning. Remote Sensing of Environment, v. 186, p. 637-651, 2016.

CRISP - Centre for Remote Imaging, Sensing, \& Processing. s.n.t. 1 imagem color. Disponível em: <http://www.crisp.nus.edu.sg/ research/tutorial/intro.htm>. Acesso em: 01 dez. 2015

DESENVOLVIMENTO RODOVIÁRIO S/A (DERSA). Rodoanel Mário Covas. São Paulo: DERSA, 2019. Disponível em: http://www.dersa.sp.gov.br/empreendimentos/rodoanel-mario-covas/. Acesso em: 19 abr. 2019.

DIDAN, K.; MUNOZ, A. B.; HUETE, A. MODIS Vegetation Index User's Guide ( MOD13 Series ). 2015.

DOUSSET, B. et al. Satellite monitoring of summer heat waves in the Paris metropolitan area. International Journal of Climatology, v. 31, n. 2, p. 313-323, 2011. 
DUARTE, D. H. O impacto da vegetação no microclima em cidades adensadas e seu papel na adaptação aos fenômenos de aquecimento urbano. Contribuições a uma abordagem interdisciplinar. 2015. Tese (LivreDocência) - Faculdade de Arquitetura e Urbanismo, Universidade de São Paulo, São Paulo, 2015.

DUARTE, D. H. S. et al. The impact of vegetation on urban microclimate to counterbalance built density in a subtropical changing climate. Urban Climate, v. 14, p. 224-239, 2015.

DUARTE, D. H. S. Vegetation and climate-sensitive public places. In: EMMANUEL, R. (Ed.). . Urban climate challenges in the Tropics: rethinking planning and design opportunities. Glasgow: Imperial College Press, 2016. EASTWOOD, M. et al. State of the urban forest in the greater Toronto Area. Toronto: Green Infrastructure Ontario Coalition, 2016.

ECKERT, S. et al. Trend analysis of MODIS NDVI time series for detecting land degradation and regeneration in Mongolia. Journal of Arid Environments, v. 113, p. 16-28, 2015.

EMMANUEL, R. An Urban Approach to Climate-Sensitive Design. Strategies for the Tropics. New York: Spon Press, 2005.

EMMANUEL, R. Urban Heat Islands and sustainable urbanity: An application agenda for tropical mega-cities. In: HEBBERT, M.; JANKOVIC, V.; WEBB, B. (Eds.). . City Weathers. Meteorology and urban design 1950-2010. Manchester: Manchester Architecture Research Centre, 2011, p. 75-80.

EMPRESA PAULISTA DE PLANEJAMENTO METROPOLITANO (EMPLASA). Projeto de Atualização Cartogáfica do Estado de São Paulo. São Paulo: EMPLASA, 2010. 1 imagem ortorretificada, color. Levantamento aerofotogramétrico 2010/2011. Disponível em: http://datageo.ambiente.sp.gov.br. Acesso em: 17 set. 2018. EPA - ENVIRONMENTAL PROTECTION AGENCY. Protecting Water Quality from Urban Runof. U.S. Washington: Environmental Protection Agency, 2003. Disponível em: <http://cfpub.epa.gov/npstbx/files/NPS_Urbanfacts_final.pdf>.

ERELL, E. The application of urban climate research in the design of cities. Advances in Building Energy Research, v. 2, n. 1, p. 95-121, 2008.

ERELL, E.; PEARLMUTTER, D.; WILLIAMSON, T. Urban Microclimate: Designing the Spaces Between Buildings. London: Eathscan, 2011.

ESAU, I. et al. Trends in normalized difference vegetation index (NDVI) associated with urban development in 
northern West Siberia. Atmospheric Chemistry and Physics, v. 16, n. 15, p. 9563-9577, 2016.

FERREIRA, L. S. Manejo da vegetação na cidade de São Paulo: supressão e compensação. O caso do distrito da Vila Andrade. São Paulo. Dissertação (Mestrado) - Faculdade de Arquitetura e Urbanismo da Universidade de São Paulo (FAUUSP). São Paulo. 2012.

Ferreira, L. S. et al. Mapping Local Climate Zones for São Paulo Metropolitan Area, Brazil. In: WUDAPT LAUNCH IN HONG KONG. Applications of WUDAPT Products, Hong Kong, 5-6 Dez., 2016.

FERREIRA, L. S. et al. Mapping Local Climate Zones for São Paulo Metropolitan Region: a comparison between the local climate zone map and two other maps. In: Passive and Low Energy Architecture (PLEA) Proceedings. Anais...Edimburgh: 2017

FERREIRA, L. S.; DUARTE, D. H. S. Land surface temperature, vegetation cover and urban morphology over different local climate zones in São Paulo Metropolitan Region. In: 10th International Conference on Urban Climate/ 14th Symposium on the Urban Environment. Anais...New York: 2018. Disponível em: <https://ams.confex.com/ams/ICUC10/meetingapp.cgi/Paper/341372>.

FLORENZANO, T. G. Iniciação em Sensoriamento Remoto. São Paulo: Oficina de Textos, 2007.

FLORES R., J. L.; PEREIRA FILHO, A. J.; KARAM, H. A. Estimation of long term low resolution surface urban heat island intensities for tropical cities using MODIS remote sensing data. Urban Climate, v. 17, p. 32-66, 2016.

FROTA, A.; SCHIFFER, S. R. Manual de conforto térmico. 5ed. São Paulo: Studio Nobel, 2001.

FUCKNER, M. A.; MORAES, E. C.; FLORENZANO, T. G. Processamento de dados multiespectrais termais aplicados à análise espaço-temporal dos padrões de temperatura da superfície nas Regiões Metropolitanas de São Paulo e Rio de Janeiro. In: Anais XIV Simposio Brasileiro de Sensoriamento Remoto. Anais...Natal, 2009 GELETIČ, J.; DOBROVOLNY, P.; LEHNERT, M. Statistical analyses of land surface temperature in local climate zones: Case study of Brno and Prague (Czech Republic). In: 2017 Joint Urban Remote Sensing Event (JURSE). Anais...Dubai: 2017, p. 1-4.

GELETIČ, J.; LEHNERT, M.; DOBROVOLNÝ, P. Land surface temperature differences within local climate zones, Based on two central European cities. Remote Sensing, v. 8, n. 10, p. 1-18, 2016.

GIRIDHARAN, R. et al. Lowering the outdoor temperature in high-rise high-density residential developments of coastal Hong Kong: The vegetation influence. Building and Environment, v. 43, n. 10, p. 1583-1595, 2008. 
GIVONI, B. Climate considerations in building and urban design. New York: J. Wiley \& Sons, 1998.

GOOGLE. Google Earth Pro V.7.3.2 5491. [Mountain View, CA: Google, 2018]. Disponível em:

https://www.google.com/intl/pt-BR/earth/versions/\#earth-pro. Acesso: jan. 2018.

GUO, Y. et al. Quantifying excess deaths related to heatwaves under climate change scenarios: A multicountry time series modelling study. PLoS Medicine, v. 15, n. 7, p. 1-17, 2018.

HANG, H. T.; RAHMAN, A. Characterization of thermal environment over heterogeneous surface of National Capital Region (NCR), India using LANDSAT-8 sensor for regional planning studies. Urban Climate, v. 24, n. October 2017, p. 1-18, 2018.

HEBBERT, M. Climatology for city planning in historical perspective. Urban Climate, v. 10, n. P2, p. 204-215, 2014.

HEBBERT, M.; JANKOVIC, V. City Weathers. In: HEBBERT, M.; JANKOVIC, V.; WEBB, B. (Eds.). . City Weather, Meteorology and Urban Design 1950-2010. Manchester: Manchester Architecture Research Centre, 2011. p. 9-14.

HIJMANS, R. J. raster: Geographic Data Analysis and Modeling. R package version 2.8-4., 2018. Disponível em: <https://cran.r-project.org/package=raster>.

HONJO, T.; TAKAKURA, T. TSUYOSHI HONJO and TADASHI TAKAKURA Department of Agricultural Engineering, University of Tokyo, Hongo, Bunkyo-ku, Tokyo (Japan). Energy and Buildings, v. 15-16, p. 443-446, 1990.

HOUGH, M. Naturaleza y ciudad. Planificación Urbana y Procesos Ecológicos. Barcelona: Gustavo Gili, 1998.

$\mathrm{HU}, \mathrm{Y}$;; JIA, G. Influence of land use change on urban heat island derivedfrom multi-sensor data. International Journal of Climatology, v. 30, n. 9, p. 1382-1395, 2010.

HUETE, A. et al. Overview of the radiometric and biopyhsical performance of the MODIS vegetation indices. Remote Sensing of Environment, v. 83, p. 195-213, 2002a.

HUETE, A. et al. Overview of the radiometric and biophysical performance.pdf. Remote Sensing of Environment, v. 83, p. 195-213, 2002b.

IMHOFF, M. L. et al. Remote sensing of the urban heat island effect across biomes in the continental USA. Remote Sensing of Environment, v. 114, n. 3, p. 504-513, 2010. 
INSTITUTO BRASILEIRO DE GEOGRAFIA E ESTATÍSTICA - IBGE. Censo Demográfico 2010. [S.I.]: IBGE, 2010. Disponível em: <www.censo2010.ibge.gov.br>.

INSTITUTO BRASILEIRO DE GEOGRAFIA E ESTATÍSTICA (IBGE). IBGE divulga as Estimativas de População dos municípios para 2018. Agência IBGE Notícias, [Rio de Janeiro], 29 ago. 2018. Disponível em:

https://agenciadenoticias.ibge.gov.br/agencia-sala-de-imprensa/2013-agencia-de-noticias/releases/22374ibge-divulga-as-estimativas-de-populacao-dos-municipios-para-2018. Acesso em: 19 fev. 2019.

INSTITUTO GEOLÓGICO DO ESTADO DE SÃO PAULO (IG). Imagem Orbital Ortorretificada da Região Metropolitana de São Paulo. São Paulo: IG, 2002. 1 imagem de satélite, color. Satélite IKONOS. Disponível em: http://datageo.ambiente.sp.gov.br. Acesso em: 17 set. 2018.

IPCC. INTERGOVENMENTAL PANEL ON CLIMATE CHANGE (IPCC). Climate Change 2014: Impacts, Adaptation, and Vulnerability. IPCC Working Group II Contribution to AR5. 2014.

JÁUREGUI, E. Tropical Urban Climatology at the turn of the Millennium - an overview. In: International Congress of Biometeorology and International Conference on Urban Climatology. Selected Papers. Anais...Sydney: World Meteorological Organization, 1999

JENERETTE, G. D. et al. Regional relationships between surface temperature, vegetation, and human settlement in a rapidly urbanizing ecosystem. Landscape Ecology, v. 22, n. 3, p. 353-365, 2007.

JENSEN, J. R. Sensoriamento remoto do ambiente. Uma perspectiva em recursos terrestres. São José dos Campos: Parêntese Editora, 2009.

JOHANSSON, E.; EMMANUEL, R. The influence of urban design on outdoor thermal comfort in the hot, humid city of Colombo, Sri Lanka. International Journal of Biometeorology, v. 51, n. 2, p. 119-133, 2006.

KATZSCHNER, L. Urban climate in dense cities. In: NG, E. (Ed.). . Designing high-densities cities for social and environmental sustainability. London: Earthscan, 2010. p. 71-78.

KRÜGER, E. L.; MINELLA, F. O.; RASIA, F. Impact of urban geometry on outdoor thermal comfort and air quality from field measurements in Curitiba, Brazil. Building and Environment, v. 46, n. 3, p. 621-634, 2011.

LEUZINGER, S.; VOGT, R.; KÖRNER, C. Tree surface temperature in an urban environment. Agricultural and Forest Meteorology, v. 150, n. 1, p. 56-62, 2010.

LI, Y. et al. Local cooling and warming effects of forests based on satellite observations. Nature Communications, v. 6, p. 1-8, 2015. 
LI, Z. L. et al. Satellite-derived land surface temperature: Current status and perspectives. Remote Sensing of Environment, v. 131, p. 14-37, 2013.

LIN, Z.; XU, H. A study of Urban heat island intensity based on "local climate zones": A case study in Fuzhou, China. 4th International Workshop on Earth Observation and Remote Sensing Applications, EORSA 2016 Proceedings, n. Ur I, p. 250-254, 2016.

LIVERMAN, D. et al. (ed.). People and pixels. Linking Remote Sensing and Social Science. Washington: National Academies Press, 1998.

LOCOSSELLI, G. M. et al. Effects of climate and air pollution on the growth of urban trees. In: 10th World Dendro Conference. Anais...Thimphu: Ugyen Wangchuck Institute for Conservation and Environmental Research, 2018

LOMBARDO, M. A. Ilha de Calor nas Metrópoles. O exemplo de São Paulo. São Paulo: Hucitec, 1985. LOMBARDO, M. A. et al. O USO DE GEOTECNOLOGIAS NA ANÁLISE DE DA ILHA DE CALOR, índice de vegetação e uso da terra. Revista Geonorte, v. 2, n. 5, p. 520-529, 2012.

LOUV, R. Last Child in the Woods: saving our children from Nature-Deficit Disorder. North Carolina: Algonkin Books of Chapel Hill, 2006.

MAGNOLI, M. M. Espaços Livres e Urbanização: uma introdução a aspectos da paisagem metropolitana.1992. Tese (Livre-Docência) - Faculdade de Arquitetura e Urbanismo, Universidade de São Paulo, São Paulo, 1982. MASSON, V. et al. Urban Climate, Human behavior \& Energy consumption : from LCZ mapping to simulation and urban planning (the MapUCE project). In: 9th International Conference on Urban Climate.

Anais...Toulouse, 2015.

MENDES, F. H. et al. Potencialidades no uso de imagens termais aéreas de alta resolução da superfície urbana como ferramenta para mapear o campo térmico. Scientia Plena, v. 11, n. 9, 2015.

MENDES, I. Efeitos do uso e cobertura do solo sobre o conforto higrotérmico. 2012. Dissertação (Mestrado) Escola Superior de Agricultura "Luiz de Queiroz", Universidade de São Paulo, Piracicaba, 2012.

MILDREXLER, D. J.; ZHAO, M.; RUNNING, S. W. A global comparison between station air temperatures and MODIS land surface temperatures reveals the cooling role of forests. Journal of Geophysical Research:

Biogeosciences, v. 116, n. 3, p. 1-15, 2011. 
MILLS, G. Urban Climatology and Urban Design. In: International Congress of Biometeorology and International Conference on Urban Climatology. Selected Papers. Anais...Sydney: World Meteorological Organization, 1999

MILLS, G. Urban climatology: History, status and prospects. Urban Climate, v. 10, n. P3, p. 479-489, 2014.

MODIS land team. Validation. Status for: Vegetation Indices (MOD13). 2018a. Disponível em:

https://landval.gsfc.nasa.gov/ProductStatus.php?ProductID=MOD13. Acesso em: jan. de 2018.

MODIS land team. Validation. Status for: Land Surface Temperature and Emissivity (MOD11).2018b. Disponível em: https://landval.gsfc.nasa.gov/ProductStatus.php?ProductID=MOD11. Acesso em: jan. de 2018.

MONTEIRO, L.; ALUCCI, M. Proposal of an outdoor index: empirical verification in the sub-tropical climate. In: PLEA 2011 - Passive and Low Energy Architecture. Anais...Louvain-la-neuve: 2011.

MORETTIN, P. A.; TOLOI, C. M. C. Análise de Séries Temporais. 2a edição ed. São Paulo: Editora Blücher, 2006. MORINAGA, C. M. Recuperação de Áreas Contaminadas. Um novo desafio para projetos paisagísticos. 2007. Dissertação (Mestrado) - Fauldade de Arquitetura e Urbanismo da Universidade de São Paulo, 2007.

NG, E. et al. A study on the cooling effects of greening in a high-density city: An experience from Hong Kong. Building and Environment, v. 47, n. 1, p. 256-271, 2012.

NOWAK, D. . Understanding the structure of urban forests. Journal of Forestry, v. 92, n. 10, p. 42-46, 1994. OKE, T. R. et al. Urban Climates. Cambridge: Cambridge University Press, 2017.

ORDÓÑEZ, C.; DUINKER, P. N. Assessing the vulnerability of urban forests to climate change. Environmental Reviews, v. 22, n. 3, p. 311-321, 2014.

PERERA, N. G. R.; EMMANUEL, M. P. R. A " Local Climate Zone " based approach to urban planning in Colombo, Sri Lanka. In: 9th International Conference on Urban Climate. Anais...Toulouse, 2015.

PONZONI, J.; SHIMABUKURO, Y. E.; KUPLICH, T. M. Sensoriamento remoto da vegetação. 2.ed.atual ed. São Paulo: Oficina de Textos, 2012.

PRATA-SHIMOMURA, A. R.; FERREIRA, A. T. Local Climate Zone Classification Adapted for Mapping Agricultural Areas in Metropolitan Areas. In: 10th International Conference on Urban Climate/ 14th Symposium on the Urban Environment. Anais...New York: American Meteorological Society, 2018 
QUEIROGA, E. F. Espaços livres, padrões morfológicos e apropriações públicas na metrópole paulistana. PARC : Pesquisa em Arquitetura e Construção, v. 7, p. 178-188, 2016.

RAO, P. K. Remote sensing of urban heat islands from an environmental satellite. Bulletin of the American Meteorological Society, n. 53, p. 647-648, 1972.

RCORETEAM. R: A language and environment for statistical computing.Vienna, 2018. Disponível em: $<$ https://www.r-project.org/>

REN, C. A review of the historical development of urban climatic map study. In: NG, E.; REN, C. (Eds.). . The Urban Climatic Map for Sustainable Urban Planning. London: Earthscan, 2015.

REN, C. et al. Local Climate Zone (LCZ) Classification Using the World Urban Database and Access Portal Tools (WUDAPT) Method: A Case Study in Wuhan and Hangzhou. The Fourth International Conference on Countermeasure to Urban Heat Islands (4th IC2UHI), n. May, p. 1-12, 2016.

ROTH, M. Review of urban climate research in (sub)tropical regions. International Journal of Climatology, n. 27, p. 1859-1873, 2007.

ROTH, M.; OKE, T. R.; EMERY, W. J. Satellite-derived urban heat islands from three coastal cities and the utilization of such data in urban climatology. International Journal of Remote Sensing, v. 10, n. 11, p. 16991720, 1989.

SABINS, F. F. Remote Sensing: principles and interpretation. $3^{\circ}$ ed. New York: W. H. Freeman and Company, 1996.

SALATA, F. et al. Relating microclimate, human thermal comfort and health during heat waves: An analysis of heat island mitigation strategies through a case study in an urban outdoor environment. Sustainable Cities and Society (30), p.79-96, 2017.

SANTAMOURIS, M.; KOLOKOTSA, D. (EDS.). Urban Climate Mitigation Techniques. London: Earthscan, 2016. SANTOS, M. Prefácio. In: LOMBARDO, M. A. Ilha de Calor nas Metrópoles. O exemplo de São Paulo. São Paulo: Hucitec, 1985.

SÃO PAULO. Lei Complementar $n^{\circ}$ 94, de 29 de maio de 1974. Dispõe sobre a Região Metropolitana da Grande São Paulo. Diário Oficial do Estado: São Paulo, SP, p. 3, 30 mai. 1974.

SÃO PAULO. Lei Complementar $n^{\circ}$ 1.139, de 16 de junho de 2011. Reorganiza a Região Metropolitana da 
Grande São Paulo, cria o respectivo Conselho de Desenvolvimento e dá providências correlatas. Diário Oficial do Estado: seção 1, São Paulo, SP, p.01, 17 jun. 2011.

SCARANO, M.; SOBRINO, J. A. On the relationship between the sky view factor and the land surface temperature derived by Landsat-8 images in Bari, Italy. International Journal of Remote Sensing, v. 36, n. 1920, p. 4820-4835, 2015.

SCHOWENGERDT, R. A. Remote Sensing: Models and Methods for Image Processing. $3^{\circ}$ edição ed. Burlington: Elsevier, 2007.

SHASHUA-BAR, L.; HOFFMAN, M. E. Vegetation as a climatic component in the design of an urban street: An empirical model for predicting the cooling effect of urban green areas with trees. Energy and Buildings, v. 31, n. 3, p. 221-235, 2000.

SHINZATO, P. Impacto da vegetação nos microclimas urbanos em função das interações solo-vegetaçãoatmosfera. Tese (Doutorado) - Faculdade de Arquitetura e Urbanismo, Universidade de São Paulo, São Paulo, 2014.

SIDIQUI, P.; HUETE, A.; DEVADAS, R. Spatio-temporal mapping and monitoring of Urban Heat Island patterns over Sydney, Australia using MODIS and Landsat-8. In: 4th International Workshop on Earth Observation and Remote Sensing Applications (EORSA). Anais... 2016.

SILLEOS, N. G. et al. Vegetation indices: Advances made in biomass estimation and vegetation monitoring in the last 30 years. Geocarto International, v. 21, n. 4, p. 21-28, 2006.

SOBRINO, J. A.; JULIEN, Y. Trend Analysis of Global MODIS-Terra Vegetation Indices and Land Surface Temperature Between 2000 and 2011. Selected Topics in Applied Earth Observations and Remote Sensing, IEEE Journal of, v. 6, n. 5, p. 2139-2145, 2013.

SOUSA, S. B. DE; FERREIRA, L. G. Análise da temperatura de superfície em ambientes urbanos: um estudo por meio de sensoriamento remoto no município de Goiânia, Goiás (2002-2011). Confins. Revista franco-brasileira de geografia, n. 15, p. 1-21, 2012.

SPIRN, A. W. O jardim de granito: a natureza no desenho da cidade. São Paulo: Editora da Universidade de São Paulo, 1995.

STEWART, I. D.; OKE, T. R. Local climate zones for urban temperature studies. Bulletin of the American 
Meteorological Society, v. 93, n. 12, p. 1879-1900, 2012.

STONE, B.; VARGO, J.; HABEEB, D. Managing climate change in cities: Will climate action plans work? Landscape and Urban Planning, v. 107, n. 3, p. 263-271, 2012.

TAHA, H. Urban climates and heat islands: albedo, evapotranspiration, and anthropogenic heat. Energy and Buildings, v. 25, n. 2, p. 99-103, 1997.

TAHA, H. et al. SUSTAIN: Heat Islands. n. 29, p. 1-65, 2014.

TAHA, H.; AKBARI, H.; ROSENFELD, A. Heat island and oasis effects of vegetative canopies: Micrometeorological field-measurements. Theoretical and Applied Climatology, v. 44, n. 2, p. 123-138, 1991. ULRICH, R. S. et al. Stress Recovery During Exposure To Natural and Urban Environments. Journal of Environmental Psychology, v. 11, p. 201-230, 1991.

UN/DESA - UNITED NATIONS DEPARTMENT OF ECONOMIC AND SOCIAL AFFAIRS, P. D. World Urbanization Prospects: The 2014 Revision, Highlights. Disponível em: <http://esa.un.org/unpd/wup/Highlights/WUP2014Highlights.pdf>. Acesso em: 20 mar. 2016.

VOOGT, J. A.; OKE, T. R. Thermal remote sensing of urban climates. Remote Sensing of Environment, v. 86, n. 3, p. 370-384, 2003.

WAN, Z. New refinements and validation of the collection-6 MODIS land-surface temperature/emissivity product. Remote Sensing of Environment, n.140, p.36-45, 2014.

WAN, Z. MODIS Land-Surface Temperature Algorithm Theoretical Basis Document ( LST ATBD ). Disponível em: <http://modis.gsfc.nasa.gov/data/atbd/atbd_mod11.pdf>. Acesso em: 25 nov. 2016.

WANG, J.; ZHAN, Q.; GUO, H. The morphology, dynamics and potential hotspots of land surface temperature at a local scale in urban areas. Remote Sensing, v. 8, n. 1, 2016.

WANG, X. Y. et al. The impact of heatwaves on mortality and emergency hospital admissions from nonexternal causes in Brisbane, Australia. Occupational and Environmental Medicine, v. 69, n. 3, p. 163-169, 2012.

WENG, Q. A remote sensing-GIS evaluation of urban expansion and its impact on surface temperature in the Zhujiang Delta, China. International Journal of Remote Sensing, v. 22, n. 10, p. 1999-2014, 2001. 
WENG, Q. Thermal infrared remote sensing for urban climate and environmental studies: Methods, applications, and trends. ISPRS Journal of Photogrammetry and Remote Sensing, v. 64, n. 4, p. 335-344, 2009. WENG, Q.; LU, D.; SCHUBRING, J. Estimation of land surface temperature-vegetation abundance relationship for urban heat island studies. Remote Sensing of Environment, v. 89, n. 4, p. 467-483, 2004.

WICKI, A.; PARLOW, E. Attribution of local climate zones using a multitemporal land use/land cover classification scheme. Journal of Applied Remote Sensing, v. 11, n. 2, 2017.

WMO; WHO. Heatwaves and Health: Guidance on Warning-System Development. [s.I: s.n.].

WONG, N. H.; CHEN, Y. Tropical Urban Heat Islands. Climate, buildings and greenery. Abingdon: Taylor and Francis, 2009.

WULF, A. A invenção da natureza: a vida e as descobertas de Alexander von Humboldt. São Paulo: Planeta, 2016.

YANG, X. Urban Remote Sensing: Monitoring, Synthesis and Modeling in the Urban Environment. Oxford: Wiley-Blackwell, 2011.

YENNETI, K. et al. Cooling Cities Strategies and Technologies to Mitigate Urban Heat Discussion Paper. Sydney: Cooperative Research Centres program, 2017

ZHAO, C. et al. Urban planning indicators, morphology and climate indicators: A case study for a north-south transect of Beijing, China. Building and Environment, v. 46, n. 5, p. 1174-1183, 2011.

ZHAO, C. Linking the Local Climate Zones and Land Surface Temperature To Investigate the Surface Urban Heat Island, a Case Study of San Antonio, Texas, U.S. ISPRS Annals of Photogrammetry, Remote Sensing and Spatial Information Sciences, v. IV-3, p. 277-283, 2018.

ZHENG, Y. et al. GIS-based mapping of Local Climate Zone in the high-density city of Hong Kong. Urban Climate, v.24, jun., 2018.

ZHOU, D. et al. Surface urban heat island in China's 32 major cities: Spatial patterns and drivers. Remote Sensing of Environment, v. 152, p. 51-61, 2014. 


\section{Apêndice 1. Cálculo estatístico}

O cálculo apresentado nesse apêndice foi desenvolvido pelo Centro de Estatística Aplicada do Instituto de Matemática e Estatística da Universidade de São Paulo (CEA-IME-USP) e apresentado no Relatório de Análise Estatística (CHIANN; SOARES; ALVES, 2018).

\section{Avaliação da inclinação com significância prática}

Para estudar as alterações ocorridas na temperatura e na vegetação ao longo do tempo foi realizado o ajuste de retas de regressão com o objetivo de capturar a tendência das séries temporais em estudo, permitindo, assim, avaliar a significância prática da inclinação obtida. Para isso, foram definidos valores considerados altos o suficiente para que as alterações observadas na temperatura e na vegetação ao longo do tempo possuam significância prática. Esses valores foram fornecidos pela pesquisadora, sendo consideradas significativas as temperaturas com mudança de $1^{\circ} \mathrm{C}^{47}$ e índices de vegetação com diferença de 0,05 unidades no período que corresponde aos anos de 2003 a 2017. Essa análise é realizada para cada um dos 143.992 pixels da área considerada.

Considerando $Y$ a variável resposta em estudo ( $T_{\text {sup }}$ Dia, $T_{\text {sup }}$ Noite, $E V I$ ou NDVI), a série $Y$ pode ser decomposta em três componentes: tendência $(\mathrm{T})$, sazonalidade $(\mathrm{S})$ e ruído (e), obtendo a seguinte forma:

$$
Y_{t}=T_{t}+S_{t}+e_{t}
$$

$\operatorname{com} \mathrm{t}=1,2, \ldots, \mathrm{n}$; sendo $\mathrm{n}=690$ para as variáveis de temperatura e $\mathrm{n}=345$ para os índices de vegetação (MORETTIN; TOLOI, 2006).

\footnotetext{
${ }^{47}$ Durante a consultoria junto ao CEA foi estabelecida significância prática para $\mathrm{T}_{\text {sup }}$ de $1^{\circ} \mathrm{C}$. Posteriormente a significância prática foi reduzida para $0,5^{\circ} \mathrm{C}$.
} 
Com o objetivo de avaliar apenas a variação da temperatura e da vegetação ao longo das $\mathrm{n}$ observações obtidas neste trabalho, considera-se a tendência como sendo linear, ou seja,

$\mathrm{T}_{\mathrm{t}}=\alpha+\beta \mathrm{t}$

Assim, a série $Y_{t}$ pode ser modelada da seguinte forma:

$$
\begin{aligned}
& Y_{t}=T_{t}+S_{t}+e_{t} \\
= & \alpha+\beta t+\varepsilon_{t},
\end{aligned}
$$

em que $\varepsilon_{\mathrm{t}}=\mathrm{S}_{\mathrm{t}}+\mathrm{e}_{\mathrm{t}}$ é o erro do modelo.

Assumindo erros independentes e homocedásticos, estimamos as retas $Y_{t}$ com a função:

$\widehat{Y}_{t}=\widehat{\alpha}+\widehat{\beta} t$

em que,

$\hat{\beta}=\frac{\sum_{\mathrm{i}=1}^{\mathrm{n}}(\mathrm{t}-\overline{\mathrm{t}})\left(\mathrm{Y}_{\mathrm{i}}-\overline{\mathrm{Y}}\right)}{\sum_{\mathrm{i}=1}^{\mathrm{n}}(\mathrm{t}-\overline{\mathrm{t}})^{2}} \quad$ e $\quad \widehat{\alpha}=\overline{\mathrm{Y}}-\widehat{\beta} \mathrm{t}$

sendo $\bar{Y}$ a média de $Y$ e $\bar{t}$ a média de $t, t=1,2, \ldots n$.

O erro padrão estimado de $\widehat{\beta}$ é dado por

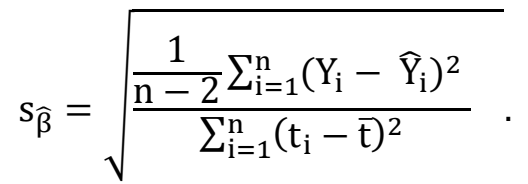

Usando esse resultado, construiu-se o intervalo de 95\% de confiança para a avaliação da significância prática da inclinação $\beta$ :

$$
\left[\widehat{\beta}-t_{c} * s_{\widehat{\beta}} ; \hat{\beta}+t_{c} * s_{\widehat{\beta}}\right]
$$

em que $\mathrm{P}\left(-\mathrm{t}_{\mathrm{c}}<t<\mathrm{t}_{\mathrm{c}}\right)=0,95, \mathrm{t} \sim \mathrm{t}_{\mathrm{n}-2}$ (Elian, 1988). 
Uma vez obtido o intervalo de confiança para $\beta$, multiplicamos seus limites inferior e superior por $\mathrm{n}, \mathrm{n}=690$ para temperatura e $\mathrm{n}=345$ para vegetação, e obtemos assim um intervalo de confiança para a variação ocorrida no período de 2003 a 2017. Se esse intervalo está inteiramente contido no conjunto dos reais $(-\infty,-1] \cup[1, \infty)$ para temperatura ou $(-\infty,-0,05] \cup[0,05, \infty)$ para vegetação, concluímos que a inclinação possui significância prática. Ou seja, se $\left(\widehat{\beta}-t_{c} * s_{\widehat{\beta}}\right) * 690>1$ para temperatura, houve aumento significativo da temperatura entre 2003 e 2017. Se $\left(\widehat{\beta}-\mathrm{t}_{\mathrm{c}} * \mathrm{~s}_{\widehat{\beta}}\right) * 690<-1$, houve redução significativa da temperatura entre 2003 e 2017, considerando o valor de 1ํㅡ fixado como critério de significância prática e confiança $\gamma$. Se $\left(\widehat{\beta}-\mathrm{t}_{\mathrm{c}} * \mathrm{~s}_{\widehat{\beta}}\right) * 345>$ 0,05, houve aumento significativo do índice de vegetação entre 2003 e 2017. Se $\left(\widehat{\beta}-\mathrm{t}_{\mathrm{c}} * \mathrm{~s}_{\widehat{\beta}}\right) * 345<-0,05$, houve redução significativa do índice de vegetação entre 2003 e 2017. 


\section{Apêndice 2. Correlações entre índices de vegetação e temperatura de superfície}

\begin{tabular}{|c|c|c|c|c|c|c|c|c|}
\hline \multicolumn{9}{|c|}{ Resolução Espacial: $1 \mathrm{~km}$} \\
\hline & TDxNDVI & TDxNDVI (>50\%) & TDXEVI & TDXEVI $(>50 \%)$ & TNXNDVI & TNXNDVI $(>50 \%)$ & TNXEVI & TNXEVI $(>50 \%)$ \\
\hline $\mathrm{CH} .0203$ & 0,92 & 0,92 & 0,87 & 0,87 & 0,85 & 0,85 & 0,86 & 0,86 \\
\hline SC.03 & 0,92 & 0,92 & 0,86 & 0,86 & 0,63 & 0,63 & 0,68 & 0,68 \\
\hline $\mathrm{CH} .0304$ & 0,91 & 0,91 & 0,86 & 0,86 & 0,81 & 0,81 & 0,81 & 0,81 \\
\hline SC.04 & 0,93 & 0,93 & 0,87 & 0,87 & 0,68 & 0,68 & 0,71 & 0,71 \\
\hline $\mathrm{CH} .0405$ & 0,92 & 0,92 & 0,88 & 0,87 & 0,85 & 0,86 & 0,85 & 0,85 \\
\hline SC.05 & 0,92 & 0,92 & 0,85 & 0,85 & 0,65 & 0,64 & 0,68 & 0,68 \\
\hline $\mathrm{CH} .0506$ & 0,91 & 0,91 & 0,85 & 0,85 & 0,83 & 0,84 & 0,82 & 0,82 \\
\hline SC.06 & 0,93 & 0,93 & 0,87 & 0,87 & 0,61 & 0,61 & 0,65 & 0,65 \\
\hline $\mathrm{CH} .0607$ & 0,91 & 0,91 & 0,85 & 0,84 & 0,84 & 0,84 & 0,85 & 0,85 \\
\hline SC. 07 & 0,92 & 0,92 & 0,85 & 0,85 & 0,61 & 0,61 & 0,63 & 0,63 \\
\hline $\mathrm{CH} .0708$ & 0,9 & 0,9 & 0,86 & 0,86 & 0,81 & 0,81 & 0,81 & 0,81 \\
\hline SC.08 & 0,93 & 0,93 & 0,86 & 0,86 & 0,64 & 0,64 & 0,68 & 0,68 \\
\hline CH.0809 & 0,91 & 0,9 & 0,85 & 0,85 & 0,84 & 0,86 & 0,82 & 0,84 \\
\hline SC.09 & 0,92 & 0,92 & 0,85 & 0,85 & 0,72 & 0,72 & 0,75 & 0,75 \\
\hline CH.0910 & 0,91 & 0,91 & 0,87 & 0,87 & 0,81 & 0,81 & 0,81 & 0,81 \\
\hline SC. 10 & 0,93 & 0,93 & 0,87 & 0,87 & 0,62 & 0,61 & 0,65 & 0,64 \\
\hline CH.1011 & 0,9 & 0,9 & 0,83 & 0,84 & 0,81 & 0,8 & 0,77 & 0,78 \\
\hline SC.11 & 0,92 & 0,92 & 0,84 & 0,84 & 0,6 & 0,59 & 0,64 & 0,63 \\
\hline CH.1112 & 0,9 & 0,9 & 0,83 & 0,83 & 0,83 & 0,82 & 0,82 & 0,81 \\
\hline SC. 12 & 0,92 & 0,92 & 0,85 & 0,85 & 0,73 & 0,73 & 0,76 & 0,76 \\
\hline CH.1213 & 0,91 & 0,92 & 0,82 & 0,82 & 0,81 & 0,81 & 0,8 & 0,8 \\
\hline SC.13 & 0,93 & 0,93 & 0,85 & 0,85 & 0,68 & 0,68 & 0,72 & 0,71 \\
\hline CH.1314 & 0,91 & 0,91 & 0,86 & 0,86 & 0,83 & 0,83 & 0,84 & 0,84 \\
\hline SC.14 & 0,93 & 0,93 & 0,86 & 0,86 & 0,67 & 0,67 & 0,72 & 0,72 \\
\hline CH.1415 & 0,91 & 0,9 & 0,86 & 0,85 & 0,82 & 0,83 & 0,83 & 0,83 \\
\hline SC. 15 & 0,93 & 0,93 & 0,87 & 0,87 & 0,67 & 0,68 & 0,71 & 0,71 \\
\hline CH.1516 & 0,92 & 0,93 & 0,85 & 0,86 & 0,79 & 0,81 & 0,77 & 0,79 \\
\hline SC. 16 & 0,92 & 0,92 & 0,87 & 0,87 & 0,67 & 0,66 & 0,71 & 0,7 \\
\hline CH.1617 & 0,91 & 0,91 & 0,86 & 0,86 & 0,82 & 0,82 & 0,81 & 0,81 \\
\hline SC.17 & 0,92 & 0,92 & 0,86 & 0,86 & 0,67 & 0,68 & 0,71 & 0,71 \\
\hline
\end{tabular}

CH. Estação chuvosa | SC. Estação Seca | TD. Temperatura superficial diurna | TN. Temperatura superficial noturna | $>50 \%$. Médias calculadas com imagens contendo mais de $50 \%$ de pixels válidos

\begin{tabular}{|c|c|c|c|c|c|c|c|c|}
\hline \multicolumn{9}{|c|}{ Resolução Espacial: 250m } \\
\hline & TDXNDVI & TDxNDVI $(50 \%)$ & TDXEVI & TDXEVI (50\%) & TNXNDVI & TNXNDVI $(50 \%)$ & TNXEVI & TNXEVI $(50 \%)$ \\
\hline $\mathrm{CHO2O3}$ & 0,9 & 0,9 & 0,84 & 0,84 & 0,82 & 0,82 & 0,82 & 0,83 \\
\hline $\mathrm{SCO} 3$ & 0,89 & 0,89 & 0,83 & 0,83 & 0,61 & 0,61 & 0,64 & 0,64 \\
\hline $\mathrm{CH} 0304$ & 0,88 & 0,88 & 0,82 & 0,83 & 0,77 & 0,77 & 0,76 & 0,76 \\
\hline $\mathrm{SCO} 4$ & 0,9 & 0,9 & 0,83 & 0,83 & 0,66 & 0,66 & 0,67 & 0,67 \\
\hline $\mathrm{CH} 0405$ & 0,9 & 0,9 & 0,84 & 0,84 & 0,82 & 0,82 & 0,8 & 0,81 \\
\hline $\mathrm{SCO5}$ & 0,89 & 0,89 & 0,82 & 0,82 & 0,62 & 0,61 & 0,64 & 0,64 \\
\hline $\mathrm{CH} 0506$ & 0,89 & 0,89 & 0,82 & 0,8 & 0,8 & 0,8 & 0,78 & 0,77 \\
\hline $\mathrm{sc06}$ & 0,9 & 0,9 & 0,84 & 0,84 & 0,59 & 0,59 & 0,62 & 0,62 \\
\hline $\mathrm{CH} 0607$ & 0,89 & 0,89 & 0,82 & 0,82 & 0,81 & 0,81 & 0,81 & 0,81 \\
\hline SC07 & 0,89 & 0,89 & 0,82 & 0,82 & 0,59 & 0,59 & 0,6 & 0,6 \\
\hline $\mathrm{CH} 0708$ & 0,88 & 0,88 & 0,83 & 0,83 & 0,78 & 0,78 & 0,77 & 0,77 \\
\hline $\mathrm{SCO} 8$ & 0,9 & 0,9 & 0,82 & 0,82 & 0,61 & 0,61 & 0,64 & 0,64 \\
\hline $\mathrm{CH} 0809$ & 0,88 & 0,89 & 0,82 & 0,82 & 0,81 & 0,82 & 0,78 & 0,8 \\
\hline $\mathrm{SCO9}$ & 0,9 & 0,9 & 0,82 & 0,82 & 0,69 & 0,69 & 0,71 & 0,71 \\
\hline $\mathrm{CH} 0910$ & 0,88 & 0,89 & 0,84 & 0,84 & 0,78 & 0,78 & 0,77 & 0,76 \\
\hline SC10 & 0,9 & 0,9 & 0,83 & 0,84 & 0,59 & 0,57 & 0,61 & 0,6 \\
\hline $\mathrm{CH} 1011$ & 0,88 & 0,88 & 0,8 & 0,8 & 0,78 & 0,77 & 0,77 & 0,73 \\
\hline SC11 & 0,89 & 0,89 & 0,81 & 0,81 & 0,57 & 0,56 & 0,6 & 0,59 \\
\hline CH1112 & 0,88 & 0,88 & 0,8 & 0,8 & 0,79 & 0,78 & 0,78 & 0,77 \\
\hline SC12 & 0,89 & 0,89 & 0,82 & 0,82 & 0,7 & 0,7 & 0,72 & 0,72 \\
\hline $\mathrm{CH} 1213$ & 0,89 & 0,89 & 0,79 & 0,79 & 0,79 & 0,78 & 0,76 & 0,76 \\
\hline SC13 & 0,9 & 0,9 & 0,81 & 0,82 & 0,66 & 0,66 & 0,68 & 0,68 \\
\hline $\mathrm{CH} 1314$ & 0,88 & 0,88 & 0,82 & 0,82 & 0,8 & 0,8 & 0,79 & 0,8 \\
\hline SC14 & 0,9 & 0,9 & 0,83 & 0,83 & 0,64 & 0,64 & 0,68 & 0,68 \\
\hline CH1415 & 0,89 & 0,88 & 0,83 & 0,82 & 0,8 & 0,8 & 0,8 & 0,8 \\
\hline SC15 & 0,9 & 0,9 & 0,83 & 0,83 & 0,64 & 0,63 & 0,67 & 0,66 \\
\hline CH1516 & 0,9 & 0,9 & 0,82 & 0,82 & 0,76 & 0,79 & 0,74 & 0,75 \\
\hline SC16 & 0,89 & 0,89 & 0,83 & 0,83 & 0,63 & 0,63 & 0,66 & 0,66 \\
\hline $\mathrm{CH} 1617$ & 0,89 & 0,89 & 0,83 & 0,84 & 0,79 & 0,78 & 0,77 & 0,77 \\
\hline SC17 & 0,89 & 0,89 & 0,82 & 0,82 & 0,64 & 0,63 & 0,66 & 0,66 \\
\hline
\end{tabular}

CH. Estação chuvosa | SC. Estação Seca | TD. Temperatura superficial diurna | TN. Temperatura superficial noturna | >50\%. Médias calculadas com imagens contendo mais de $50 \%$ de pixels válidos 
